UNIVERSIDADE DE SÃO PAULO

Faculdade de Educação

CAROLINA PICCHETTI NASCIMENTO

A organização do ensino e a formação do pensamento estético-artístico na teoria histórico-cultural.

São Paulo

2010 


\section{CAROLINA PICCHETTI NASCIMENTO}

\section{A organização do ensino e a formação do pensamento estético-artístico na}

teoria histórico-cultural.

Dissertação apresentada à Banca Examinadora da Comissão de Pós-Graduação da Faculdade de Educação da Universidade de São Paulo, como exigência parcial à obtenção do título de Mestre em Educação (Área de Ensino de Ciências e Matemática), sob a orientação do Prof. Dr. Manoel Oriosvaldo de Moura.

São Paulo 
Autorizo a reprodução e divulgação total ou parcial deste trabalho, por qualquer meio convencional ou eletrônico, para fins de estudo e pesquisa, desde que citada a fonte.

Catalogação na Publicação

Serviço de Biblioteca e Documentação

Faculdade de Educação da Universidade de São Paulo

372.7 Nascimento, Carolina Picchetti

N244o A organização do ensino e a formação do pensamento estético-artístico na teoria histórico-cultural / Carolina Picchetti Nascimento ; orientação

Manoel Oriosvaldo de Moura. São Paulo : s.n., 2010.

249 p. : il.

Dissertação (Mestrado - Programa de Pós-Graduação em Educação. Área de Concentração : Ensino de Ciências e Matemática) - - Faculdade de Educação da Universidade de São Paulo.

1. Vygotsky, Lev Semenovitch, 1896-1934 2. Educação física escolar 3. Ensino - Atividade I. Moura, Manoel Oriosvaldo de, orient. 


\section{FOLHA DE APROVAÇÃO}

\section{Carolina Picchetti Nascimento}

A organização do ensino e a formação do pensamento estético-artístico na teoria histórico-cultural.

Dissertação apresentada à Banca Examinadora da Comissão de Pós-Graduação da Faculdade de Educação da Universidade de São Paulo, como exigência parcial à obtenção do título de Mestre em Educação (Área de Ensino de Ciências e Matemática), sob a orientação do Prof. Dr. Manoel Oriosvaldo de Moura.

Aprovado em:

\section{BANCA EXAMINADORA}

Prof. Dr. Manoel Oriosvaldo de Moura

Instituição: FEUSP

Assinatura:

Prof. Dra. Elaine Sampaio Araujo

Instituição: FFLCRP-USP

Assinatura:

Prof. Dra. Sonia Mari Shima Barroco

Instituição: UEM

Assinatura: 


\section{AGRADECIMENTOS}

Aos meus "parceiros mais capazes", pessoas que criaram de forma direta ou indireta as circunstâncias para os meus processos de apropriação do mundo e objetivação nele. Às pessoas e/ou coletivos que desempenharam um papel fundamental em minha vida e contribuíram para meu processo de desenvolvimento nas diversas esferas que dela fazem parte.

Aos meus pais, Popito e Mamita, que indiretamente me fizeram ter consciência da profunda injustiça humana de nossa presente sociedade e que, de modo mais direto, me fizeram desejar, ainda bem pequenina, construir uma nova sociedade, com relações humanas mais justas para todos.

Ao Luiz (Dantas), professor que me ajudou em minha formação de ser professora e com quem compartilho as tarefas de pensar sobre o ensino da educação física.

Ao Ori, que nos erradia com a sua profunda convicção nas possibilidades da educação para a construção de uma sociedade humanamente mais justa e que nos demonstra a cada dia o que é ser educador em todas as esferas da vida. A ele, que da forma mais ampla possível, ajudou a criar as circunstâncias para o meu processo de formação como pesquisadora.

Aos grupos de estudo e pesquisa GEPAPe e LIEPPE, que igualmente, enquanto espaços vivos, colocaram e colocam em movimento meus estudos sobre a teoria histórico-cultural. Em especial àqueles que acompanharam de perto a escrita dessa dissertação e com quem compartilhamos sonhos e temos ótimos debates: Malu, Elaine e Flávia.

Ao coletivo de educadores de uma escola pública da prefeitura de São Paulo, com quem aprendi muito do que é ser uma educadora.

Ao coletivo de professores de educação física com quem trabalhei num projeto que desenvolvemos em uma creche da prefeitura de São Paulo (2003-2005) e com quem pude iniciar muitas reflexões sobre a organização do ensino da educação física. 
Aos meus amigos, companheiros de vida, que me fizeram e fazem vivenciar a alegria de boas e sinceras relações entre as pessoas:

Às amigas “cumadis”: Ciça, Crisoca, Lelé e Marcita.

Aos amigos da “70 turma”: lá se vão bons 10 anos!

Aos amigos parentes, cuidadores da irmãzinha caçula: Dã e Aninha.

Ao amigo, mais que companheirinho: Brenovski. 
Carolina Picchetti NASCIMENTO. A organização do ensino e a formação do pensamento estético-artístico na teoria histórico-cultural. 2010. 249f. Dissertação (mestrado). Faculdade de Educação, Universidade de São Paulo, São Paulo, 2010.

\section{RESUMO}

Compreender o processo de organização do ensino para o desenvolvimento do pensamento teórico constituiu-se no objetivo central desta pesquisa. Com base nos estudos da teoria histórico-cultural entendemos ser possível e necessário organizar o ensino de modo que o mesmo seja maximamente favorável ao desenvolvimento do pensamento teórico dos educandos. Considerando que o pensamento teórico em geral forma-se a partir de um objeto concreto, procuramos investigar o processo de organização do ensino para a formação do pensamento teórico a partir de uma manifestação particular desse tipo de pensamento: o pensamento teórico no campo da arte ou o pensamento estético-artístico. Procuramos demonstrar ao longo do trabalho a possibilidade de vincular esse tipo de pensamento ao ensino da educação física, disciplina que tem como objetivo organizar a apropriação dos significados das atividades da cultura corporal, dentre eles o estético-artístico. Organizamos a presente pesquisa como uma investigação bibliográfico-conceitual (em que analisamos o papel da arte no processo de formação humana; a atividade de estudo e a formação do pensamento teórico; o processo de organização do ensino e alguns princípios didáticos presentes na teoria histórico-cultural) e uma investigação didático-experimental (em que criamos as condições para a análise do processo de organização do ensino para a formação do pensamento teórico). Nosso experimento didático, instrumento investigativo para a análise do trabalho pedagógico, foi constituído pela elaboração, e posterior realização com estudantes do $4^{\mathrm{o}}$ ano do ensino fundamental I, de uma unidade didática sobre o circo. A partir da explicitação da unidade fundamental do circo (a composição de cenas) e das suas abstrações conceituais (os elementos de criação das cenas), organizamos o ensino buscando garantir que os estudantes tivessem momentos diretos de trabalho com os conceitos, isto é, que agissem mediados pelos conceitos. Assim, a exposição das sínteses conceituais para os estudantes, o planejamento orientado da criação das cenas e a análise das cenas criadas mediadas pelos conceitos teóricos permitiram que os educandos trabalhassem com o modo geral de ação do artista circense, ou seja, o modo como o artista abstrai os elementos da realidade e os sintetiza em uma nova realidade ou no seu objeto artístico. Avaliamos que esse percurso de aprendizagem e essa forma de organização do ensino possibilitam ao sujeito a apropriação de instrumentos para abstrair os elementos essenciais de uma dada realidade artística, bem como para criar conscientemente seu próprio objeto artístico, o que lhe permite uma maior aproximação da arte, um maior conhecimento desse tipo de atividade humano-genérica. Por fim, a pesquisa nos indica para uma real possibilidade de construção de um modo geral de ação docente ou uma base teórico-metodológica para a organização do ensino referenciada na teoria histórico-cultural.

Palavras-chave: teoria histórico-cultural; pensamento teórico; atividade de ensino; ensino da educação física; atividade orientadora de ensino. 
Carolina Picchetti NASCIMENTO. The organization of teaching and the formation of aesthetic-artistic thinking in the cultural-historical theory. 2010. 249f. Dissertação (mestrado). Faculdade de Educação, Universidade de São Paulo, São Paulo, 2010.

\begin{abstract}
Understanding the organization of teaching for the development of theoretical thinking constitutes the main goal of this research. Based on the cultural-historical theory we assume that it is possible and even necessary to organize teaching in order to contribute to student's theoretical thinking development. Considering that theoretical thinking always develops from a concrete object, in our research we sought to investigate the teaching organization process for the formation of theoretical thinking from a particular point of view: the aesthetic-artistic thinking, which is the theoretical thinking present in art. Throughout this work we have tried to demonstrate the possibility of linking this type of thinking to physical education - a school subject that aims to organize the appropriation of the meanings of body culture activities, and among those meanings is the aesthetic-artistic. We organized this present research as a conceptual-bibliographical investigation (in which we analyzed the role of art in human development; the studying activity and the formation of theoretical thinking; the process of organizing teaching and some didactic principles present in cultural-historical theory) and as a didactic-experimental investigation (in which we created the conditions to analyze the process of organizing teaching for the development of theoretical thinking). Our teaching experiment, which is an investigative instrument to analyze pedagogical work, was formed by the preparation and subsequent implementation, with students in 4th year of elementary school, of a didactic unit about the circus. From the explicitness of the fundamental unity of circus (to compose the scenes) and its conceptual abstractions (the elements that create the scenes), we organized teaching seeking to ensure that students had moments of direct work with the concepts, that is, that they could act mediated by them. Thus, exposure of students to conceptual overviews, the guided planning of the scenes' making and the analysis of the created scenes mediated by theoretical concepts allowed the students to work with the general way of action of the circus artist, which is how the artist abstracts the elements of reality and summarizes them in a new reality or in his artistic object. We assess that this learning course and this form of organizing teaching enable the subject to appropriate instruments, both to abstract the essential elements of a given artistic reality, as to consciously create its own artistic object, which allows a closer approximation of art, a greater knowledge of this type of human-generic activity. Finally, the research points us to a real possibility of constructing a general mode of teaching action or a theoretical and methodological basis for the organization of teaching, referenced in the cultural- historical theory.
\end{abstract}

Keywords: cultural-historical theory, theoretical thinking, teaching activity, physical education teaching; 


\section{LISTA DE QUADROS E FIGURAS}

Quadro 1: Tipos de pensamentos e suas características na educação física.............................28

Quadro 2: Ações dos educandos e ações dos educadores na atividade pedagógica

(referenciado em RUBTSOV, 1996).

Quadro 3: Formas de colaboração para os processos de desenvolvimento............................108

Quadro 4: Resumo dos tópicos trabalhados nas aulas do experimento didático....................124

Quadro 5: Os episódios de ensino e de aprendizagem e as unidades conceituais de análise. 134

Quadro 6: O processo de explicitação da unidade fundamental do circo..............................138

Quadro 7: As abstrações conceituais para o trabalho de ensino com a atividade circense....141

Quadro 8: Etapas para a organização do ensino pelo educador. .......................................... 143

Quadro 9: Planejamento geral da unidade didática do circo. .............................................. 144

Quadro 10: Tarefas de aprendizagem, ações docentes e ações discentes na unidade didática do circo. 146

Quadro 11: Os elementos componentes dos episódios de ensino e aprendizagem ..... 149

Figura 1: As relações da criatividade na atividade artística. 129

Figura 2: Síntese da atividade circense a partir da sua unidade fundamental. 139 


\section{SUMÁRIO}

MOTIVOS DA PESQUISA E O PROCESSO DE ELABORAÇÃO DO OBJETO DE INVESTIGAÇÃO

1. INTRODUÇÃO AO PROBLEMA DA FORMAÇÃO DO PENSAMENTO ESTÉTICO-

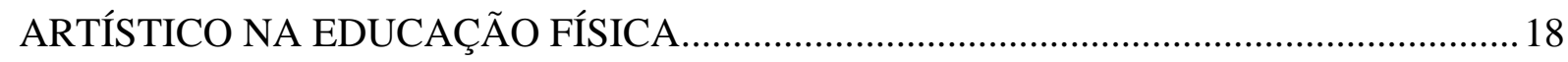

1.1 Sobre o objeto a ser apropriado no ensino da educação física. ........................................ 22

1.2 Sobre o estudo do pensamento estético-artístico............................................................26

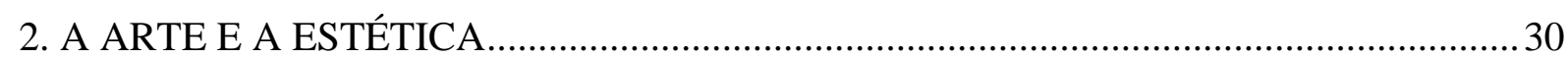

2.1 O papel do trabalho e da atividade no processo de ontogênese humana e sua relação com a

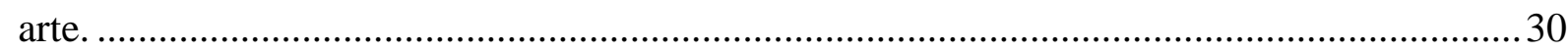

$2.2 \mathrm{O}$ objeto, a conduta, a Atividade e a formação dos sentidos humanos............................... 35

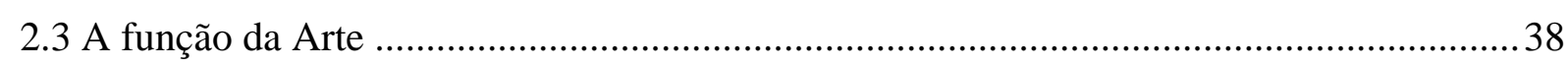

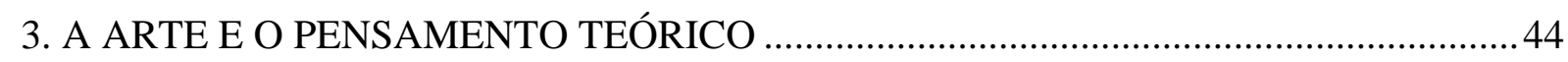

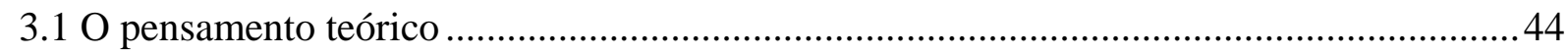

3.2 O processo de formação de conceitos............................................................................. 51

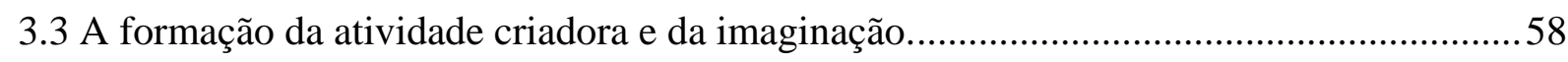

3.4 A arte e o pensamento teórico: o pensamento estético-artístico.........................................64

4. ELEMENTOS PARA A ORGANIZAÇÃO DO ENSINO E A FORMAÇÃO DO

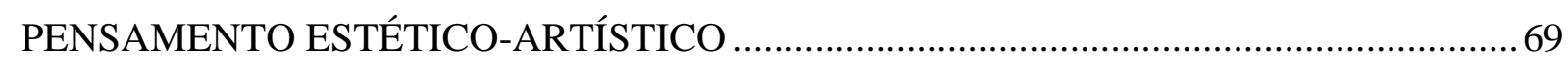

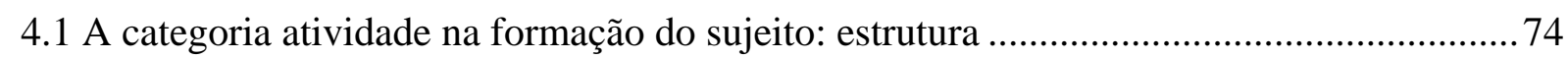

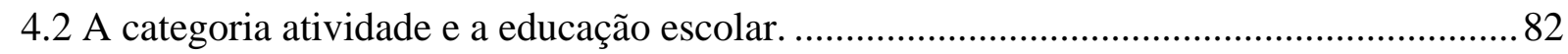

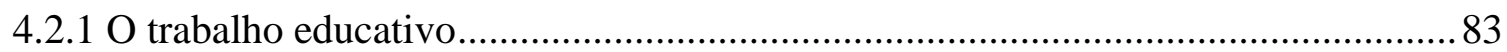

4.3 A organização do trabalho educativo: a Atividade Orientadora de Ensino......................... 89

4.3.1 A atividade de estudo e as ações de aprendizagem ............................................. 97

4.4 Princípios didáticos na psicologia histórico-cultural..................................................... 100

5. CAMINHOS METODOLÓGICOS: AS AÇÕES DO PESQUISADOR............................116

5.1 O processo de organização do experimento didático. ....................................................117

5.2 O processo de organização da análise dos dados .......................................................... 122 
5.2.1 As unidades conceituais de análise.

6. OS DADOS E AS ANÁLISES: AS ABSTRAÇÕES E AS SÍNTESES DA PESQUISA.136

6.1 O processo de organização da unidade de ensino do circo. 136

6.1.1 A unidade fundamental do objeto circo. 136

6.1.2 O plano de ensino 142

6.2 Análise dos Episódios de Ensino e aprendizagem 149

6.2.1 Os Episódios de Ensino 150

6.2.2 Os Episódios de Aprendizagem. 181

7. AS SÍNTESES DA PESQUISA: O PROCESSO DE ORGANIZAÇÃO DO ENSINO PARA A FORMAÇÃO DO PENSAMENTO TEÓRICO 225

8. REFERÊNCIAS BIBLIOGRÁFICAS 237

ANEXOS 243 
"Educar es depositar en cada hombre toda la obra humana que le ha antecedido; es hacer a cada hombre resumen del mundo viviente hasta el día en que vive”

José Martí

\section{MOTIVOS DA PESQUISA E O PROCESSO DE ELABORAÇÃO DO OBJETO DE INVESTIGAÇÃO}

Vivemos em um momento da história da humanidade em que as análises conjunturais mais otimistas da sociedade e da educação são, em última instância, análises pessimistas. Dizer isto não significa, necessariamente, assumir uma postura derrotista ou mesmo “desesperançosa”. Trata-se da compreensão de que vivemos, infelizmente, cada vez mais distantes de um modelo de sociedade referenciado nos princípios do comunismo - da construção de uma sociedade e, portanto, de uma educação, que tenha como principal referência o humano - e cada vez mais próximos da ribanceira da barbárie, do enraizamento da mercadoria em todas as esferas da vida. É diante desse quadro que devemos pensar nas reais condições da educação e da educação escolar em nosso tempo.

Apesar de acreditarmos, em termos gerais, que a escola vem servindo cada vez mais como contribuidora para a manutenção de nossa sociedade, para cumprir a produtividade desejada no modelo atual, que como diz Frigotto (2001), refere-se, entre outras coisas, no prolongamento do tempo de escolarização, já que não há emprego para todos e, assim, na ampliação do tempo de improdutividade dos sujeitos, pensamos que há um aspecto (e talvez apenas um) em que a escola ainda possa, e deva, contribuir para uma humanização não alienada - ou menos alienada - dos sujeitos. Esse aspecto deve vincular-se a uma transformação mais ampla da sociedade, pois “[...] uma reformulação significativa da educação é inconcebível sem a correspondente transformação do quadro social no qual as práticas educacionais da sociedade devem cumprir as suas vitais e historicamente importantes funções de mudança” (MÈZÀROS, p. 25, 2005).

A função humanizadora da escola vem sendo cada vez mais associada à possibilidade que ela nos dá de vivenciar relações democráticas, utilizando o diálogo como forma central para a resolução de conflitos e convivendo e respeitando as diferenças entre os sujeitos. Defende-se a idéia de que a escola deva ser essa outra referência de humanidade para as crianças e adultos que dela tomam parte. 
Ainda que bastante difundida e que obtenha um ou vários resultados positivos, essa perspectiva obterá sempre resultados pontuais ou particulares. Certamente causará um impacto bastante grande na vida de um indivíduo, para uma criança que vivencie determinadas relações mais democráticas ou mais dialógicas entre as pessoas. Não discordamos disso e, inclusive, compartilhamos do princípio geral de termos relações humanas mais democráticas e solidárias nas múltiplas esferas da vida. Mas acaso são essas vivências democráticas, dialógicas e pacifistas nas escolas, em comunidades ou em projetos sociais (e ainda que sejam vivências muito fortes para os sujeitos), as que poderão transformar as estruturas de desigualdade, de intolerância e de violência em nossa sociedade? Ou em outros termos, podemos dizer que essas estruturas todas são originadas pelos sujeitos individualmente e que, portanto, devemos ir transformando esses sujeitos para que posteriormente as estruturas mesmas se transformem? E se assim o for - e parafraseando Marx: quem será o sujeito que irá transformar todos os demais sujeitos?

Nossa crítica a esse modelo aparentemente tão progressista de ensino pode parecer manifestar uma postura derrotista e de desistência da possibilidade mais ampla de transformação social e da possibilidade mais específica de contribuição da escola para essa transformação. Ou mesmo, uma descrença na necessidade do exercício de relações humanas verdadeiramente humanizadas. Entretanto, o ponto de debate, aqui, refere-se à função social da escola. Assim, ainda que possamos e devemos lutar para que as crianças vivenciem relações verdadeiramente humanas na escola, vivenciar tais relações não pode ser tomado como a finalidade do trabalho escolar.

Como dissemos, de fato cremos que vivemos em um momento em que as condições para as transformações mais amplas da sociedade não sejam favoráveis. Para mudar de forma mais ampla e efetiva a sociedade, é preciso mudar a estrutura mesma dessa sociedade (o que só é possível via revolução social) e é nessa afirmativa que residem os limites e as potencialidades da escola e da educação como contribuidoras desse processo.

Afirmamos, anteriormente, que entediamos haver um aspecto em que a escola ainda pudesse (e devesse) contribuir para uma humanização não alienada (ou menos alienada) dos sujeitos. Como mencionamos, esse aspecto não reside na vivência de relações mais democráticas; não reside, no fundamental, na criação de uma escola "paralela” a sociedade, de uma "ilha” de relações verdadeiramente humanas, o que de todo modo é impossível. Para nós, essa contribuição da escola reside na concretização da função historicamente atribuída a ela, mas que vem sendo cada vez mais omitida ou secundarizada e que nos parece estar brilhantemente sintetizada na frase de José Marti, escolhida como epígrafe deste trabalho: 
"Educar es depositar en cada hombre toda la obra humana que le ha antecedido; es hacer a cada hombre resumen del mundo viviente hasta el día en que vive”.

O aspecto fundamental, portanto, em que a escola pode efetivamente dar a sua contribuição na busca de uma educação que enriqueça os indivíduos de necessidades humanas e humanizadoras, reside no seu compromisso em garantir que as novas gerações se apropriem dos conhecimentos científicos ou teóricos historicamente produzidos.

Fora dessa função, fora do compromisso de garantir que as novas gerações se apropriem das máximas possibilidades de conhecimento sobre o mundo, produzidos nas diversas esferas da vida, a escola ficará fadada a poucas ou mínimas contribuições para a formação de sujeitos cuja humanidade possa se dar de modo verdadeiramente humanizado.

É justamente nessa direção que vemos a contribuição da teoria histórico-cultural para pensarmos o ensino escolar.

A fundamentação no materialismo histórico-dialético, em termos gerais, e nas teorias que tratam mais diretamente das questões pedagógicas (particularmente a teoria históricocultural) nos conduz a analisar cada disciplina - em particular - a partir de uma finalidade em comum. Qualquer disciplina busca, através de seus conceitos historicamente elaborados, contribuir para que os educandos possam melhor conhecer a realidade social em que vivem; que se apropriem de novas formas de agir no mundo. Quaisquer disciplinas devem contribuir para o desenvolvimento das formas de conduta culturais mais elaboradas que a humanidade já criou, em especial, contribuir para a formação do pensamento teórico nos estudantes, o que exige que elas tenham como objeto de ensino as máximas elaborações produzidas pela humanidade, ou em outras palavras, as “objetivações genéricas para-si” (DUARTE, 1993; HELLER, 1991 e 2008).

A vinculação da disciplina de educação física, área de nossa formação como educadores, com essa perspectiva teórica deve encontrar justificativa no seu objeto de ensino e de aprendizagem. Quais seriam as objetivações humano-genéricas no campo da educação física ou quais os seus objetos de ensino e de aprendizagem? Quais os modos de organizarmos o ensino para que essas objetivações possam ser apropriadas pelos estudantes? Quais as formas de conduta (ou as funções psíquicas superiores), que o ensino da educação física pode contribuir? As respostas a essas questões, como dissemos, estão vinculadas ao entendimento de qual seja o objeto dessa disciplina.

Uma primeira resposta a essa questão é considerar como objeto da educação física os movimentos (ações motoras) e as capacidades físicas. Uma vez estabelecido este objeto, estabelece-se que o objetivo da educação física seja o de ensinar as crianças a se 
movimentarem melhor e/ou de fazê-las adquirir um melhor condicionamento físico. Essa perspectiva, bastante vinculada a uma concepção biologicista da educação física e de seu ensino e que abarca diferentes correntes pedagógicas da área ${ }^{1}$, procurou ser superada por outras concepções pedagógicas que viam como objeto de ensino da educação física não o corpo em si mesmo, ou o corpo fragmentado em seus elementos (capacidades físicas e habilidades motoras), mas as manifestações corporais culturalmente produzidas. Neste sentido, e de forma bastante ampla, elege-se a "cultura corporal" como objeto de ensino da educação física.

O termo cultura corporal, hoje amplamente difundido no meio da educação física escolar, foi desenvolvido na década de 90 por autores vinculados à perspectiva crítica na área da educação e da educação física e como uma tentativa de superar, justamente, as concepções pedagógicas biologicistas predominantes na área. Essa nova concepção caminha, de fato, em direção à valorização da cultura e do conhecimento na prática pedagógica da educação física.

Entretanto, o estabelecimento de quais sejam os conhecimentos dessa área e, mais amplamente, do desenvolvimento curricular da educação física, parece não ter conseguido se concretizar plenamente. Ao desenvolver quais os conhecimentos a serem ensinados e aprendidos a partir das manifestações corporais, ou da “cultural corporal”, pode-se ficar, ainda, na seguinte contradição: reduzir as manifestações da cultura corporal aos movimentos e às capacidades físicas que dela fazem parte (mantendo como objeto real da disciplina o mesmo que havia sido alvo de críticas e negação anteriormente); ou, realizar uma listagem de manifestações que serão vivenciadas, sem, contudo, conseguir explicitar os conhecimentos que devem ser apropriados pelos educandos em cada uma dessas manifestações.

Deste modo, assumir simplesmente a "cultura corporal” como objeto de ensino da educação física não soluciona nem a questão de seu objeto propriamente dito, nem dos processos de organização de seu ensino. É preciso pensar a cultura corporal em termos teórico-metodológico, isto é, em seus aspectos pedagógico e didático, tarefa esboçada ou iniciada pelo Coletivo de Autores (1992) que via como finalidade da educação física a contribuição para que os educandos tivessem um maior conhecimento da realidade social historicamente produzida, particularmente daquela realidade relacionada às atividades da cultura corporal.

\footnotetext{
${ }^{1}$ Como principais correntes, citamos: desenvolvimentista, psico-motricidade, esportivização.
} 
Dizer apenas isso é, ainda, extremamente genérico e pode nos levar ao mesmo erro ou reducionismo já mencionado anteriormente quando da definição da educação física a partir das manifestações corporais.

Uma primeira questão que podemos colocar é a de que qualquer realidade que possamos pensar, qualquer prática social, é constituída por uma infinidade de elementos. Sendo assim, se faz necessário (e essa é uma tarefa do educador) encontrar nessa realidade “caótica” os conhecimentos historicamente produzidos e relevantes de serem trabalhados na atividade escolar (as sínteses e as abstrações teóricas) e organizá-los em forma de atividade de estudo ou de ações de aprendizagem. É preciso buscar a essência dessa atividade (desse fenômeno), isto é, ir para além da realidade aparente e encontrar aquilo que verdadeiramente a caracteriza.

Foi com base nessa concepção geral sobre o papel das disciplinas no processo de formação de cada sujeito que iniciamos nossas investigações a respeito da organização do ensino da disciplina de educação física. Buscamos, num primeiro momento, investigar as possíveis relações entre as objetivações genéricas para-si e a educação física, encontrando nessa disciplina aqueles conhecimentos mais diretamente vinculados à categoria de “objetivações genéricas para-si” do materialismo histórico dialético.

Em uma primeira aproximação, as objetivações genéricas vinculadas à arte nos pareceram as que mais se articulavam com o objeto de ensino da educação física, constituindo, na presente pesquisa, o nosso próprio foco de investigação e análise no campo dessa disciplina. Pensávamos que as atividades da cultura corporal estavam mais fortemente vinculadas às atividades humano-genéricas relacionadas à arte, tanto em termos diretos relacionados aos modos de ação e à gênese da atividade (casos mais explícitos da dança e do circo) - quanto em termos mais indiretos, relacionados à apreciação estética (caso dos movimentos esportivos).

Assim, se por um lado essa primeira aproximação que estabelecemos da educação física com as objetivações humano-genéricas relacionadas à arte nos permitem esboçar algumas respostas àquelas questões anteriormente elaboradas por nós sobre o ensino da educação física, para elaborarmos de forma mais consistente o que seja o objeto de ensino dessa disciplina - a partir da teoria histórico-cultural - e como se dá o seu processo de organização do ensino, estamos cientes da necessidade de outras investigações, que abarquem os demais tipos de objetivações genéricas, ou os demais tipos de atividade humana, com suas ações, motivos e formas de conduta. Em outros termos, elaborar uma teoria de ensino para a educação física nos parece ser uma tarefa necessária e que demanda um esforço coletivo de 
sistematização das elaborações já produzidas na área e na criação de novas elaborações, vinculadas à teoria histórico-cultural.

Esta pesquisa, que pode representar um primeiro e parcial esforço na elaboração dessa teoria de ensino para a educação física, teve como objetivo central investigar o processo de organização do ensino para a formação do pensamento estético-artístico nos estudantes.

Como princípios que nortearam a organização desta pesquisa bibliográfico-conceitual e didático-experimental temos:

- é possível organizar o ensino de um modo que seja mais favorável para o desenvolvimento do pensamento teórico, em especial do pensamento estético-artístico;

- podemos definir, como ponto de partida do ensino, os conceitos essenciais da realidade a ser ensinada e aprendida. Neste sentido, é possível identificarmos alguns traços caracterizadores da atividade estético-artística do homem, (particularmente aqueles atrelados às atividades relacionadas à cultura corporal) apontando as funções psíquicas relacionadas a ela.

- é possível, através da organização de um experimento didático, de uma situação de ensino e aprendizagem especialmente organizada, identificar ou revelar os processos de mudanças de qualidade no pensamento estético-artístico dos sujeitos participantes.

A dissertação foi estruturada da seguinte forma:

No primeiro capítulo da dissertação, procuramos apresentar em termos mais amplos algumas possíveis vinculações entre o pensamento estético-artístico e a organização do ensino da educação física, servindo esse capítulo como uma introdução geral ao tema e aos objetivos da pesquisa.

No segundo e no terceiro capítulos fizemos uma análise teórica a respeito da atividade humana relacionada à arte, apontando seus processos de constituição, bem como a relação da atividade artística com a formação do pensamento teórico.

No quarto capítulo, apresentamos discussões teóricas a respeito dos conceitos de atividade de ensino, atividade de estudo e atividade orientadora de ensino, vinculando-os a um modo de organização do ensino para a formação do pensamento estético-artístico.

O quinto capítulo aglutina a parte experimental de nossa pesquisa, tanto no que se refere à organização do experimento didático (realizado com a elaboração de uma unidade didática sobre o circo), quanto à organização dos dados para a análise. No sexto capítulo realizamos a análise propriamente dita dos dados, através dos episódios de ensino e dos episódios de aprendizagem. 
Por fim, no sétimo capítulo, procuramos sintetizar as análises obtidas tanto de nossa pesquisa teórica quanto de nossa pesquisa experimental, de modo a pensarmos o processo de organização do ensino para a formação do pensamento teórico na teoria histórico-cultural. 


\section{INTRODUÇÃO AO PROBLEMA DA FORMAÇÃO DO PENSAMENTO ESTÉTICO-ARTÍSTICO NA EDUCAÇÃO FÍSICA}

Entender o que seja o pensamento estético-artístico e o seu processo de formação em cada sujeito, implica na necessidade de analisarmos tanto a estética e a arte, enquanto atividades humanas, quanto à relação entre educação escolar e o desenvolvimento psíquico. Ambas reflexões partem, neste trabalho, de uma mesma raiz teórica, de uma mesma fundamentação: a teoria histórico-cultural. Como sínteses dessa fundamentação e base para as investigações e análises da formação do pensamento estético-artístico nos homens, citamos:

a) a existência de uma linha histórico-cultural do desenvolvimento (VYGOTSKI, 1995), que se diferencia de sua linha biológica;

b) a necessidade da apropriação dos significados historicamente produzidos nas atividades humanas para que o desenvolvimento cultural de cada sujeito ocorra. (LEONTIEV, 1983).

Ao postular a existência de uma linha biológica e uma linha histórica no processo de desenvolvimento humano, Vygotski ${ }^{2}$ (1995) procura ressaltar os aspectos essenciais que fizeram e fazem o homem se constituir em um ser cultural, o que nos indica a possibilidade de intervenções conscientes no processo de formação de cada sujeito.

A linha biológica do desenvolvimento humano caracteriza-se, sobretudo, por uma relação direta do homem com o mundo, por comportamentos espontâneos ou imediatos, dos quais ele não tem consciência e, assim, não pode controlar plenamente. O segundo tipo de desenvolvimento caracteriza-se pelo surgimento de novas formas de conduta - condutas mediadas -, fruto das conquistas culturais que o homem foi alcançando em suas atividades. Com essas formas culturais de conduta o homem pôde ir criando seus "órgãos artificiais” (instrumentos e signos), formando uma existência consciente ou uma existência para-si.

A cultura origina formas especiais de conduta, modifica a atividade das funções psíquicas, edifica novos níveis nos sistemas de comportamento humano em desenvolvimento [...] No processo de desenvolvimento histórico, o homem social modifica os modos e os procedimentos de sua

\footnotetext{
${ }^{2} \mathrm{O}$ nome deste autor é encontrado com diferentes grafias (i/i; y/y; y/i; i/ii), a depender da tradução realizada de sua obra. Respeitaremos a grafia da obra quando estivermos fazendo referência direta a uma delas e utilizaremos a grafia i/i quando falarmos sobre o autor.
} 
conduta, transforma suas inclinações naturais e funções, elabora e cria novas formas de comportamento, especificamente culturais. (VYGOTSKI, 1995, p.34). ${ }^{3}$

O esforço em se explicitar as especificidades dessas duas linhas de desenvolvimento no homem, a biológica e a cultural, e mais amplamente o esforço em diferenciar os tipos de desenvolvimento do homem comparativamente ao dos animais, inclusive àqueles que nos são mais próximos (como os chipanzés), não se dá com a finalidade de simplesmente estabelecer uma hierarquia de superioridade e, nesse sentido, de desqualificação dos demais animais. Não se trata de um movimento "antropocentrista”. Trata-se, sim, de compreender melhor as ações que permitem a cada homem se formar de acordo com as máximas possibilidades de desenvolvimento produzidas historicamente pela humanidade.

O fato dos macacos poderem aprender uma porção de coisas, inclusive ações tidas como tipicamente humanas (como o uso de instrumentos), não significa que a diferença entre os processos de desenvolvimento de um e de outro inexista. Em primeiro lugar, aquilo que os macacos aprendem, dificilmente, ou nunca, constitui-se numa atividade no sentido próprio dado por Leontiev (1983); trata-se, mais bem, de ações isoladas, com seus significados, mas não de uma atividade estruturada ou de "inteiros modos de ação" (HELLER, 2008). Em segundo lugar, por mais complexo que seja o que o macaco aprende, tal aprendizado e mais do que isso, o não aprendizado desse elemento não implica numa diminuição da sua condição de ser macaco. O que ele aprende não se constitui numa necessidade de vida, ao menos não do ponto de vista da espécie.

Um elefante quebra galhos das árvores e os utiliza para espantar as moscas. Porém, usar galhos para combater as moscas provavelmente não desempenhou nenhum papel considerável na história do desenvolvimento da espécie "o elefante". Os elefantes não se tornaram elefantes pela razão de que seus ancestrais mais ou menos tipo-elefante matavam moscas com galhos. (VYGOTSKY; LURIA, 1996, p.88).

Um cão domesticado (e os animais domésticos em geral) experimenta um certo grau de socialização. Aprende determinados comportamentos que o meio social lhe impõe e cria para si determinadas necessidades também advindas desse meio (como, por exemplo, a necessidade de carinho de seu dono). Entretanto, tanto uma coisa quanto outra, constituem-se em necessidades que não mudam substancialmente o seu comportamento de espécie e, em última análise, não representam necessidades da espécie enquanto tal para que ela mesma se

\footnotetext{
${ }^{3}$ As traduções desta e de outras passagens de obras escritas em espanhol são de responsabilidade da autora.
} 
efetive. Trata-se, no fim, de uma necessidade que lhe é imposta pelo meio, de um comportamento que não se afasta, e na verdade ratifica, o processo geral e universal de desenvolvimento dos animais: o processo de adaptação ao meio.

Para o homem, a coisa se passa de forma diferente. “Toda a existência de um aborígene australiano depende de seu bumerangue, do mesmo modo que toda a existência da moderna Inglaterra depende de suas máquinas” (VYGOTSKY; LURIA, 1996, p.88). Não aprender determinadas coisas, significa concretamente uma impossibilidade real de sua humanização, uma diminuição ou cerceamento de suas possibilidades de se formar enquanto homem. As suas possibilidades de vir a ser homem efetivam-se de acordo com as possibilidades concretas/objetivas para se apropriar daquelas objetivações ${ }^{4}$ humanas historicamente formadas.

Para estabelecer a verdadeira diferença entre os instrumentos humanos e os instrumentos nos animais, devemos analisar, de acordo com Leontiev (1978) a atividade em que eles tomam parte. Para os animais, a sua atividade confunde-se sempre com o seu motivo biológico. Para o animal os instrumentos encerram, em si, uma possibilidade natural de realizar a sua atividade instintiva, ao passo que para o homem, o instrumento possibilita a criação e apropriação de novas formas de atividade do homem no mundo, com os outros e consigo mesmo.

[...] Na vara usada pelo macaco, já podemos ver o protótipo não só de um instrumento em geral, mas de toda uma série de instrumentos diferenciados: pás, lanças, e assim por diante. Porém, mesmo no caso dos macacos que, no mundo animal, encontram-se no ponto mais elevado quanto ao uso de instrumentos, esses instrumentos ainda não desempenham papel decisivo na luta pela sobrevivência. Na história do desenvolvimento do macaco, ainda não houve aquele salto para diante que constituiu o processo de transformação do macaco em homem, e isso, do ponto de vista que nos interessa, termina no fato de que os instrumentos de trabalho tornam-se a base de adaptação à natureza. No processo de desenvolvimento do macaco, esse salto para diante teve início, mas não se completou. A fim de que se complete, é preciso que se desenvolva uma nova forma especial de adaptação à natureza, estranha aos macacos - ou seja o trabalho (VYGOTSKY; LURIA, 1996, p.88).

\footnotetext{
${ }^{4}$ A objetivação refere-se ao processo no qual a atividade humana (física ou mental), adquire uma existência objetiva; isto quer dizer que as características ou aptidões humanas são transferidas ou incorporadas nos produtos da atividade do homem. A objetivação, portanto, refere-se ao processo de produção e reprodução da cultura humana. A objetivação, entretanto, não pode existir sem a presença do processo de apropriação da cultura pelo homem, que é um processo simultaneamente oposto e complementar ao processo de objetivação, em que cada ser singular torna seu aquilo que já foi produzido pela humanidade.
} 
Em outras palavras, a imitação e a utilização de instrumentos nos animais não cria neles um comportamento realmente novo (novos significados), mas tão somente uma forma diferente de realizar o seu comportamento de espécie, tratando-se, assim, de um processo de adaptação. A imitação no ser humano, ou mais amplamente os processos de educação e aprendizagem, são os processos universais de desenvolvimento de cada sujeito enquanto indivíduo pertencente ao gênero humano. São os mecanismos universais para a produção de indivíduos cada vez mais ricos em necessidades humanas.

Diante destas fundamentações expostas, poderíamos pensar em que medida a educação física, uma disciplina que historicamente vem sendo atrelada ao ensino das atividades que envolvem o movimento humano, pode se aproximar dessa concepção cultural de desenvolvimento e, sobretudo, da perspectiva que assinalamos como objetivo dessa pesquisa, de formação de um pensamento estético-artístico.

Ainda que pensássemos que caberia à educação física trabalhar com uma dimensão específica do desenvolvimento humano (o desenvolvimento motor), poderíamos já, apoiados nas discussões de Zaporozhets (1987), apontar que o desenvolvimento da motricidade “[...] está incluso no contexto mais amplo do desenvolvimento da atividade da criança e depende das tarefas que são propostas a ela e dos motivos que a impulsionam a atuar” (idem, p.72). Este posicionamento amplia uma visão estritamente biológica do desenvolvimento motor, que o reduz ao "aprender e aperfeiçoar novos movimentos” e nos indica que ao falar em desenvolvimento motor estamos falando, antes, em desenvolvimento humano em geral e que, portanto, há, também, nele duas linhas: uma biológica e natural e uma histórica e cultural. Contudo, isto ainda não nos diz, explicitamente, o que de verdadeiramente cultural pode e deve se desenvolver nos sujeitos mediados pelos conhecimentos da educação física.

Poderíamos desdobrar essa questão em outras: em que sentido ou em que direção a experiência cultural relacionada ao movimento humano, relacionada às atividades da cultura corporal contribui para a formação do desenvolvimento dos indivíduos? Quais os processos que a cultura, organizada pelo ensino da educação física, direciona ou desencadeia no processo de desenvolvimento do homem? E, especificamente, como o ensino da educação física pode contribuir no processo de formação do pensamento estético-artístico?

Essas perguntas servirão de referência para as reflexões subseqüentes a serem feitas neste trabalho, que buscarão apontar alguns encaminhamentos teórico-metodológicos para a organização do ensino e do ensino da educação física. 


\subsection{Sobre o objeto a ser apropriado no ensino da educação física.}

Ao tratar dos movimentos que são especificamente humanos Zaporózhets (1987) fala em “forma superior de movimento”, ressaltando aí o seu caráter voluntário e consciente. A possibilidade de se relacionar de maneira inteiramente consciente e deliberada com o movimento, de fazer o movimento de acordo com um planejamento prévio e ter consciência disso, reflete a aquisição de um tipo essencialmente cultural da conduta. Assim, poderíamos supor que o objeto a ser apropriado pelos educandos nas aulas de educação física seria, justamente, essa dimensão do “para-si” de seus próprios movimentos. À educação física caberia a formação, nos educandos, desta consciência da execução de suas ações motoras.

Entretanto, pensamos que, juntamente com este controle voluntário das ações motoras, uma outra forma do desenvolvimento motor, em sua linha cultural, se manifestar seja a partir dos tipos de significados possíveis de serem apropriados nas atividades relacionadas à cultura corporal. Conforme nossa perspectiva teórica na área da Educação Física ${ }^{5}$, o homem pode relacionar-se, nas atividades envolvendo o movimento humano, com os significados: estético, agonístico, artístico, lúdico e competitivo.

Estes significados não se encontram diretamente no corpo de quem realiza os movimentos, não estão na ação motora em si mesma, mas sim na atividade da qual o sujeito toma parte. É a atividade a portadora do significado, sendo ela apropriada e objetivada através do indivíduo, via suas ações motoras ${ }^{6}$.

As atividades relacionadas à cultura corporal fazem parte, para nós, das chamadas objetivações genéricas. Trata-se de elaborações que permitem um relacionamento homem/ mundo de uma maneira não cotidiana ou utilitária, que lhes permita sair da vida cotidiana. Embora a vida cotidiana seja a "vida de todo homem” (HELLER, 2008) e que o sujeito ao assimilar a cotidianidade de sua época assimila todo o passado da humanidade, é preciso considerar que "tal assimilação possa não ser consciente, mas apenas em si”. (Idem, p.20). Em outras palavras, o homem relaciona-se com o humano genérico sem ter consciência dessa relação.

\footnotetext{
${ }^{5}$ Coletivo de Autores (1992), Nascimento (2004; 2009).

${ }^{6}$ Os termos ação motora, habilidade, destreza e movimento, que de certa forma representam um mesmo fenômeno precisarão ser investigados e melhor conceituados. Daremos preferência aqui pelo termo ação motora ao nos referirmos ao movimento humano por considerar que nele já esteja representada a idéia do movimento mais o contexto/ objetivo.
} 
Deste modo e como qualquer objetivação genérica, as atividades da cultura corporal apresentam uma dimensão em-si (simplesmente “jogar”, sem se apropriar dos significados estratégicos do jogo, por exemplo) e uma dimensão para-si ${ }^{7}$ (onde o sujeito domina inteiramente a atividade e os elementos que compõem a atividade: em nosso exemplo, as regras, os objetivos e as estratégias do jogo).

Deste modo, o objeto a ser apropriado a partir do ensino da educação física, de modo a contribuir para o desenvolvimento cultural dos sujeitos, seria, num aspecto mais amplo, os significados atrelados às atividades da cultura corporal e, num aspecto mais específico, os conceitos nucleares ou essenciais presentes em cada atividade ou manifestação corporal. Tais significados e conceitos carregam em si determinadas capacidades e condutas, determinadas formas culturais do homem estar e se relacionar com o mundo e consigo mesmo.

As atividades da cultura corporal podem ser agrupadas em 5 eixos gerais: o Esporte, o Jogo, a Dança, a Ginástica e as Lutas (COLETIVO, 1992). Numa análise inicial, pensamos que esses eixos (e que as manifestações contidas neles) estão relacionados, em sua origem, com o trabalho, com as atividades produtivas do homem; isto é, derivam delas.

Algumas premissas das pesquisas do Jogo desenvolvidas notadamente por Elkonin (1998) nos apontam para essa aproximação. Elkonin (1998) e Plekhanov (1965) afirmam que a arte e o jogo apresentam uma mesma raiz genética, uma mesma gênese: a arte e o jogo têm como origem o trabalho humano produtivo. Em uma concepção materialista da história, a arte e o jogo não são atividades primárias do homem; elas surgem em um momento posterior no curso de desenvolvimento das atividades humanas, fruto dos processos de desenvolvimento da própria sociedade.

A concepção geral de que a atividade primária dos homens (de um ponto de vista filogenético) é o trabalho, aplica-se com toda a propriedade para a análise das atividades da cultura corporal e para a análise do próprio processo de desenvolvimento motor do homem. A partir do trabalho e ao longo de seu desenvolvimento, vão sendo criadas outras ou novas necessidades (estéticas e artísticas, por exemplo), necessidades essas que em seus processos de objetivação foram criando, também, a possibilidade de novas formas de atividades (como as artísticas, esportivas, científicas...) e novas formas de conduta e de pensamento.

Num primeiro momento do processo de desenvolvimento da humanidade (filogênese), podemos supor que os homens se movimentavam de acordo com finalidades estritamente utilitárias. No período da idade da pedra - período paleolítico - os homens viviam da caça, da

\footnotetext{
${ }^{7}$ Sobre esses conceitos de objetivações genéricas em-si e para-si, ver o trabalho de Newton Duarte, $A$ individualidade para-si (1993).
} 
pesca e da coleta de grãos, raízes, animais lentos e mariscos (GORDON CHILD, 1965). Os seus movimentos deveriam estar, então, vinculado às atividades produtivas e à utilização dos instrumentos correspondentes a esta atividade de trabalho. A possibilidade de "se movimentar” a partir de outros significados (estético, lúdico, artístico), buscando outros fins, aparece em um momento posterior no processo de desenvolvimento humano, quando a humanidade passa a ter uma relativa autonomia do trabalho, ao obter excedentes na produção, o que "liberava” certos indivíduos da aldeia ou comunidade para se dedicarem a outras atividades, como a pintura, os rituais de magia e a confecção de instrumentos de metais. (GORDON CHILD, 1965). Esse momento deu-se durante e após o período neolítico (aproximadamente 3.000 a.c).

Ainda em uma análise inicial, pensamos que o percurso do desenvolvimento motor na filogênese seguiu as seguintes etapas: em um primeiro momento as ações motoras se manifestaram como ações não conscientes, portanto, ainda não de pleno domínio do homem. Neste momento, no início do desenvolvimento cultural do ser humano, no processo mesmo de consolidação da espécie Homo Sapiens, o homem vivia, ainda, em relações quase que inteiramente espontâneas com a natureza, sendo seus movimentos respostas mais ou menos diretas aos estímulos apresentados pelo meio (trepar na árvore, saltar um obstáculo, arremessar pedras para afugentar animais etc.).

Num momento posterior, em que o trabalho já se configurava como uma atividade organizada da tribo ou aldeia (período paleolítico da história), as ações motoras tornam-se conscientes, porque vinculadas organicamente à atividade de trabalho produtivo. Nesse momento, a elaboração de novos instrumentos foi uma das bases que permitiu o concomitante aperfeiçoamento e/ou criação de novos movimentos ou ações motoras. Podemos supor com bastante justeza, que foi a necessidade de aprimorar o trabalho e a consciência do produto deste trabalho (objetivação) que fizeram com que esses movimentos tendessem a se aprimorar cada vez mais e a se tornarem cada vez mais conscientes para o homem; cada vez mais “movimentos para-si”. Podemos dizer, então, que foi a atividade de trabalho, portadora de determinadas capacidades e necessidades humanas (como a relação consciente homem/produto e a concomitante elaboração de uma finalidade consciente) a que permitiu a criação de uma relação consciente homem/movimento.

Num terceiro momento (correspondente ao período neolítico e pós-neolítico da história, depois de 3.000 a.c), e porque a atividade de trabalho dos homens foi se diversificando, alcançando níveis produtivos relativamente elevados e, assim, liberando membros da comunidade para se dedicarem a outras atividades vinculadas à tribo - que não as 
diretamente produtivas - as ações motoras conscientes passaram a se vincular a outras esferas da vida que foram surgindo para além do trabalho produtivo (atividades ritualísticas, lúdicas, artísticas etc.). Essa ampliação das esferas da vida permitiu a criação de novos significados para as ações motoras e novas necessidades para o homem, posto que se inseriam, concreta e objetivamente, em novas atividades: atividades de apresentação artística e exibição (significado artístico e estético); atividades de treino das habilidades corporais (significado agonístico); atividades de brincadeiras sem relação direta com as atividades produtivas (significado lúdico). Este terceiro momento caracteriza-se pela criação de novos motivos (pela transformação de ações em motivos) a partir da atividade humana de trabalho, o que levou à criação de novas atividades.

Na ontogênese o desenvolvimento não repete o processo da filogênese, seguindo um percurso próprio. Em um primeiro momento (período neonatal), as ações motoras se relacionariam com as atividades vinculadas à satisfação das necessidades de sobrevivência (manutenção da postura, sucção, deslocamento etc). Num momento posterior e/ou concomitante a esse, as ações motoras relacionar-se-iam, fortemente, com as atividades de testagem das possibilidades corporais em si mesmas, isto é, testagem das formas de se mover num mundo de objetos e relações culturais ${ }^{8}$. Neste momento, o movimento não seria, ainda, objeto da "consciência” do sujeito, estando, apenas, em uma esfera do em-si. A relação com os outros sujeitos, em especial com os adultos, é que vai propiciando a passagem desse movimento em si para um movimento para-si. Tratando da relação da formação ou da constituição do gesto na criança, Vygotski faz considerações que julgamos serem pertinentes para pensarmos o próprio processo de desenvolvimento do movimento consciente:

A criança, portanto, é a última a tomar consciência de seu gesto. Seu significado e funções se determinam a princípio pela situação objetiva e depois pela gente que rodeia a criança. [...] Cabe dizer, portanto, que passamos a ser nós mesmos através de outros.[...] A personalidade vem a ser para si o que é em si, através do que significa para os demais (VIGOTSKY, 1995, p.149).

Somente num terceiro momento, as ações motoras poderiam se relacionar às atividades das esferas não cotidianas da vida: arte, trabalho, jogo etc. Nesse processo, mediado pelas atividades em questão, a relação do indivíduo com o seu movimento vai se

\footnotetext{
${ }^{8}$ É bem conhecido o fato de que a nossa forma de andar, de segurar objetos, de portar o corpo quando falamos com alguém etc, são formas estritamente culturais e que, portanto, cada indivíduo deve se apropriar ao longo de sua vida. Estas apropriações dão-se de forma espontânea, na vida cotidiana de cada sujeito. Ver, por exemplo, os trabalhos de Marcel Mauss (1974) a respeito.
} 
dando de maneira cada vez mais consciente (cada vez mais para-si) posto que vai se apropriando de novos significados e de novas possibilidades de estar e agir no mundo.

Esse processo de desenvolvimento e de humanização dos indivíduos que ocorre na ontogênese e esboçado por nós nos parágrafos anteriores, por meio das atividades relacionadas ao movimento humano, deve se dar de maneira sistemática na escola, isto é, deve se dar de modo que a relação dos sujeitos com as atividades da cultura corporal se dêem numa dimensão mais do "para-si” do que numa dimensão do “em-si”. E historicamente, a disciplina encarregada desse processo ou que tem as possibilidades de refletir e elaborar sobre ele, é a educação física.

Assim, compreender o processo de formação cultural a partir das atividades da cultura corporal, revelando as formas de conduta que elas de fato podem fazer emergir em cada sujeito, contribui para revelar as condições e circunstâncias do trabalho pedagógico da educação física que possam direcionar a formação do pensamento teórico nos educandos, dentre eles, o pensamento estético-artístico.

\subsection{Sobre o estudo do pensamento estético-artístico.}

Ao se apropriar de um dos mencionados significados relacionados às atividades da cultura corporal e, portanto, ao se apropriar dessas próprias atividades, cada sujeito se apropria, também, de novas formas de conduta, de funções psicológicas superiores (VYGOTSKI, 1995), como a atenção voluntária, a memória lógica, a imaginação criadora e o pensamento teórico. Essas formas de conduta são parte daquilo que, na teoria históricocultural, considera-se ser um modo específico do homem estar e se relacionar com o mundo: um modo especificamente cultural.

O pensamento teórico, como uma dessas formas culturais de conduta, que permite ao homem compreender os fenômenos da realidade em sua essência, é uma das apropriações fundamentais que devem ser garantidas na escola, para cada educando.

A partir dessa perspectiva, uma primeira questão pode ser colocada: como se caracteriza o pensamento teórico na educação física? É possível falarmos em pensamento teórico em uma disciplina que, em sua aparência, seja eminentemente prática ${ }^{9}$ ? Em primeiro

\footnotetext{
${ }^{9}$ Nos textos da LDB (1961 e 1971) a educação física ainda é considerada como uma atividade prática (em detrimento de uma disciplina como as demais áreas). Essa compreensão, ainda que tenha sido superada legislativamente (LDB 1996) e em algumas perspectivas teóricas (vinculadas a uma perspectiva cultural) e
} 
lugar, compreendemos que não se trata, aqui, de forçar uma teorização em torno do ensino da Educação Física, de opor a teoria e a prática, mas, justamente, de compreender quais as relações internas, essenciais, presentes em uma dada atividade da cultura corporal, que precisam ser ensinadas e aprendidas para que o sujeito possa delas se apropriar (fazer delas uma atividade para-si). Em outras palavras: é preciso definir quais os conhecimentos conceituais e quais as formas de conduta (pensamento teórico, imaginação, memória lógica etc.) presentes nessas atividades que precisam ser explicitadas e organizadas para a sua apropriação pelos educandos.

Já mencionamos que essas relações internas ou essas formas de conduta estariam presentes nos significados das atividades (significados lúdico, estético, artístico, agonístico e competitivo). Entretanto, realizar apenas essa afirmação não nos ajuda a avançar com relação à organização da atividade de ensino da educação física. É preciso elaborar, a partir desses significados e para cada um deles, qual a especificidade do pensamento possível de ser formado. Assim, para cada atividade, haveria uma forma de pensamento (e conduta) que materializasse ou reproduzisse uma relação específica do homem com o mundo.

Em termos gerais, e como esboço, poderíamos apontar os tipos de pensamento relacionados à educação física ${ }^{10}$ e alguns exemplos de manifestações da cultura corporal correspondentes a eles, bem como uma caracterização prévia dos mesmos, com base nas formas especificas de condutas que julgamos ser centrais nas atividades relacionadas a esses pensamentos:

\begin{tabular}{|l|l|l|}
\hline $\begin{array}{l}\text { TIPOS DE } \\
\text { PENSAMENTO }\end{array}$ & $\begin{array}{l}\text { EXEMPLOS DE } \\
\text { MANIFESTAÇÕES }\end{array}$ & CARACTERÍSTICAS \\
\hline Estético & $\begin{array}{l}\text { N }^{*} \text { manifestações } \\
\text { manifestações da cultura corporal }\end{array}$ & $\begin{array}{l}\text { Entendimento e vivência de que o } \\
\text { movimento seja fonte de apreciação e } \\
\text { de beleza }\end{array}$ \\
\hline Estratégico & $\begin{array}{l}\text { * potencialmente, quaisquer } \\
\text { manifestações da cultura corporal }\end{array}$ & $\begin{array}{l}\text { Capacidade para analisar as situações e } \\
\text { tomar as decisões mais adequadas de } \\
\text { acordo com o objetivo ou finalidade } \\
\text { proposto; }\end{array}$ \\
\hline Lúdico & $\begin{array}{l}\text { Brincadeiras e Jogos Populares, } \\
\text { Materiais. }\end{array}$ & $\begin{array}{l}\text { Entendimento e vivência das ações } \\
\text { motoras como possibilidade de } \\
\text { divertimentos e aprendizagens }\end{array}$ \\
\hline
\end{tabular}

proposições curriculares (como os PCNs), ainda não se encontra plenamente superada nem na prática pedagógica dessa disciplina, nem nas perspectivas teóricas atreladas a ela, posto que há divergências quanto a concepção e papel da "teoria" na formação dos sujeitos.

${ }^{10}$ Não se trata de tipos de pensamento específicos da educação física. Estes pensamentos estão presentes, ou são formados, em outras atividades humanas, o que significa que possuem uma dimensão genérica. Entretanto, uma vez que não podem ser formados fora de relações concretas, de um objeto de estudo concreto, eles se formam tendo por base algumas características específicas referentes ao objeto que lhe serviu de base. 


\begin{tabular}{|l|l|l|}
\hline & & $\begin{array}{l}\text { (consciência do movimento) e como } \\
\text { um fim em si mesmo (no ato de jogar/ } \\
\text { brincar: "brincar da melhor forma } \\
\text { possível”). }\end{array}$ \\
\hline Lúdico-Estratégico & Jogos Coletivos, Capoeira & $\begin{array}{l}\text { compreensão e sensibilidade aos } \\
\text { objetivos e circunstâncias do jogo e } \\
\text { capacidade de analisar as } \\
\text { possibilidades de ações existentes } \\
\text { (individuais e coletivas), tomando as } \\
\text { decisões adequadas para o momento } \\
\text { em questão. }\end{array}$ \\
\hline Estético-Artístico & Circo, Dança; Ginástica Rítmica. & $\begin{array}{l}\text { a) entendimento e vivência de que o } \\
\text { movimento seja fonte de apreciação e } \\
\text { de beleza } \\
\text { b) compreensão e sensibilidade às } \\
\text { intencionalidades artísticas das ações } \\
\text { motoras e capacidade para organizar e } \\
\text { apreciar as diferentes possibilidades de } \\
\text { organização de seus elementos (forma, } \\
\text { espaço, tempo e significado). }\end{array}$ \\
\hline
\end{tabular}

Quadro 1: Tipos de pensamentos e suas características na educação física.

Dentre os pensamentos acima mencionados, interessa-nos desenvolver, particularmente, um deles: o pensamento estético-artístico. Os referidos tipos de pensamento, não são, como já mencionamos, especificidades da educação física. O pensamento que estamos chamando de estético-artístico, por exemplo, pode ser formado na literatura, na pintura ou no circo. Embora haja características comuns na formação do pensamento estético em todas essas atividades, a começar pelo objetivo (o artista visa, em todas elas, criar um objeto artístico com o qual o público possa se relacionar), as especificidades dos objetos e ações que mediam a formação do pensamento estético-artístico (as palavras em um, as cores e traços em outro e os movimentos no terceiro) resultam em sensibilidades estéticas também específicas. A forma, isto é, o modo específico como se manifesta um objeto artístico, resulta em formas específicas de sensibilidade do mesmo. Não há, portanto, um pensamento estéticoartístico em si mesmo, fora de relações (objetivações) concretas, o que não nega a existência de uma dimensão genérica desse tipo de pensamento.

Uma criança que esteja iniciando, sistematicamente ${ }^{11}$, a formação de seu pensamento estético-artístico em uma dessas áreas, dificilmente conseguirá relacionar-se de maneira estética (apreciar ou realizar ações) em outra área na qual não esteja familiarizada; ao menos não espontaneamente.

\footnotetext{
${ }^{11}$ Ao utilizarmos, nesse trabalho, a palavra sistematicamente ou ensino sistematizado, estamos nos referindo a um ensino ou a uma atividade intencionalmente organizada por um educador e que vise criar as condições para que os estudantes estejam em atividade de estudo.
} 
Assim, embora o pensamento estético-artístico (e qualquer outra forma de pensamento) apresente uma dimensão geral, ele não se forma como um pensamento em si mesmo, mas como um pensamento a partir de e vinculado a um objeto concreto, com relações e atividades humanas concretas. Entretanto, podemos supor que um sujeito que tenha já desenvolvido muito bem o seu pensamento estético-artístico em uma das áreas mencionadas, e porque as generalizações que obteve estão em um grau bastante elevado, terá uma sensibilidade estética muito maior para as demais manifestações/atividades em que ela esteja presente. Certamente, algum grau de familiaridade ele terá que ter com essas outras atividades (se sua formação se deu na dança, algum conhecimento terá de ter do circo para poder se relacionar com ele de forma estético-artística). Esta relação estético-artística com o Circo, desse sujeito que teve seu pensamento plenamente desenvolvido na Dança, deverá se dar de forma muito mais rápida e aprofundada que a de um "leigo" nas questões do pensamento estético-artístico ou a de um iniciante no estudo do circo.

Assim, supomos que a formação de uma das modalidades específicas de pensamento a que nos referimos não garante, em princípio, a formação deste mesmo pensamento em geral, para toda e quaisquer atividades humanas em que ele possa aparecer. Entretanto, a sua formação cria as bases para a ocorrência de uma posterior generalização desse tipo de pensamento. Isto é, a amplitude da transferência de um determinado pensamento para uma outra área (distante da onde se deu a sua formação) não ocorrerá espontaneamente, sobretudo se este pensamento ainda estiver no início de sua formação, mas poderá ocorrer em um momento posterior de seu desenvolvimento (quando tiver alcançado as suas máximas possibilidades) e/ou se for devidamente orientado por atividades específicas que busquem realizar essa transferência.

O que queremos ressaltar, aqui, é a importância de formar o pensamento estéticoartístico de modo a ressaltar as suas dimensões genéricas, ainda que as mesmas se dêem, necessariamente, a partir de um objeto específico. Ao pensarmos na formação do pensamento estético-artístico a partir da educação física (e a partir de uma manifestação específica: o circo), procuraremos ressaltar não apenas a especificidade dessa formação (especificidade vinculada a seu objeto), mas também os aspectos gerais da mesma: as dimensões genéricas do pensamento estético-artístico. 


\title{
2. A ARTE E A ESTÉTICA
}

\begin{abstract}
Vai-se tomando consciência cada vez mais clara da idéia segundo a qual a arte só poderá ser objeto de estudo científico quando for considerada uma das funções vitais da sociedade em relação permanente com todos os outros campos da vida social e no seu condicionamento histórico concreto. Dentre as tendências sociológicas da teoria da arte, a que mais avança e apresenta maior coerência é a teoria do materialismo histórico, que procura construir uma análise científica da arte à base dos mesmos princípios aplicados ao estudo de todas as formas e fenômenos da vida social (VIGOTKSI, 2001, pp.8-9).
\end{abstract}

Entender o que é a Arte ou mais precisamente, o que é uma atividade artística, nos remete a necessidade de definirmos a atividade humana em geral. Analisaremos nos próximos tópicos a arte e a estética, procurando revelar tanto as suas gêneses, quanto o papel que desempenharam e ainda desempenham para a formação de cada sujeito. Tais análises irão contribuir para a elaboração conceitual do que seja o pensamento estético-artístico e para o entendimento das condições e circunstâncias do ensino para o processo de formação deste pensamento em cada um de nós.

\subsection{O papel do trabalho e da atividade no processo de ontogênese humana e sua relação com a arte.}

Em uma perspectiva materialista histórico-dialética a atividade humana genérica é o trabalho. É o tipo de atividade que, fundamentalmente, humaniza e possibilita o desenvolvimento da cultura em geral e do homem cultural em particular. Ao trabalhar, o homem produz não apenas a sua vida biológica e, amplamente, a sua vida social, mas também, a sua vida psíquica.

O trabalho é, assim, uma atividade própria do homem, a forma específica dele se relacionar com o mundo. Entendido como a relação dialética entre objetivação e apropriação $^{12}$, o trabalho expressa a dinâmica essencial de autoprodução do homem pela sua atividade social.

\footnotetext{
${ }^{12}$ Sobre esses conceitos, ver a $4^{\text {a }}$ nota de rodapé.
} 
O homem só é homem objetivando-se, criando objetos nos quais se exterioriza. Pode se dizer, por isso, que é ao mesmo tempo sujeito e objeto, e que só é propriamente sujeito humano, na medida em que se objetiva, em que se faz objeto (VAZQUEZ, 1968, p.59).

Como resultado desse processo, temos que o homem ou o sujeito (singularidade) por meio do trabalho e sob determinadas condições sociais (particularidade) humaniza-se, produzse a si mesmo e torna-se parte do gênero humano (universalidade). Em outros termos, o singular só se forma mediante a apropriação do universal, que é, por sua vez, sempre mediado pelo particular (OLIVEIRA, 2005). O trabalho permitiu ao homem apropriar-se da natureza e transformá-la; permitiu que ele se tornasse produtor de sua própria vida.

A apropriação do processo de trabalho pelo homem permitiu que ele assumisse uma postura de criador perante a natureza; ele passou a exigir ou a forçar, cada vez mais, que a natureza lhe desse o que ele queria. Desta forma, por realizar na natureza seus desejos, ou mais precisamente seus fins, o homem objetivou-se no mundo, humanizou os objetos e o mundo e, nesse processo, pode humanizar-se a si próprio. Portanto, o trabalho permitiu ao homem transformar a natureza e criar um mundo humano. O trabalho permitiu que ele se transformasse a si mesmo, criando novas formas de conduta: condutas especificamente culturais (VYGOTSKI, 1995).

No trabalho, então, o sujeito e o objeto encontram-se numa relação mediada. Entre o sujeito que produz o objeto e o objeto produzido está a finalidade, a idéia ou imagem ideal. Fischer (1976) afirma que o uso de ferramentas no processo de trabalho possibilitou a realização da inversão da relação natural de causa e efeito. Por conta do uso de ferramentas (mais precisamente por conta da atividade mediadora ou instrumental do homem de maneira geral), o “efeito" passou a ser previsto, antecipado e, assim, transformado em propósito. O propósito ou finalidade passou a estar presente durante todo o processo de trabalho, governando e condicionando o trabalhador e suas formas de conduta (as quais deveriam estar subordinadas aos propósitos estabelecidos). A ação do homem e sua forma de conduta passam a ser conscientes: o homem sabe o que quer antes de começar a agir, e age do princípio ao fim, de acordo com o propósito que colocou para si próprio (FISCHER, 1976).

O fato de o homem prever, antecipadamente, o resultado de seu trabalho, de ter o produto de seu trabalho pronto na sua mente antes de iniciar a sua atividade propriamente dita, significou uma mudança sumamente importante no seu comportamento. Possibilitou, em última análise, que ele controlasse conscientemente seus atos, que direcionasse sua conduta para a objetivação daquele seu propósito, que, antes, só existia em sua mente. O homem, por 
ter suas ações, condutas, direcionadas e organizadas por si próprio, ou seja, por ter uma “ação consciente”, passou a ser também um “ser consciente” (FISCHER, 1976).

É a partir dessa concepção de trabalho humano que podemos entender a relação trabalho/atividade humana/arte sintetizada por Fischer (1976, p.21): “A Arte é quase tão antiga quanto o homem. É uma forma de trabalho, e o trabalho é uma atividade característica do homem.”

Aproximar a arte do trabalho significa, em primeiro lugar, afirmar que ela é um tipo específico de atividade humana, que depende da mesma estrutura de todas as atividades humanas em geral. O determinante para a arte, para a produção artística, não é a "inspiração" ou o “dom” com o qual supostamente algumas pessoas teriam nascido, mas sim a relação entre a apropriação dos instrumentos, técnicas e formas de conduta historicamente produzidas pela humanidade e encarnadas na cultura humana universal (material e simbólica) e sua objetivação em forma de objeto artístico.

[...] o trabalho para um artista é um processo altamente consciente e racional, um processo ao fim do qual resulta a obra de arte como realidade dominada, e não - de modo algum - um estado de inspiração embriagante. Para conseguir ser um artista, é necessário dominar, controlar e transformar a experiência em memória, a memória em expressão, a matéria em forma. A emoção para um artista não é tudo; ele precisa também saber tratá-la, transmiti-la, precisa conhecer todas as regras, técnicas, recursos, formas e convenções com que a natureza - esta provocadora - pode ser dominada e sujeitada à concentração da arte (FISCHER, 1976, p.14).

Em segundo lugar, a aproximação da arte ao trabalho, implica em entendermos essa relação de um ponto de vista filogenético. A arte, assim como o jogo, tem como origem o trabalho humano produtivo (ELKONIN, 1998; PLEKHANOV, 1965; VAZQUEZ, 1968). Nos períodos iniciais da formação do gênero humano não haviam tipos diferenciados de atividades. Havia o trabalho, com suas diversas facetas e ações, mas não havia ainda um outro tipo de atividade ${ }^{13}$, posto que o motivo de todas as ações humanas era governado por uma mesma necessidade: a sobrevivência.

A atividade fundamental do homem cumpria uma função estritamente práticoutilitária, posto que visava satisfazer uma necessidade utilitária vinculada à sobrevivência

\footnotetext{
${ }^{13}$ Analisaremos mais detidamente, em outro momento deste trabalho, a categoria de atividade e os elementos que a constituem (necessidades, motivos, ações, operações) a partir das elaborações teóricas de Leontiev (1978, 1983, 1991).
} 
(alimentação, proteção...), via criação de novos objetos. Essa atividade fundamental era o trabalho.

Para produzir objetos essencialmente artísticos, para que o homem pudesse criar para si novas necessidades (que não fundamentalmente utilitárias) e, nesse processo, criar novas atividades, foi preciso, antes, que a produtividade do trabalho humano fosse elevada a um grau considerável. A criação artística expressa em toda a sua plenitude e liberdade, o conteúdo psíquico que nos produtos do trabalho expressam-se, na maioria das vezes, de forma limitada. Como afirma Vazquez (1968, p.73): “O trabalho é assim, histórica e socialmente, a condição necessária do aparecimento da arte, bem como da relação estética do homem com seus produtos”.

As ações existentes de reprodução gráfica das caçadas, pintando-as, por exemplo, são o resultado de muitos anos de trabalho humano produtivo, de desenvolvimento da atividade de caça (de modo que a mesma pudesse ser representada na mente dos homens), bem como do desenvolvimento de instrumentos gráficos e das capacidades de operar com eles.

O aperfeiçoamento dos diversos objetos produzidos pelo homem em sua atividade de trabalho resultou na possibilidade do homem se relacionar de dois modos distintos com o produto de seu trabalho: a) como um objeto de interesse pela sua utilidade material e prática (direcionada à satisfação das necessidades humanas de sobrevivência); b) como um objeto cujo interesse estava em sua utilidade "psíquica” (como uma forma de testemunhar a capacidade criadora do homem) (VAZQUEZ, 1968). Foi neste processo, de acordo com este mesmo autor, que uma nova necessidade pôde ir se constituindo na humanidade, necessidade esta que hoje chamamos de estética.

Em um determinado momento da história da humanidade, a produção de um instrumento de trabalho (um machado, por exemplo), pôde ser não só um objeto que correspondesse a necessidades utilitárias de caça ou preparo de alimentos, mas também um objeto a ser "contemplado”. A contemplação tem aqui um significado bastante peculiar: tratase do fato do homem ter podido olhar o objeto e se relacionar com ele consciente de que se tratava de um produto de seu trabalho; consciente de que ele possuía uma determinada forma, um determinado aspecto e de que tais formas e aspectos poderiam ser modificados por ele. E o importante, neste momento, é que a modificação realizada no objeto, o trabalho humano realizado no objeto, pôde adquirir certa autonomia com relação a sua função utilitária. O trabalho humano encarnado no machado não conduzia o objeto para uma melhor função na caça, mas sim, para que se transformasse em um objeto decorado. 
Ultrapassando as exigências práticas, no próprio seio do objeto útil, o artista dos tempos pré-históricos adorna os ossos de rena ou de mamute, fazendo estrias que se alternam simetricamente, isto é, introduzindo temas decorativos. A transformação das qualidades naturais do objeto se opera nestes casos mediante considerações que ultrapassam o ponto de vista meramente utilitário (VAZQUEZ, 1968, p.77).

A relação entre trabalho e arte pode ser posta, então, da seguinte forma: a arte prolonga o trabalho na medida em que o trabalho vincula-se com a essência humana (criadora); e a arte é uma forma específica de criação humana. Por outro lado, a arte é irredutível ao trabalho, posto que supera aquilo que há de fundamental nele: a sua significação prático-utilitária (VAZQUEZ, 1968).

Ao decorar um instrumento de trabalho o homem deu um passo decisivo para a elaboração de uma nova atividade humana (a atividade artística), muito embora nesses primórdios da humanidade, a decoração do instrumento (ainda que mantivesse certa autonomia da atividade utilitária de trabalho) estava, ainda, organicamente vinculada a ela. Em outros termos, podemos dizer que neste momento da história da humanidade, o homem ainda não havia criado uma atividade artística, mas sim ações relacionadas à arte. Ao dizermos isso, estamos pontuando que a decoração dos instrumentos, embora tivesse o objetivo de decorar, de torná-lo mais "bonito”, ainda estava inserido no motivo da atividade de trabalho em geral: caçar, coletar alimentos e proteger-se. Como o motivo seguia sendo o mesmo, a decoração de um instrumento era uma ação e não uma atividade propriamente dita. Apenas em um momento posterior e como resultado do desenvolvimento tanto da atividade de trabalho em geral (desenvolvimento das forças produtivas), quanto da ação específica de decoração, esta ação pôde transformar-se em uma nova atividade, no caso, a atividade artística. Em outras palavras, o objetivo de decorar, passou a desempenhar a função de motivo para o sujeito e assim, de ação, passou a se constituir em uma nova atividade. Neste momento, a atividade artística passa a se relacionar com a atividade de trabalho apenas de um ponto de vista ontológico: a arte é trabalho humano porque expressa, por meios singulares, a capacidade criadora do homem.

Esse mecanismo exposto acima pode ser pensado para quaisquer outras atividades humanas que, estando inicialmente presentes na própria atividade de trabalho, enquanto ações diferenciadas, puderam se desenvolver e formar novas atividades humanas. 


\subsection{O objeto, a conduta, a Atividade e a formação dos sentidos humanos.}

A concepção geral de que a atividade primária dos homens (de um ponto de vista filogenético) é o trabalho, constitui-se em uma referência para a análise das atividades artísticas. A partir do trabalho, com a ampliação e diversificação dos objetos e das ações que o realizam - com a ampliação e diversificação das formas do homem se relacionar com o mundo - vão sendo criadas outras ou novas necessidades (estéticas e artísticas, por exemplo). Essas necessidades, em seus processos de satisfação, foram criando, também, a possibilidade de novas formas de atividades (a religião, a arte, a brincadeira etc.) e novas formas de conduta e de pensamento.

A criação dessas novas atividades esteve e ainda está atrelada à necessidade humana em geral de se objetivar no mundo, isto é, de fazer com que as suas capacidades, intenções e sentimentos possam ser materializados fora de si e, nesse processo (objetivação) o homem possa, ele mesmo, se humanizar. A realização do homem como ser cultural, como ser pertencente ao gênero humano, só pode ocorrer mediante a objetivação do homem no mundo, ou seja, na medida em que se faz a si mesmo em objeto; na medida em que cria objetos que o exteriorizem. É neste sentido que a atividade humana tem um caráter objetal. E é neste sentido, também, que a arte cumpre uma importante função no processo de humanização dos homens: a atividade artística também deve criar objetos que guardam em si determinadas capacidades, condutas e significações humanas.

As atividades artísticas, ou talvez devêssemos dizer as ações artísticas inicialmente desenvolvidas pelos homens, cumpriam uma função de humanização tal qual a atividade de trabalho em geral. "Um meio de expressão - um gesto, uma imagem, um sim, uma palavra era tão instrumento como um machado ou uma faca. Era apenas outro modo de estabelecer o poder do homem sobre a natureza”. (FISCHER, 1976, p. 40).

O fato de as atividades artísticas (no caso, os gestos, as imagens, as palavras) desempenharem um papel de instrumento, nos parece sumamente importante. Vygotski (1995) explicita a diferenciação entre os instrumentos-ferramentas (que tem como função dominar a natureza externa, criar o mundo humano, cultural, na natureza) e os instrumentossignos (que tem como função dominar a natureza do próprio homem, suas formas de conduta, seus modos de estar e agir no mundo, criando uma conduta propriamente humana ou cultural). Se por um lado esses signos e as ações a eles vinculadas (a fala, o canto, o gesto e a pintura, por exemplo) estavam, em seu início, intimamente ligados à atividade de trabalho produtivo, vinculados às necessidades eminentemente prático-utilitárias do homem, com o tempo eles 
foram se vinculando a outras necessidades (ou criando-as) e podendo, assim, constituir atividades humanas específicas.

Uma vez surgidas outras atividades humanas e produzidos outros instrumentos, podemos supor que o homem não só passou a dominar mais a natureza externa, como passou a dominar mais a sua própria natureza psíquica. Ao produzir uma nova atividade, o homem tinha diante de si novas necessidades, novas capacidades e novas formas de conduta; o homem pôde, em última análise, experimentar novas formas de estar no mundo, de se relacionar com os outros e consigo mesmo.

Essa importante modificação nas formas do homem ser e estar no mundo, só pôde se realizar porque as diferentes necessidades humanas que foram surgindo ou sendo elaboradas pelo próprio homem, puderam ser concretizadas em objetos específicos. Como já mencionamos, nenhuma necessidade pode ser satisfeita em si mesma, exigindo, sempre, um determinado objeto que a possa satisfazer.

\begin{abstract}
Que o homem é um ser corpóreo, dotado de forças naturais, vivo, efetivo, objetivo, sensível significa que ele tem objetos efetivos, sensíveis como objeto de seu ser, de sua manifestação de vida, ou que ele pode somente manifestar sua vida em objetos sensíveis efetivos. É idêntico: ser objetivo, natural, sensível e ao mesmo tempo ter fora de si objeto, natureza, sentido, ou ser objeto mesmo, natureza, sentido para um terceiro. A fome é uma carência natural; ela necessita, por conseguinte, de uma natureza fora de si, de um objeto fora de si, para se satisfazer, para se saciar. A fome é a carência confessada de meu corpo por um objeto existente fora dele, indispensável à sua integração e externação essencial (MARX, 2004, p.127, grifos do autor).
\end{abstract}

Esta relação manifesta-se tanto para as necessidades não-naturais quanto para as necessidades que foram culturalizadas. A fome, por exemplo, segue sendo uma necessidade natural no homem, mas ela não mais existe em sua forma estritamente natural, posto que o objeto que a satisfaz, já há muitos milhares de anos, é um objeto cultural. Desde que o homem passou a modificar o objeto que satisfaria a sua fome (cozinhando a carne, por exemplo), desde que deixou de simplesmente recolher da natureza o objeto capaz de satisfazer a sua fome, este objeto deixou de ser inteiramente natural e, conseqüentemente, a necessidade a ele atrelada também passou a ser uma necessidade culturalizada. O objeto, portanto, direciona a forma como a necessidade será satisfeita e objetivada; ou torna concreta uma necessidade abstrata.

A mesma relação necessidade/objeto pode ser pensada para a relação conduta humana/objeto. Uma nova capacidade não surgiu no homem porque as capacidades orgânicas 
a ela vinculadas se aprimoraram. Ao adquirir novas maneiras de ver e ouvir, isto não significa que sugiram nos homens refinamentos de suas capacidades sensoriais, mas sim que surgiram novas realidades sociais, novos objetos sociais, produzidos pelo próprio homem, que permitiram às capacidades orgânicas se transformarem e se tornarem capacidades propriamente humanas.

[é] apenas pela riqueza objetivamente desdobrada da essência humana que a riqueza da sensibilidade humana subjetiva, que um ouvido musical, um olho para a beleza da forma, em suma, as fruições humanas todas se tornam sentidos capazes, sentidos que se confirmam como forças essenciais humanas, em parte recém cultivados, em parte recém engendrados. Pois não só os cinco sentidos, mas também os assim chamados sentidos espirituais, os sentidos práticos (vontade, amor, etc) numa palavra o sentido humano, a humanidade dos sentidos, vem a ser primeiramente pela existência do seu objeto, pela natureza humanizada (MARX, 2004, p.110, grifo do autor).

O olho tornou-se olho humano quando o seu objeto se tornou objeto social humano, vindo do homem e destinado ao homem (MARX; ENGELS, 1980, p. 23).

É, portanto, nessa relação entre produção/apropriação de objetos culturais que o homem se formou enquanto homem cultural, com capacidades e condutas culturais. $\mathrm{O}$ pensamento estético-artístico, como um modo específico do pensamento teórico (que já é uma função psicológica essencialmente cultural), desenvolveu-se na humanidade como produto das obras artísticas, incluindo aí não apenas a obra em si mesma, mas também os instrumentos e técnicas para as produzir e apreciar: o processo mesmo de sua produção ou a atividade que lhe deu origem.

Neste sentido, para que cada sujeito forme as bases do pensamento estético-artístico, faz-se necessário que ele se aproprie dos objetos historicamente atrelados a este pensamento, por meio da reprodução das atividades artísticas que criaram tais objetos.

As aquisições do desenvolvimento histórico das aptidões humanas não são simplesmente dadas aos homens nos fenômenos objetivos da cultura material e espiritual que os encarnam, mas são aí apenas postas. Para se apropriar destes resultados, para fazer deles as suas aptidões, "os órgãos da sua individualidade", a criança, o ser humano, deve entrar em relação com os fenômenos do mundo circundante através de outros homens, isto é, num processo de comunicação com eles. Assim, a criança aprende a atividade adequada. Pela sua função este processo é, portanto, um processo de educação. (LEONTIEV, 1978, p. 290, grifo do autor).

A argumentação de Leontiev parece deixar claro que não se trata, portanto, de uma simples “posse” dos objetos culturais, para que os mesmos resultem em uma mudança em 
nossas capacidades e condutas. Os objetos materiais e não materiais relacionados à arte contêm, apenas em termos de possibilidade, as formas de conduta relacionadas ao pensamento teórico, especificamente, ao pensamento estético-artístico. Para que esse tipo de pensamento possa, de fato, ser internalizado, o sujeito deve realizar uma atividade que reproduza as características essenciais da atividade artística em questão. Tal ato, por sua vez, só pode se dar mediante a colaboração de indivíduos mais experientes, posto que os significados sociais contidos nos objetos, nas atividades humanas, só podem ser revelados em uma atividade coletiva (social).

\subsection{A função da Arte}

O homem em particular e a humanidade em geral, possuem como medida de riqueza, em uma concepção marxiana de mundo, as dimensões de necessidade e de relações com o mundo. Quanto mais diversificadas e verdadeiramente humanas forem as necessidades, mais rico será o homem. Da mesma forma, tanto mais rico ele será quanto mais amplos forem as formas e os tipos de relações que estabelece com o mundo.

Existem, portanto, diferentes tipos de relações do homem com o mundo, as quais se foram forjando e refinando no curso de seu desenvolvimento histórico-social: relações prático-utilitárias com as coisas; relação teórica; relação estética etc. Em cada uma destas relações, modifica-se a atitude do sujeito para com o mundo, já que se modifica a necessidade que a determina, e modifica-se, por sua vez, o objeto que a satisfaz (VAZQUEZ, 1968, p.55).

Marx, de acordo com este mesmo autor, em suas reflexões sobre a estética e a arte, realizadas, sobretudo, nos Manuscritos econômico-filosóficos de 1844 (MARX, 2004), compreendeu a estética como sendo uma relação peculiar entre o homem e a realidade. A estética foi se forjando histórica e socialmente no processo de transformação da natureza e criação de um mundo de objetos humanos. O surgimento da estética, como o surgimento de novas necessidades e novas formas do homem se relacionar com o mundo, é, assim, uma medida de sua riqueza.

Como já discutimos, a arte e os objetos artísticos não buscam concretizar uma necessidade prático-utilitária. Contudo, esta afirmação não pode ser interpretada como se esse tipo específico de atividade humana fosse desinteressada ou carente de necessidades. A arte 
não apenas possui uma finalidade ou necessidade, como a possui em termos estritamente humanos. “A utilidade da obra artística depende de sua capacidade de satisfazer não uma necessidade material determinada, mas a necessidade geral que o homem sente de humanizar tudo quanto toca, de afirmar sua essência e de se reconhecer no mundo objetivo criado por ele”. (VAZQUEZ, 1968 p.71).

Deste modo, a finalidade da arte encontra-se na satisfação da necessidade que os homens possuem de afirmarem a sua essência humana em um objeto concreto-sensível, isto é, responde à necessidade humana de se exteriorizar ou objetivar-se. A arte, a partir de suas criações, busca ampliar e enriquecer a realidade já humanizada pelo trabalho humano; ela é um meio de auto-afirmação ou autoconhecimento do homem no mundo.

O homem se eleva, se afirma, transformando a realidade, humanizando-a, e a arte com seus produtos satisfaz essa necessidade de humanização. Por isso não há - nem pode haver - "arte pela arte”, mas arte por e para o homem. Dado que este é, por essência, um ser criador, cria os produtos artísticos porque neles se sente mais afirmado, mais criador, isto é, mais humano. (VAZQUEZ, 1968, p 48).

Reiterando: a arte cria uma nova realidade (a obra artística ou o objeto artístico) a partir da realidade concreta. Esta nova realidade cumpre a função de suprir uma utilidade e necessidade subjetiva, historicamente elaborada pelo homem, qual seja, a necessidade de expressar o humano em toda a sua plenitude.

Como um tipo específico de atividade humana e, mais do que isso, como uma forma específica do trabalho humano (portanto como uma atividade que expressa a dimensão ou essência criadora do homem), a arte não é simples imitação ou reprodução do concreto real. Evidentemente ela deve partir deste concreto real, mas deve também ir além dele, criando o “concreto artístico” (VAZQUEZ, 1968). O artista toma parte de uma atividade essencialmente criadora; ele não elabora uma obra artística simplesmente copiando o real, mas justamente criando uma outra realidade a partir desse real. Em outros termos, o artista cria a sua obra a partir e com os elementos advindos da realidade concreta, mas compõe ou organiza estes elementos de um modo particular, de um modo a criar uma outra realidade: a artística.

A criação de uma nova realidade na atividade artística, não pode ser compreendida como uma simples necessidade do novo, do inédito, no sentido de um vanguardismo. A arte, muitas vezes, acaba criando novas tendências, mas a questão central é a criação de uma nova realidade - não necessariamente “inédita”- via a atividade artística, realidade esta correspondente à necessidade humano genérica que a arte possui: exteriorizar o humano nos 
objetos (caso dos artistas) e apropriar-se do humano com os objetos (caso do público). A obra artística, como uma realidade criada, uma nova realidade, consegue explicitar determinadas verdades sobre a realidade humana dos homens concretos, dos sujeitos que vivem em uma determinada sociedade, sob certas relações humanas. "A arte só é conhecimento na medida em que é criação. Tão somente assim pode servir à verdade e descobrir aspectos essenciais da realidade humana”. (VAZQUEZ, 1968, p.36).

Uma vez que a obra artística possui esta capacidade de revelar determinados aspectos essenciais da realidade (ainda que seja da realidade especificamente humana), deveríamos ou poderíamos aproximar a arte a uma função cognoscitiva? E se assim o fizermos, se reconhecermos essa dimensão da arte, estaríamos a aproximando da ciência ou da filosofia?

A arte, como síntese da experiência das gerações passadas e forma de objetivação de uma parte da cultura, carrega em si uma dimensão universal da experiência humana. Assim como a ciência, a arte permite ao homem o acesso a diversas experiências que, individualmente, em sua vida e através de sua experiência direta, ele não poderia obter. Trata-se da possibilidade do homem identificar-se com a vida de outros, de incorporar em si aquilo que ele não é, mas que tem a possibilidade de vir a ser.

\begin{abstract}
Por isso, assim como a linguagem representa em cada indivíduo a acumulação de milênios de experiência coletiva, assim como a ciência equipa cada indivíduo com o conhecimento adquirido pelo conjunto da humanidade, da mesma forma a função permanente da arte é recriar para $a$ experiência de cada indivíduo a plenitude daquilo que ele não é, isto é, a experiência da humanidade em geral. (FISCHER, 1976, p.252, grifo do autor).
\end{abstract}

A arte, a linguagem e a ciência não sintetizam um campo da experiência humana em geral. Cada uma, e a despeito de pertencerem à atividade humana em geral, sintetizam um campo específico do psiquismo social. No caso da arte, e como uma primeira leitura de sua função, seu campo é o dos sentimentos (VIGOTSKI, 2001). Neste sentido, assim como as técnicas, enquanto ferramentas, são capazes de prolongar os braços dos homens, a arte também cumpre esse papel de signo: ela é uma espécie de "sentimento social prolongado, ou uma técnica de sentimentos [...]” (VIGOTSKI, 2001, p.308). Trata-se, portanto, de um instrumento da sociedade que incorpora, no ciclo da vida social, os aspectos mais íntimos e pessoais de nosso ser. ${ }^{14}$

\footnotetext{
${ }^{14}$ Pensamos que essa aproximação da arte com o campo do sentimento possa ser uma forma de leitura da dimensão fundamental que tem o particular dentro da arte. Esta questão ainda precisará de maiores reflexões.
} 
Esse posicionamento afasta-se de uma idéia subjetivista do sentimento, em que o mesmo seria fundamentalmente individual para, depois, passar para o plano social. O processo é justamente o oposto. O sentimento dos indivíduos não se torna social, mas ao contrário, torna-se pessoal. Ao vivenciarmos uma obra de arte, fazemos nossos aqueles sentimentos que sintetizam um conjunto de experiências humanas no campo dos sentimentos e, assim, convertemos em pessoal àquilo que é social (VIGOTSKI, 2001).

A arte é social em nós, e, se o seu efeito se processa em um indivíduo isolado, isto não significa de maneira nenhuma, que as suas raízes e essência sejam individuais. É muito ingênuo interpretar o social apenas como coletivo, como a existência de uma multiplicidade de pessoas. O social existe até onde há apenas um homem e as suas emoções pessoais. Por isso, quando a arte realiza a catarse ${ }^{15}$ e arrasta para esse fogo purificador as comoções mais íntimas e mais vitalmente importantes de uma alma individual, o seu efeito é um efeito social. A questão não se dá da maneira como representa a teoria do contágio, segundo a qual o sentimento que nasce em um indivíduo contagia a todos, torna-se social; ocorre exatamente o contrário. A refundição das emoções fora de nós realiza-se por força de um sentimento que foi objetivado, levado para fora de nós, materializado $e$ fixado nos objetos externos da arte, que se tornaram instrumento da sociedade. A peculiaridade essencialíssima do homem, diferentemente do animal, consiste em que ele introduz e separa de seu corpo tanto o dispositivo da técnica quanto o dispositivo do conhecimento científico, que se tornaram instrumentos da sociedade. De igual maneira, a arte é uma técnica social do sentimento, um instrumento da sociedade através do qual incorpora ao ciclo da vida social os aspectos mais íntimos e pessoais do nosso ser. Seria mais correto dizer que o sentimento não se torna social, mas, ao contrário, torna-se pessoal, quando cada um de nós vivencia uma obra de arte, converte-se em pessoal sem com isto deixar de continuar social (VIGOTSKI, 2001, p.315, grifo nosso).

É evidente que o que sinto, que meus sentimentos de maneira geral, são absolutamente pessoais. A argumentação aqui não despreza, de modo algum, este fato. A questão que se quer ressaltar é a de que quaisquer sentimentos que eu tenha são fruto, de uma forma ou de outra, conscientemente ou não, de minha apropriação desse sentimento desenvolvido pela humanidade. Quando um bebê nasce, e a despeito de suas múltiplas e variadas reações sensíveis ao mundo, ele ainda não possui sentimentos. Uma criança pequena tem que aprender o que são as sensações que sente e, ao aprender, aprende de um modo específico, de um modo já humanizado: em forma de sentimentos. Meu sentimento de raiva, de amor, de solidariedade etc, embora sejam pessoais não são individuais, porque são sentimentos que a humanidade desenvolveu e dos quais tive que me apropriar, inclusive para saber lidar com eles e controlar

\footnotetext{
${ }^{15} \mathrm{O}$ conceito de catarse é um conceito de certa forma nuclear na teoria vigotskiana da arte, mas neste trabalho não nos debruçaremos sobre ele.
} 
as minhas próprias condutas. Mas tais sentimentos são efetivamente pessoais, porque ao me apropriar deles, crio um modo específico de me relacionar com eles. O papel que um sentimento possa ter em minha vida ou o sentido que atribuo a ele é, este sim, pessoal, sem, contudo, como diz Vigotski, deixar de ser social.

A arte, como um modo específico do homem se relacionar com o mundo, consigo mesmo e com os outros homens, representa ou possui uma forma também específica de conhecimento do mundo; ela possibilita um maior conhecimento da realidade mas o faz por vias específicas.

Verifica-se, pois, que a poesia ou a arte são um modo específico de pensamento, que acaba acarretando o mesmo que o conhecimento científico acarreta [...] só que o faz por outras vias. A arte difere da ciência apenas pelo seu método, ou seja, pelo modo de vivenciar, vale dizer, psicologicamente (VIGOTSKI, 2001, p.34).

Diante desta argumentação, pode-se compreender que a arte não possuiria um conteúdo próprio. Ela trabalharia com os mesmos conteúdos ou conhecimentos da ciência, tendo como especificidade apenas os seus métodos de aproximação do real. Analisando outros autores, que também defendem que a especificidade da arte, enquanto conhecimento do mundo reside, sobretudo, em sua forma e não em seu objeto ou conteúdo, (a arte refletiria a realidade por meio de imagens, ao passo que a ciência e a filosofia o fariam por meio de conceitos), Vázquez (1968, pp 34/35) faz as seguintes considerações:

Pois bem; se a arte e a ciência são formas distintas de conhecimento, que sentido tem essa duplicação da função cognoscitiva? Para que serve este novo conhecimento que, na verdade, não enriquece o que já possuímos do objeto, mas pura e simplesmente a nossa forma de conhecer?

$[\ldots]$

Pois bem; se a arte como forma de conhecimento corresponde a uma necessidade, e não é uma mera duplicação - mediante, imagens, parábolas ou símbolos - do que a ciência e a filosofia - mediante conceitos - já nos dão, ela só se justifica se tiver um objeto próprio e específico, como assinala Burov, que condiciona, por sua vez, a forma específica do reflexo artístico. Este objeto específico é o homem, a vida humana.

Ao ressaltar o humano ou a vida humana como o objeto da atividade artística, que para além de seus métodos o diferencia do tipo de conhecimento produzido por outras atividades -

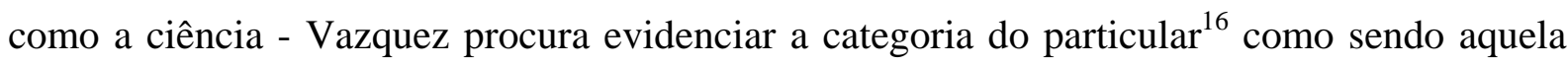

\footnotetext{
${ }^{16}$ Lucaks defende e desenvolve essa idéia em seu livro Introdução a uma estética marxista, 1978.
} 
central na relação estética do homem com o mundo. Na arte, a realização da dimensão universal do humano não ocorre mediante um universal abstrato, mas sim a partir de "um universal humano que surge no e pelo particular” (VAZQUEZ, 1968 p.28).

Uma obra artística não apresenta a relação humana apenas em sua generalidade, mas sim e, fundamentalmente, em suas manifestações individuais. "Apresenta homens concretos, vivos, na unidade e riqueza de suas determinações, nos quais se fundem de um modo peculiar o geral e o singular” (idem, p.35).

A ciência, para poder explicitar a realidade em forma de conhecimento objetivo, tende a secundarizar ou mesmo a negar a subjetividade; a marca do sujeito, suas idéias, aspirações ou esperanças precisam ser "ocultadas" no objeto científico, nas verdades, teorias, leis ou conceitos. A arte, ao explicitar essa dimensão do sujeito, o faz de modo que essa dimensão do singular esteja em íntima e específica relação com o geral ou o universal. A dimensão do singular assegura o desenvolvimento de seu conteúdo específico, ao passo que a dimensão do universal assegura a sua condição de objeto da humanidade e não apenas de objeto de um indivíduo.

Na criação artística, ou relação estética criadora do homem com a realidade, o subjetivo se torna objetivo (objeto), e o objeto se torna sujeito, mas um sujeito cuja expressão já objetivada não só supera o marco da subjetividade, sobrevivendo a seu criador, como pode ser compartilhada, quando já fixada no objeto, por outros sujeitos (VAZQUEZ, 1968, p.56).

Assim, defende-se a idéia de que o homem seja o objeto específico da arte, ainda que não seja sempre ou necessariamente o objeto da representação artística. Os objetos "não humanos” não são representados como objetos em si mesmos, mas sempre em sua relação com o homem, isto é, naquilo que são para o homem: como objeto humanizado. Neste sentido, o objeto representado carrega uma significação social de um mundo humano, bem como uma significação social da atividade humana (artística) encarnada nele. 


\section{A ARTE E O PENSAMENTO TEÓRICO}

Considerando todas as especificidades já mencionadas na relação arte e conhecimento, iremos agora abordar a relação da arte com o pensamento teórico. O pensamento teórico, como uma das funções psíquicas superiores, como uma das formas específicas da conduta cultural do homem, só pode ser formado no sujeito mediante a sua relação/apropriação de um objeto que encarne, em si, o pensamento teórico. Diferentes objetos podem conter as bases do pensamento teórico, o que direciona a sua formação em determinados sentidos. Os objetos artísticos, por exemplo, carregam tanto uma singularidade do pensamento teórico (formando o que estamos chamando neste trabalho de pensamento estético-artístico), quanto uma generalidade do mesmo. Neste capítulo, trabalharemos tanto com essa dimensão universal do pensamento teórico, quanto com sua manifestação particular na atividade artística.

\subsection{O pensamento teórico}

Como o homem conhece o mundo? Podemos dizer que existe um conhecimento mais preciso ou mais próximo da realidade e, assim, uma certa hierarquia de saberes? Em outros termos: existe um tipo de conhecimento que consiga explicar de forma mais completa uma realidade ou fenômeno, que consiga compreender mais e melhor esta realidade, ou o que temos são sempre conhecimentos parciais, conhecimentos que dão conta de um ou alguns aspectos da realidade, mas nunca da realidade como um todo? E, relacionado a estas questões: é possível que cada sujeito em particular, e a humanidade em geral, conheça a realidade em seus múltiplos aspectos ou em sua essência?

Qualquer conhecimento sobre a realidade é sempre um ato de generalização (VIGOTSKI, 2009). Produzir um conhecimento, portanto, implica, de uma forma ou de outra, em generalizar a experiência particular vivida em determinada realidade. Para pensarmos sobre esse processo de generalização da realidade e para pensarmos se este processo é único ou se temos tipos diferentes de generalizações, analisaremos um exemplo retirado de nossas vidas cotidianas: a relação uso de cobertor/ sensação de frio.

Uma criança que utiliza o cobertor para não sentir frio possui um determinado conhecimento sobre essa realidade e elabora uma determinada generalização sobre a relação 
frio/cobertor, possível de ser expressa em palavras: "uso o cobertor porque ele é quente”; ou “uso o cobertor porque ele me aquece”. A generalização alcançada por essa criança refere-se a sua percepção e a uma dedução obtida de suas experiências cotidianas com o uso do cobertor. Ela sabe que ao utilizar o cobertor não passará frio e, assim, pôde elaborar um conhecimento ou uma generalização sobre esse fenômeno.

Um físico, do mesmo modo que a criança, utiliza o cobertor para não passar frio e possui, assim como ela, um determinado conhecimento sobre essa realidade; possui uma determinada generalização sobre ela. Entretanto, o conhecimento elaborado pelo físico deu-se não só pela experiência particular que teve com o uso do cobertor em sua vida, ou na vida de pessoas próximas a ele, mas principalmente pelos conhecimentos que obteve através de seus estudos sobre os processos de trocas de calor entre os corpos, o que lhe permitiu elaborar o conhecimento sobre a relação não passar frio/cobertor. O conhecimento desse físico, assim como o da criança, também poderia ser expresso em palavras: "Eu utilizo o cobertor porque ele faz com que o calor produzido pelo meu corpo fique entre o cobertor e meu corpo, mantendo este local com essa temperatura”.

Criança e adulto, neste exemplo, demonstram um conhecimento sobre a mesma realidade. Ambos generalizam a realidade para construírem o seu conhecimento. Mas o que parece bastante evidente neste exemplo é que o tipo de generalização de um e de outro, é distinto. A forma de se aproximarem da realidade para explicá-la é diferente, tanto em seu processo quanto em seu produto. Poderíamos colocar as seguintes questões aqui: a) o que caracteriza a diferença entre o tipo de generalização da criança e do físico em nosso exemplo? b) podemos dizer que o conhecimento de um expressa de forma mais elaborada a realidade que o conhecimento do outro?

Como dissemos, a criança e o físico não apenas produziram um conhecimento diferente sobre uma mesma realidade, como percorreram caminhos distintos para chegarem a esses conhecimentos. A criança generalizou a relação frio/cobertor a partir de suas próprias vivências com este fenômeno. O processo de elaboração do conhecimento da criança, portanto, centrou-se em sua experiência empírica. O físico generalizou a relação frio/cobertor a partir das experiências de outros sujeitos que analisaram as relações de trocas de calor entre os corpos e as sintetizaram. O processo de elaboração do conhecimento do físico, portanto, centrou-se na experiência teórica produzida pela humanidade sobre essa relação. Deste modo, o que caracteriza a diferença dos tipos de generalizações entre um e outro é a forma de aproximação da realidade: uma é empírica, a outra é teórica. Essas duas formas de 
generalização serão posteriormente aprofundadas por nós. Por enquanto, pontuamos a sua existência.

Reconhecendo, então, que o conhecimento da criança sobre a relação frio/cobertor é um conhecimento de tipo empírico e que o conhecimento do físico é um conhecimento de tipo teórico, poderíamos analisar a segunda questão proposta por nós que, inclusive, articula-se às questões elaboradas no primeiro parágrafo deste tópico: há uma distinção de qualidade entre um tipo de conhecimento e o outro?

Saber que o cobertor não "produz calor" ou poder compreender que a sua função para nos proteger do frio decorre do fato dele manter o calor produzido pelo nosso próprio corpo, significa não apenas uma forma diferente de se aproximar da realidade (comparativamente ao conhecimento que diz que o cobertor produz calor), mas efetivamente uma forma mais elaborada de conhecer essa realidade. O conhecimento teórico, que em nosso exemplo foi expresso pelo físico, representa o conhecimento que melhor se aproxima do fenômeno em questão e que permite explicar a realidade em suas múltiplas relações. O conhecimento empírico, expresso em nosso exemplo pela criança, é um conhecimento bastante próximo da realidade cotidiana (imediata) e das pessoas em geral, mas muito mais distante de explicar essa realidade em suas múltiplas relações.

Há, portanto, um tipo de conhecimento que consegue se aproximar mais e melhor da explicação da realidade e dos fenômenos dessa realidade: o conhecimento teórico. Devemos deixar claro que essa afirmativa não implica dizer que o conhecimento teórico seja mais importante para a vida do sujeito que o conhecimento espontâneo. Para as nossas vidas cotidianas e para não passar frio durante uma noite de baixas temperaturas, é suficiente termos uma generalização empírica sobre a relação frio/cobertor. Saber que o “cobertor me aquece”, possuir a generalização empírica sobre esse fenômeno, é plenamente suficiente para eu não passar frio durante a noite. Para viver a minha cotidianidade, de modo geral, basta elaborar e apropriar-me de conhecimentos empíricos sobre a realidade. Na vida cotidiana, portanto, os saberes empíricos podem ser mais decisivos que os teóricos.

Entretanto, nossas vidas não se pautam apenas na cotidianidade. Não devem ser constituídas apenas por aquilo que a cotidianidade oferece. Compreender a realidade em seus múltiplos aspectos, indo para além de sua utilidade ou aplicabilidade na vida prática, só é possível quando nos apropriamos das generalizações teóricas sobre essa realidade: as generalizações que melhor explicam a realidade em questão.

Essa afirmação e o estabelecimento da hierarquia entre os saberes empírico e teórico apresenta, no campo epistemológico e no campo educacional, dois contra argumentos. No 
campo epistemológico, argumenta-se que por mais exato e complexo que seja um determinado conhecimento, ele sempre será um conhecimento parcial ${ }^{17}$. Nenhum conhecimento pode abarcar toda a realidade que pretende explicar; nenhum conhecimento pode abarcar todos os fatos que constituem essa realidade. Neste sentido, as generalizações teóricas, por também serem um conhecimento parcial sobre a realidade, não podem ser postas num nível hierarquicamente superior às generalizações empíricas. Reconhece-se que se tratam de conhecimentos diferentes, mas essa diferença não pode ser valorada em termos qualitativos. Resumindo, nenhum conhecimento pode ser considerado mais completo que o outro; são sempre parciais.

Esse contra argumento é verídico ao afirmar que nenhum conhecimento pode abarcar todos os fatos que constituem a realidade. Porém, não é verídico ao considerar que apenas expressando todos os fatos de uma realidade é que conseguimos expressar tal realidade em sua totalidade.

\begin{abstract}
Existe uma diferença fundamental entre a opinião dos que consideram a realidade como totalidade concreta, isto é, como um todo estruturado em curso de desenvolvimento e de autocriação, e a posição dos que afirmam que o conhecimento humano pode ou não atingir a "totalidade" dos aspectos e dos fatos, isto é, das propriedades das coisas, das relações e dos processos da realidade. No segundo caso, a realidade é entendida como o conjunto de todos os fatos. Como o conhecimento humano não pode jamais, por princípio, abranger todos os fatos -pois sempre é possível acrescentar fatos e aspectos ulteriores - a tese da concreticidade ou da totalidade é considerada uma mística. Na realidade, totalidade não significa todos os fatos. Totalidade significa: realidade como um todo estruturado, dialético, no qual ou do qual um fato qualquer (classe de fatos, conjunto de fatos) pode vir a ser racionalmente compreendido. Acumular todos os fatos não significa ainda conhecer a realidade; e todos os fatos (reunidos em seu conjunto) não constituem, ainda, a totalidade (KOSIK, 2002, p.43/ 44, grifo do autor).
\end{abstract}

A generalização teórica não se distingue da generalização empírica (e, portanto, não se aproxima mais da realidade) pelo fato de aglutinar, em si, um maior número de fatos comparativamente à generalização empírica. A generalização teórica constitui-se num tipo de conhecimento mais elaborado, mais próximo da explicação da realidade, porque abarca a explicação da essência dessa realidade: da realidade como uma totalidade estruturada.

O conhecimento teórico, portanto, busca explicitar as múltiplas relações existentes em um determinado fenômeno, relações essas que não nos são diretamente acessíveis pelas vias

\footnotetext{
${ }^{17}$ Podemos citar como teorias epistemológicas vinculadas a essa idéia, e em termos gerais, as teorias vinculadas à perspectiva da pós-modernidade, que fazem a crítica a todas as tentativas de explicação da realidade ou às “metanarrativas".
} 
perceptivas, mas que, ao contrário, já são um produto de nosso pensamento (dos processos de análise e síntese teóricas) sobre essa realidade em questão.

Mais do que isso. O conhecimento teórico permite ao sujeito relacionar-se de um modo distinto com a realidade ou com o objeto a ser conhecido. Ao utilizar o conceito empírico da relação frio/cobertor tenho como objeto de minha consciência, como foco de minha ação, a necessidade de não passar frio, isto é, o fenômeno ou a realidade em si mesma. Quando utilizo o conceito teórico dessa mesma relação, o objeto de minha consciência muda: deixa de ser a realidade em si mesma para ser os conceitos sobre essa realidade. Minha ação está direcionada para a análise e síntese de conceitos relacionados ao fenômeno frio/cobertor e não para este fenômeno em si mesmo.

Um segundo contra-argumento à existência de hierarquias entre os saberes empíricos e teóricos, este no campo pedagógico, afirma que o conceito (teórico), por ser uma abstração, é uma forma de nos distanciarmos da realidade e não uma forma de nos aproximarmos dela. Esse argumento, tal qual o primeiro (no campo epistemológico), apresenta um ponto de verdade inquestionável: uma abstração é uma forma indireta de nos relacionarmos com a realidade imediata e, assim, implica num certo afastamento do sujeito em relação a essa realidade. Devemos reconhecer, portanto, que os conceitos implicam, efetivamente, em um distanciamento da realidade por parte do sujeito. Mas esse distanciamento ocorre tão somente no plano da realidade imediatamente percebida, de uma relação direta com essa realidade. A questão, então, seria sabermos se o conhecimento adquirido desta relação direta e imediata representa $o$ conhecimento mais próximo da realidade ou não.

[...] a própria essência do conceito e da generalização pressupõe, a despeito da doutrina da lógica formal, não o empobrecimento mas o enriquecimento da realidade representada no conceito em comparação com a percepção sensorial e indireta e com a contemplação dessa realidade (VIGOTSKI, 2009, p.359).

Como buscamos analisar em nosso exemplo, o conceito teórico, ao nos permitir enxergar elementos da realidade que não nos são acessíveis pela relação direta com a realidade (ou com o objeto), é uma forma que nos possibilita melhor conhecer essa realidade e, neste sentido, ao invés de nos afastar dela, nos aproxima. Em outras palavras, o conhecimento teórico nos permite conhecer de forma mais profunda a realidade, conhecê-la em suas múltiplas relações e em seu processo de desenvolvimento. 
O pensamento conceitual envolve uma enorme expansão das formas resultantes da atividade cognitiva. Uma pessoa capaz de pensamento abstrato reflete o mundo externo mais profunda e completamente e chega a conclusões e inferências a respeito do fenômeno percebido, tomando por base não só a sua experiência pessoal, mas também esquemas de pensamento lógico que objetivamente se formam em um estágio avançado do desenvolvimento da atividade cognitiva (LURIA, 2005, p.135).

Desconsiderar esse fato e, mais do que isso, defender que a relação teórica do sujeito com o mundo seja uma relação mais distante da realidade, implica em um posicionamento pedagógico bastante grave: a desvalorização do trabalho com os tipos teóricos de generalização na escola; a desvalorização dos conhecimentos mais elaborados pela humanidade como objeto do trabalho escolar. A defesa de que o ensino precisa ser organizado de forma cada vez mais próximo da criança nos parece correta. Mas ao considerar a proximidade em termos empíricos e não concreto $^{18}$ e ao compreender a realidade da criança apenas em sua dimensão particular (e não universal), esse posicionamento implica em organizar o ensino de forma cada vez mais articulada com as generalizações de tipo empírico, próprias à vida cotidiana dos sujeitos.

Quais as implicações de um tipo de formação escolar, centrado no conhecimento empírico, para o desenvolvimento das crianças? Se à escola não cabe trabalhar com esses tipos de generalizações, se à escola não cabe formar nas crianças (ao menos prioritariamente) o pensamento vinculado às generalizações teóricas, a quem caberia, em nossa atual sociedade, realizar esse tipo de formação? Ou será que vivemos em um momento histórico em que esse tipo de formação pode ser efetivamente secundarizado nas futuras gerações?

Davidov (DAVYDOV, 1982; DAVIDOV; 1988) analisa a especificidade e a distinção entre essas duas formas de conhecimento sobre o mundo, o conhecimento empírico e o conhecimento teórico, e traz questões importantes para pensarmos sobre o papel de cada uma delas na formação dos sujeitos e sobre a função da escola com relação ao ensino de conceitos. Cada uma dessas formas de conhecimento está relacionada a um tipo específico de pensamento e consciência, respectivamente o pensamento empírico e o pensamento teórico.

Como já afirmamos, o pensamento, de uma maneira geral, já é uma forma do homem concretizar a sua relação mediada com o mundo. Deste modo, tanto o pensamento empírico, quanto o teórico, permitem superar a relação direta do homem com a realidade. Mais do que simplesmente “agregar conhecimentos” ou informações, a apropriação do pensamento (tanto

${ }^{18}$ O concreto é compreendido na teoria marxiana como sendo a síntese de múltiplas determinações, um produto do pensamento que caminha do "concreto caótico" (ou empírico) para o concreto/concreto pensado, mediado pelas abstrações. 
o empírico quanto o teórico) implica na apropriação de um modo de ação, de um modo de estar e lidar com o mundo. Neste sentido, ambas as formas de pensamento são mentais ou psíquicas. O conhecimento empírico não é equivalente a um conhecimento perceptivo, muito menos a um simples conhecimento prático (“saber fazer” ou tentativa e erro). O que distingue o pensamento empírico do pensamento teórico é o modo como a realidade é analisada e transformada em conhecimento e não o fato de se ter ou não um conhecimento abstrato.

O conhecimento empírico traduz um tipo de análise da realidade em que as condições aparentes dos objetos ou fenômenos, ou as suas características mais diretamente observáveis, ou possíveis de serem remetidas à observação são ressaltadas, comparadas entre si e sintetizadas em um conceito: o conceito empírico. O conhecimento teórico, por outro lado, busca analisar as condições internas do objeto ou fenômeno, as relações entre as relações, ou seja, as relações que ele estabelece com os demais objetos e fenômenos e com o seu próprio processo de formação. Tais “relações das relações” são também analisadas e sintetizas em forma de um conceito: o conceito teórico.

Deste modo, além de nos apropriarmos de conhecimentos distintos (caso dos conceitos analisados no exemplo da relação frio/cobertor) nos apropriamos, fundamentalmente, de um modo distinto de pensar e de lidar com o mundo; nos apropriamos de ações do pensamento, de formas de análise e síntese da realidade, distintas. Davidov (DAVYDOV, 1982; DAVIDOV, 1988) afirma que a formação do pensamento teórico requer a apropriação de um conhecimento também teórico, porque nessas objetivações estão contidas já, em forma de síntese, um modo de ação do pensamento.

Como síntese desse debate e forma de avançarmos nas discussões sobre a formação do pensamento teórico e a relação deste com a atividade criadora ou imaginadora dos sujeitos podemos apontar as seguintes considerações:

a) O pensamento teórico permite uma relação substancialmente diferente do homem com a realidade (comparativamente ao pensamento empírico) e deve ser desenvolvido em cada ser singular, porque contribui para ampliar as suas relações humanas e, neste sentido, entra na sua medida de riqueza humana;

b) O pensamento empírico é típico da vida cotidiana: desenvolve-se espontaneamente nela e é suficiente para que o homem viva a sua cotidianidade. O pensamento teórico, por sua vez, não sendo próprio à vida cotidiana e não podendo ser desenvolvido espontaneamente nela, precisa de meios específicos e intencionais para sua formação. Esses meios e essa intencionalidade devem ser encontrados e desenvolvidos, em nossa sociedade, prioritariamente na escola. 


\subsection{O processo de formação de conceitos.}

À afirmação geral de que a criança deve aprender na escola, devemos passar à qualificação dessa afirmação defendendo a especificidade de qual tipo de aprendizado deve se dar na escola. A escola é local e momento da criança aprender um tipo particular de conhecimento: os conhecimentos teóricos ou científicos. É apropriando-se deles, que os estudantes poderão desenvolver um tipo específico de pensamento e de atividade, respectivamente, o pensamento teórico e a atividade teórica.

A defesa da finalidade da escola como sendo a de transmitir esses conhecimentos mais elaborados pela humanidade é bastante criticada e soa como algo um tanto anacrônico em a nossa sociedade contemporânea. A esta crítica, devemos fazer duas considerações.

A primeira delas refere-se à crescente utilização de adjetivos postos após as palavras conhecimento, conceito ou verdade e que visam a relativizar a sua substantividade, o seu significado. O conhecimento, o conceito e as verdades produzidas por meio da atividade humana, são, então, qualificados como produtos voláteis. Assim, temos conceitos “tidos como verdadeiros"; conhecimentos “supostamente superiores” etc. Essa relativização do saber não se aproxima a uma relatividade histórica, isto é, não procura apreender a provisoriedade dos conhecimentos de acordo com o movimento histórico do desenvolvimento do próprio objeto a ser conhecido. A relativização feita por autores e correntes teóricas vinculadas (de forma mais ampla) ao pensamento pós-moderno é uma relativização em termos absolutos. Ao quererem superar a existência de conhecimentos ou verdades absolutas (imutáveis) e por buscarem essa superação fora dos marcos da historicidade da produção do conhecimento, acabam caindo num outro tipo de absolutização: o da relatividade absoluta e da volatização de qualquer conhecimento produzido. Rigorosamente, para eles, os conhecimentos explicam um aspecto da realidade e um aspecto bem localizado no tempo e no espaço, tomados de modo independentes entre si. Daí do seu caráter específico e provisório e de nossa impossibilidade de compararmos e hierarquizarmos os conhecimentos.

Como já discutimos no tópico anterior, nos posicionamos contrários a esse tipo de relação com o conhecimento e nisso não vemos nada de anacrônico. Pelo contrário. Ao defendermos a necessidade premente da escola trabalhar com aqueles conhecimentos mais elaborados produzidos pela humanidade e de buscar formar um tipo específico de pensamento nos estudantes (que dificilmente pode ser formado em nossa atual vida cotidiana), estamos afirmando uma necessidade bastante atual: a de garantir as máximas possibilidades de humanização para cada sujeito. Os conhecimentos não são apenas tidos como verdadeiros, 
mas são efetivamente verdadeiros, representando as máximas possibilidades de compreendermos um determinado fenômeno ou realidade, em um determinado momento histórico.

A segunda consideração refere-se ao debate mais específico sobre o processo de formação dos conceitos que faremos neste tópico. Quando a crítica ao posicionamento da escola como local e tempo de transmissão dos saberes mais elaborados não é feita por vias epistemológicas, é feita por vias pedagógicas e/ou psicológicas. A afirmação e a utilização da palavra transmissão seria um posicionamento contrário à defesa do sujeito como ser ativo no seu processo de conhecimento, além de negar a ação criativa dos sujeitos ao transformar o ensino em um mero processo de memorização dos saberes historicamente produzidos.

Pensamos que ao desenvolver o processo de formação dos conceitos, objetivo deste tópico, essa crítica poderá ser percebida como infundada. Entretanto, vamos nos adiantar e colocar em forma de “teses” duas afirmações:

a) Para que o estudante seja um sujeito ativo no seu processo de aprendizagem escolar, é necessário que o ensino seja organizado para esse fim. Espontaneamente, isto é, fora de uma organização intencional da atividade de ensino e aprendizagem, o sujeito pode ser ativo no seu processo de aprendizagem espontânea, mas dificilmente será ativo no seu processo de aprendizagem dos conhecimentos escolares (conhecimentos teóricos).

b) Transmitir conhecimentos aos estudantes não é sinônimo, em termos absolutos, de organização de um ensino mecânico. Ainda que em um momento da história essa associação tenha se dado (ex: a pedagogia tradicional), a defesa da centralidade do conhecimento - como objeto central de ensino e da aprendizagem escolar - não nos remete de forma incondicionada a um ensino mecânico e memorístico, mas sim e de forma incondicional, a um ensino planejado que vise à apropriação desses saberes pelos educandos.

Passaremos, agora, a analisar os mecanismos específicos no processo de formação dos conceitos (empíricos e teóricos).

Há uma crítica bastante pertinente ao ensino conceitual que se dá de forma mais ou menos recorrente nas situações de ensino escolar: o ensino memorístico do conceito. Mas essa crítica relaciona-se menos com a natureza do conceito (ele deve ser memorizado para ser aprendido) e mais com um posicionamento pedagógico (deve-se memorizar os conceitos para os aprender). 
conceitos propriamente ditos e já constituídos na criança, que é possível o trabalho direto com o conceito no processo de ensino escolar. Mas como mostra a pesquisa, este trabalho não é o fim mas o início do desenvolvimento do conceito científico, e não só não exclui os processos propriamente ditos de desenvolvimento como lhes dá uma nova orientação e coloca os processos da aprendizagem e desenvolvimento em novas relações maximamente favoráveis do ponto de vista dos objetivos finais da escola (VIGOTSKI, 2009, p.251, grifo nosso).

Trabalhar com definições conceituais na escola não é um problema em si mesmo. Pelo contrário, é um elemento sumamente importante no processo de formação de novos conceitos. A questão reside mais no papel e no momento do ensino em que essas definições são utilizadas do que no questionamento de sua necessidade. Evidentemente, o ensino como “falação apenas do conceito” ou como “verbalismo”, remete-nos a uma aprendizagem mecânica e desprovida de sentido para a maioria dos estudantes.

Em tais casos a criança não assimila o conceitos mas a palavra, capta mais de memória que de pensamento e sente-se impotente diante de qualquer tentativa de emprego consciente do conhecimento assimilado. No fundo, esse método de ensino de conceitos é a falha principal do rejeitado método puramente escolástico de ensino, que substitui a apreensão do conhecimento vivo pela apreensão de esquemas verbais mortos e vazios (VIGOTSKI, 2009 p.247).

Reconhecer isso não é o mesmo que reconhecer "o erro” em se trabalhar com as definições conceituais na escola. Dizer isso, não é o mesmo que rechaçar as falas do professor que buscam sintetizar um determinado conceito e os apresentar para os estudantes. Não está vedado ao professor (e na verdade nos parece ser um momento imprescindível do ensino) que ele mesmo realize alguns processos de sínteses de modo a ajudar os estudantes em seus próprios processos de síntese conceitual. O professor jamais poderá fazer a síntese pela criança, posto que o processo de desenvolvimento de um conceito (ou função psíquica) é pessoal. Mas ele pode e deve ajudar a criança a chegar a esse processo de síntese, uma vez que esse processo de desenvolvimento, ainda que seja estritamente pessoal, é, também, absolutamente social (coletivo).

A definição de um conceito, a explicitação de seu significado para a criança, não é o mesmo que o aprendizado deste conceito, isto é, não é o ponto de chegada do processo de ensino. Como diz Vigotski (2009, p.250) “[...] no momento em que a criança toma conhecimento pela primeira vez do significado de uma nova palavra, o processo de desenvolvimento dos conceitos não termina, mas está apenas começando”. Essa compreensão nos parece sumamente importante para pensarmos na organização do ensino. 
Compreendermos que o próprio significado do conceito evolui, e que sua apropriação não marca o ponto de chegada do desenvolvimento de um conceito, mas do contrário, e muitas vezes, apenas o ponto de partida, nos proporciona outra relação com o trabalho de ensino dos conceitos.

A definição do conceito, ou a explicitação do seu significado é importante e fundamental no processo de aprendizagem do mesmo. Mas sua importância não reside no fato de fornecer o conceito em sua forma acabada à criança (o que, como diz Vigotski é impossível). Os adultos podem e devem ajudar a criança a desenvolver os conceitos, mas não podem fornecer a elas os conceitos prontos, em sua forma acabada. Não podem transmitir à criança o seu modo de pensamento, embora possam e devam organizar aprendizagens para que se apropriem dessas formas de pensamento.

Quando um estudante ouve (e inclusive memoriza) uma determinada síntese conceitual, uma determinada definição de um conceito, ele não se apropriou, necessariamente, do próprio conceito em questão. O conceito, como síntese de múltiplas relações, ocorrerá em um momento posterior ao contato inicial com a definição conceitual e seu próprio desenvolvimento dependerá das tarefas subseqüentes que lhes forem propostas. Externamente, poderá parecer que a criança já domina o conceito, uma vez que tem a sua definição. Mas a generalização dessa definição para ela é distinta (e geralmente mais simples) que a generalização contida, de fato, no conceito.

Deste modo, a colaboração do adulto no processo de aprendizagem da criança visa não a lhe inculcar um conceito em sua forma já maximamente elaborada, mas ao contrário, a auxiliar a criança nos seus processos de generalização das generalizações. Ao definir um conceito, ou ao realizar sínteses com os alunos (ou mesmo fornecer sínteses), o educador está fornecendo materiais para os estudantes trabalharem em seus processos de formação conceitual e não o conceito em sua forma já acabada. E se é um material para o trabalho, o trabalho mesmo que a criança deverá realizar com esse material deve ser pensado pelo educador; planejado por ele. A definição ou transmissão do significado de um conceito, portanto, entra no percurso do trabalho escolar como um dos momentos de ensino e aprendizagem e não como o único ou mesmo o mais importante.

A definição do conceito, como dissemos, serve como um instrumento para que a criança possa realizar a ação mais importante no processo de formação conceitual: as ações de análise e síntese da realidade ou do objeto a ser conhecido. A mediação dos significados conceituais no processo de análise e síntese de um objeto é o que irá permitir à criança operar com os conceitos relacionados ao objeto (estabelecendo a generalização das generalizações) e 
não só operar com o objeto em si mesmo. Em outras palavras, é o ensino organizado a partir dos significados conceituais que permitem à criança relacionar-se em primeiro plano com os conceitos e, em segundo plano, com os objetos a que esses conceitos se referem.

Relacionar-se ou ter como objeto de sua consciência e ação ou a realidade em si mesma ou os conceitos sobre essa realidade, é um aspecto importante no processo de formação conceitual, especialmente no trabalho escolar. Relações distintas com o objeto resultam em tipos distintos de conceitos: os conceitos empíricos ou espontâneos, por um lado e os conceitos científicos ou teóricos por outro (VIGOTSKI , 2009; DAVIDOV, 1988).

A formação dos conceitos teóricos implica em uma nova formação no tipo de relação do sujeito com o mundo. Implica na formação de uma outra atividade, no caso a atividade teórica. Isto porque:

[...] essa formação de conceitos requer atos de pensamento inteiramente diversos, vinculados ao livre movimento no sistema de conceitos, à generalização de generalizações antes constituídas, a uma operação consciente e mais arbitrária com conceitos anteriores. A pesquisa confirma também essas expectativas do pensamento teórico (VIGOTSKI, 2009, p. 269).

Imaginemos o seguinte exemplo. Uma criança reconhece a manifestação de uma cena engraçada numa apresentação de circo. Ela domina esse objeto, essa realidade, reconhece facilmente quando a cena é ou não engraçada e possui um determinado conceito sobre esse objeto (exemplo: cena engraçada é aquela que nos faz rir). Pois bem, neste caso, ainda que a criança tenha um conceito sobre esse objeto em questão e tenha consciência do próprio objeto representado nesse conceito, ela não possui ainda uma consciência do próprio conceito, isto é, do ato de pensamento pelo qual concebe este objeto. Deste modo, para essa criança, a consciência do objeto se dá em proporções muito maiores que a consciência do conceito. Por esta razão, estamos diante de uma relação com a realidade notadamente empírica.

Pensemos agora em uma segunda criança, que também reconhece uma manifestação engraçada em uma cena circense, isto é, que também domine o objeto. Ao relacionar-se com o objeto em questão, porém, notamos que esta criança busca analisar os elementos que estão sendo trabalhados pelo personagem circense para criar uma cena engraçada. Neste caso, o conceito que essa segunda criança traz sobre cena engraçada é distinto do conceito trazido pela primeira criança. Para a segunda, estão em jogo outros conceitos mediadores para a sua relação com a cena engraçada: os elementos que nos permitem criar as cenas, (ângulo de visão, coreografia, narração, movimentos...) e as formas de utilizar esses elementos de modo a 
cometer erros intencionais para a cena ficar engraçada. Assim, ainda que essa criança domine o objeto em si mesmo e tenha consciência do próprio objeto, no momento em que avalia a cena (ou a sua relação com a cena) revela que o objeto de sua consciência deixa de ser a cena em si mesma e passa a ser os conceitos relacionados à criação da cena. O objeto de sua consciência passa a ser os próprios conceitos. Para a segunda criança de nosso exemplo, portanto, a consciência do conceito se dá em proporções muito maiores que a consciência do objeto, ainda que esta última não deixe de existir. Por esta razão, estamos diante de uma relação com a realidade notadamente teórica.

Vigotski (2009) sintetiza essas relações e o próprio processo de formação de um tipo de conceito e de outro da seguinte forma: enquanto a formação dos conceitos espontâneos percorre um caminho que podemos dizer que vai “de baixo para cima” (do objeto para o conceito), a formação dos conceitos teóricos percorre o caminho inverso "de cima para baixo" (dos conceitos para o objeto).

Os conceitos científicos, assim, começam a se desenvolver a partir do trabalho com o próprio conceito e por ações que pressupõem a utilização desse conceito de forma não espontânea. A formação dos conceitos científicos começa por uma relação mediada do sujeito com o objeto: mediação essa dada desde o início por conceitos. Daí a afirmação de Vigotski (2009, p.345) de que “os conceitos científicos começam sua vida pelo nível que o conceito espontâneo da criança ainda não atingiu em seu desenvolvimento”. E daí de nossa afirmação anteriormente elaborada da necessidade de utilizarmos e, muitas vezes partirmos, dos significados dos conceitos - das sínteses conceituais - na organização do ensino escolar.

Em nossas vidas cotidianas, o processo de formação de conceitos começa, invariavelmente, pelo domínio do objeto ou realidade que queremos nos apropriar. Nas atividades não cotidianas, como a atividade de estudo, por exemplo, o processo de formação de um conceito não começa pelo domínio do objeto, mas pelo domínio e trabalho com os conceitos relacionados a este objeto. A criança relaciona-se com o objeto mediada pelos conceitos. Isto significa que os conceitos empíricos que a criança traz de suas experiência cotidianas e que foram formados "de baixo para cima” não entram no processo de formação dos conceitos teóricos? Ao afirmarmos que o domínio dos conceitos teóricos não passa pelo domínio primário do objeto estamos afirmando que os conceitos empíricos não fazem parte deste processo? Absolutamente não.

A formação dos conceitos científicos só pode se dar a partir ou tendo por base os conceitos espontâneos já formados. Os conceitos espontâneos já formados servirão como objeto de ação das crianças para a relação que estabelecerão com a realidade a ser conhecida. 
A criança que conhecia uma cena engraçada trazia uma porção de conhecimentos empíricos sobre a cena engraçada e, mais amplamente, sobre a criação de cenas em geral. Contudo, tais conceitos não eram conscientes para a própria criança e só o puderam o ser quando ela passou a participar de uma atividade que exigisse a consciência destes conceitos e a ação com eles e não mais com o objeto em si mesmo.

Verifica-se nesse fato a confirmação direta de que os conceitos não surgem simplesmente como resultado de uma elaboração lógica desses ou daqueles elementos da experiência, que a criança não atina sobre seus conceitos, e que estes lhe surgem de modo bem diferente e só mais tarde ela toma consciência deles e lhes dá configuração lógica (VIGOTSKI, 2009, p.230).

O processo de tomada de consciência dos conceitos antigos (já elaborados pelas crianças em suas experiências cotidianas), bem como o processo de elaboração de novos conceitos, ocorre a partir de uma atividade especialmente organizada para esse fim. A conscientização dos conceitos se dá a partir da inserção do sujeito em uma atividade em que ele deva agir em primeiro plano com eles e não mais com os objetos. Neste processo, são colocados em jogo todos os conceitos já formados pelo sujeito.

A tomada de consciência de algo, portanto, pressupõe a existência prévia desse algo, ainda não conscientizado. Para conscientizar-me de um movimento, por exemplo, preciso ter um mínimo de experiência ou vivência sobre este movimento, ou sobre os movimentos em geral. Neste último caso, posso me deparar com um movimento nunca antes visto e, mesmo sem fazê-lo, experimentá-lo, conseguir me conscientizar sobre o mesmo, sobre as partes do corpo envolvidas e as relações entre elas. Posso, assim, criar uma imagem ou "modelo" deste movimento em minha cabeça. Como diz Vigotski (2009, p.198) “[...] a criança começa antes a aplicar na prática e a operar com conceitos que a assimilá-los. O conceito 'em si' e 'para os outros' se desenvolve na criança antes que se desenvolva o conceito 'para si'”,

Assim, de algum modo, a criança precisa ter um conceito (um significado) e precisa agir com ele de forma mais ou menos intencional. Ela ainda não tem consciência do próprio conceito, mas age com ele de modo “correto”. Em nosso experimento didático, que será analisado no capítulo seis, podemos verificar crianças que utilizavam os elementos de criação da cena de modo bastante preciso, mas muitas vezes ainda não tinham plena consciência dos mesmos.

O conceito, portanto, deve - em primeiro lugar e antes de passar para o plano verdadeiramente interno do psiquismo - orientar a criança em suas atividades; os conceitos teóricos devem lhes permitir novas possibilidades de ações e, inclusive, de atividades. Mas 
isso não tem a ver com qualquer tipo de relação pragmática da função do conceito. O conceito não orienta novas ações das crianças para que elas resolvam problemas de ordem prática, mas fundamentalmente para que adquiram um novo modo de ação na realidade; para que formem uma atividade teórica com o mundo, nas diversas esferas da vida (como a arte, por exemplo). O conceito implica em mudanças na forma de enxergar ou compreender o mundo e, assim, nas formas de agir nele.

A passagem para um novo tipo de percepção interior significa a passagem para um tipo superior de atividade psíquica interior. Porque perceber as coisas de modo diferente significa ao mesmo tempo ganhar outras possibilidades de agir em relação a elas. Como em um tabuleiro de xadrez: vejo diferente, jogo diferente (VIGOTSKI, 2009, p.289).

A questão maior dessa formação conceitual para o processo de desenvolvimento dos sujeitos, reside, portanto, na possibilidade da criança envolver-se em um outro tipo de atividade em sua vida: a atividade teórica, o que por sua vez lhe abre novas possibilidades de perceber e agir no mundo. Em nosso caso, estudamos e procuramos formar esse tipo de atividade em uma esfera específica da vida humana (a esfera artística). Durante e após a análise dos dados de nosso experimento didático, procuraremos debater a especificidade e a generalidade do pensamento estético-artístico (e da atividade estético-artística) como parte do pensamento teórico e da atividade teórica.

\subsection{A formação da atividade criadora e da imaginação.}

A atividade criadora está, sem dúvida, presente no campo da Arte. Mas não só nela e nem se quer especialmente nela. A imaginação ou a fantasia, como uma manifestação psicológica da atividade criadora do homem, ou da sua capacidade de combinar os elementos da realidade que vivencia de um outro modo, “[...] se manifesta decididamente em todos os aspectos da vida cultural fazendo possível a criação artística, científica e técnica” (VIGOTSKY, 2004, p.7).

Combinar os elementos da realidade, criando com eles uma outra realidade, não é, portanto, característica específica do campo artístico, mas sim de todas as atividades humanas. A história do homem, ou mais precisamente sua relação fundamental com o mundo é a história da criação do mundo humano a partir do mundo natural que o homem tem disponível e no qual adquire as suas experiências. 
A base da atividade criadora, assim, não está apenas em seu produto, isto é, na elaboração de uma realidade ou objeto excepcional ou absolutamente novo, mas sim na habilidade para organizar os elementos da realidade que já são de domíneo, combinando os velhos e os novos elementos de modo a compô-los de outra forma.

Desta afirmação, devemos considerar duas questões: a) o objeto ou o produto que a atividade criadora objetiva; b) a relação entre o processo de criação e a realidade.

Se por um lado, o objeto ou o produto da atividade criadora é um elemento sumamente importante, na medida em que significa a objetivação da imaginação, o ponto final do ciclo da atividade criadora (que sempre se inicia no plano psíquico, em forma de uma idéia ou fantasia), por outro lado, não devemos tomar o produto, em si mesmo, como forma de analisar a existência ou não de uma atividade criadora.

Como dissemos anteriormente, a história da humanidade é, em grande parte, a história da atividade criadora do homem. A criação dos primeiros instrumentos, a criação da pedra lascada, por exemplo, e a despeito de toda a simplicidade deste objeto, representou uma nova forma de relação do homem com o mundo em que ele passa a materializar suas intenções e idéias e a organizar os elementos disponíveis na realidade de outro modo: estabelecendo novas combinações e correlações. Vigotsky (2004, p.7), citando Ribot, diz: “Todos os objetos da vida cotidiana, sem excluir os mais simples e ordinários são, por assim dizer, a imaginação cristalizada.” E por mais simples que fossem essas novas combinações, elas estavam subordinadas a uma idéia ou intenção do homem.

Nesse sentido não podemos atribuir à atividade criadora apenas àqueles produtos relacionados a uma atividade criadora excepcional. A essência mesma da atividade humana no mundo é a criação. A imaginação é uma função vital e necessária para a atividade do homem no mundo. De acordo com Vigotsky (2004, p.8). “[...] de igual forma, a criação não existe unicamente onde se criam grandes obras históricas, mas também onde quer que o homem imagine, combine, transforme e crie algo novo, por pequeno que seja em comparação com a obra dos gênios”.

Uma segunda questão necessária de ser analisada na atividade criadora é a relação da imaginação com a realidade. Seria mais rica aquela imaginação que consegue se afastar mais da realidade na qual está inserida? Qual a relação entre a realidade que o sujeito vive e adquire experiência e a sua atividade criadora?

Partimos da afirmação de que a imaginação está sempre estruturada pelos materiais que a realidade lhe fornece: “[...] a atividade criadora da imaginação depende diretamente da riqueza e diversidade da experiência anterior do homem [...]” (VIGOTSKY, 2004, p 12). 
A criação de uma nova realidade (material ou não material) sempre se estrutura a partir dos elementos tomados da realidade da qual o sujeito faz parte. Para criar um novo objeto, uma nova realidade, o homem parte das experiências já adquiridas na realidade em que vive. Mesmo aquelas criações mais fantásticas, aparentemente distantes de quaisquer realidades efetivamente existentes, são o resultado de novas combinações de elementos extraídos de realidades já existentes e vivenciadas, direta ou indiretamente, por parte do sujeito criador. A criação de um monstro em uma história, por exemplo, é o resultado mais ou menos consciente por parte do autor de sua atividade criadora, que modificou ou recombinou elementos da realidade efetivamente existentes em nossas vidas cotidianas.

Assim, por um lado, a nossa realidade imediata serve de base para a nossa atividade criadora, fornecendo-nos os materiais ou elementos que iremos recombinar. E neste sentido “quanto mais rica seja a experiência do homem, maior será o material com que contará a sua imaginação” (VIGOTSKY, 2004 p.12).

Por outro lado, não só (e muitas vezes, não fundamentalmente) a realidade imediata é a que serve de base para a atividade criadora do homem. A realidade criada por outros homens, isto é, a realidade vivida por outros homens e sintetizada em determinados produtos de suas atividades, pode ser o ponto de partida de nossa atividade criadora. Nas palavras de Vigotsky (2004, p.12): “se seguimos a história das grandes invenções, quase sempre se pode estabelecer que foram o resultado de uma grande experiência acumulada anteriormente”.

A partir desse entendimento da imaginação e da atividade criadora podemos compreender a imaginação como um meio de ampliação da experiência individual de cada sujeito. A maioria dos homens nunca esteve na lua, mas é capaz de imaginar as condições lá existentes não só pelas imagens hoje disponíveis, mas também pelas descrições de outros homens que lá estiveram ou que se debruçaram no estudo deste astro.

Vigotski (2001), conforme exposto no capítulo dois, atribuiu à arte a função de uma “técnica social dos sentimentos”, ressaltando, aí, o caráter coletivo da atividade criadora. Uma vez que a criação em geral e a arte em particular servem como uma forma de ampliar a experiência individual de cada sujeito, ela possui uma dimensão fundamental no processo de desenvolvimento de cada um de nós. Os processos de imaginação que se dão hoje, em nosso mundo contemporâneo, por mais “criativos” e pessoais que sejam, se apóiam sempre na experiência de outros sujeitos.

Todo inventor, inclusive o gênio, é sempre um fruto de seu tempo e de seu meio, sua criação parte das necessidades que estão criadas antes dele e se apóia nas possibilidades que ademais existem fora dele; por isso observamos 
uma ordem estrita no desenvolvimento histórico da técnica e da ciência. Nenhuma invenção ou descobrimento científico aparece antes que se criem as condições materiais e psicológicas necessárias para seu surgimento; a criação é um processo articulado, historicamente, onde toda forma seguinte está determinada pelas precedentes (VIGOTSKY, 2004, pp.25/26).

Uma das formas de experiência acumulada pela humanidade e que é fundamental para a atividade criadora, é a linguagem. A linguagem e os significados das palavras (os conceitos), enquanto forma do homem se aproximar e refletir a realidade que o cerca, é o resultado de dois tipos de atividade do homem no mundo: a atividade empírica e a atividade teórica.

De acordo com Luria (2005), os sujeitos não escolarizados ou que não puderam formar e desenvolver a capacidade de utilização das operações lógicas e abstratas, apresentam um domínio mais ou menos absoluto da experiência prática sobre sua consciência. E essa relação ou domínio da realidade imediata sobre o sujeito, está presente, também, na sua atividade de imaginação.

A partir dessa análise, Luria distingue dois tipos de imaginação: a imaginação reprodutiva e a imaginação criativa, argumentando que "a imaginação pode estar firmemente ligada à experiência prática ou pode ocorrer dentro de um sistema de pensamento lógicoverbal” (2005, p.181).

Mas acaso essa frase não entra em contradição com o princípio anteriormente defendido por nós de que a imaginação é tanto mais rica conforme for a riqueza da realidade do sujeito, ou conforme for a riqueza de suas experiências nessa realidade?

A atividade criadora criativa representa uma relação tal com a realidade que o sujeito precisa operar com a análise e a síntese dos elementos da realidade em questão. Para criar uma nova realidade, um objeto (seja ele artístico, científico ou prático), o sujeito precisa analisar a realidade, abstraindo os elementos mais essenciais dela e, posteriormente, os sintetizá-los de um outro modo, compondo com eles uma nova realidade.

Toda essa atividade do homem cujo resultado não é a reprodução de impressões ou ações que formaram parte de sua experiência, mas a criação de novas imagens ou ações, pertence também a esta segunda função criadora ou combinadora. O cérebro não só é o órgão que conserva e reproduz nossa experiência anterior, mas também é o órgão que combina, transforma e cria a partir dos elementos dessa experiência anterior as novas idéias e a nova conduta (VIGOTSKY, 2004, p.6). 
A atividade criadora reprodutiva, por outro lado, representa um criar mais de memória, reproduzindo de modo mais ou menos igual uma experiência diretamente vivenciada pelo sujeito. Como diz Vigotsky (2004, p.5) “[...] em todos estes casos reproduzimos só o que existe diante de nós ou o que foi assimilado ou criado com anterioridade, nossa atividade não criou nada de novo, o principal, sua base, é a repetição com maior ou menor exatidão de algo passado”. Este tipo de atividade criadora, contudo, cumpre uma importante função no processo de desenvolvimento do sujeito ao lhe permitir a reprodução da genericidade.

Assim, podemos dizer que a imaginação reprodutora, por um lado, se aproxima mais da realidade que a imaginação criadora. Mas tal afirmação só pode ser considerada ao tomarmos por base a realidade imediata do sujeito ou a sua realidade empírica. Se tomarmos por base a realidade teoricamente elaborada, a realidade percebida em seus múltiplos aspectos ou em sua essência, a imaginação criadora se aproxima mais da realidade do que a imaginação reprodutora. Nesta medida, contribuir para que os sujeitos desenvolvam a sua atividade criadora efetivamente criativa, é uma forma de auxiliar o desenvolvimento de sua relação teórica com o mundo. E essa é uma defesa ética e política.

Analisar os processos da imaginação e da atividade criadora nos leva a pensar sobre a relação do ensino e da aprendizagem para o desenvolvimento desta atividade no homem. Nesta pesquisa, interessa-nos pensar, especificamente, sobre os processos de ensino e aprendizagem que se dão na escola.

A primeira consideração que devemos fazer é sobre a condição de produto e não de premissa da imaginação no processo de desenvolvimento de cada sujeito. Como uma função psíquica superior, a imaginação não é primária, não antecede o próprio processo de desenvolvimento cultural do sujeito, pelo contrário, é já um produto deste desenvolvimento e está organicamente vinculado a ele. "Em cada período do desenvolvimento a imaginação criadora trabalha de maneira singular e própria precisamente de acordo com o grau de desenvolvimento em que esteja a criança” (VIGOTSKY, 2004, p.27).

Nesta medida, como nos contrapormos a idéia de que as crianças apresentam uma imaginação mais rica que a dos adultos? Como analisar o entendimento de que a fantasia seja uma capacidade primária no homem e que, ao invés de ir se desenvolvendo, vai passando por um processo de "atrofiamento"?

Se considerarmos e concordarmos com a tese de que a imaginação é tanto mais rica quanto for a experiência do sujeito em determinada realidade, chegamos à conclusão de que as crianças, por terem - geralmente - uma experiência mais pobre que a do adulto (simplesmente por terem vivido menos e terem passado por menos tipos e qualidades de 
vivências no mundo), apresentam uma imaginação mais pobre que a do adulto, assim como interesses criativos mais simples e elementares.

\begin{abstract}
A imaginação na criança não é mais rica, mas sim mais pobre que a imaginação do adulto; no processo de desenvolvimento da criança se desenvolve também a imaginação, alcançando sua maturidade somente na idade adulta (VIGOTSKY, 2004, p.28).
\end{abstract}

A criança pode imaginar e criar muito menos que os adultos. Entretanto, há uma especificidade na sua relação com a imaginação, que cria a aparência de ser uma imaginação mais rica: a criança confia mais nos produtos da sua imaginação e, ao mesmo tempo, domina menos esses processos e seus produtos (VYGOTSKI, 2004).

Tal qual as demais funções psíquicas superiores que vão se formando na infância, a imaginação começa o seu desenvolvimento como uma função não arbitrária ou consciente por parte da criança. A imaginação, tal qual a memória e a atenção, inicia seu desenvolvimento vinculada fortemente às situações imediatas que a criança vivencia. De certa forma, o primeiro modo de criação das crianças é, necessariamente, uma criação reprodutiva, ou uma criação de memória, fato que lhe permite ir se apropriado da genericidade humana. Só posteriormente, essa função psíquica vai se tornando voluntária e consciente.

Diante dessas questões, devemos considerar que o processo mesmo de educação da atividade criadora dos homens deve ser algo intencionalmente planejado e que pressuponha a transição de uma atividade criadora mais diretamente vinculada à realidade imediata para uma atividade criadora que possa se libertar desse determinismo da realidade, criando novas realidades, sem, contudo, prescindir da experiência e dos elementos da realidade vivenciada.

Deste modo, a escola deve ser o local e o espaço para a criança ampliar a sua experiência, tanto a experiência em geral, quanto às experiências específicas relacionadas a cada um dos tipos de atividade criadora do homem. Esta ampliação de sua experiência visa mobilizá-la para a atividade de criação, considerando que:

Não devemos esquecer que a lei fundamental da criação infantil consiste em que seu valor há de ser visto como resultado no próprio processo e não como um produto da criação, o importante não é o que criam as crianças, o importante é que criem, que exercitem a imaginação criadora e a materializem (VIGOTSKY, 2004, p.62).

Isso não significa, para nós, a negação dos produtos criados e nem sequer a secundarização desses produtos. Vigotski é explícito na necessidade de se materializar a imaginação, isto é, transformá-la em um objeto ou produto. A questão, portanto, reside no 
foco do trabalho educativo (garantir que as crianças criem conscientemente os seus produtos, que componham os elementos da realidade do modo mais voluntário possível) e que o produto mesmo de sua atividade criadora seja analisado apenas em relação com o processo da atividade como um todo. O produto, em si mesmo, desvinculado do processo de criação do sujeito, geralmente não é capaz de nos dizer sobre a atividade de criação deste mesmo sujeito e, portanto, sobre o tipo de pensamento que este sujeito esteja desenvolvendo.

\subsection{A arte e o pensamento teórico: o pensamento estético-artístico.}

Ao falarmos em qualidades estéticas de um objeto, não estamos falando de qualidades que pertencem diretamente a este objeto. Uma estátua de madeira que contenha determinadas qualidades estéticas não as contém na madeira propriamente dita, isto é, a qualidade estética não está previamente na madeira, mas sim na escultura produzida pelo homem neste material. Neste exemplo, ainda que possamos argumentar que a madeira, enquanto um objeto, possua certas qualidades, certas belezas, ainda assim, estamos dizendo de características que o homem atribuiu à madeira e não a características que a madeira possua por si mesma.

Portanto, quaisquer qualidades estéticas a que possamos nos referir são qualidades criadas pelo homem, a partir de seu domínio de diversos elementos naturais dos objetos (cor, peso, proporção, forma, dureza, tempo, espaço etc). Este domínio permitiu ao homem combinar ou organizar tais elementos de uma forma específica, fazendo surgir, precisamente, as formas artísticas.

O momento em que o homem pode desenvolver a sua capacidade de percepção dos elementos e, sobretudo, a sua capacidade de combinação deles de acordo com as suas intenções, foi um passo decisivo para o desenvolvimento humano em geral e para o desenvolvimento da arte em específico. A atividade artística contribuiu para o desenvolvimento da capacidade de abstração e síntese no homem, para a capacidade de separar o essencial e o não essencial da realidade e separar o objeto de sua representação. Reproduziremos um trecho sobre esta relação:

Após um longo processo, que começa desde o momento em que a mente humana, um tanto por acaso estabelece uma primeira associação entre um acidente rochoso e a cabeça de um animal, ou entre a marca da mão e a mão real, depois de passar pela conquista das noções de unidade, semelhança e diferença, bem como por uma elevação da sua capacidade de abstração, de separar no objeto o essencial e o inessencial, o homem pré-histórico chega a traçar figuras que reproduzem animais vivos. O desenho de um bisonte 
expressa o conhecimento que o assustado caçador pré-histórico tem deste animal. Se o pintor de Altamira modela as formas e desenha o contorno com uma grande exatidão, é porque já elevou consideravelmente a sua capacidade de sintetizar, de abstrair e generalizar (VAZQUEZ, 1968, p.78, grifo nosso).

Para que o homem pudesse, então, reproduzir o real deste modo particular (na arte), ele teve de desenvolver as suas capacidades de captar aquelas características que eram essenciais do objeto a ser representado, bem como sintetizá-las de um modo específico: por um lado considerando a relação do objeto representado com o homem e, por outro lado, considerando as particularidades dos materiais com os quais iria trabalhar para reproduzir tal objeto (pintura na parede, escultura na madeira, representação dramática etc.).

Esse processo de abstrações e sínteses que acompanhou o desenvolvimento da arte certamente não foi exclusivo e nem sequer pioneiramente desenvolvido nela. Como já afirmamos, e de acordo com nossa fundamentação teórica, tais capacidades surgiram na atividade prática originária que fundamentou a consciência e a existência do homem: o trabalho. De todo o modo, a arte conduziu o desenvolvimento das capacidades de abstração e síntese de um modo peculiar, tanto por seu conteúdo (o explicitar do humano no mundo de objetos e relações entre os indivíduos) quanto por seu método (as diferentes formas de expressão artística e os materiais e técnicas a eles relacionados).

A despeito de tudo isso, ainda nos resta pensar em que medida estes processos de abstração e síntese, desenvolvidos na arte, se aproximam do pensamento teórico, de um tipo de conhecimento teórico do mundo.

Discutimos, anteriormente, que a arte, partindo de uma realidade concreta, cria uma nova realidade (a realidade artística). Esta criação da obra artística implica na organização do real concreto, de modo que o mesmo possa se elevar para um real pensado, o que no caso da obra artística significa um real que exprima a essência humana contida naquele real concreto.

Para a elaboração desse processo, faz-se imprescindível à presença do pensamento teórico, posto que a síntese alcançada (o real elaborado ou real pensado) deve ser uma síntese que contemple a unidade fundamental ou a relação essencial entre os elementos do real concreto e não simplesmente uma representação das diversas características percebidas naquele real. “A criação de uma imagem artística pressupõem a presença, no homem, da imaginação altamente desenvolvida como capacidade graças a qual ele pode ver o todo antes das partes e fazê-lo corretamente” (DAVIDOV, 1988, p.220).

Desta forma, na criação artística, tal qual na criação científica, o trabalho humano deve percorrer o caminho do geral para o particular, revelando as generalizações substanciais e, 
assim, fazendo com que o seu pensamento de artista ou de público se eleve do concreto real ou caótico, para o concreto pensado ou artístico, mediado pelas abstrações essenciais.

A partir desse processo, a afirmação de que a obra artística não seja uma simples cópia do real pode ser compreendida. Já no processo de análise da realidade (e elaboração das suas características ou abstrações essenciais), o artista deve estabelecer um rompimento das ligações “naturais” existentes nos objetos ou fenômeno que irá representar (seja qual for a sua forma de representação) a fim de poder explicitar, na sua síntese, o conteúdo fundamental da arte: o humano em sua particularidade.

Para criar um personagem literário, o escritor precisa - a partir de sua vivência real, com diversos tipos de pessoas com as quais se relacionou - destacar determinadas características presentes nelas que julga pertinente para o seu personagem. Contudo, essas abstrações das características dão-se a partir de uma unidade buscada pelo autor: criar um tipo específico de personagem: vilão, herói, guerreiro etc. Com base nessa idéia geral de tipos de comportamentos humanos o autor destaca as características de pessoas da realidade concreta. E é a partir de uma síntese peculiar entre aquelas características universais (guerreiro, vilão...) e as características singulares (das pessoas que teve contato) que o autor irá criar o seu personagem, que sintetizará o universal e o singular em um personagem concreto, particular. Nesta medida, podemos compreender a frase de Marx ao tratar sobre o realismo nas obras de arte: “o realismo, para mim, implica, para além da verdade do pormenor, a produção verdadeira de personagens típicos em circunstâncias típicas” (MARX; ENGELS, 1980, p.70).

Artistas e público, portanto, devem se relacionar com a obra de arte como uma síntese entre o universal e o singular; como uma síntese concretizada de um objeto particular (na obra) que fará a mediação para o trânsito de nosso pensamento tanto para a dimensão do universal, presente naquela obra, quanto para a dimensão do singular, do sentido que terá para nós. Nesta medida, também, a arte forma um tipo específico de pensamento teórico: o pensamento estético-artístico.

Ressaltamos, aqui, a necessidade de formação do pensamento estético-artístico tanto por quem faz a obra de arte, quanto por quem dela se apropria. Artistas e público devem desenvolver esse tipo específico de pensamento teórico. Na verdade, a formação de cada sujeito singular, o seu processo de humanização a partir da arte, deve se dar tanto na dimensão do artista quanto na dimensão do público. A percepção da arte, da obra artística, exige igualmente de nós uma dimensão criadora. 
Eis por que a percepção da arte também exige criação, porque para essa percepção não basta simplesmente vivenciar com sinceridade o sentimento que dominou o autor, não basta entender da estrutura da própria obra: é necessário ainda superar criativamente o seu próprio sentimento, encontrar a sua catarse, e só então o efeito da arte se manifestará em sua plenitude (VIGOTSKI, 2001, p.314).

A base da criação está, justamente, na capacidade para organizarmos os diversos elementos que conhecemos da realidade; capacidade para combinar o velho com o novo. Trata-se, pois de uma capacidade essencialmente humana e que pode e deve ser formada em cada sujeito singular.

E onde deveria se dar essa formação? Como manifestação específica do pensamento teórico, a capacidade de criação em geral e o pensamento estético-artístico em particular, devem ter suas bases formadas na escola, em atividade de estudo, intencionalmente elaboradas pelo professor. Em nossa sociedade, e como já defendemos neste trabalho, entendemos que é a escola o local privilegiado para se trabalhar a formação do pensamento teórico nos sujeitos.

Davidov (1988), estudando esse tipo de formação na escola, identifica a existência de determinadas disciplinas escolares pertencentes ao que ele chamou de "ciclo estético" (literatura, música e as artes plásticas). Consideramos que pelos objetos de que trata, a educação física também possa ser inserida neste “ciclo estético” de disciplinas escolares. Tais disciplinas estão voltadas, especificamente, para a formação e desenvolvimento da consciência estética dos estudantes. Para desenvolver essa consciência estética, o ensino deve formar nos alunos a atitude para separar na realidade (ou no material didático) não só os objetos mesmos e suas partes, mas, sobretudo, as relações entre eles. Deve contribuir, para que estabeleçam uma relação de análise e síntese teóricas da realidade em questão.

O conteúdo fundamental do ensino das disciplinas do ciclo estético é a assimilação pelas crianças do procedimento geral de percepção adequada e criação da forma artística. Este procedimento geral se chama composição. A composição é a criação, a união, o estabelecimento das relações, o ordenamento e a unificação das partes ou elementos de algo que deve converter-se em um todo (neste sentido, a composição está ligada à atividade artística, científica e técnica). Em relação à arte, a composição é o procedimento geral da objetivação (para o artista) ou da desobjetivação integral (para o espectador) da idéia artística, o procedimento geral de passagem da idéia a sua realização ou, ao contrário, da percepção da forma na qual está realizada a idéia e o conteúdo do quadro (DAVIDOV, 1988 p.22, grifo nosso). 
Evidencia-se, assim, que a formação da consciência estética, ou para nós do pensamento estético-artístico, deve corresponder ao fato de que a obra de arte não é constituída por seus elementos ou conjunto de elementos, mas justamente pela relação entre eles, pela relação dos diversos elementos na obra. Entretanto, essa relação com o todo da obra artística, muitas vezes, não pode ser alcançada espontaneamente, em nossas vidas cotidianas.

Afirmarmos a dimensão humanizadora da arte e da formação do pensamento estéticoartístico, não significa negarmos a possibilidade (e forte tendência em nossa atual sociedade) dessa humanização se dar de modo desumanizado. A arte, tal qual as demais atividades humanas, está inserida em uma sociedade alienada e, portanto, contribui para a reprodução dessa alienação. Entretanto, ao reproduzir a alienação da sociedade, reproduz, também, as suas contradições, o que lhe permite, dentro de certos limites, contribuir para a formação humana de modo verdadeiramente humanizado. Nesse sentido, a organização do ensino para a formação do pensamento estético-artístico ganha importância. 


\section{ELEMENTOS PARA A ORGANIZAÇÃO DO ENSINO E A FORMAÇÃO DO PENSAMENTO ESTÉTICO-ARTÍSTICO}

Podemos dizer que o que caracteriza fundamentalmente o pensamento estéticoartístico, o que permite aproximá-lo do pensamento teórico e especificá-lo como uma dimensão desse tipo de pensamento, é a relação de análise e síntese que estabelece com o real. Desenvolver o pensamento estético-artístico implica em desenvolver a capacidade de abstrair os elementos essenciais de um fenômeno (análise) e os sintetizar em um novo fenômeno ou no objeto artístico (síntese).

Como vimos, a arte cria uma nova realidade baseando-se na realidade concreta existente. A realidade concreta (que em um primeiro momento é caótica, é a realidade em si mesma) não pode ser prontamente transposta para o objeto artístico, tal como consideramos ao longo deste trabalho. A arte não é nem a aglomeração dos diversos elementos perceptíveis da realidade, nem a materialização da percepção em si mesma, mas, justamente, a criação de um outro real, de um real elaborado ou pensado a partir de todos esses elementos. Como realidade pensada é um produto do pensamento, que procura expressar uma determinada relação fundamental entre esses diversos elementos da realidade, relação essa que explicite a unidade ou a essência da realidade em questão e que irá conjugar o universal e o singular em si.

Por realizar esse movimento do concreto real ou caótico para o concreto pensado é que a arte se aproxima do pensamento teórico: a arte expressa o movimento de ascensão do concreto ao concreto pensado mediado pelas abstrações - processo de análise e síntese do real, buscando as suas determinações fundamentais - (DAVYDOV, 1982; KOPNIN, 1978).

Contudo, a atividade artística percorre esse caminho de um modo específico. A realidade que ela cria, isto é, o objeto artístico, não se equivale ao universal (podemos talvez dizer: ao significado historicamente elaborado sobre essa realidade), nem tampouco ao singular (ao sentido pessoal que a realidade tenha para o sujeito que a elaborou ou que dela irá fruir). A obra artística sintetiza o universal e o singular através do particular, que segue o seu papel de mediação de nosso pensamento entre o universal e o singular. Tanto o artista quanto o público relacionam-se com a obra de arte como um elemento da ordem do particular e, através dela, podem alcançar tanto o singular quanto o universal contidos nesta obra. Aqui residiria a especificidade do pensamento estético-artístico no pensamento teórico. O que está em primeiro plano numa obra de arte não é nem o seu aspecto universal (o significado) nem o 
seu aspecto singular (o sentido), mas a dimensão do particular (que contem aqueles dois aspectos).

Conseguir, então, expressar (no caso do artista) e captar (no caso do público) a realidade como uma totalidade são condutas que expressam o pensamento estético-artístico nos sujeitos. Isso quer dizer que a formação artística - pensamento e condutas - deve se dar em todos os sujeitos e em suas duas dimensões: como artista e como público.

Artista e público, ou aquele que produz a obra e aquele que a capta, para poderem se relacionar de modo peculiar com o singular e o universal devem ser capazes de organizar os elementos que compõem a obra de arte, de modo que os mesmos formem uma unidade que capte a realidade em sua essência humana. Ao produzir ou ao apreciar uma obra de arte o sujeito deve analisá-la a partir desse todo, a partir dessa unidade fundamental e não de uma simples justaposição de seus diversos componentes.

Se estivermos, por exemplo, criando ou apreciando um espetáculo de circo, devemos ter por conta, para a sua produção ou apreciação, a estrutura da apresentação. Assim, os diversos elementos que tomam parte de um espetáculo de circo: os movimentos executados pelos personagens (quais são eles e como são executados), a utilização do espaço e do tempo (seqüência das ações no palco); as intenções apresentadas em cada cena (comicidade, suspense, beleza...); o vestuário e o cenário etc, não podem ser tomados em si mesmos e nem como um conjunto de somatórias. Eles devem ser tomados dentro da estrutura geral de apresentação $^{19}$ : a composição de um início, um meio e um fim para cada cena e para o espetáculo como um todo, a qual está subordinada a uma determinada idéia ou intencionalidade (a um objetivo).

O que fazemos, então, é combinar os diversos elementos a partir ou de acordo com uma determinada intencionalidade, separando, na realidade concreta, aquilo que é essencial do não essencial e elegendo, assim, uma unidade ou célula para a composição.

Os modos da relação estética para com a realidade estão fixados historicamente nas obras artísticas. Para colocar em evidência e assimilar esses modelos as crianças devem dominar a 'linguagem' da arte, quer dizer, os procedimentos que o artista utiliza para expressar a sua relação com o mundo. Os meios de expressão dos diferentes tipos de arte (poesia, música, pintura etc.) tem tanto propriedades particulares como gerais.

Muitas causas geram a especificidade da forma artística dos diferentes tipos de arte. Entre eles pode-se citar: as propriedades peculiares do material:

\footnotetext{
${ }^{19}$ Estamos considerando que a estrutura geral da apresentação (inicio/meio/fim), criada a partir da composição dos elementos que fazem parte de uma manifestação artística em específico, é a unidade de análise e produção de um espetáculo: seja de dança, circo, ou teatro. Cada um desses fenômenos artísticos e os diversos elementos que fazem parte deles deverão ser compostos a partir e por meio daquela unidade fundamental de análise.
} 
(cor, volume, som) que utiliza o pintor, o escultor, o músico e, em conseqüência, a diferente modalidade da percepção de quem vê ou escuta as obras (DAVIDOV, 1988, p.219).

Resta, então, esboçarmos as bases do ensino para a formação do pensamento estéticoartístico, bem como as formas de conduta a ele atrelada. Teremos como objeto para essa análise as atividades artísticas relacionadas à educação física ou à cultura corporal. Focaremos nossa análise, neste momento, na atividade circense, enquanto atividade da cultura corporal que carrega em si - como significado essencial - uma dimensão estética e artística da atividade humana.

O circo (e podemos dizer, também a dança, como outra manifestação da cultura corporal) contém, em si, determinados modos de relação estética do homem com a realidade, modos esses que possuem tanto uma dimensão genérica, quanto uma dimensão específica. A dimensão específica seria encontrada, sobretudo, na forma ou nas peculiaridades do material no qual a obra se produz. Na dança e no circo esse material é prioritariamente o próprio corpo e as possibilidades de ações com ele. Esse material específico cria uma relação também específica do artista com a estética, cria uma forma de sensibilidade própria ao objeto, assim como cria, para o público, uma forma também própria de percepção desta obra.

Pois bem, para que esse modo de relação estética presente na dança e no circo possa ser apropriado pelos sujeitos em atividade de estudo ${ }^{20}$ (quer tenhamos como foco a formação do artista ou a formação do público), os educandos deverão se apropriar não apenas da obra em si mesma, mas, especialmente, da atividade que produziu tal obra. Deverão, assim, “reproduzir os traços essenciais dessas atividades” (LEONTIEV, 1978).

Reproduzir os traços essenciais de uma atividade artística implica na reprodução dos procedimentos que o artista utiliza para expressar a relação estética do homem com o mundo. O procedimento não pode ser entendido apenas como "as técnicas” (no caso do circo, as diversas técnicas corporais), mas sim e fundamentalmente como o modo de ação para criar uma nova realidade, uma realidade artística. Novamente, utilizando o circo como exemplo, teríamos que esse modo de ação refere-se à composição dos diversos elementos presentes no circo, tendo como unidade a estrutura geral da apresentação (a composição de uma cena), que

\footnotetext{
${ }^{20}$ Utilizaremos o termo atividade de estudo para nos referirmos a uma atividade intencionalmente elaborada pelo professor e que visa criar nos educandos a necessidade de se apropriarem teoricamente do real, no caso, a necessidade de se apropriarem do pensamento estético-artístico. A atividade de estudo na teoria históricocultural, representa a atividade principal das crianças no início da escolarização (o que corresponderia ao nosso ensino fundamental I). Este conceito está desenvolvido nas obras de Davidov (1987; 1988).
} 
por sua vez está subordinada à intencionalidade da atividade em questão (o circo tem que ser engraçado; bonito; surpreendente; bizarro ${ }^{21}$ ).

Para que os educandos reproduzam a atividade artística de modo a terem como objeto de suas ações esses traços essenciais da obra de arte ou os procedimentos utilizados pelo artista para expressar a relação estética, é preciso que ele tome parte de uma atividade especialmente organizada para esse fim. É preciso que tome parte de uma atividade em que ele se portará (seja como artista, seja como público) mediado pelos traços essenciais dessa atividade artística. Essa atividade especial é, justamente, a atividade de estudo.

Assim, para formar o pensamento estético-artístico, o educando deverá se apropriar daquela atividade humana que produziu a obra artística em questão (a atividade do artista circense, por exemplo), de modo que possa reproduzir aquilo que há de essencial nessa atividade: os procedimentos ou os modos de ação que o artista utiliza e que lhe permite compor, com os elementos que dispõe, um objeto que expresse uma determinada relação estética do homem com o mundo.

Com este exemplo podemos nos deter na análise de uma questão que nos parece central no ensino das atividades artísticas e na formação do pensamento estético-artístico: reproduzir a atividade do artista não é o mesmo que reproduzir algumas de suas ações ou mesmo um conjunto delas. Se pretendo reproduzir a atividade circense, enquanto uma atividade verdadeiramente artística, e passo a reproduzir os movimentos que os personagens executam e a vestir a roupa que os personagens utilizam, eu me aproximo não tanto da atividade artística circense, mas muito mais de "algumas ações existentes na atividade de circo”. O que falta para que essa atividade seja reproduzida enquanto atividade e não apenas como ações? Falta subordinar as minhas ações ao modo geral de ação ou ao procedimento do artista circense: a sua intencionalidade (o significado da apresentação) e a composição dos diversos elementos que compõem o circo (movimentos, coreografia, ângulo de visão, vestuários etc.) dentro da estrutura geral de uma apresentação (início/ meio/ fim). Reproduzindo esse movimento de criação de um espetáculo, reproduzindo esse modo geral de ação, consciente do meu movimento de criação de um objeto artístico, poderei reproduzir e me apropriar do circo como uma atividade artística e, deste modo, permitir a formação do meu pensamento estético-artístico.

\footnotetext{
${ }^{21}$ Essas diversas intencionalidades têm a ver com o papel que o circo cumpria e cumpre em uma determinada sociedade. Entender o circo como o local de apresentar o bizarro, por exemplo, tem a ver com um modo de compreendê-lo em que o central seja apresentar, para o público, aquilo que é exótico (a mulher barbada, os anões, o homem gigante etc).
} 
Em suma, este modo geral de ação, esta unidade da atividade circense, deve estar presente nas atividades de aprendizagem como um eixo das ações dos educandos, quer se trate da análise de uma apresentação de circo (formação enquanto público), quer se trate da construção de uma apresentação (formação enquanto artista).

Retomaremos aqui, de forma ainda provisória e como uma primeira aproximação às perguntas que movem esta pesquisa, algumas questões propostas no início deste trabalho: quais os processos que a cultura, mediada pelo ensino da educação física direciona ou desencadeia no processo de desenvolvimento do homem? Como o ensino da educação física pode contribuir no processo de formação do pensamento estético-artístico?

Ambas as questões remetem-nos a olhar para o objeto específico de que trata a educação física, seu objeto de ensino e de aprendizagem. Para nós, e como tentamos indicar em alguns momentos deste trabalho, o objeto da educação física não é aquilo que de mais imediato aparece para nós: o movimento, ou o se movimentar. Este nos parece ser uma forma de se manifestar o seu verdadeiro objeto, isto é, a ação motora representa o material no qual o objeto da educação física se objetiva. O objeto da educação física é, para nós, a atividade humana, com toda a sua estrutura de motivos, necessidades, ações e operações, que se vinculam direta ou historicamente à cultura corporal. Tais atividades objetivam, em si, determinadas formas de conduta e determinados tipos de pensamento que deverão ser apropriados pelos educandos, tais quais: o pensamento científico, o pensamento filosófico e o pensamento estético-artístico (foco deste trabalho).

Dizer isso significa atribuir à educação física uma atuação maior do que ela de fato pode ter? Ou ainda, significaria repetir nessa disciplina o que outras áreas já fazem com propriedade (posto que a filosofia já garantiria a formação do pensamento filosófico, as ciências do pensamento científico e a arte do pensamento artístico)? Pensamos que não. Ao considerarmos que a atividade de aprendizagem da educação física deva se dar pela apropriação das atividades da cultura corporal e, neste processo, na apropriação dos pensamentos científico, filosófico e estético-artístico a elas vinculadas estamos afirmando simultaneamente - o caráter genérico da educação física como uma disciplina escolar (que deve contribuir para a formação do pensamento teórico dos educandos) e o seu caráter específico, já que esses tipos de pensamento só se formarão, na educação física, mediado pelo "material” específico dessa disciplina: as atividades da cultura corporal (o circo, a dança, os jogos, as lutas etc) que mais do que sintetizarem diversos tipos de "movimentos" ou ações motoras, sintetizam um modo do homem se relacionar com o mundo, com os outros e consigo mesmo. 
A formação do pensamento teórico em geral, e a formação de um dos seus tipos específicos (o pensamento estético-artístico, por exemplo) ocorre sempre mediado pela existência de um objeto concreto, objeto este que contenha os traços de tal pensamento. Ampliar a apropriação dos objetos e das atividades humanas relacionadas ao pensamento teórico nos parece ser uma medida importante no processo de ampliação das necessidades e das relações que o sujeito estabelece com o mundo (formas de estar e agir no mundo). Nesta medida, trata-se de uma ampliação da riqueza do homem singular no mundo universal, mediado pelos objetos particulares. E nesta concepção, tornar cada sujeito mais rico em necessidades humanas é uma das finalidades da educação escolar.

\subsection{A categoria atividade na formação do sujeito: estrutura}

É bem conhecida a tese marxiana de que o homem seja fruto das múltiplas relações materiais em que vive. As circunstâncias objetivas, as relações sociais, são as forças determinantes na formação de cada sujeito. É igualmente bem conhecida e difundida uma crítica a essa mesma tese: a concepção marxista de formação humana é reducionista, tanto por reduzir as “circunstâncias objetivas” às relações econômicas, quanto por desconsiderar a dimensão do sujeito (ou indivíduo) nessa relação.

De fato, a concepção materialista histórico-dialética compreende que as condições materiais que produzem e reproduzem a vida de cada sujeito são as condições centrais de sua formação; mas isto não é o mesmo que dizer que é a economia que determina a formação dos sujeitos. Engels, em uma carta a Joseph Bloch, em 1980, analisa essa distorção da teoria que ele e Marx elaboraram:

De acordo com a concepção materialista da história, a produção e a reprodução da vida real constituem, em última instância, o fator determinante na história. Nem Marx nem eu jamais afirmamos mais do que isso. Se alguém torce isso para afirmar que o fator econômico é o único fator determinante, esse alguém transforma a nossa afirmação em uma frase absurda, abstrata e sem significado. A situação econômica é a base, mas todos os fatores da superestrutura - as formas políticas da luta de classes e seus resultados, as constituições adotadas pelas classes vitoriosas depois de vencerem na batalha, as formas legais, e ainda mais do que isso os reflexos dessas lutas reais na cabeça dos homens que são envolvidos nelas: as teorias políticas e filosóficas, as concepções religiosas, tanto em seus aspectos terrenos como em seus aspectos mais desenvolvidos e em suas formas dogmáticas - todos os fatores da superestrutura, repito, também influenciam o curso das lutas históricas e, em muitos casos, desempenham o papel 
dominante na determinação da forma dessas lutas (ENGELS, apud FISCHER, 1976, p. 47, grifo do autor).

Deste modo, no interior do pensamento marxiano, as circunstâncias objetivas não se reduzem à esfera econômica da vida, representando, ao contrário, a "unidade cotidiana das pessoas” ${ }^{22}$, ou seja, o processo real de suas vidas.

O argumento exposto acima poderia já indicar as críticas à segunda crítica lançada à concepção materialista histórico-dialética com relação à dimensão do sujeito: o pensamento marxiano ao compreender o sujeito como uma síntese das relações sociais - coletivas - isto é, ao entender que a formação de cada indivíduo seja uma formação social e socialmente condicionada, coloca em evidência a dimensão do social e nega a própria dimensão do sujeito. O debate sobre a relação social e individual, coletivo e sujeito, deve ser estabelecida a partir da própria concepção de social que possuímos. Como argumenta Vigotski:

[...] a psicologia social não marxista entende o social de modo grosseiramente empírico, necessariamente como multidão, coletivo, relação com outros indivíduos. A sociedade aí é entendida como reunião de pessoas e condição suplementar da atividade de um indivíduo. Esses psicólogos não admitem a idéia de que, no movimento mais íntimo e pessoal do pensamento, do sentimento etc., o psiquismo de um indivíduo particular seja efetivamente social e socialmente condicionado. (2001, pp. 13/14).

Queremos ressaltar com isto que a concepção marxiana de homem e de formação humana, não só considera com justeza a dimensão material das relações sociais historicamente produzidas, elegendo aí o trabalho como categoria central, como nos possibilita compreender a especificidade e a importância do sujeito nessa relação. Ainda que Marx e Engels não tivessem como objeto central de suas análises a dimensão psicológica da formação de cada sujeito, essa dimensão está presente em sua teoria e serviu de base para as reflexões e elaborações sobre a formação do psiquismo humano levado a cabo pela psicologia histórico-cultural ${ }^{23}$.

Leontiev, Vigotski, Davidov, Elkonim, Luria e outros psicólogos soviéticos, que tinham como fundamento de seus trabalhos uma concepção materialista histórico-dialética do mundo, procuraram compreender a formação humana e os conceitos psicológicos próprios àquela concepção de mundo. É neste movimento de produção de conhecimento que a categoria de Atividade (Leontiev, 1983; 1978; 1991) pôde ser elaborada.

\footnotetext{
${ }^{22}$ Marx e Engels, apud Leontiev 1983.

${ }^{23}$ Sobre o movimento de elaboração da Psicologia Histórico-Cultural (ou Psicologia Soviética, ou Escola de Vigotski), ver Matha Shuare (1990), que explicita tanto as fundamentações filosóficas e epistemológicas dessa teoria, quanto os principais conceitos elaborados em seu interior.
} 
A categoria filosófica de atividade é considerada por Davidov (1988) como a abstração teórica de toda a prática humana universal que tem caráter histórico-social. Trata-se de uma generalização da relação essencial do homem com o mundo, relação essa que permitiu e permite a transformação da natureza (do mundo externo) concomitantemente à transformação do próprio homem (sua conduta). Essa relação essencial é o trabalho. Como já mencionado nesta pesquisa (capítulo 2), ao agir sobre o mundo, o homem produz não apenas sua vida biológica e, amplamente, a sua vida social, mas, também, a sua vida psíquica.

O trabalho é, assim, uma atividade própria do homem, a forma específica dele se relacionar com o mundo. Entendido como a relação dialética entre objetivação e apropriação, o trabalho expressa a dinâmica essencial de autoprodução do homem pela sua atividade social.

Como resultado desse processo, temos que o homem (singularidade), por meio do trabalho e sob determinadas condições sociais que dão uma forma específica a essa sua relação fundamental com o mundo (particularidade), humaniza-se, produz-se a si mesmo enquanto um ser cultural e torna-se parte do gênero humano (universalidade).

A apropriação do processo de trabalho pelo homem permitiu que ele assumisse uma postura perante a natureza de criador; ele passou cada vez mais a exigir ou a forçar que a natureza lhe desse o que ele queria. Desta forma, por realizar na natureza seus desejos, ou mais precisamente seus fins, o homem objetivou-se no mundo, humanizou os objetos e o mundo e nesse processo pode humanizar-se a si próprio. Portanto, o trabalho permitiu ao homem transformar a natureza e criar um mundo humano; o trabalho permitiu, ainda, que ele transformasse a si próprio, criando novas formas de conduta, condutas especificamente culturais (VYGOTSKI, 1995).

A utilização de instrumentos na relação homem-mundo ou, mais precisamente, a criação de uma atividade mediadora do homem com a natureza e consigo mesmo, surgida no trabalho e pelo trabalho, permitiu ao homem prever ou antecipar o "efeito" de suas ações. O efeito antecipado transformou-se em propósito (FISCHER, 1976). O propósito ou finalidade passou a estar presente durante todo o processo de trabalho, governando e condicionando o trabalhador (suas formas de conduta, que deveriam estar subordinadas aos propósitos estabelecidos). A ação do homem e sua forma de conduta passam a ser conscientes: $o$ homem sabe o que quer antes de começar a agir, e age do princípio ao fim, de acordo com o propósito que colocou para si próprio.

O fato do homem prever, antecipadamente, o resultado de seu trabalho, de ter o produto de seu trabalho pronto na sua mente antes de iniciar a sua atividade propriamente 
dita, significou uma mudança sumamente importante no seu comportamento; possibilitou, em última análise, que ele controlasse conscientemente seus atos, direcionando sua conduta para a objetivação daquele seu propósito, que antes só existia na sua mente. O homem, por ter suas ações e condutas direcionadas e organizadas por si próprio, ou seja, por ter uma "ação consciente”, passou a ser, também, um “ser consciente” (FISCHER, 1976).

Esta dimensão geral e humanizadora do trabalho está sintetizada na categoria Atividade elaborada no interior da Psicologia Histórico-Cultural. A Atividade é, assim, uma forma de compreender, por meio de uma análise psicológica do processo de formação humana, a maneira como as relações sociais, as condições materiais de produção e reprodução da vida concreta, de fato se manifestam em cada sujeito singular e na humanidade de uma maneira geral. As relações sociais não se realizam diretamente nos indivíduos, mas são sempre mediadas pelas atividades nas quais este indivíduo toma parte. Como diz Leontiev: “As circunstancias objetivas criam a personalidade, mas sempre por meio de um conjunto de atividades por cujo intermédio se opera sua relação com o mundo”. (1983, p.178).

Desta forma, a relação sujeito/relações sociais, ganha um mediador: as atividades humanas, por meio das quais a dimensão do singular (o sujeito) se manifesta e produz a si mesmo enquanto gênero humano. A atividade passa a ser o elemento mediador entre as circunstâncias materiais objetivas e as ações do sujeito. É através da atividade, nela e por meio dela, que as condições objetivas da vida (as relações sociais) se manifestam para cada sujeito. Porque somente estando em atividade, ou mais precisamente em um conjunto de atividades relacionadas entre si, é que os sujeitos irão ocupar um determinado lugar e um determinado papel nas relações sociais que, assim, irão efetivamente exercer um lugar determinante em suas vidas. A categoria atividade torna-se, assim, a categoria central ou a unidade de análise da formação das funções psicológicas e da personalidade de cada sujeito.

A partir desta concepção podemos afirmar o caráter histórico do desenvolvimento humano. O homem só pode ser compreendido historicamente, isto é, em relação com o desenvolvimento da sociedade, com o desenvolvimento das condições objetivas de vida e com as diversas atividades engendradas nela. A maneira como a humanidade foi produzindo a sua existência (o seu modo de vida) é, em grande medida, a chave para compreendermos as formas de agir, pensar, emocionar-se etc, desenvolvidas pela humanidade e em cada sujeito ${ }^{24}$. Entretanto, como já vimos, o revelar dessas dimensões da conduta humana não ocorre de uma

\footnotetext{
${ }^{24}$ As transformações nos processos psíquicos não são apenas e fundamentalmente regionais ou étnicas, mas sim fruto de transformações no modo de vida da humanidade, nas relações sociais mais amplas. O desenvolvimento cultural de cada sujeito não tem a ver apenas ou essencialmente com as dimensões do particular, mas, sobretudo, com a dimensão do universal.
} 
maneira direta, apenas revelando as condições sociais mais gerais de uma dada época. E isso não ocorre porque as condutas mesmas não são produtos diretos ou imediatos dessas condições gerais, mas são mediadas pelas atividades nas quais os sujeitos tomam parte e efetivamente se relacionam com o mundo, com os outros e consigo mesmo. Como diz Marx (1996, p.56) "as circunstâncias fazem o homem na mesma medida em que os homens fazem as circunstâncias".

Deste modo, as investigações voltadas para a produção de conhecimento na esfera da formação humana, da sua personalidade e das funções psíquicas, referenciadas no materialismo histórico-dialético, devem ter como categoria central a atividade (ou o conjunto de atividades) que os sujeitos realizam. Neste processo de análise é preciso revelar a estrutura dessas atividades (ela mesma, condicionada pelas circunstancias objetivas da vida em sociedade), para, então, explicitar as dimensões propriamente psicológicas da atividade do sujeito. Como diz Leontiev "O nosso método geral consiste, portanto, em encontrar a estrutura da atividade humana engendrada por condições históricas concretas, depois, a partir desta estrutura, por em evidência as particularidades psicológicas da estrutura da consciência dos homens”. (1978, p.100).

O estudo da estrutura da atividade humana em geral, os elementos que a compõem e as relações entre estes elementos, faz-se fundamental para compreendermos os diversos tipos de atividades existentes hoje e suas implicações na constituição dos indivíduos. É preciso, em primeiro lugar, especificar a que se refere o conceito de atividade na Psicologia HistóricoCultural, ou seja, definir o que pode ser compreendido como atividade ou em que medida uma esfera da vida humana pode ser compreendida realmente como uma atividade.

\footnotetext{
Não chamamos todos os processos de atividade. Por esse termo designamos apenas aqueles processos que, realizando as relações do homem com o mundo, satisfazem uma necessidade especial correspondente a ele.[...]

Por atividade, designamos os processos psicologicamente caracterizados por aquilo a que o processo como um todo, se dirige (seu objeto), coincidindo sempre com o objetivo que estimula o sujeito a executar esta atividade, isto é, o motivo (LEONTIEV, 1991, p.68).
}

A atividade possui alguns elementos que se relacionam entre si: motivos, necessidades, objetos, objetivos, ações e operações. Mas a sua estrutura como um todo não se define por uma simples justaposição destes elementos; define-se por uma combinação ou uma relação específica entre eles, que revela a dinâmica mesma dos sujeitos em atividade. Os elementos que compõem a estrutura da atividade são, assim, àqueles que os sujeitos devem lidar em suas vidas para realizar as atividades em que estão envolvidos (ou que irão se 
apropriar) e que revelam a forma como a humanidade lidou com esses elementos, isto é, revelam as necessidades e os problemas surgidos e as respostas que foram sendo encontradas.

Explicitemos, agora, a estrutura da atividade e a inter-relação de seus elementos. Uma atividade se constitui como tal, em primeiro lugar, pela existência nela de um motivo; o motivo origina e dirige a atividade. O motivo, contudo, só existe quando uma necessidade se concretiza em um determinado objeto. Ainda assim, para que a necessidade se satisfaça, é necessário que o sujeito persiga determinados objetivos e os realize mediante ações, ações essas orientadas pelas condições de realização das mesmas, isto é, pelas operações.

Analisemos um exemplo ilustrativo a respeito dos elementos componentes da estrutura da atividade. Em nosso exemplo, imaginaremos que um sujeito tenha a necessidade de conhecer um determinado fenômeno. Como mencionamos, para que essa necessidade possa ser satisfeita é preciso que ela se concretize em um objeto adequado à necessidade em questão. À necessidade do conhecimento (assim como diversas outras necessidades humanas) não corresponde apenas um único objeto capaz de satisfazê-la; e não corresponde porque o homem mesmo foi criando, para si, outros e novos objetos capazes de satisfazer suas necessidades. Desta forma, o sujeito de nosso exemplo poderia encontrar a satisfação de sua necessidade olhando ou observando diretamente o fenômeno a ser conhecido; neste caso, o objeto de satisfação da necessidade de conhecer é o próprio objeto, o objeto em si. O mesmo sujeito poderia, entretanto, satisfazer sua necessidade a partir do contato com as experiências e sínteses de outras pessoas materializadas em livros; neste caso, o objeto que concretizaria a necessidade seriam os conceitos sobre o objeto e não mais o objeto em si. Em cada um dos dois modos de satisfazer a necessidade do conhecimento, temos uma modificação do objeto no qual a necessidade irá se concretizar, embora a necessidade mesma (em seu aspecto mais geral) permaneça a mesma. Mas essa diferença dos objetos leva a formas também distintas de satisfação da necessidade; cada qual cria para o homem um motivo específico: conhecer observando ou conhecer lendo e imaginando.

Definido, então, o motivo daquela atividade, falta ao sujeito, ainda, levar a cabo a satisfação da mesma, transformar o propósito estabelecido em ações. Vamos imaginar, agora, que o sujeito de nosso exemplo queira conhecer os conceitos daquele determinado fenômeno através da leitura. Para isso, ele terá de organizar e concretizar determinadas ações: encontrar algum documento escrito que traga o conteúdo pretendido; realizar a leitura propriamente dita do documento; realizar uma síntese da leitura, explicitando os pontos mais importantes para se compreender o fenômeno em questão. Em outras palavras, ele precisará realizar operações de análise e síntese do objeto a ser conhecido. Somente com as ações reais (que são de ordem 
tanto físicas, quanto psíquicas) é que a necessidade poderá ser, de fato, satisfeita. Mas as ações, por sua vez, não ocorrem em si mesmas: elas estão sempre relacionadas a determinadas condições concretas, a determinadas circunstâncias que nos fazem realizar as ações de um modo ou de outro. Em nosso exemplo, as circunstâncias das ações para a leitura indicam para o sujeito as operações que terá de lidar: se o livro está em sua casa ou na biblioteca; se é uma versão digitalizada em que é possível fazer anotações diretamente na tela do computador, ou se se trata de um exemplar impresso em que é preciso realizar anotações em uma folha a parte; se está em língua materna ou em outra língua etc, todas essas condições objetivas de suas ações, resultam nas operações que o sujeito lidará em sua atividade.

A atividade é, assim, um "processo originado e dirigido por um motivo, dentro do qual tomou a forma de um objeto uma determinada necessidade” (LEONTIEV, 1983 p.145). O homem possui diversas necessidades, porém a necessidade em si mesma não pode ser satisfeita: ela precisa de um objeto. Até que se satisfaça pela primeira vez, a necessidade não conhece seu objeto. Quando o conhece, ganha o seu caráter objetal: vira motivo e ganha função estimuladora e retora da atividade.

A primeira condição de toda a atividade é uma necessidade. Todavia, em si, a necessidade não pode determinar a orientação concreta de uma atividade, pois é apenas no objeto da atividade que ela encontra a sua determinação: deve, por assim dizer, encontrar-se nele. Uma vez que a necessidade encontra a sua determinação no objeto (se "objetiva" nele), tal objeto tornase motivo da atividade, aquilo que o estimula (LEONTIEV, 1978, p.115).

Realizar uma atividade significa que todos os seus processos (ações e operações) se dirigem à atividade. A necessidade que se concretiza mediante um objeto, dirige todo o processo de sua atividade, posto que se transforma em um motivo.

As ações nem sempre coincidem com o objetivo da atividade, já que para a necessidade se concretizar diferentes objetivos podem ser postos para o sujeito. Tais objetivos são concretizados pelas ações. A ação relaciona-se diretamente com os objetivos que visa concretizar, mas segue se relacionando (indiretamente) com o motivo da atividade, dado que só tendo ele como referência a atividade pode se realizar. O objetivo, por si só, não estimula o sujeito a agir; é preciso que o objetivo apareça para o sujeito vinculado com o motivo da atividade da qual faz parte. O motivo de uma ação, assim, está na atividade da qual ela faz parte. E para que as ações possam ser realizadas, por sua vez, é necessário ter em conta as condições sob as quais as mesmas poderão ser realizadas, isto é, as operações. 
Entender os elementos que compõem a atividade e, sobretudo, a relação entre eles é fundamental para podermos compreender o processo de produção de novas atividades, tanto de um ponto de vista filogenético, quanto ontogenético. Uma nova atividade surge quando o homem cria, ou se apropria, de um novo motivo - uma nova necessidade concretizada em um novo objeto. Neste sentido, podemos ter um movimento que vai das ações para a atividade: uma determinada ação ascende à categoria de atividade, posto que seu objetivo, tornou-se motivo. Este é o caso das ações de decoração dos instrumentos produtivos no homem préhistórico. De objetivo, pôde tornar-se o motivo mesmo do homem e, assim, originar uma nova atividade (atividade artística).

Da mesma forma, pode ocorrer um processo inverso: uma atividade torna-se uma ação. Isto ocorre quando o motivo daquela atividade é deslocado para a função de objetivo e a atividade, torna-se uma ação, subordinada a um outro motivo (e, portanto, a uma outra atividade). Esse seria o caso do estudo para o professor. O estudo que era para ele, enquanto aluno, uma atividade (seu motivo era aprender, se apropriar daqueles conhecimentos), passa a ser uma ação em sua nova atividade (atividade de trabalho, ou mais especificamente, de ensino).

Há uma relação particular entre atividade e ação. O motivo da atividade, sendo substituído, pode passar para o objeto (o alvo) da ação, com o resultado de que a ação é transformada em uma atividade. Este é um ponto excepcionalmente importante. Esta é a maneira pela qual surgem todas as atividades e novas relações com a realidade. Esse processo é precisamente a base psicológica concreta sobre a qual ocorrem mudanças na atividade principal e, conseqüentemente, as transições de um estágio do desenvolvimento para o outro (LEONTIEV, 1991, p.69).

A mesma relação pode ocorrer também entre as ações e as operações. Uma ação, tornando-se automatizada ou inserindo-se em outras ações, pode virar uma operação. Caso de todos as nossas ações que estão automatizadas (escrever, por exemplo), mas que não deixam de ser conscientes para o sujeito, sempre que necessária.

O surgimento de novas atividades na história da humanidade e no processo de desenvolvimento de cada indivíduo ocorre porque os elementos acima descritos da atividade são mutáveis: uma ação pode se converter em uma operação (caso haja um novo propósito para a realização dessa ação e ela passe a desempenhar o papel de meio para realizar uma outra ação); o motivo da atividade, ao passar para o objetivo (o alvo) da ação, faz com que a ação se transforme em uma atividade. Neste movimento surgem todas as novas atividades 
humanas e, portanto, as novas formas do homem se relacionar com a realidade (com o mundo, com os outros e consigo mesmo).

\subsection{A categoria atividade e a educação escolar.}

Considerando, então, a categoria Atividade como aquela que pode expressar, de um ponto de vista psicológico, a relação geral e essencial do homem com o mundo - que imprime nele as suas intencionalidades e, nesse processo, modifica o mundo e a si próprio consideramos que se trata, também, da categoria central para analisarmos os processos formativos dos sujeitos no campo pedagógico.

Pautados nessa perspectiva, a investigação dos processos formativos do professor e sua constituição como sujeito, vem sendo pesquisada e compreendida nas pesquisas produzidas pelo GEPAPe ${ }^{25}$ a partir e por meio da análise das relações reais e concretas que o sujeito estabelece com o mundo, isto é, através da análise da sua atividade principal: a atividade de ensino. Algumas pesquisas desenvolvidas e que buscaram investigar a formação docente a partir dessa perspectiva teórica, procuraram analisar o movimento de constituição da atividade de ensino através da análise e inter-relação de seus componentes, (notadamente o motivo), quer investigando a relação do sujeito ao longo de sua vida com a atividade de ensino (ASBAHR, 2005), quer desenvolvendo situações que possibilitassem ao sujeito a tomada de consciência da atividade de ensino, criando neles novas necessidades e novos motivos (CEDRO, 2008; MORETTI, 2007).

Outras pesquisas vêm centrando suas investigações nos processos formativos dos educandos, compreendendo este movimento a partir da atividade principal do sujeito em idade escolar: a atividade de estudo. Nessas investigações, busca-se criar necessidades e motivos que insiram o aluno em atividade de estudo, organizando as ações discentes e docentes para tal (BERNARDES, 2000; CEDRO, 2004; SFORNI, 2003; PANOSSIAN, 2008).

Deste modo, a atividade do sujeito no campo pedagógico (atividade de ensino, atividade de estudo ou atividade de jogo) passa a ser o elemento fundamental de análise e/ou de intervenção do pesquisador, em seu percurso de elaboração de conhecimentos sobre os

${ }^{25}$ O Grupo de Estudos e Pesquisa sobre a Atividade Pedagógica tem como fundamentação para as suas atividades de estudo e pesquisa a teoria histórico-cultural e a Teoria da Atividade, ambas pautadas no materialismo histórico-dialético. Este grupo vem produzindo teses, dissertações e artigos que buscam investigar as condições e os processos para a transformação dos sujeitos no trabalho pedagógico e em suas atividades principais: a atividade de estudo (para os educandos) e a atividade de ensino (para os educadores). 
processos de formação dos sujeitos, em nossa atual sociedade, como membros do gênero humano.

\subsubsection{O trabalho educativo}

As diversas atividades humanas resultam sempre em uma modificação concreta do mundo e dos homens que dela tomam parte. As ações dos homens no mundo, modificando e/ou criando outros objetos (materiais e não materiais), fazem com que as suas intencionalidades fiquem "gravadas" no mundo e, assim, disponíveis para outros homens. Mas tais intencionalidades e capacidades humanas, não estão disponíveis apenas pelo contato com o objeto que a encarne; é preciso apropriar-se desse objeto. Tal apropriação ocorre mediante a reprodução, pelo individuo, da atividade que gerou o referido objeto.

\footnotetext{
Mesmo os instrumentos ou utensílios da vida quotidiana mais elementares têm de ser descobertos ativamente na sua qualidade específica pela criança quando esta o encontra pela primeira vez. Por outras palavras, a criança tem de efetuar a seu respeito uma atividade prática ou cognitiva que responda de maneira adequada (o que não quer dizer forçosamente idêntica) à atividade humana que eles encarnam. Em que medida a atividade da criança será adequada e, por conseguinte, em que grau a significação de um objeto ou de um fenômeno lhe aparecerá, isto é outro problema, mas esta atividade deve sempre produzir-se (LEONTIEV, 1978, pp. 166-167).
}

Neste sentido, Leontiev (1978) ressalta, também, o caráter fundamentalmente educativo do processo de apropriação. Para se apropriar de um objeto ou de um fenômeno, o homem deve entrar em relação com ele. Para entrar em relação com o objeto ou fenômeno, o homem precisa entrar em relação com os outros homens, ou seja, tomar parte de um processo de comunicação, a fim de aprender a atividade adequada para se apropriar do objeto ou fenômeno em questão. Não há apropriação (e não há aprendizagem) realizada por um indivíduo isolado, explorador do mundo que o cerca.

Todas as funções psíquicas superiores são relações interiorizadas de ordem social, são o fundamento da estrutura social da personalidade. Sua composição, estrutura genética e modo de ação, em uma palavra, toda sua natureza é social, inclusive ao converter-se em processos psíquicos segue sendo quase social. O homem, inclusive sozinho consigo mesmo, conserva funções de comunicação (VYGOTSKI, 1995, p.151). 
Mas isso não quer dizer que exista apenas um modo de nos apropriarmos das coisas, de aprendermos; justamente porque cada sujeito está inserido em uma atividade concreta, e inserido concretamente com todo o seu ser, os objetos ou fenômenos a serem apropriados poderão adquirir para ele diferentes sentidos pessoais (LEONTIEV, 1978). Como ressalta Leontiev (1978), realizar uma atividade adequada ao objeto não significa reproduzir mecanicamente e copiosamente a atividade que lhe deu origem, mas tão somente a estrutura essencial da atividade em questão.

Neste sentido, então, que podemos compreender a educação (de uma maneira geral) como um processo de transmissão e assimilação da cultura já produzida; é a maneira que a humanidade criou para que cada sujeito possa herdar aquelas aquisições culturais produzidas historicamente pela humanidade em seu conjunto e objetivadas nos fenômenos e objetos materiais.

Interessa-nos trabalhar não só ou não diretamente com o conceito de educação em geral, mas fundamentalmente com o de educação escolar. Interessa-nos abordar os processos de aprendizagem que se dão por meio da apropriação de um conhecimento específico (o conhecimento teórico), mediante a inserção do sujeito em atividade de estudo, atividade essa organizada intencionalmente por quem ensina, através da atividade de ensino.

A nossa própria intencionalidade pedagógica, enquanto educadores e enquanto pesquisadores, está mediada por uma concepção de educação alicerçada na Pedagogia Histórico-Crítica, pedagogia essa que tem por fundamentação o materialismo histórico dialético.

[...] o trabalho educativo é o ato de produzir, direta e intencionalmente, em cada indivíduo singular, a humanidade que é produzida histórica e coletivamente pelo conjunto dos homens. Assim, o objeto da educação diz respeito, de um lado, a identificação dos elementos culturais que precisam ser assimilados pelos indivíduos da espécie humana para que eles se tornem humanos e, de outro lado e concomitantemente, à descoberta das formas mais adequadas para atingir esse objetivo (SAVIANI 1995, p.17).

A conceituação de Saviani a respeito do trabalho educativo nos parece não apenas coerente com o materialismo histórico dialético, mas também com os próprios pressupostos da teoria histórico-cultural. Em primeiro lugar, explicita-se a necessidade de garantir que cada indivíduo aproprie-se, faça seu, àquelas capacidades que a humanidade - ao longo da sua historia - já produziu e que constituem, hoje, capacidades do gênero humano. Este 
posicionamento pontua a existência de uma relação entre o singular-particular-universal ${ }^{26}$, fundamental em uma época em que o ensino que temos é considerado como sendo as máximas possibilidades já desenvolvidas pela humanidade (o universal), uma vez que corresponde às necessidades "reais” de nossa sociedade. Mas se esquece que essas necessidades reais, não são as necessidades verdadeiramente universais, mas sim as particulares.

Em segundo lugar, a conceituação do trabalho educativo elaborado por Saviani pontua a necessidade de se identificar àquilo que é essencial de ser apropriado pelos sujeitos na escola: quais conhecimentos são essenciais para que eles se formem enquanto membros do gênero humano. Essa discussão nos remete tanto para a valorização do conhecimento sistematizado ou teórico na escola, quanto para a valorização de um posicionamento ético, ao se eleger determinados conhecimentos (ou modos de conhecer o mundo) e não outros.

Por fim, pontua-se a necessidade de imprimir esse processo de ensino de intencionalidade por parte de quem ensina. Para nós, isso tem a ver com a organização do ensino em forma de atividade, inserindo os educandos em atividade de estudo para que, nesse processo, possamos criar neles a necessidade de conhecer teoricamente o mundo.

Falar em criar necessidades nos educandos pode nos remeter a duas questões em debate no campo educacional hoje. Uma delas refere-se ao trabalho com as necessidades dos alunos, trabalhar a partir de suas necessidades ou interesses. A segunda, intimamente vinculada com a primeira, refere-se à criação de um ensino e de uma aprendizagem que sejam significativas. Essas questões nos parecem, de fato, pertinentes dentro das discussões do trabalho educativo.

Se pensamos e queremos que os educandos sejam sujeitos ativos em seus processos de aprendizagem, é preciso, sim, considerar os interesses que eles apresentam e é preciso, sim, tornar o ensino significativo para eles. Mas essa aceitação geral, ou podemos dizer, essa necessidade geral da organização do ensino, só pode ser verdadeiramente avaliada quando concretizamos essa necessidade em um objeto e, assim, encontramos o motivo do trabalho pedagógico.

Por um lado, podemos nos preocupar fundamentalmente em preparar os educandos para essa sociedade em que ele vive, e mais especificamente para a vida que ele e a sua comunidade levam. Diante deste objeto as necessidades ou interesses dos educandos são aquelas mais imediatas e pragmáticas. Por outro lado, podemos nos preocupar,

\footnotetext{
${ }^{26}$ Sobre esta relação ver o trabalho de Betty Oliveira, “A dialética do singular-particular-universal”, 2005.
} 
fundamentalmente, em formar os educandos para uma outra sociedade possível, o que implica em formá-los dentro das máximas possibilidades do gênero humano; formá-lo para capacides e modos de ação que não lhe pertencem imediatamente, mas que devem lhe pertencer enquanto membro do gênero humano. Diante deste objeto, os interesses dos educandos não são os interesses de um aluno empírico (ou aluno em si), mas os interesses de um aluno concreto (porque síntese das múltiplas relações sociais).

As necessidades do aluno, enquanto indivíduo, de um grupo de estudantes ou mesmo de uma escola toda, não são critérios definidores do que deva ser ensinado nessa escola para esses educandos.

Os conhecimentos a serem trabalhados são um produto universal que assume contornos e especificidades particulares, conforme as regiões ou as necessidades locais. Esses produtos da humanidade são comuns, uma vez que comum é a prática social de uma dada sociedade, comuns são as necessidades sociais, as grandes questões que são enfrentadas (GASPARIN, 2002 p.39).

Trabalhar com os interesses de um aluno concreto significa trabalhar com aqueles conhecimentos que o vinculem ao gênero humano; com aqueles conhecimentos em que ele possa cada vez mais ir se descobrindo como um ser em-si e um ser para-si. Significa trabalhar com aqueles conhecimentos que não fazem parte da realidade imediata do estudante, mas que, mesmo assim, lhe pertence (ou que deve lhe pertencer) porque fazem parte do gênero humano. A partir dessa perspectiva, podemos compreender o ensino como "ensino significativo".

Desta forma, a ação primeira do educador é transformar o ensino em atividade significativa. E fazer isto é dar oportunidade para que o aluno tome a ação de aprender como uma necessidade para integrar e ter acesso a novos conhecimentos. E mais: que a criança ou o aprendiz perceba o conhecimento como uma referência no processo de humanização, cujo passo inicial é a compreensão do conjunto de saberes produzidos como patrimônio da humanidade (MOURA, 1996, p.34).

Nesta perspectiva defendida, o conhecimento ou o conteúdo de ensino, ganha um papel preponderante na atividade educativa. E uma vez que o conhecimento ganha esse papel de destaque, acaso não estaríamos indo contra a defesa de uma educação na qual o educando deva ocupar o centro do processo educativo?

Essa idéia precisa ser, ela mesma, analisada. Podemos tomar como verdadeiro este princípio do “educando como centro do trabalho pedagógico" se o considerarmos sob o ponto de vista da finalidade do processo educativo: contribuir para a humanização de cada indivíduo 
e sua constituição como sujeito. Sendo assim, a atividade pedagógica como um todo se volta para que os educandos sejam cada vez mais humanos, por meio da apropriação da cultura historicamente elaborada. Neste sentido, sim, o aluno pode ser considerado o centro do processo, ao qual todas as ações devem se destinar.

Entretanto, ao considerarmos a atividade pedagógica em termos de sua organização ou estrutura e não mais em termos do "para que ela está voltada", o aluno não é o seu centro e não o pode ser. Para que o educando possa se constituir como sujeito do processo educativo, formar-se enquanto estudante e, assim, apropriar-se da cultura (mais especificamente do conhecimento teórico), o educador deve organizar a própria atividade do aluno, o que inclui as suas ações e, principalmente, a necessidade de conhecer e se relacionar com o mundo teoricamente. Disso decorre que o aluno não é o centro de onde partem as demais ações. Se assim o fosse, estaríamos lidando com os seus interesses empíricos.

Poderíamos nos deter, ainda, a mais uma questão com relação a nossa concepção de educação: ao se enfatizar o conhecimento no processo de ensino e de aprendizagem, não estaríamos enfatizando sobremaneira a questão da transmissão dos conhecimentos, minimizando, assim, o papel dos educandos enquanto sujeitos de sua aprendizagem? Entendemos que o que está em jogo para que ocorra a aprendizagem não é a transmissão direta do conhecimento do professor para o aluno (falando, lendo etc), mas a organização pelo professor de determinados conhecimentos em forma de atividade, isto é, que permitam ou obriguem que cada educando se insira em uma atividade e, assim, exerça seu papel de sujeito de sua aprendizagem.

Podemos inferir que o desenvolvimento psíquico da criança não é necessariamente desencadeado quando ela é formalmente ensinada ou fica estanque quando não é ensinada por um indivíduo em particular, mas quando passa a participar de uma atividade coletiva que lhe traz novas necessidades e exige dela novos modos de ação. É a sua inserção nessa atividade que abre a possibilidade de ocorrer um ensino realmente significativo (SFORNI, 2003, p.95).

A finalidade do trabalho educativo, então, passa a ser a de criar nos educandos uma nova necessidade - a necessidade do conhecimento teórico - garantindo a satisfação da mesma por meio de sua organização, que irá mobilizar os educandos para a atividade de estudo. O educando torna-se sujeito da aprendizagem, sujeito ativo, porque se insere em uma atividade coletiva, apropria-se de novas necessidades e cria para si um motivo. O educador organiza o conhecimento teórico necessário de ser transmitido para as novas gerações por meio da atividade de ensino, que tem nos educandos o seu fim, ou o seu produto. 
No processo de educação que realmente se efetivou, o educando sai do processo diferente do que entrou, sai indivíduo educado.

O produto do trabalho pedagógico é, dessa forma, a transformação da personalidade viva do aluno e essa transformação não permanece apenas no ato de ensinar/aprender, mas por toda a vida do indivíduo. Há, portanto, separação entre produto e consumo, o aluno continua consumindo o que aprendeu no decorrer de sua vida, pois no processo de aprendizagem o indivíduo apropriou-se de um saber que nele estará incorporado (ASBAHR, 2005, p.30).

A transformação da personalidade viva dos educandos aproxima-nos do conceito e da finalidade educativa mais geral presente no materialismo histórico-dialético: contribuir para a humanização de cada sujeito.

No sentido mais geral da palavra humanização, isto é, no sentido de se fazer homem cultural, de se apropriar das objetivações materiais e não materiais que a humanidade já produziu, todos os homens que vivem em sociedade, que vivem em um mundo de relações produzidas pelos próprios homens, se humanizam. Mas como compreender humanizações tão distintas, quanto a que, por exemplo, passou Gandi e a que passou Hitler? (apenas para utilizarmos exemplos mais consensuais da história). Ou a que passou a Sem-Terra $\operatorname{Rose}^{27}$ e a que passou o Coronel Ubiratan ${ }^{28}$ ou o Coronel Mário Colares Pantoja e o Major José Maria de Oliveira $^{29}$ ?

Ocorre que a humanização pode ser uma humanização desumanizada. Marx (apud Vazquez, 1968) recorre ao exemplo da mercadoria para demonstrar essa relação. A mercadoria e a despeito de toda a sua aparência, é um objeto humano. Contudo trata-se, igualmente, de um objeto desumanizado, isto é, que impede o homem de ser mais homem, de se enriquecer humanamente. Para a mercadoria (e as relações sociais construídas a partir dela) a riqueza humana reduz-se a riqueza da posse material. Entender a riqueza humana como a “[...] riqueza de necessidades e relações consigo mesmo, com os demais e com a realidade” (VAZQUEZ, 1968, p.319) é inconcebível no mundo da mercadoria.

Nesta mesma lógica, podemos dizer que todos os homens viventes em nosso mundo social são, efetivamente, indivíduos que se humanizaram, ou seja, que se formaram culturalmente. Entretanto, muitos deles estão desumanizados; viveram e vivem um processo

\footnotetext{
${ }^{27}$ Agricultora da primeira grande ocupação de terra improdutiva, no Rio Grande do Sul, em 1985, período de transição política da ditadura, assassinada ou "morta" em estranhas condições. Para saber mais, ver filme, "Terra para Rose”, 1987.

${ }^{28}$ Responsável pela invasão e morte de centenas de presidiários na penitenciária do Carandiru (em São Paulo) em 1993.

${ }^{29}$ Estes últimos, comandantes da Polícia Militar responsáveis pelo massacre em Eldorado dos Carajás, que resultou em 19 Sem-Terra mortos e dezenas de feridos.
} 
de humanização que, contraditoriamente, os desumanizam. Estes homens e mulheres estão sendo impedidos de serem cada vez mais humanos e de se enriquecerem de necessidades e relações verdadeiramente humanas.

Esta contraditoriedade se faz possível porque o processo de humanização, a apropriação dos bens materiais e não materiais produzidos pela humanidade e que cada sujeito deve realizar para se formar como membro do gênero humano, ocorre sempre mediada pela sociedade da qual o sujeito faz parte. Em uma sociedade em que as características humanas vêm assumindo formas cada vez mais desumanizadas, considerá-las como "as características próprias” do homem (tomar o particular pelo universal), contribui enormemente para a formação de homens e mulheres humanos, porém desumanizados.

Assim, preocupar-se com a "transformação da personalidade viva dos educandos e dos educadores” tem para nós o significado de contribuir com o processo formação de sujeitos verdadeiramente humanizados; sujeitos que, ainda que tenham suas formações mediadas pela atual sociedade em que vivem (desumanizadora por essência), conseguem se relacionar com aquelas dimensões verdadeiramente humanas já produzidas pelos homens e mulheres ao longo da história; sujeitos que lutam pela construção de uma sociedade que supere a predominância de relações desumanizadas entre os indivíduos.

\subsection{A organização do trabalho educativo: a Atividade Orientadora de Ensino.}

A categoria atividade, como já vimos, não nasceu e não se vincula diretamente ao campo educacional. Ainda que alguns dos autores da Psicologia Histórico-Cultural se preocupem de forma mais explícita com a questão da aprendizagem e do ensino (Vigotski, Talizena, Davidov, Galperin) e que adotem os termos atividade de estudo e atividade de ensino (Elkonim, Davidov, Rubtsov), seus objetos de pesquisa seguem sendo os processos psicológicos relacionados ao ensino e a aprendizagem e não a organização do ensino propriamente dita.

Transpor a teoria da atividade para o campo educacional, ou mais exatamente, tê-la como fundamento, requer a elaboração de uma teoria mediadora. A teoria da atividade tem suas próprias necessidades, seus próprios objetos de estudo e instrumentos, os quais estão mais diretamente vinculados à área da Psicologia, aos problemas atrelados à formação do 
psiquismo $^{30}$. A educação, mais precisamente o trabalho educativo, possui necessidades, objetos e instrumentos que, ainda que se articulem sob muitos aspectos com a teoria da atividade e com a Psicologia Histórico-Cultural, apresentam determinadas especificidades. E essas especificidades não apenas necessitam de uma teoria mediadora, como não podem prescindir dela.

Pensamos que é indispensável, quando Vigotski é lido com olhos de educador, dizer qual o olhar que lançamos a essa obra. Precisamos ter autoconsciência de nossa leitura pedagógica. Não adianta fingir que essa mediação não existe. É mais frutífero torná-la consciente (DUARTE, 1996, p.32).

Em termos gerais, nossa mediação pedagógica é fundamentada na Pedagogia Histórico-Crítica, pedagogia essa que tem por fundamento filosófico o materialismo históricodialético. Como já analisamos em um momento anterior deste texto, a Pedagogia HistóricoCrítica nos parece apresentar diversos pontos de aproximação com a Psicologia HistóricoCultural, posto que compartilham de uma mesma concepção de homem, de mundo e de conhecimento. Sendo uma teoria no campo educacional, a Pedagogia Histórico-Crítica desenvolve alguns aspectos próprios, atrelados principalmente à organização do ensino e à elaboração de uma proposta didática (SAVIANI, 1997; GASPARIN, 2002; WACHOWICS, 1991).

Em termos específicos, nossa mediação pedagógica fundamenta-se na elaboração teórica do conceito de atividade orientadora de ensino (AOE), proposta originariamente por MOURA (1996; 2001), mas que vem sendo continuamente aprofundada pelas pesquisas no interior do GEPAPe ${ }^{31}$. Esta segunda mediação pedagógica nos parece se relacionar mais diretamente com a Teoria da Atividade, buscando, no interior do trabalho educativo, as necessidades, os objetos e os instrumentos da atividade de ensino dos professores e da atividade de aprendizagem dos educandos.

A atividade, na interpretação que fazemos desse conceito desenvolvido por Leontiev (1986), é fruto de uma necessidade que, para se realizar estabelece objetivos, desencadeia ações, elege instrumentos e, por fim, avalia se chegou a resultados adequados ao que era desejado. A atividade orientadora de ensino tem uma necessidade: ensinar; tem ações: define o modo ou

\footnotetext{
${ }^{30}$ Podemos citar como pesquisas nessa linha todas aquelas preocupadas com a investigação dos processos de desenvolvimento das funções psíquicas superiores (atenção voluntária, memória lógica; linguagem, voluntariedade) e da personalidade do sujeito em geral (formação da consciência e do sentido pessoal).

31 Além das teses e dissertações elaboradas pelos integrantes do GEPAPe citamos, a respeito, o artigo recém publicado “Atividade orientadora de ensino: unidade entre ensino e aprendizagem” (MOURA at al, 2010).
} 
procedimentos de como colocar os conhecimentos em jogo no espaço educativo; e elege instrumentos auxiliares de ensino: os recursos metodológicos a cada objetivo e ação (livro, giz, computador, ábaco, etc). E por fim, os processos de análise e síntese, ao longo da atividade, são momentos de avaliação permanente para quem ensina e aprende (MOURA, 2001, p.155, grifos do autor).

A atividade orientadora de ensino pode ser considerada como base teóricometodológica para a organização do ensino. A base teórica realiza-se, sobretudo, na teoria da atividade, isto é, na organização do ensino em forma de atividade (tanto para os educadores, quanto para os educandos). A base metodológica realiza-se no instrumental lógico-histórico que ela nos fornece para a organização dos conhecimentos a serem ensinados e aprendidos.

Pensamos que uma questão essencial da atividade orientadora de ensino seja o fato dela revelar e explicitar a intencionalidade do professor, especificando o percurso de ensino e de aprendizagem (as ações, operações, finalidades, necessidades), que o educador e os educandos irão passar. Neste processo, busca-se criar, nos educandos, a necessidade do conhecimento teórico. A atividade orientadora de ensino, então, tem como finalidade organizar a apropriação do conhecimento teórico em forma de atividade (no caso, atividade de estudo). Deste modo, ela contribui tanto para criar a atividade de ensino do professor, quanto para criar a atividade de estudo dos educandos. É nesta medida que ela se torna, também, unidade de formação dos educadores e dos educandos (MOURA, 1996, 2001). Ao colocá-los em atividade (atividade de ensino para um e de estudo para o outro), ela permite aos sujeitos iniciar um processo de transformação consciente de suas personalidades.

Uma segunda questão essencial da atividade orientadora de ensino é o fato dela ser uma forma peculiar de reconstituição de uma atividade humana. Quaisquer conhecimentos ou objetos produzidos pela humanidade foram produzidos em uma determinada atividade, isto é, sua gênese está intimamente relacionada a uma atividade humana: às necessidades e aos modos de ação correspondentes à concretização de tais necessidades. Apropriar-se de um determinado conhecimento significa apropriar-se da atividade que lhe deu origem.

Se um educando precisa se apropriar dos conhecimentos relacionados à atividade literária (digamos a poesia), ele precisará reproduzir a própria atividade em questão. Mas, tal reprodução será peculiar: ocorrerá em forma de atividade de estudo. Isso quer dizer que a atividade real ou originária (a poesia) deve ser reconstituída de modo a ressaltar os conhecimentos teóricos presentes na referida atividade, isto é, aqueles conhecimentos que permita ao sujeito compreender a essência dessa atividade; que lhe permita abstrair e dominar os elementos essenciais da atividade. Desta forma, a reconstituição de uma atividade 
elaborada pela humanidade (seja ela científica, artística, literária etc.) deve revelar o processo de construção dessas atividades e dos conhecimentos teóricos atrelados a elas; deve revelar as necessidades que surgiram para a humanidade e as respostas que os homens foram dando a elas. Assim, o aluno em atividade de estudo reproduz a atividade humana, historicamente elaborada, não necessariamente em todos os seus traços, mas sim naqueles que sejam fundamentais para a apropriação do conhecimento teórico presente nela e para a apropriação da realidade mesma, em sua essência. É este o sentido da peculiaridade da reconstituição da atividade por meio da atividade orientadora de ensino.

O objeto das ações dos educandos em atividade de estudo é o conhecimento teórico. Ao reproduzir uma atividade artística (digamos uma atividade circense ou literária), o educando não está realizando uma atividade circense ou literária propriamente dita, mas sim uma atividade de aprendizagem sobre o circo e sobre a poesia. Em ambas as atividades (a atividade real e a atividade real reconstituída em forma de atividade de estudo) o significado e a forma de relação do homem com o mundo se mantêm. Mas o motivo dos sujeitos para se engajarem em tais atividades muda. O educando, ainda que saiba que irá participar de um recital com as poesias que escreveu ou de uma apresentação circense para a comunidade escolar, sabe (porque está consciente da sua atividade) que se trata de uma atividade de estudo. O motivo para participar dela é menos o produto em si mesmo (a poesia e o espetáculo) e mais os conhecimentos ou modos de ação adquiridos nesse processo de produção; o motivo é apreender o mundo e as atividades humanas teoricamente, em suas múltiplas relações, apropriando-se dos conhecimentos e de modos específicos de aprendizagem. Em outras palavras: o papel social que ele ocupa é diverso do de um artista de circo ou de um poeta; a sua necessidade é distinta. E isto é o que fortemente determina o motivo da atividade para o sujeito.

Neste sentido, a atividade orientadora de ensino constitui-se em um modo geral de organização do ensino, cujo conteúdo principal é o conhecimento teórico e cujo objeto é a formação do pensamento teórico nos educandos.

A especificidade da atividade orientadora de ensino, como uma atividade de ensino, está no seu motivo-objetivo - motivo consciente (LEONTIEV, 1983). Enquanto os motivos-objetivos da atividade de ensino e aprendizagem se caracterizam na objetivação e na apropriação do conhecimento historicamente construído, o motivo-objetivo da atividade orientadora de ensino é, também, a organização do ensino capaz de proporcionar tal apropriação e objetivação de conhecimentos, compondo o seu objeto, a formação do estudante, o seu próprio desenvolvimento (DIAS, 2007, pp.38-39). 
Esse modo geral de organização do ensino (motivo da atividade orientadora de ensino) realiza-se a partir de um tipo específico de conhecimento: o conhecimento teórico. A partir da distinção entre o conhecimento empírico e o conhecimento teórico ${ }^{32}$ podemos analisar um segundo tipo de relação: entre os problemas de aprendizagem e os problemas concreto e prático.

De acordo com Rubtsov, (1996) o problema de aprendizagem configura-se quando fazemos o educando confrontar-se "com uma situação cuja solução em todas as variantes concretas pede uma aplicação do método teórico generalista” (p. 131). Isto quer dizer que os problemas de aprendizagem, de acordo com esse mesmo autor, focam na aquisição de formas de ações gerais, correspondentes ao pensamento teórico. A ação do educando é fundamentada em um modelo, em um modo geral de ação, que constituirá na orientação geral para completar as ações concretas relativas a uma classe de problemas. $\mathrm{O}$ aluno, assim, adquire um novo modo de orientação de suas ações, um novo princípio.

O segundo tipo de problema (concreto e prático) apóia a resolução do problema nas características ou nas condições específicas do problema em questão. É possível que alguns educandos adquiram um "modo geral de ação" com este tipo de aprendizagem, mas ela ocorrerá apenas em um momento posterior, após a resolução de diversos problemas específicos e como um produto secundário do ensino (o foco é a solução concreta dos problemas e não a aquisição de um modo geral de ação). Neste sentido, a aprendizagem por meio dos problemas concreto e prático se parece com o processo de aprendizagem ou aquisição de conhecimentos em situações comuns.

Os problemas de aprendizagem, então, permitem que os educandos adquiram as formas de ações gerais ou os procedimentos essenciais para a resolução de uma determinada categoria de problemas, seja quais forem as variações ou manifestações particulares que se apresentem. E esse processo é característico do pensamento teórico.

O educando, na escola, irá adquirir esse modo geral de ação reproduzindo uma atividade humana reconstituída em forma de atividade de estudo. Nesse percurso, ele vai tomando consciência do modo humano de produção do conhecimento em geral (o pensamento teórico, com os seus processos de análise e síntese do real) e daquele conhecimento em particular com o qual está trabalhando (da poesia, do circo, da indústria etc); em outras palavras, ele vai tomando consciência da história do conceito.

\footnotetext{
${ }^{32}$ No capitulo 3, esboçamos as conceituações sobre o pensamento empírico e o pensamento teórico.
} 
A dimensão histórica é considerada dentro da atividade orientadora de ensino como uma das formas de perceber o processo sócio-cultural do conceito; neste sentido significa conceber o conceito inserido em uma história na qual homens e mulheres, diante de necessidades objetivas, buscam e elaboram soluções (CEDRO, 2004, p.117).

Até aqui expomos os elementos mais gerais relacionados à atividade orientadora de ensino: o seu motivo e a sua necessidade (organizar o ensino em forma de atividade de estudo) e o seu conteúdo ou objeto (o conhecimento teórico). Iremos, agora, analisar a estrutura da atividade orientadora de ensino ou os elementos que a compõe, que cumprirão o papel de instrumentos para a organização do trabalho educativo.

Como qualquer atividade, a atividade orientadora possui, ela mesma, uma estrutura. Não nos referimos aqui à estrutura geral da atividade (necessidade, ações, operações...), mas a sua estrutura específica, diretamente relacionada à atividade de ensino e à organização da aprendizagem dos educandos. “A estrutura da atividade orientadora é a própria gênese do conceito: o problema desencadeador, a busca de ferramentas intelectuais para solucioná-lo, o surgimento das primeiras soluções e a busca de otimização dessas soluções” (MOURA, 1992, p.68).

A gênese do conceito é o ponto de partida para as ações dos educadores e dos educandos. Entretanto, essas ações ocorrem em momentos distintos: para o educador é um processo que antecede a atividade de aprendizagem dos educandos; para os educandos é um processo que se inicia juntamente com a atividade de aprendizagem.

Para organizar a atividade de estudo dos educandos fundamentado na atividade orientadora de ensino, o educador precisará percorrer, ele mesmo, a gênese ou a história do conceito que irá trabalhar com os estudantes. Ele precisa, assim, estudar a atividade humana que deu origem ao conhecimento teórico em questão, explicitando para si as necessidades surgidas nessa atividade e as respostas que a humanidade foi criando para suprir tais necessidades (as ferramentas teóricas ou as sínteses e as abstrações elaboradas). Este estudo inicial permitirá ao educador formular o problema desencadeador de aprendizagem, isto é, o conjunto das necessidades e ferramentas teóricas que permitiram a humanidade elaborar determinado conceito. Mas o problema desencadeador precisa, ele mesmo, ser desenvolvido para a organização do ensino. As necessidades e as ferramentas teóricas precisam ser postas em uma relação tal que o educador possa visualizar a sua atividade de ensino, bem como visualizar a atividade de aprendizagem dos educandos; o percurso pedagógico de ambos precisa ser esboçado e apenas o problema desencadeador não é capaz de concretizar isto. 
O problema desencadeador, portanto, não representa a estrutura da atividade orientadora como um todo. Ele é fundamental para o processo de organização do ensino, mas cumpre nele uma função apenas orientadora, tanto para a atividade de ensino do educador, quanto para a atividade de aprendizagem dos educandos. A importância fundamental dessa dimensão orientadora para a organização do ensino reside nos dois elementos que ela explicita para o educador.

a) As sínteses que a humanidade alcançou naquela atividade (portanto, a síntese que os educandos deverão se apropriar relacionadas às necessidades que lhe deram origem; o conceito em sua forma mais elaborada e como reflexo da realidade objetiva);

b) O caminho que a humanidade percorreu para chegar a essa síntese (as abstrações) com as quais os educandos deverão operar.

Esse movimento dá ao educador a dimensão histórica do conceito, o seu processo de produção. Tendo esse processo explícito para si, pode reelaborá-lo em forma de atividade de estudo para os educandos, ressaltando, dentro da atividade em questão, apenas aqueles caminhos e aquelas sínteses que sejam essenciais para a apropriação do conceito.

Para reelaborar a gênese do conceito ou o problema desencadeador em forma de atividade de estudo, o educador precisará esboçar o percurso de ensino e de aprendizagem que educador e educandos irão trilhar. Esse é o papel da situação desencadeadora de aprendizagem.

A situação desencadeadora de aprendizagem constitui-se, assim, em um elemento fundamental na estrutura da atividade orientadora de ensino, posto que ela desencadeia a necessidade de apropriação do conhecimento teórico (da história do conceito, das relações essenciais dele) pelo educando. O problema desencadeador proposto aos educandos na situação desencadeadora de aprendizagem direciona as ações dos estudantes para que elas sejam realizadas com base em um modo geral de ação (ou princípio generalizador) e para que sejam mobilizadas pelo motivo real desta atividade: a apropriação dos conhecimentos. Com esse processo o indivíduo terá desencadeado seu processo de aprendizagem. "Sendo assim, o objetivo do professor é levar a criança a dar forma ao modo teórico por meio do qual um problema pode ser solucionado em uma situação de aprendizagem, que é considerada como um problema de aprendizagem” (CEDRO, 2004, p.48).

A situação desencadeadora de aprendizagem possui uma dimensão mais executora, dentro da atividade de ensino do que orientadora, o que quer dizer que ao desencadear a necessidade de apropriação do conhecimento teórico, ela deve também explicitar as ações e as 
operações que os educandos deverão se envolver e que o educador deverá organizar para que os primeiros se apropriarem do conhecimento teórico trabalhado.

Deste modo, a situação desencadeadora irá explicitar as ações e operações de ensino (o plano de ação do educador) e as de aprendizagem (as tarefas dos educandos). As ações e as operações, como já vimos, são partes constituintes e fundamentais de qualquer atividade. São elas que permitem ao homem imprimir o mundo com a sua intencionalidade e transformar a realidade (material e não material) que o cerca.

As ações e as operações de ensino buscarão explicitar o percurso concreto pelo qual o professor irá passar durante o trabalho educativo, de modo a contribuir para organizar a atividade dos educandos em forma de atividade de estudo. As ações e as operações dos educandos apontarão o percurso que eles irão atravessar ao longo do trabalho educativo, o modo de trabalhar com as sínteses e as abstrações elaboradas pela humanidade, para a apropriação do conceito em questão.

As ações de aprendizagem, como vimos, devem se vincular a um problema de aprendizagem e fornecer um modo geral de resolução das diversas situações relacionadas ao problema elaborado. O problema de ensino proposto deve, ele mesmo, ser analisado não em sua particularidade pelos educandos, mas já em seus aspectos genéricos. A resolução do problema ocorrerá como um modo geral de ação.

Desta forma, as tarefas de aprendizagem dos educandos buscam criar neles a necessidade de se apropriarem dos conhecimentos teóricos. Isto quer dizer que a parte orientadora da atividade, (motivo; necessidade; problema desencadeador de aprendizagem) vincula-se orgânica e constantemente com a sua parte executora (ações; operações; situação desencadeadora de aprendizagem).

Outro ponto característico da AOE é que a elaboração da atividade de ensino e a solução da situação-problema pelos estudantes devem ser realizadas na coletividade. Isso se dá quando aos indivíduos são proporcionadas situações que exijam o compartilhamento das ações na resolução de uma determinada situação que surge em certo contexto.

Portanto, se se pergunta de onde nascem, como se formam, de que modo se desenvolvem os processos superiores do pensamento infantil, devemos responder que surgem no processo de desenvolvimento social da criança, por meio do deslocamento a si mesma de formas de colaboração que a criança assimila durante a interação com o meio social que a rodeia. Vemos que as formas coletivas de colaboração precedem às formas individuais da conduta, que crescem sobre a base das mesmas e constituem suas progenitoras diretas e as fontes de sua origem (VYGOTSKI, 1997 p.219). 
Ao garantir que a atividade de estudo dos educandos se dê, prioritariamente, dentro de um coletivo busca-se concretizar o princípio ou lei de formação das funções psicológicas superiores elaborado pela teoria histórico-cultural.

\subsubsection{A atividade de estudo e as ações de aprendizagem}

Qualquer atividade que o homem se envolva, de um modo ou de outro, acarreta para si algum processo de aprendizagem. Ao realizar uma atividade concreta, o sujeito irá apropriarse em alguma medida dos conhecimentos existentes nessa atividade e dos modos que o homem desenvolveu para conhecer o mundo na atividade em questão. Esse processo de apropriação se faz necessário porque permite ao sujeito solucionar os problemas próprios da atividade em que está inserido (de jogo, de trabalho etc). Mas quando a atividade em questão é a atividade de estudo, esse processo geral de apropriação do conhecimento torna-se “o objetivo direto e o problema a ser resolvido por essa atividade” (RUBTSOV, 1996, p. 130). O central, portanto, deixa de ser o resultado concreto da resolução do problema para ser o próprio processo de apropriação do conhecimento; a própria aprendizagem.

$\mathrm{Na}$ atividade de estudo a resolução dos problemas está, portanto, menos ligada à obtenção dos resultados concretos do que a aquisição ou a aprendizagem de um modo geral de ação. Como já mencionamos, o modo geral de ação está vinculado aos conhecimentos teóricos e à formação do pensamento teórico nos educandos, constituindo-se em uma orientação para as ações do sujeito desde o início do processo de resolução de um problema. Tal orientação não é o mesmo que um guia, isto é, não propõe ou sugere a resposta do problema, mas aponta o modo como se deve chegar a essa resposta: de forma a considerar os conceitos historicamente elaborados pelos homens em uma situação similar. Assim, busca-se deslocar as ações dos educandos da solução concreta do problema (tarefa que ele se depara no seu dia-a-dia, nas diversas atividades de que toma parte) para os conceitos historicamente elaborados e relacionados ao problema em questão (tarefa própria da atividade de estudo).

Mas este “deslocamento” só ocorrerá se o modo geral de ação (conteúdo da atividade de estudo) for de fato o objeto real da consciência dos educandos, isto é, se ocupar o papel de objeto das ações de aprendizagem do sujeito. Conforme Leontiev “[...] um conteúdo 
realmente conscientizado é somente aquele que se manifesta diante do sujeito como objeto para o qual está diretamente dirigida a ação” (1983 p.203).

O modo geral de ação (os conceitos teóricos) deve ocupar, assim, o lugar de objetivo direto da ação do sujeito, relacionando-se ou coincidindo-se com o motivo da atividade. Em outras palavras, deve-se organizar o ensino de tal forma que nas soluções dos problemas propostos aos educandos aquele modo geral de ação ocupe em sua atividade o lugar estrutural de objetivo.

[...] inclusive os conhecimentos destinados à zona de desenvolvimento próximo dão o efeito de desenvolvimento (igual que o efeito de assimilação) só se os estudantes realizam as ações cognitivas adequadas ao conteúdo destes conhecimentos, ou seja, dirigidas ao esclarecimento de suas propriedades essenciais. Com isso, o processo de ensino não pode ser limitado só a comunicação entre o que ensina e o que estuda, a atividade dos alunos deve estar orientada ao mundo das coisas, sem as quais não se pode transmitir os conhecimentos que constituem o conteúdo do ensino (TALIZENA, 1988, p.34).

Os objetos e os fenômenos a serem conhecidos e operados pelo homem apresentam uma grande quantidade de características. Mas as características que efetivamente tomam parte da "imagem conceitual” que o sujeito faz do objeto ou do fenômeno não dependem tanto do objeto em si mesmo, mas fundamentalmente do tipo de relação que o sujeito estabelece com o referido objeto. Se essa relação pauta-se em uma atividade de estudo, em que o sujeito realizará suas ações orientado por um modo geral de ação, as características do objeto ressaltadas para ele não são aquelas propriedades comuns e externamente semelhantes do objeto, mas sim aquelas características essenciais do objeto e organizadas pelo educador: a sua gênese, o seu conceito. Ao estabelecer esse tipo de relação com o objeto, o sujeito pode efetivamente dar um salto no seu processo de desenvolvimento: ele irá adquirir novos modos de se relacionar com o mundo (novas ações), modos esses que serão conscientes para ele.

A atividade de estudo, assim, possui uma estrutura própria na qual, de acordo com Rubtsov (1996), encontramos dois elementos fundamentais: o problema de aprendizagem e as ações de aprendizagem. As ações de aprendizagem só podem ser compreendidas quando se referirem à resolução de um problema de aprendizagem, isto é, de um problema criado para que os educandos se apropriem do modo geral de ação para solucionar tal problema. Da mesma forma, um problema de aprendizagem só pode ser compreendido se as ações decorrentes dele se referirem a ações cujo objeto seja o próprio modo geral de ação. 
Mas como já apontamos anteriormente, o problema de aprendizagem, em si mesmo, não indica diretamente as ações de aprendizagem e as ações de ensino necessárias de serem realizadas pelos educandos e pelo educador. Para tanto, é preciso desenvolver o problema de aprendizagem em forma de uma situação desencadeadora de aprendizagem, que além de lidar com o problema e os conceitos teóricos advindos dele (a gênese ou a história do conceito), esboça as tarefas dos educandos e o plano de ação do educador.

Para organizar tais ações, para criar as tarefas de aprendizagem que os educandos deverão realizar, podemos nos apropriar da elaboração feita por Rubtsov (1996) a respeito da estrutura da ação de aprendizagem. Trata-se de uma proposição das etapas necessárias de serem percorridas pelos educandos para que o conhecimento teórico e o modo geral de ação sejam, de fato, objeto dos educandos em seus processos de resolução dos problemas propostos.

No quadro a seguir, reproduzimos na primeira coluna a estrutura da ação de aprendizagem proposta por Rubtsov (1996, p.133). A segunda e a terceira coluna sintetizam o nosso entendimento, a partir da estrutura geral das ações de aprendizagem propostas por Rubtsov, sobre as ações centrais dos educandos e dos educadores em uma atividade de ensino

\begin{tabular}{|c|c|c|}
\hline Estrutura da ação de aprendizagem & Ações dos educandos & Ações do educador \\
\hline $\begin{array}{l}\text { - transformação de um objeto ou de uma } \\
\text { situação, ressaltando as relações } \\
\text { fundamentais do sistema analisado. }\end{array}$ & $\begin{array}{l}\text { Análise do objeto da } \\
\text { aprendizagem, } \\
\text { explicitando os } \\
\text { elementos que julgam } \\
\text { ser essenciais; }\end{array}$ & $\begin{array}{l}\text { Desencadear a análise } \\
\text { inicial do objeto de } \\
\text { aprendizagem; } \\
\text { sintetizar as idéias sobre } \\
\text { os elementos essenciais } \\
\text { (abstrações); }\end{array}$ \\
\hline $\begin{array}{l}\text { - materialização da relação levantada } \\
\text { (objetos, desenhos, símbolos). }\end{array}$ & $\begin{array}{l}\text { Criar um modelo a partir } \\
\text { das abstrações ou operar } \\
\text { com modelos já criados; }\end{array}$ & $\begin{array}{l}\text { Disponibilizar modelos } \\
\text { com as abstrações e/ ou } \\
\text { coordenar o processo de } \\
\text { sua criação; }\end{array}$ \\
\hline $\begin{array}{l}\text { - transformação do modelo dessa relação a } \\
\text { fim de estudar as suas propriedades } \\
\text { intrínsecas. }\end{array}$ & $\begin{array}{l}\text { Análise do modelo, } \\
\text { operando com os seus } \\
\text { conceitos; }\end{array}$ & $\begin{array}{l}\text { Desencadear situações } \\
\text { em que os educandos } \\
\text { operem com os } \\
\text { conceitos sintetizados no } \\
\text { modelo; }\end{array}$ \\
\hline $\begin{array}{l}\text { - criação de problemas concretos e } \\
\text { práticos, que devem ser resolvidos } \\
\text { mediante a forma geral de ação. }\end{array}$ & $\begin{array}{l}\text { Planejar e concretizar a } \\
\text { resolução de um } \\
\text { problema concreto, } \\
\text { orientado pelos } \\
\text { conceitos estudados } \\
\text { (modo geral de ação); }\end{array}$ & $\begin{array}{l}\text { Criar um problema } \\
\text { concreto desencadeador } \\
\text { de aprendizagem e } \\
\text { coordenar o seu } \\
\text { processo de resolução } \\
\text { pelos educandos; }\end{array}$ \\
\hline - controle das ações realizadas & $\begin{array}{l}\text { Coordenar cada ação } \\
\text { com o modo geral de }\end{array}$ & $\begin{array}{l}\text { Coordenar o processo de } \\
\text { resolução orientada das }\end{array}$ \\
\hline
\end{tabular}




\begin{tabular}{|l|l|l|}
\hline & ação; & ações dos educandos; \\
\hline - avaliação da forma geral de ação, como & Avaliar o processo de & Organizar perguntas ou \\
resultado da resolução de um problema de & resolução do problema e & tarefas para que o \\
aprendizagem. & em que medida o modo & processo de resolução do \\
& geral de ação se & problema seja objeto de \\
& anćlise dos educandos \\
& resolução concreta & \\
\hline
\end{tabular}

Quadro 2: Ações dos educandos e ações dos educadores na atividade pedagógica (referenciado em RUBTSOV, 1996).

Para que as ações de aprendizagem ocorram e para que a própria atividade de aprendizagem se dê, é preciso que esses processos sejam conscientes e intencionalmente criados. Essa tarefa cabe ao educador, por meio de sua atividade de ensino. Assim, pensar nas ações dos educandos nos obriga a pensar nas ações dos educadores que irão criar e coordenar os estudantes em suas atividades de aprendizagem. Ao explicitarmos quais seriam as ações próprias dos educandos (ações de aprendizagem) e as ações próprias dos educadores (ações de ensino) estamos nos pautando na estrutura geral da atividade orientadora de ensino, que organiza as atividades e as ações de ambos.

Pensamos que as ações gerais dos educadores e dos educandos, apontadas por nós e desenvolvidas com base na estrutura geral proposta por Rubtsov, podem nos auxiliar, como educadores, na organização do trabalho educativo em geral, posto que serve, também, como um modo geral de ação para organizarmos o ensino. Da mesma forma, essa proposição pôde nos auxiliar (como pesquisadores) na elaboração de uma atividade orientadora de ensino (em forma de experimento didático) que objetivava contribuir para a formação do pensamento estético-artístico nos educandos. Entretanto, e pelo fato de representar as ações docentes e discentes de modo bastante sintetizado, essa proposta precisa ser ela mesma desenvolvida, tanto por uma maior explicitação dos princípios didáticos presentes na teoria históricocultural, quanto pelo seu desenvolvimento em situações reais de ensino.

\subsection{Princípios didáticos na psicologia histórico-cultural.}

Defendemos por diversas vezes neste trabalho que o ensino escolar busca formar nos educandos uma nova qualidade do pensamento (o pensamento teórico), o que implica na 
aprendizagem de ações generalizadas e generalizáveis durante o processo de solução dos problemas de aprendizagem propostos. Ao apropriarem-se dos conceitos teóricos, os educandos devem apropriar-se, simultaneamente, de modos gerais de ação referente à disciplina ou à área do conhecimento estudada, bem como de um modo geral de ação para a própria atividade de estudo.

Dessa forma, os estudantes saem do processo educativo não apenas com diversos conhecimentos e habilidades, mas também, e, sobretudo, com novas formas de conduta, novas formas de pensar/agir no mundo em que vivem, resultantes da formação do pensamento teórico.

Concretizar essa perspectiva de ensino implica tanto na adoção de bases teóricas que expliquem o processo de apropriação dos conhecimentos teóricos e de formação de novas condutas como processos que nos levam a uma outra qualidade do pensamento e, portanto, a novas possibilidades de ações no mundo, quanto na elaboração de um modo geral de ação docente, isto é, uma base teórico-metodológica capaz de efetivamente orientar a tarefa do educador no processo de organização do ensino.

Ambos os aspectos mencionados nos parecem estar presentes na teoria históricocultural. Entretanto, buscar nesta teoria princípios educativos que contribuam para pensarmos a educação (a função social da educação e modos efetivos de organização do ensino), pressupõe não só um estudo aprofundado dos conceitos desenvolvidos na perspectiva da teoria histórico-cultural, buscando neles articulações com as questões e necessidades pedagógicas, mas, principalmente, uma nova elaboração teórica a partir daqueles conceitos.

O objetivo central de nossa pesquisa nos remete diretamente a essa tarefa de elaboração de um modo geral de ação docente. Ao investigar o processo de organização do ensino para a formação do pensamento estético-artístico, podemos delinear não apenas um modo geral de ação para a educação física (e particularmente, para os conteúdos dessa disciplina relacionados às atividades artísticas), mas também um modo geral de ação docente para a formação do pensamento teórico.

Dizer isso não significa afirmar que estamos elaborando uma teoria do ensino. O modo geral de ação docente que propomos neste trabalho representa um elemento a mais no processo de elaboração de uma teoria do ensino a partir da psicologia histórico-cultural. Como tal, apóia-se tanto nos princípios educativos e didáticos presentes nessa teoria, quanto nas elaborações teóricas já desenvolvidas sobre a "atividade orientadora de ensino" (MOURA, 1996), que busca sintetizar, em si, um modo de organização do ensino a partir da teoria histórico-cultural. 
A despeito de ser uma teoria da ciência psicológica, podemos identificar, na teoria histórico-cultural, alguns princípios educativos gerais, tais quais: a) a concepção de homem como um sujeito histórico; b) a compreensão da formação social da consciência; c) a definição da educação como um processo de apropriação da experiência social da humanidade; d) a defesa do desenvolvimento do psiquismo como resultado da atividade prática humana, mediada pelos signos e instrumentos; e) o entendimento de que as funções psíquicas superiores são primeiro compartilhadas entre os sujeitos (interpsíquicas) e posteriormente internalizadas (intrapsíquicas); f) a defesa de que a apropriação dos conhecimentos é sempre uma atividade mediada por outras pessoas (colaboração dos mais experimentes).

Ainda que possamos reconhecer os potenciais práticos de tais princípios para a organização do ensino, eles não se constituem, em si mesmos, em princípios didáticos. Para isso, e para elaborarmos um modo geral de ação do trabalho educativo, precisamos realizar um movimento tanto de aprofundamento destes conceitos presentes na teoria históricocultural, quanto de novas elaborações teóricas que partam deles. O estudo dos princípios educativos e dos conceitos atrelados a eles elaborados, especialmente, por Vigotski, Davidov, Galperin e Leontiev, foram por nós sintetizados e transformados em três princípios didáticos da teoria histórico-cultural: a) princípio do ensino que desenvolve; b) princípio do caráter objetal da atividade; c) princípio da resolução de problemas de aprendizagem. ${ }^{33}$

Os princípios didáticos referem-se a posicionamentos sobre as relações entre ensino e aprendizagem e, derivados destes, fornecem orientações para se pensar a organização do ensino (estruturação do conteúdo, a organização e os métodos de ensino). Deste modo, os princípios didáticos advindos da psicologia histórico-cultural não se constituem em uma teoria do ensino propriamente dita, mas podem nos fornecer elementos para pensarmos a organização do ensino e para elaborarmos um modo generalizado do trabalho educativo. Nesse mesmo movimento pensamos estar o conceito de Atividade Orientadora de Ensino (originalmente elaborada por Moura, 1996) e da qual tratamos no tópico anterior deste trabalho.

\footnotetext{
${ }^{33}$ Para a organização destes princípios aqui expostos partimos da elaboração de outros autores que realizaram, também, uma síntese dos conceitos presentes na psicologia histórico-cultural em forma de princípios didáticos (NUNEZ, 2009; DAVIDOV, 1987). De toda forma, consideramos que se trata mais de um esboço dos princípios didáticos presentes na teoria histórico-cultural do que o seu desenvolvimento propriamente dito. Para desenvolver, de fato, estes princípios precisamos de um estudo e de um trabalho de análise que não cabe nesta dissertação.
} 
Analisaremos, a seguir, cada um dos três princípios didáticos mencionados por nós, procurando apontar como estes conceitos podem referenciar ou orientar os processos de organização do ensino no trabalho escolar.

\section{Princípio 1: do ensino que desenvolve e da zona de desenvolvimento próximo}

Ainda que se dê de forma não consciente ou explícita, a concepção de educação e de ensino depende diretamente da concepção de desenvolvimento e de aprendizagem que temos e, em especial, da relação estabelecida entre esses dois elementos. Em outros termos, a concepção de educação e de ensino depende do entendimento e do papel que damos ao meio social para os processos de desenvolvimento especificamente humanos.

O estudo teórico e prático do desenvolvimento infantil tropeça com uma de
suas maiores dificuldades quando se dá uma solução errônea ao problema do
meio e seu papel na dinâmica da idade, quando o entorno se considera como
algo externo em relação à criança, como uma circunstância do
desenvolvimento, como um conjunto de condições objetivas, independentes,
sem relação com ela, que pelo simples fato de sua existência influi sobre a
criança. Não se pode aplicar à teoria do desenvolvimento infantil a mesma
concepção do meio que se formou na biologia com relação à evolução das
espécies animais (VYGOTSKI, 1996, p.264).

Na teoria histórico-cultural o meio social, o meio formado por objetos e relações historicamente produzidos pelos homens, configura-se como o ponto de partida para todas as transformações por que passa o sujeito em seu processo de desenvolvimento. "A realidade social é a verdadeira fonte do desenvolvimento, a possibilidade de que o social se transforme em individual” (VYGOTSKI, 1996, p.264). Ainda que esta concepção assuma e incorpore os processos de desenvolvimento orgânicos, defende que os mesmos não são suficientes e nem nos remetem, diretamente, ao desenvolvimento das características culturais.

Imaginemos que uma criança nasça com determinadas características hereditárias relacionadas à audição, que lhe permita distinguir mais e melhor os sons. Essas características, ainda que constituam a base para a formação das capacidades humanas relacionadas à audição (como a música), não são, em si, capazes de determinar e nem sequer indicar as capacidades musicais que essa criança terá. As características biológicas do homem não se desenvolvem espontaneamente em características humanas. Desta forma, ainda que aquela criança imaginada por nós apresente extraordinárias bases biológicas relacionadas à audição, estas bases só podem tornar-se “capacidade musical” na medida em que a criança se aproprie das produções humanas relacionadas à música. Antes de o homem criar a música, 
antes da música ser um modo real do homem se relacionar com o mundo e com os demais, não havia na natureza humana a "capacidade musical” e foi somente criando a música que o homem criou e desenvolveu, em si mesmo, essa capacidade. Como disse Marx (2004, p.110) “[...] para o ouvido não musical a mais bela música não tem nenhum sentido”. Este é o sentido geral da afirmação de que o meio social cria o desenvolvimento dos indivíduos; de que ele seja a sua fonte.

Quais as implicações dessa concepção de desenvolvimento para os processos educativos em geral e para o escolar em específico? Uma delas é a compreensão do ensino como o elemento essencial e fundamental para o processo de desenvolvimento humano, particularmente para o desenvolvimento das funções psíquicas superiores (VYGOTSKI, 1995), dentre elas a formação do pensamento teórico.

Se a assimilação é a reprodução pela criança da experiência socialmente elaborada e o ensino é a forma de organização desta assimilação, dentro das condições históricas concretas, na sociedade dada, o desenvolvimento se caracteriza, antes de tudo, pelos avanços qualitativos no nível e na forma das capacidades, os tipos de atividade etc. de que se apropria o indivíduo (DAVIDOV; MÁRKOVA, 1987, p. 322).

O princípio do ensino que desenvolve (“enseñanza desarrollante”, DAVIDOV, 1988), pauta-se na idéia de que o desenvolvimento cultural do homem é um processo que se dá a partir da transmissão da experiência social entre os indivíduos, afirmando, assim, o papel do ensino no direcionamento e regulação dos ritmos e conteúdos do desenvolvimento em cada sujeito.

Este é, aliás, um dos princípios centrais da relação entre desenvolvimento e aprendizagem elaborado pela Psicologia Histórico-Cultural: o de que "o processo de desenvolvimento segue o da aprendizagem, que cria a área de desenvolvimento potencial” (VIGOTSKII, 1991, p.116). No princípio “do ensino que desenvolve” precisamos analisar três conceitos nucleares da teoria vigotskiana para pensarmos os processos de educação e ensino: o conceito de zona de desenvolvimento próximo e os conceitos de colaboração e imitação.

Nem todas as formas de aprendizagem pelas quais passamos resultam em desenvolvimento no sentido definido anteriormente (novas formas de conduta/ modos de ação ou novas estruturas das funções psíquicas superiores). E nem poderia ser assim. Pensando nas finalidades e nas formas de organização do ensino, podemos distinguir aqueles processos de aprendizagem que fornecem novas habilidades e conhecimentos, mas que se aproveitam de um desenvolvimento já existente e concluído no sujeito, daqueles processos de aprendizagem 
que contribuem para a elaboração de uma nova área ou etapa do seu desenvolvimento. Imaginemos que uma criança de nove anos esteja aprendendo a fazer um novo movimento (ex: uma rebatida com raquete). Esse processo de aprendizagem pelo qual a criança passa pode ou não ter significado para o seu processo de desenvolvimento em geral. Por um lado, a aprendizagem pode se restringir apenas a um aumento no seu repertório motor; por outro, pode significar um maior desenvolvimento de sua relação consciente com os movimentos (“movimento para-si”). Esta relação dependerá tanto do nível de desenvolvimento em que a criança se encontre, quanto da forma como o ensino foi organizado, ou seja, das tarefas de aprendizagem que foram propostas a ela.

Se a aprendizagem do novo movimento, para além de seus aspectos particulares, contribui para que a criança domine o processo de análise e síntese dos movimentos em geral, permitindo que ela se torne consciente do processo de aprendizagem daquele movimento específico que está realizando (verbalizando-o e abstraindo a idéia geral do movimento e formando uma imagem cognitiva consciente da ação motora), muito provavelmente o ensino terá significado para o processo de desenvolvimento geral desta criança, fornecendo a ela um modo geral de ação para a aprendizagem de outros movimentos. Se a aprendizagem desse mesmo movimento, contudo, não permitir esse grau de generalização para a criança, ou se por outro lado, ela já possui esse grau de generalização, a aprendizagem - possivelmente - terá um efeito apenas pontual: adquirir uma nova habilidade.

Assim, embora nem toda a aprendizagem resulte em desenvolvimento, todo desenvolvimento é resultado, necessariamente, da aprendizagem. Este princípio não nos autoriza a desconsiderar a existência de certos limites para a aprendizagem. É bem aceito o fato de que a criança precise alcançar determinados níveis de desenvolvimento para que a aprendizagem possa ser efetiva. Não há como refutar essa teoria, mas como aponta Vigotskii, o problema é pararmos nas contribuições que essa teoria nos deu.

\footnotetext{
Um ensino orientado até uma etapa de desenvolvimento já realizado é ineficaz do ponto de vista do desenvolvimento geral da criança, não é capaz de dirigir o processo de desenvolvimento, mas vai atrás dele. A teoria do âmbito de desenvolvimento potencial origina uma fórmula que contradiz exatamente a orientação tradicional: o único bom ensino é o que se adianta ao desenvolvimento (1991, p.114, grifo do autor).
}

No exemplo que demos anteriormente, se a criança já desenvolveu os mecanismos para a aprendizagem de novos movimentos, se é capaz de analisar um movimento, abstraindo as suas partes fundamentais, um ensino que se proponha a ensinar-lhe novos movimentos não 
cumprirá o papel de um ensino que desenvolve (no sentido de fornecer novos modos de ação e, portanto, novas possibilidades de intervenção do sujeito na realidade), por mais complexos que sejam os movimentos a serem aprendidos. Essa aprendizagem não resultaria em ganhos gerais para o desenvolvimento psíquico da criança, ainda que possa resultar em um maior ganho de habilidades motoras. Para esta criança o ensino não produziria desenvolvimento. $\mathrm{Ou}$ sob outro aspecto, essa criança necessitaria de outros tipos de aprendizagem para desenvolver$\mathrm{se}^{34}$.

[...] a característica essencial da aprendizagem é que engendra a área de desenvolvimento potencial, ou seja, que faz nascer, estimula e ativa na criança um grupo de processos internos de desenvolvimento no âmbito das inter-relações com outros, que, na continuação, são absorvidos pelo curso interior de desenvolvimento e se convertem em aquisições da criança.

Considerada deste ponto de vista, a aprendizagem não é, em si mesma, desenvolvimento, mas uma correta organização da aprendizagem da criança conduz ao desenvolvimento mental, ativa todo um grupo de processos de desenvolvimento, e esta ativação não poderia produzir-se sem a aprendizagem. Por isso, a aprendizagem é um momento intrinsecamente necessário e universal para que se desenvolvam na criança essas características humanas não-naturais, mas formadas historicamente. (VIGOTSKII, 1991, p. 115, grifos nosso).

Com base no fato de que o ensino se apóia tanto em funções e propriedades já desenvolvidas na criança, quanto naquelas ainda em desenvolvimento, tem-se a necessidade de estabelecer o "limite superior” de aprendizagem em relação ao desenvolvimento infantil. É neste contexto que o conceito de zona de desenvolvimento próximo (VYGOTSKI, 1996, VIGOTSKII, 1991, VIGOTSKI, 2009) foi elaborado.

O nível de desenvolvimento alcançado por uma criança em determinada etapa de sua vida só pode ser adequadamente estabelecido se soubermos o nível real de seu desenvolvimento - aquilo que já se desenvolveu plenamente, cujo ciclo finalizou - e a sua zona de desenvolvimento próxima, aqueles processos de desenvolvimento que ainda estão em andamento, que se encontram em formação.

As formas de conduta ou as funções psíquicas da criança que se encontram na zona de desenvolvimento próximo, não são, ainda, de domínio autônomo pela criança, ou seja, ela não as pode utilizar de forma consciente e deliberada. Contudo, podem lançar mão dessas formas de conduta ou das funções psíquicas desde que em colaboração com indivíduos mais experientes de sua sociedade. Aliás, é justamente mediante essa colaboração que a criança

${ }^{34}$ Provavelmente precisaria desenvolver formas de conduta atreladas às atividades da cultura corporal: pensamento estético-artístico, pensamento lúdico-estratégico e pensamento agonístico, conforme esboçado por nós no capítulo 1. 
pode se desenvolver, que as formas de conduta ainda não dominadas por ela podem ser desenvolvidas.

A zona de desenvolvimento próximo, portanto, representa a possibilidade máxima de aprendizagem em determinada etapa da vida da criança; representa o limite superior de seu desenvolvimento e, assim, a referência necessária para o processo educativo. É importante dizer que a aprendizagem que se dá na zona de desenvolvimento próximo, ao exigir uma forma de colaboração entre a criança e um indivíduo mais experiente, exige, também, a imitação por parte da criança (VYGOTSKI, 1996). A imitação deve ser, neste processo, necessariamente racional baseada na compreensão da operação intelectual que se imita (VYGOTSKI, 1996). Não cabe no conceito de zona de desenvolvimento próximo, o conceito de imitação mecânica. Portanto, a imitação se refere às operações intimamente relacionadas com a atividade racional da criança e que ocorre em colaboração com um adulto ou indivíduo mais experiente. Com base nesse processo, a função poderá ser internalizada, passando a fazer parte do nível de desenvolvimento real da criança.

A colaboração representa, assim, a relação dinâmica entre ensino-aprendizagemdesenvolvimento. Uma função que ainda esteja em desenvolvimento, ao ser mediada pelas tarefas de aprendizagem (forma genérica de colaboração e que pressupõe a presença direta ou indireta de pessoas mais experientes naquela tarefa), resultará numa função psicológica desenvolvida. Vigotski nos apresenta quatro formas de colaboração (VYGOTSKI, 1996, p. 269), todas elas servindo como um elo mediador para realização autônoma de uma determinada tarefa por parte da criança. Embora essas formas de colaboração não se constituam, em si e de forma acabada, num modo de organização do ensino, esboçamos na tabela abaixo (coluna da direita) possíveis orientações para a organização de um problema de aprendizagem.

\begin{tabular}{|c|c|}
\hline $\begin{array}{l}\text { Formas de colaboração (VYGOTSKI, } \\
\text { 1996) }\end{array}$ & Problema de aprendizagem: orientações \\
\hline $\begin{array}{l}\text { 1) Orientação de como resolver o } \\
\text { problema. }\end{array}$ & $\begin{array}{l}\text { - apoio em um esquema gráfico que } \\
\text { explicite a síntese da resolução do } \\
\text { problema, com os conceitos centrais para } \\
\text { resolver a tarefa e as relações entre esses } \\
\text { conceitos. }\end{array}$ \\
\hline 2) resolução do início do problema & $\begin{array}{l}\text { - professor indica uma forma de resolução } \\
\text { do problema (feita pelos estudantes ou } \\
\text { não) e que sirva de modelo para analisar } \\
\text { um aspecto de sua resolução. }\end{array}$ \\
\hline 3) resolução conjunta com uma criança & $\begin{array}{l}\text { - criança participa e colabora no processo } \\
\text { de resolução da tarefa com uma criança }\end{array}$ \\
\hline
\end{tabular}




\begin{tabular}{|c|c|}
\hline que já saiba resolver a tarefa & $\begin{array}{l}\text { que já saiba/domine os procedimentos e os } \\
\text { princípios para essa resolução; } \\
\text { - criança realiza um desenho/plano } \\
\text { sugerindo uma proposta de resposta } \\
\text { (solução do problema de aprendizagem). } \\
\text { Uma criança mais experiente } \\
\text { corrige/comenta a proposta dada. }\end{array}$ \\
\hline $\begin{array}{l}\text { 4) explicação dos princípios da solução } \\
\text { (perguntas orientadoras/fracionamento das } \\
\text { partes da tarefa). }\end{array}$ & $\begin{array}{l}\text { - princípio da solução do problema: } \\
\text { explicitação do modo geral de ação, via } \\
\text { orientação de cada ação das crianças no } \\
\text { processo de resolução da tarefa proposta. }\end{array}$ \\
\hline
\end{tabular}

Quadro 3: Formas de colaboração para os processos de desenvolvimento (referenciado em VYGOTSKI, 1996).

O conceito de zona de desenvolvimento próximo apresenta uma estreita relação com os processos de aprendizagem e educação e, por isso, precisa ser muito bem compreendido antes de se transformar num princípio pedagógico.

Se interpretarmos o conceito de zona de desenvolvimento próximo e, portanto, o conceito de colaboração mecanicamente, fazemos com que tais conceitos percam suas especificidades (pautada, sobretudo na concepção de desenvolvimento histórico do homem) e as possibilidades pedagógicas que apresentam.

Nem todas as atividades orientadas e direcionadas pelo adulto são atividades de colaboração no sentido elaborado por Vygotski (1996). A ajuda mecânica - específica ou pontual - a uma ação que a criança desempenha, a ajuda que se dirige à formação de novas habilidades ou conhecimentos (mais do que a novos modos de ação, novas formas de conduta), não se enquadra no conceito de colaboração e, portanto, não se aplica à zona de desenvolvimento próximo. Queremos dizer com isso que esse tipo de auxílio não está direcionado ao processo de desenvolvimento da criança, ou seja, à formação de novas funções ou novas formas de conduta. Trata-se de uma aprendizagem que não desenvolve o sujeito, mas que, ao contrário, se apóia em processos de desenvolvimento já realizados.

Esta diferenciação é importante quando pensamos na implicação do conceito de zona de desenvolvimento próximo para o trabalho pedagógico. $\mathrm{O}$ auxílio do educador que incide prioritariamente (ou intencionalmente) sobre os resultados das soluções de uma tarefa em particular, ou sobre as habilidades que aquela tarefa requer, não é uma forma de colaboração; não representa um processo educativo organizado para o desenvolvimento de funções ou formas de conduta ainda inexistentes no educando. Trata-se, especificamente, de um auxílio 
didático. Não estamos afirmando, com isso, que essa forma de intervenção do educador seja indesejável ou mesmo desnecessária; ao contrário, trata-se de uma ação do trabalho pedagógico absolutamente imprescindível. Entretanto, é preciso ter claro que essa forma de intervenção, a despeito de todos os seus méritos e importância para a criança, não é organizada e orientada para o desenvolvimento cultural do sujeito e, na verdade, nem lhe cabe esta função.

A confusão ou indistinção entre essas duas formas de intervenção ou auxílio pode resultar num abandono, na pratica pedagógica, da organização do desenvolvimento das funções psíquicas superiores e das formas culturais de conduta. Se quero contribuir para que os educandos adquiram um novo modo de ação, modo esse que representa uma forma de consciência social, historicamente elaborada, em determinada atividade humana, preciso organizar o ensino (as ações de ensino e as ações de aprendizagem) para que esse modo de ação generalizado seja, de fato, o objeto de estudo dos educandos; o objeto de suas consciências.

Em outros termos, se o modo geral de ação (como síntese de uma forma cultural de conduta, uma forma do homem se relacionar com o mundo, com os outros e consigo mesmo) não aparece para o educador como ponto de partida do ensino, como o seu objeto de trabalho, dificilmente os educandos irão se apropriar desse modo geral de ação, a não ser de forma espontânea.

Assim, para cada disciplina e para cada conteúdo dessa disciplina, é preciso elaborar aqueles conhecimentos (e aquelas aprendizagens) que podem, de fato, contribuir para o desenvolvimento dos educandos. Isso não significa priorizar ou absolutizar essas aprendizagens no interior do trabalho pedagógico, mas de torná-las processos conscientes na dinâmica de organização do ensino.

Em síntese, podemos resumir as discussões realizadas sobre o "princípio do ensino que desenvolve” nos seguintes tópicos:

a) O ensino deve organizar e direcionar o conteúdo e os ritmos de desenvolvimento dos sujeitos, tendo por referência a formação das funções psicológicas superiores. Deve contribuir para fazer surgir modos de ação ainda não existentes no sujeito, que lhes permitam enxergar a realidade de outra maneira (a realidade em sua essência) e, assim, intervir nessa realidade com uma outra qualidade.

b) Nem todo ensino e nem toda aprendizagem devem cumprir esse papel. Em termos quantitativos, haverá muito mais aprendizagens de habilidades e conhecimentos específicos, 
que cumprem a função de aumentar o repertório da criança, do que aprendizagens de novos modos de ação (novas condutas). Mas estas devem ser cuidadosamente elaboradas e organizadas no interior da prática pedagógica, porque elas, de certo modo, orientam os ritmos e as qualidades das demais aprendizagens.

c) A aprendizagem não cumprirá a sua função para o desenvolvimento em duas circunstâncias: quando o sujeito já alcançou esse desenvolvimento - portanto requer desenvolver outros aspectos - e quando o desenvolvimento requerido está muito além de suas capacidades, mesmo considerando o auxilio de pessoas mais experientes. Nesses dois casos, o ensino é considerado (do ponto de vista do desenvolvimento) ineficaz.

Princípio 2: do caráter objetal da atividade de estudo e do processo de internalização das funções psíquicas superiores.

A característica básica de qualquer atividade é seu caráter objetal (LEONTIEV, 1978). Qualquer atividade possui um objeto (material ou não material) que dirige a ação do sujeito, ou que o motiva para a ação. Deste modo, os processos de conhecimento do mundo, implicam, sempre, em um processo de ação do sujeito nesse mundo. Apropriar-se de um conceito é apropriar-se de uma atividade historicamente elaborada e que deu origem àquele conceito e implica que o sujeito forme em si novas formas de conduta, novas formas de estar no mundo e de nele se relacionar.

[...] o caráter real dos conhecimentos não consiste nas abstrações verbais, mas sim nos procedimentos de atividade do sujeito cognoscente, para quem a transformação dos objetos, a fixação dos meios de tais transformações constituem um componente tão indispensável dos conhecimentos como sua cobertura verbal. (DAVIDOV, 1987 p. 148).

Este posicionamento, embora ratifique o caráter ativo da aprendizagem, não significa a defesa de um "ativismo" no ensino, ou seja, a defesa de ações com os objetos, em si mesmos. Isto resultaria numa valorização daqueles conhecimentos adquiridos pelo próprio sujeito, em sua atividade de exploração do mundo, em detrimento daqules conhecimentos que lhe são fornecidos, direta ou indiretamente, por outros indivíduos. Como diz Nunez (2009, p.61) "Sendo o ensino um processo social e intencional, não é necessário que a criança descubra de novo por si só apenas, as características essenciais para definir o conceito”. 
A defesa do caráter ativo do processo de aprendizagem significa, no interior da teoria histórico-cultural, não só a defesa do sujeito que faz, que manipula objetos, mas eminentemente a defesa de um sujeito em atividade. E no caso da escola, esses sujeitos devem estar em atividade de estudo.

Assim, pois, o conteúdo principal da atividade de estudo é a assimilação dos
procedimentos generalizados de ação na esfera dos conceitos científicos e as
transformações qualitativas no desenvolvimento psíquico da criança, que
ocorrem sobre esta base (DAVIDOV; MÁRKOVA, 1987, p. 324).

Cumpre papel importante e fundamental nesse processo de organização da atividade de estudo dos educandos, a identificação das ações específicas que os estudantes devem realizar com o objeto de estudo de modo que, ao fazê-las, possam revelar o conteúdo do conceito estudado.

Um objeto só se constituirá como objeto de estudo, propriamente dito, quando suas características essenciais forem reveladas e explicitadas para os educandos, de modo que tais características se configurem como uma orientação para suas ações. A ação do estudante com um objeto de estudo não pode ser qualquer ação, mas sim ações orientadas por aqueles atributos essenciais do objeto - orientação essa fornecida pelo educador - e que revelem os conceitos ou conteúdos de aprendizagem.

Neste sentido, os materiais empíricos (ou os objetos assimilados por suas características aparentes e evidentes) devem ser transformados pela atividade do educador em materiais de estudo (objeto de estudo), que passam a explicitar o conteúdo a ser aprendido e, juntamente com ele, explicitam o modo geral de ação, ou seja, a orientação para realização das tarefas de estudo e das ações de aprendizagem.

Quando o objeto empírico é identificado automaticamente com o objeto de estudo, dificilmente os educandos, ou a maioria deles, podem adquirir um modo de ação generalizado a partir daquele objeto. Nestes casos, as ações dos educandos partem do concreto empírico e chegam a algumas abstrações gerais, por via da comparação entre diferentes objetos empíricos. Para que o ensino cumpra a sua função de ir do abstrato ao concreto (DAVYDOV, 1982; KOPNIN, 1978) o objeto empírico precisa ser, ele mesmo, transformado para que os estudantes se relacionem não com o objeto em si, com suas características sensorialmente evidentes, mas com as relações essenciais presentes em tal objeto e com seus próprios processos intelectuais de abstração e generalização. 
Como vemos, se o princípio do caráter visual dita, na educação, a passagem do 'particular ao geral', o princípio do caráter objetal fixa a possibilidade e a conveniência de que os alunos descubram o conteúdo geral de um certo conceito como base para a ulterior identificação de suas manifestações particulares (DAVIDOV, 1987, p.152).

Assim, embora a atividade de estudo pressuponha a existência de um objeto de estudo e de ações reais com esse objeto, o ciclo do processo de aprendizagem para um novo conceito implica na transformação paulatina daquele objeto e das ações com aquele objeto, que vão se transformando de ações materiais para ações mentais (GALPERIN, 1987; GALPERIN et al, 1987; NUNEZ, 2009).

Essa proposta para a organização do ensino desenvolvida por Galperin (1987), deu-se por meio do conceito de "base orientadora da ação", em que é proposto um modelo explicativo e organizativo do ensino, que concretize a idéia de internalização dos conhecimentos elaborada por Vigotski $(1993,1995)$.

De acordo com este autor, todo conhecimento é o reflexo de um modo de ação real (relações) entre as pessoas. Para aprender um novo conhecimento (conceito), o individuo primeiro vivencia esse conceito compartilhando-o com outras pessoas e posteriormente aplica-o a si mesmo.

Podemos formular a lei fundamental deste desenvolvimento do seguinte modo: todas as funções psicointelectuais superiores aparecem duas vezes no decurso do desenvolvimento da criança: a primeira vez, nas atividades coletivas, nas atividades sociais, ou seja, como funções interpsíquicas: a segunda, nas atividades individuais, como propriedades internas do pensamento da criança, ou seja, como funções intrapsíquicas. (VIGOTSKII, 1991 p. 114).

Sintetizando as discussões sobre o "princípio do caráter objetal da atividade de estudo”, podemos dizer o seguinte:

a) Qualquer atividade de estudo pressupõe a existência de um objeto de estudo (a princípio material e posteriormente não material) e de ações a serem realizadas com tal objeto.

b) Um objeto de estudo busca desenvolver nos educandos um determinado modo de ação generalizado na atividade que se está estudando, modo esse que sintetiza as ações dos homens no processo de resolução de problemas naquela atividade. Para tanto, o estudante deve, desde o início, relacionar-se com o referido objeto como um objeto que carrega as 
características essenciais e gerais daquele modo de ação, isto é, como um objeto genérico e não como um objeto particular.

c) O objeto de estudo irá orientar as ações de estudo dos educandos, permitindo que eles se apropriem dos conteúdos e conceitos da disciplina ou da atividade a que ela se refere. Neste sentido, a elaboração de materiais didáticos, ou a organização destes dentro de atividades de estudo, configura-se como um importante momento do processo de organização do ensino.

\section{Princípio 3: da resolução de problemas de aprendizagem}

O conhecimento a ser formado na escola (conhecimento teórico) precisa ser formado por meio da apropriação de um modo geral de ação. Neste sentido, o educador precisa revelar os conceitos essenciais do objeto de estudo, as relações essenciais presentes nele, para que essas se constituam no objeto de aprendizagem dos estudantes. Esse princípio tem por base o próprio processo de conhecimento postulado no materialismo histórico-dialético: a ascensão do abstrato ao concreto (DAVYDOV, 1982; KOPNIN, 1978).

Determinar o objeto de estudo, nos termos referidos anteriormente, remete-nos à explicitação da unidade fundamental do objeto ou do fenômeno a ser aprendido. Para cada disciplina e para cada atividade de ensino é preciso revelar o seu verdadeiro conteúdo, os seus conceitos teóricos, a sua unidade fundamental e as abstrações iniciais com as quais operarão os educandos. Qual/quais os conhecimentos fundamentais de serem aprendidos naquela disciplina e para aquele conteúdo? Isso depende, além da natureza do conteúdo (da disciplina), dos objetivos de ensino que se tenha. $O$ que quero que meus educandos desenvolvam com esse conteúdo, quais novos conhecimentos quero lhes propiciar?

Considerando que a atividade de estudo tem como finalidade central a transformação do próprio sujeito em atividade, mais do que a transformação das coisas com as quais este sujeito atua (DAVIDOV, 1987) as ações de aprendizagem a serem realizadas com o objeto de estudo têm função mais de permitir que os educandos se conscientizem do modo de ação para resolver a tarefa (bem como de seus processos de abstrações e sínteses teóricas) do que a obtenção de um determinado resultado prático com o objeto.

Em outras palavras, na atividade de estudo, importa levantar problemas de aprendizagem que contribuam para o desenvolvimento de novas condutas, novas atividades nos educandos e que explicitem para ele a origem do conceito estudado. O ensino, portanto, deve se dar a partir da análise das condições da origem do conhecimento a ser estudado. 
Com relação à “origem do conhecimento”, cremos que seja possível trabalharmos com duas dimensões dessa origem. A primeira dimensão seria a “filogenética”, uma origem histórica do conhecimento, no sentido de história da humanidade, isto é, do processo de desenvolvimento daquele conhecimento a partir das condições ou problemas iniciais que surgiram para a humanidade e cujas soluções levaram os homens ao desenvolvimento de determinados conceitos. Este seria o caso do conceito de números, a partir da necessidade da humanidade de controlar as quantidades (ex: número de ovelhas presentes na tribo). A segunda dimensão da origem do conhecimento seria "ontogenética”, uma origem histórica, também, mas histórica no sentido das condições existentes hoje que ainda exigem um determinado conceito e que nos permitem analisar o próprio conceito. Este seria o caso do conceito de número a partir de situações emergentes do cotidiano (MOURA, 1996), como o controle de figurinhas para bater "bafo" com os amigos.

O que determinará se uma situação emergente do cotidiano permitirá a apropriação do conceito pela criança é a tarefa de aprendizagem proposta e organizada pelo educador. Para ficarmos no mesmo exemplo, o problema de controlar as figurinhas que tem constitui-se num problema real e imediato para a criança. Seu interesse em resolver o problema é de ordem prática; ela quer a solução: quanto tenho, quanto preciso, quanto perdi. A situação, para o educador, constitui-se em uma situação potencial de aprendizagem, ou seja, em uma possibilidade de reorganizar o problema que a criança já se coloca de modo a transformá-lo em um problema de aprendizagem, em que o central seja ela se apropriar de um modo geral de ação de controle das quantidades. Neste caso, controlar as figurinhas passa a ser um caso específico do controle de quantidades em geral. A criança, orientada pelo educador que busca criar nela a necessidade do conhecimento teórico, parte do modo geral de solução do problema para posteriormente resolver problemas específicos em que esse modo de ação caiba.

Sintetizando as discussões sobre o "princípio da resolução de problemas de aprendizagem” podemos dizer o seguinte:

a) Um problema de aprendizagem, ainda que sempre parta de uma situação real, de um problema realmente existente na humanidade, elabora esse problema de modo a evidenciar o aspecto genérico presente nele, isto é, de modo a evidenciar os conceitos teóricos elaborados a partir dele. 
b) A solução de um problema de aprendizagem constitui-se mais na explicitação de um modo geral de ação por parte do educando e, portanto, na apropriação de um conceito pelo estudante, do que na resolução concreta do problema, ainda que essa resolução sempre se dê. Em outras palavras, a resolução concreta de um problema deve ser considerada como um caso particular da resolução geral do problema, isto é, do modo geral de ação para resolver aqueles tipos de problemas. 


\section{CAMINHOS METODOLÓGICOS: AS AÇÕES DO PESQUISADOR}

Nossa pesquisa, que tem por objetivo central investigar o processo de organização do ensino para a formação do pensamento estético-artístico, foi realizada a partir de uma pesquisa teórica sobre a temática da arte, da atividade humana e da organização do ensino, (pesquisa essa referenciada no materialismo histórico-dialético e, mais especificamente, na teoria histórico-cultural) e de uma pesquisa experimental que pretendeu acompanhar esse processo de organização do ensino para a formação do pensamento teórico, focando, em especial, nas ações docentes realizadas e/ou necessárias de serem realizadas. O experimento didático foi realizado com uma unidade didática sobre o circo, elaborado por nós e objeto também de nossas análises, com crianças do $4^{\circ}$ ano do ensino fundamental I.

A realização de uma pesquisa experimental, como parte da investigação geral da pesquisa, o trabalho com os dados coletados (seja por nós mesmos ou por outras pessoas), exige a explicitação da relação que estabelecemos e pretendemos estabelecer entre esses dados e os dados referentes à pesquisa bibliográfica. Como as pesquisas teóricas feitas previamente à pesquisa empírica se articulam no processo de organização do experimento e no processo de análise dos dados experimentais? Como, por sua vez, os dados experimentais analisados se articulam com as pesquisas teóricas anteriormente feitas?

Estamos às voltas aqui, sobretudo, com duas classes de problemas: a da organização da pesquisa propriamente diante e a da exposição da pesquisa.

Em nosso trabalho, a maior parte dos capítulos teóricos foram escritos antes da própria organização do experimento didático. Isto é, a aproximação de nosso objeto de pesquisa deuse, primeiramente, através de um estudo teórico-conceitual sobre a atividade artística, o pensamento teórico, a formação de conceitos, a atividade criadora e a atividade de ensino e de aprendizagem. Este movimento fez com que tais referenciais teóricos servissem de base para a organização de nosso experimento didático (para a organização da pesquisa empírica, propriamente dita) e para a realização da própria análise dos dados obtidos.

Nesse momento, então, tivemos um movimento de contribuição da pesquisa teórica para a pesquisa experimental, através, sobretudo, de alguns princípios para a organização do ensino e para a análise dos dados.

Passaremos agora a uma breve exposição da organização de nosso experimento didático para, depois, apresentarmos o processo de organização de nossos dados 
experimentais, o modo como fomos organizando estes dados e a análise propriamente dita, (realizada no capítulo 6).

\subsection{O processo de organização do experimento didático.}

Pretendíamos com a nossa pesquisa investigar o processo de organização do ensino relacionado à formação do pensamento estético-artístico, isto é, à formação do pensamento teórico no campo da arte. Se por um lado, era importante acompanharmos o processo de desenvolvimento deste tipo de pensamento nos sujeitos, como ia se dando a sua apropriação dos conceitos e as suas relações com a atividade criadora, nosso foco de investigação residia mais nos processos de ensino e organização do ensino do que nos processos de desenvolvimento psíquico propriamente dito. Ainda que haja uma relação bastante próxima entre os processos de ensino e desenvolvimento (o ensino, como afirma a teoria vigotskiana, é o aspecto fundamental e necessário para o desenvolvimento cultural do sujeito), nossa investigação não é uma investigação psicológica, mas sim pedagógica.

Podemos pensar que há uma linha tênue entre essas duas áreas de investigação, sobretudo quando se dão dentro de uma mesma perspectiva teórica (a teoria históricocultural). Entretanto, ainda que seja tênue, pensamos que efetivamente exista. A forma como organizamos a pesquisa, os objetivos propostos e o modo como organizamos a análise dos dados, apontam mais para uma pesquisa de cunho pedagógico, que busca investigar as relações e os processos de organização do ensino, o processo de apropriação da atividade teórica pelos educandos - ou as “leis” da organização do ensino - do que uma pesquisa de cunho psicológico, que busca investigar os processos de desenvolvimento de uma ou outra função psíquica - as leis do desenvolvimento. Em um caso, o produto da pesquisa refere-se mais à organização do ensino e no outro, mais aos processos de formação psicológica. Utilizando-nos dos termos leontievanos, o objeto de consciência do pesquisador, no primeiro caso, é a organização do ensino e as possibilidades deste para potencializar os processos de aprendizagem e desenvolvimento dos estudantes. No segundo caso, o objeto de consciência do pesquisador são os processos de formação e desenvolvimento de uma determinada função psicológica, ainda que ele teça considerações sobre a organização do ensino.

Em nossa pesquisa, por exemplo, esboçamos análises do movimento conceitual por que passaram nossos estudantes, bem como do movimento de apropriação da atividade 
criadora. Mas tais análises não nos remetem a uma investigação do processo mesmo de desenvolvimento da imaginação ou da formação de conceitos. Ao contrário, nos apoiamos em pesquisas que investigaram esses processos, sendo que nossas análises servem como meio para pensarmos e elaborarmos considerações sobre o processo de organização do ensino.

A partir dessas discussões, pensamos que nossa investigação experimental possui fortes vínculos com o método investigativo proposto pela psicologia histórico-cultural, que tem por base a compreensão de que os processos psíquicos historicamente surgidos na humanidade (como o pensamento teórico) só podem ser desenvolvidos mediante a aprendizagem dessas funções.

O método genético experimental (VYGOTSKI, 1995) e, mais especificamente, a metodologia do experimento formativo (DAVIDOV, 1988) buscam superar uma investigação no campo da psicologia apenas constatadora dos processos de desenvolvimento, concretizando uma pesquisa que considere que tais processos só podem surgir mediante o ensino e a aprendizagem dos mesmos. O experimento formativo, então, busca investigar o processo de desenvolvimento de determinadas funções psíquicas que são intencionalmente formadas durante o próprio processo da investigação.

Para o método do experimento formativo é característico a intervenção ativa do investigador nos processos psíquicos que ele estuda. [...] Para nós, se pode chamar ao experimento formativo experimento genético modelador, o que traduz a unidade entre a investigação do desenvolvimento psíquico das crianças e sua educação e ensino (DAVIDOV, 1988 p.196, grifos do autor).

Entretanto, e como já discutimos, nossa investigação não é uma investigação propriamente psicológica. Assim, ainda que compartilhemos do mesmo método geral de investigação (o método materialista histórico e dialético), nossa metodologia deveria ser, necessariamente, outra. Estamos chamando de experimento didático à metodologia de investigação de nossa pesquisa.

Com o nosso experimento, buscávamos formar um determinado tipo de relação do sujeito com a realidade, formar um determinado tipo de pensamento: o pensamento estéticoartístico. Da mesma forma que o experimento formativo, nossa pesquisa foi uma forma de propiciar o desenvolvimento dos sujeitos. Entretanto, e como já mencionamos, por termos como objeto de nosso trabalho mais a organização do ensino do que a formação psicológica dos estudantes, a situação experimental enfatizou uma investigação da relação ensino/aprendizagem em detrimento de uma investigação da relação entre o 
ensino/desenvolvimento. Pensamos que muitas situações propostas durante o nosso experimento não foram e não poderiam ser analisadas de um ponto de vista do desenvolvimento das crianças, ainda que possamos esboçar o processo de organização do ensino para o desenvolvimento do pensamento estético-artístico a partir de nossos dados. Resumindo, a nossa metodologia estava subordinada ao objeto de nossa pesquisa, que é o processo de organização do ensino para a formação do pensamento teórico.

Ainda que seja uma situação realmente de ensino, o experimento didático possui uma condição que o faz ser uma situação de ensino especial, comparativamente às situações de ensino que ocorrem nas escolas. O experimento didático cria uma situação de ensino especialmente organizada para os fins da pesquisa. Ainda que mantenha, em si, vinculações com a escola e com a sociedade em geral, o experimento didático responde, em primeiro lugar, à necessidade da pesquisa e não à necessidade de ensino presente na situação escolar. De novo, encontramos aqui, também, uma linha bastante tênue entre uma situação e outra, mas o que não quer dizer uma linha contínua entre as duas. Se na situação de ensino escolar, o objeto da consciência do educador é a organização do ensino e a aprendizagem das crianças, o objeto da consciência do investigador, numa situação de experimento didático, é o próprio objetivo da pesquisa. Muitas vezes, e como no nosso caso, o objetivo da pesquisa inclui, em si, os objetivos anteriormente mencionados e que estão presentes, em primeiro plano, no educador na escola. Mas no caso do experimento didático o pesquisador organiza o ensino e a atividade de aprendizagem dos estudantes “menos" para ensinar e para que as crianças aprendam, e mais, ou fundamentalmente, para poder pensar e investigar a própria organização do ensino proposta e os modos de realização das atividades de aprendizagem.

A organização da atividade de ensino, o planejamento do ensino a partir dos princípios didáticos da teoria histórico-cultural foi, nesta pesquisa, objeto de estudo e análise. Assim, não iremos descrever, tampouco analisar, neste momento, o planejamento elaborado. Faremos apenas algumas considerações mais gerais sobre o experimento didático (as condições de sua organização e efetivação), deixando as discussões do plano de ensino e das ações dos educadores para o capítulo da análise dos dados (capítulo 6).

\section{- o local do experimento didático}

Nosso experimento didático foi desenvolvido em um projeto existente na Faculdade de Educação da Universidade de São Paulo (FEUSP) chamado Clube de Matemática. O Clube de Matemática é uma atividade especialmente organizada para a aprendizagem das crianças e 
dos professores-estagiários (estudantes de pedagogia ou de matemática, futuros professores). A idéia de realizarmos nosso experimento didático em um espaço construído, prioritariamente, para a aprendizagem da matemática deu-se por duas razões centrais.

Em primeiro lugar, queríamos realizar o nosso experimento em condições de ensino tais que permitissem ou potencializassem os nossos objetivos de pesquisa. A estrutura do Clube de Matemática, com grupos de no máximo dezesseis crianças e com uma média de três estagiários-professores por grupo, apontava-nos não apenas para uma excelente condição de pesquisa, quanto para uma condição desejada de ensino.

Com relação ao ensino, ter menos crianças em um mesmo agrupamento para realizar uma atividade de estudo propicia maiores possibilidades de intervenções e mediações do educador. Além disso, o fato dos educadores poderem trabalhar em uma situação coletiva (trabalharem efetivamente juntos uns com os outros) propicia uma maior qualidade no próprio processo de ensino e aprendizagem, por organizá-lo como um processo, de fato, coletivo; como uma síntese de um trabalho de todos.

Com relação à pesquisa, além de termos um agrupamento menor de crianças (o que nos permitiria olhar para cada uma delas e para os seus processos de aprendizagem), tínhamos os educadores-estagiários que, assumindo a atividade de ensino, nos permitia uma maior liberdade de ações durante a pesquisa (e como pesquisadores), ainda que assumíssemos, muitas vezes, a função de educador durante o experimento, intervindo diretamente nas ações dos estudantes.

Em segundo lugar, o Clube de Matemática foi escolhido como local de nossa pesquisa pela proposta de ensino e aprendizagem que possui. O clube busca se constituir como um espaço de aprendizagem onde o ensino seja maximamente significativo para as crianças e maximamente planejado pelos educadores-estagiários. Os dezesseis encontros, semanais, realizados durante um semestre (tempo de duração do Clube) são divididos de um modo tal que contemple diversos momentos para a reorganização e planejamento das atividades de ensino, bem como para a socialização e avaliações coletivas das atividades que estão sendo realizadas em cada grupo. Essa organização nos parece potencializar o movimento de conscientização da atividade de ensino por parte dos educadores-estagiários: seu papel, objetivo e possibilidades de ações.

Antes e depois de cada módulo de aulas (composto por três aulas) os professores estagiários reúnem-se juntamente com o professor coordenador do Clube de Matemática ${ }^{35}$

\footnotetext{
${ }^{35}$ Prof Doutor Manoel Oriosvaldo de Moura
} 
para avaliarem o módulo ministrado e planejarem o módulo seguinte. Assim, dos dezesseis encontros totais dos professores-estagiários, pelo menos cinco constituem-se em avaliações e planejamentos. Nos dias de aula, são reservados ao menos 50 minutos para as avaliações coletivas do dia de trabalho.

- os sujeitos do experimento didático.

O experimento didático foi realizado com um grupo de estudantes que cursavam o $4^{\circ}$ ano do ensino fundamental I. Esse $4^{\circ}$ ano estava já inserido no Ensino Fundamental de 9 anos e, assim, corresponderia a $3^{\text {a }}$ série do Ensino Fundamental de 8 anos.

Catorze crianças participaram das atividades didáticas com o circo, sendo onze meninos e três meninas, todos sorteados para participarem do Clube de Matemática. Esse grupo de estudantes foi acompanhado por três estudantes-estagiários (dois deles cursando o $3^{\circ}$ ano do curso de pedagogia e um deles cursando o último semestre desse curso) e mais dois pesquisadores (um de Mestrado e outro de Doutorado) que realizavam suas investigações a partir do experimento didático elaborado por nós.

- algumas considerações sobre o experimento didático.

Trabalhamos em nosso experimento didático com três frentes de planejamento: um planejamento geral (plano I) que procurou explicitar as máximas ou melhores condições de ensino para os fins de nossa pesquisa; um planejamento geral (plano II) adaptado às condições que teríamos (condições essas relacionadas, especialmente, ao tempo de ensino, posto que as atividades de ensino relacionadas à apropriação do pensamento estético-artístico seriam compartilhadas com atividades de ensino que visassem à formação do pensamento matemático das crianças); e um planejamento específico para cada encontro/aula (planos de aula).

O planejamento geral (I e II) buscou elaborar e/ou explicitar o conceito nuclear para o ensino-aprendizagem da atividade circense e os conceitos específicos relacionados à criação de uma cena circense (os elementos de criação). Além dos conceitos, nucleares e específicos, elaboramos nos planejamentos gerais um esboço de cada uma das aulas, elencando os conceitos que deveriam ser trabalhados e as tarefas de estudo que deveriam ser propostas às crianças para a apropriação dos conceitos. Por fim, elaborávamos para cada aula, um 
planejamento mais específico, discutido entre todos os educadores ${ }^{36}$, em que explicitávamos: o objetivo do ensino, os conceitos a serem trabalhados, as ações de aprendizagem propostas e os materiais necessários para aquela aula.

Os planejamentos foram elaborados de acordo com três princípios de organização do ensino, que serão discutidos quando analisarmos os próprios planejamentos. São eles: a) propor problemas de aprendizagem previamente aos problemas concreto-práticos no processo de apropriação dos conceitos teóricos; b) propor atividades permanentes de análise e síntese das cenas, mediadas pelos conceitos teóricos trabalhados (elementos de criação); c) elaborar o planejamento de acordo com a estrutura da Atividade Orientadora de Ensino.

\subsection{0 processo de organização da análise dos dados.}

\subsubsection{As unidades conceituais de análise.}

O processo de organização dos dados da pesquisa - que já se constitui em uma forma de direcionarmos a análise - e o processo de análise propriamente dita, iniciou-se com uma aproximação mais geral dos dados a partir dos registros escritos durante as dez aulas de nosso experimento didático ${ }^{37}$. Buscávamos, nesse momento, identificar algumas linhas, algumas questões, que nos permitissem visualizar o conjunto de dados obtidos (e não um ou outro dado específico), articulando-os com os objetivos de nossa pesquisa. Este primeiro olhar para os dados nos permitiu identificar algumas questões que julgávamos serem possíveis e necessárias de discutirmos, o que nos levou a elaboração de uma primeira forma de organização desses dados. Neste momento, algumas questões levantadas já nos apontavam para discussões bastante genéricas ou para alguns “núcleos” possíveis para nossas análises.

Era um momento de esboçar os conceitos centrais que poderiam nos ajudar a compreender a realidade investigada por nós. Buscávamos eleger os conceitos teóricos mais gerais e que pudessem assumir um papel mais direto de instrumento para as análises, o que nos levou a elaboração de "unidades conceituais de análise”, isto é, conceitos capazes de

\footnotetext{
${ }^{36}$ Os planos gerais não foram elaborados coletivamente pelos educadores, embora tenham sido discutidos entre todos para a elaboração dos planos de aula.

${ }^{37}$ A maior parte dos registros foram feitos após as aulas com as crianças (e no mesmo dia de sua realização), posto que durante as aulas, geralmente, desempenhávamos o papel de educadores, atuando de forma direta com as crianças.
} 
expressar a totalidade de um determinado conjunto de dados e, assim, auxiliar no processo de explicação desses dados.

As unidades conceituais de análise, que surgiram do diálogo com as unidades de análise de Vigotski (2009) são, em uma pesquisa, aqueles conceitos nucleares e mediadores que referenciam, do início ao fim, as ações de análise do pesquisador e que nos permitem apreender o objeto da investigação em sua totalidade. As unidades conceituais de análise, de certo modo, contribuem para que apreendamos a essência de um conjunto de dados, a unidade que a caracteriza. Na mesma medida em que os dados experimentais nos ajudam a ampliar o significado dos conceitos (compreendê-los melhor) o significado dos conceitos (e as unidades conceituais de análise) nos ajudam a compreender a essência dos dados, suas relações internas ou sua totalidade.

Num primeiro momento, as bases teóricas que nos fundamentavam para a elaboração dessas unidades conceituais de análise estavam relacionadas aos seguintes conceitos: formação do pensamento teórico e formação do pensamento empírico; motivo; ações e operações (estrutura da atividade); atividade de ensino e atividade de aprendizagem; atividade criadora ou imaginação.

Concomitantemente ao processo de elaboração dos instrumentos conceituais para as nossas análises, demos início à organização dos dados gravados em vídeo. Assim, assistimos às dez aulas gravadas, realizando uma transcrição parcial e/ou completa de algumas cenas ou situações que julgávamos pertinentes para o nosso objetivo de pesquisa e para as discussões teóricas que queríamos fazer. Havíamos já elaborado uma tabela que resumia os tópicos trabalhados em cada encontro a partir da temática da atividade circense.

\begin{tabular}{|l|l|}
\hline AULA 1 & $\begin{array}{l}\text { - Introdução ao tema de trabalho do semestre (a elaboração de um espetáculo } \\
\text { de circo para os pais e as outras crianças do Clube); } \\
\text { - levantamento de idéias sobre os elementos necessários para se criar um } \\
\text { espetáculo; } \\
\text { - sessão de vídeo (análise inicial dos elementos de um espetáculo). }\end{array}$ \\
\hline AULA 2 & $\begin{array}{l}\text { - Sobre os conceitos de circo (função social) e introdução aos tipos de cenas } \\
\text { (intencionalidades). }\end{array}$ \\
\hline AULA 3 & $\begin{array}{l}\text { - criação de cenas (de acordo com uma intencionalidade) com caixas } \\
\text { construídas de papel; } \\
\text { - vivência dos movimentos de alguns personagens. }\end{array}$ \\
\hline AULA 4 & $\begin{array}{l}\text { - estudo dos elementos necessários para criar uma cena de circo e seus } \\
\text { conceitos; } \\
\text { - divisão dos personagens para o espetáculo; } \\
\text { - elaboração dos planejamentos. }\end{array}$ \\
\hline AULA 5 & $\begin{array}{l}\text {-socialização dos planejamentos; } \\
\text { - ensaios nos subgrupos. }\end{array}$ \\
\hline AULA 6 & - primeira apresentação geral (ensaio geral) \\
\hline
\end{tabular}




\begin{tabular}{|l|l|}
\hline AULA 7 & - avaliação das cenas e confecção de materiais para a apresentação \\
\hline AULA 8 & $\begin{array}{l}\text { - ensaios nos grupos; } \\
\text { - ensaio geral e avaliação. }\end{array}$ \\
\hline AULA 9 & - ensaio geral e avaliação. \\
\hline AULA 10 & - ensaio geral e avaliação. (não está gravado) \\
\hline Espetáculo & Apresentação para pais, educadores e alunos do Clube de Matemática. \\
\hline
\end{tabular}

Quadro 4: Resumo dos tópicos trabalhados nas aulas do experimento didático.

Essa primeira organização dos dados deu-se, assim, de forma linear, aula a aula, com anotações e comentários sobre algumas cenas que julgávamos mais relevantes. Com base nessa primeira organização e no movimento de elaboração das unidades conceituais de análise, passamos a organizar os dados de um segundo modo: separados por “Temas”. Os Temas surgiram da necessidade que víamos em organizar os dados de modo a aproximar ou reunir cenas ou seqüências de cenas que cronologicamente estavam distantes, mas que se aproximavam de um ponto de vista lógico (do desenvolvimento do sujeito ou de um conceito).

Nessa altura, já tínhamos uma noção geral das possibilidades de discussões teóricas de nossos dados. Conseguíamos visualizar aquelas categorias teóricas mais gerais que nos fundamentavam (atividade; mediação; trabalho) e os conceitos da teoria histórico-cultural atrelados a elas (formação do pensamento teórico e formação do pensamento empírico; motivo, ações e operações - estrutura da atividade -; atividade de ensino e atividade de estudo; atividade criadora ou imaginação) inseridos e/ou dialogando com algumas cenas e situações advindas do experimento didático.

A partir dessa perspectiva e desse movimento elaboramos quatro unidades conceituais de análise, quatro conceitos que serviriam como instrumentos para a análise dos dados. A primeira delas está relacionada à atividade docente, tanto ao processo de planejamento da unidade de ensino, quanto das intervenções dos educadores. As outras três, referem-se às atividades discentes. As unidades conceituais de análise são: 1) Atividade Orientadora de Ensino; 2) Imaginação e criação; 3) Formação de conceitos; 4) Motivo e motivação.

Explicitado esse movimento que nos levou à criação dessas unidades conceituais de análise passaremos, a seguir, a uma descrição mais detalhada de cada unidade e do seu papel para as discussões de nossos dados com o experimento didático. 


\section{1) A Atividade Orientadora de Ensino: a organização das ações de aprendizagem e as intervenções dos educadores}

A intencionalidade ou consciência dos professores quanto ao objeto de ensino, isto é, a clareza quanto aos elementos e conceitos essenciais de serem ensinados e aprendidos, é uma questão bastante importante na dinâmica de ensino e aprendizagem. Em nosso trabalho, ter os elementos de organização e criação das cenas como objetivos pedagógicos, como o objeto de ensino que deveria se transformar continuamente em objeto de aprendizagem para as crianças, permitiu aos professores o permanente processo de construção e organização da atividade dos estudantes como uma atividade de estudo do circo. A clareza do objeto de ensino e aprendizagem permite a realização de intervenções “adequadas” a esse fim, ou intervenções cuja qualidade garanta o direcionamento das atividades e ações das crianças para o objeto de aprendizagem desejado.

Desta forma, podemos afirmar que o ensino pode ser organizado de modo a se articular com a formação do pensamento teórico, ou com a criação da atividade de estudo, sobretudo ao garantir momentos intencionais de análise e síntese do objeto a ser ensinado e aprendido; garantir momentos em que esse objeto de ensino e aprendizagem fosse o "objeto de consciência” (LEONTIEV, 1983) dos estudantes.

Importa com a presente unidade conceitual de análise, analisarmos esses tipos de intervenções dos educadores, bem como o planejamento ou o modo de organização do ensino, capazes de contribuir para a organização das atividades dos educandos em forma de atividade de estudo. Portanto, ações de ensino e de aprendizagem que se vinculem a organização do pensamento teórico nos estudantes (apropriação dos conceitos teóricos), explicitando o objeto a ser ensinado e aprendido (os conceitos para a criação das cenas) e os transformando tanto em objeto de consciência do educador (objeto de seu ensino), quanto em objeto de consciência dos estudantes (objeto de sua aprendizagem).

Nesse movimento, poderemos analisar ou esboçar as ações e as operações de aprendizagem geradas pelos educadores, bem como os problemas de aprendizagem explicitados e as situações desencadeadoras de aprendizagem criadas para as situações de ensino. Em outras palavras, buscaremos explicitar a estrutura da Atividade Orientadora de Ensino, tanto no planejamento realizado, quanto nas intervenções ocorridas.

Além da questão da intencionalidade e consciência do objeto de ensino por parte do educador, caberá discutir, também, uma questão bastante importante sobre a organização do ensino: o ensino organizado é o que cria as condições para que os educandos sejam de fato sujeitos e ativos em seus processos de aprendizagem. Ser ativo, tomar parte da atividade 
enquanto sujeito, não pressupõe mínimas intervenções dos educadores, no sentido de "dar mais espaço” para os educandos se expressarem e agirem. Pressupõe, sim, máximas intervenções dos educadores, para que essa expressividade e ações dos sujeitos possam se dar de modo articulado com a finalidade do ensino proposto.

Caberá, também, discutirmos o processo de organização do ensino para a formação de conceitos e, mais amplamente, para a formação do pensamento teórico. Sobre isso poderemos destacar um aspecto: a organização da apropriação do conceito em que o professor declara a definição do conceito ou mesmo expõe sua conceituação, ou em que propõe tarefas a serem resolvidas pelos educandos, pautados em um princípio orientador.

A principio, não se trata de rechaçar a definição conceitual como instrumento de ensino dos conceitos. A questão é debatermos o processo de formação conceitual, enquanto relações entre conceitos e como um processo vivo, não como um processo memorístico. Em nosso experimento didático, havíamos planejado alguns momentos de resoluções de “problemas de aprendizagem” (conforme definição de Rubtsov, 1996) para a formação conceitual dos elementos necessários para a criação das cenas, problemas esses que serviriam como disparadores e como orientadores para a apropriação dos conceitos. A disponibilidade de tempo para as aulas (menos do que supúnhamos) nos fez realizar alguns ajustes quanto ao trabalho com a resolução de problemas como ponto de partida da formação dos conceitos.

De todo modo, podemos analisar, aqui, um ponto importante: ainda que a proposta de resolução de problemas de aprendizagem seja um elemento fundamental para a formação conceitual, trata-se não do ponto final da formação do conceito em questão, mas sim do seu ponto de partida. Assim, interessa-nos, nas discussões a partir dessa unidade conceitual de análise, esboçarmos as ações realizadas e as ações possíveis dos educadores para a formação de conceitos teóricos nas crianças e, mais especificamente, para a formação do pensamento estético-artístico.

\section{2) A criação e imaginação: uma dimensão do pensamento teórico.}

O ponto de maior interesse nas discussões ocorridas a partir dessa unidade (a julgar por nossos dados e pela potencialidade deles) é a questão da possibilidade de criação de uma outra realidade no campo da arte: a criação de um objeto artístico ou de uma realidade artística. A atividade criadora artística segue as mesmas leis de qualquer atividade de criação humana (e mais amplamente as leis da atividade humana de trabalho) exigindo do sujeito uma consciência dos fins que quer atingir; exige, portanto, a existência explícita de uma intencionalidade e a composição (ou combinação) dos elementos disponíveis na realidade de 
um modo singular. Isto quer dizer que a composição ou organização desses elementos da realidade deve se dar de um modo distinto daquele vivenciado na vida cotidiana do sujeito. Daí de se dizer que o sujeito cria efetivamente uma nova realidade.

Em nossa pesquisa, os elementos que deveriam ser compostos de forma “original” e vinculados a um objetivo explícito seriam: a intencionalidade artística (o sentimento que quero provocar no público); o ângulo de visão (a forma como vou dispor a cena no espaço, de modo a propiciar a melhor visão para o público, de acordo com o movimento que vou realizar e com o meu objetivo); a coreografia (a organização da cena no tempo e no espaço); a narração (momentos intencionais de comunicação com o público, direta ou indiretamente); os movimentos (as ações dos personagens que serão realizadas); os acessórios (roupas, maquiagem e cenários); a música (como forma de ratificar a intenção da minha cena).

A partir desse debate é que poderemos discutir os movimentos de criação criativa e de criação reprodutiva, tal qual apontado por Luria (2005) e Vigotsky (2004). A imaginação reprodutiva, como já vimos, está determinada (e não apenas vinculada) à experiência prática do sujeito ou àquelas suas experiências mais imediatas, guardando estreita relação com a memória e/ou com um modelo previamente dado. Trata-se de uma criação mais de “memória”, da reprodução mais ou menos exata de algo já vivenciado pelo sujeito.

A imaginação criativa, por outro lado, está vinculada ao pensamento lógico-verbal, o que liberta o sujeito do determinismo das suas experiências imediatas, permitindo que ele as utilize de um modo verdadeiramente arbitrário e consciente, compondo com esses elementos uma nova realidade.

Em nossos dados, podemos observar algumas cenas que pareciam ter um vínculo direto com as situações cotidianas vivenciadas ou dominadas pelas crianças. De alguma forma, era o movimento "cru”, a habilidade em si mesma ou a brincadeira em si mesma, sem a composição de uma cena efetivamente; sem articular os elementos artísticos que foram objeto de ensino e, assim, sem criar uma nova realidade (um objeto artístico), ao menos não de forma intencional, consciente e voluntária.

A unidade conceitual “imaginação e criação" abre-nos, também, a possibilidade de análise do papel da imitação para a realização dessa atividade. O conceito de imitação para a teoria vigotskiana refere-se à forma de apropriação das condutas culturais por parte dos sujeitos. Imitar, portanto, é uma forma de desenvolver novas condutas e, assim, não se constitui num fim, mas num meio para o desenvolvimento cultural. 
[...] o desenvolvimento decorrente da colaboração via imitação, que é a fonte do surgimento de todas as propriedades especificamente humanas da consciência, o desenvolvimento decorrente da aprendizagem é o fato fundamental. Assim, o momento central para toda a psicologia da aprendizagem é a possibilidade de que a colaboração se eleve a um grau superior de possibilidades intelectuais, a possibilidade de passar daquilo que a criança consegue fazer para aquilo que ela não consegue por meio da imitação. Nisto se baseia toda a importância da aprendizagem para o desenvolvimento, e é isto o que constitui o conteúdo de zona de desenvolvimento imediato. A imitação, se concebida em sentido amplo, é a forma principal em que se realiza a influência da aprendizagem sobre o desenvolvimento (VIGOTSKI, 2009 p.331).

Em termos gerais, o conceito de imitação precisa ser compreendido e estudado juntamente com a lei genética fundamental de Vygotski (1995) em que os processos psicológicos se formam primeiro num plano interpsíquico e posteriormente num plano intrapsíquico, e com as suas concepções de desenvolvimento e aprendizagem. De modo mais específicos, o conceito de imitação precisa ser compreendido e estudado juntamente com os conceitos de colaboração e de zona de desenvolvimento próximo. Embora esses três conceitos sejam processos distintos, relativamente autônomos, devem ser compreendidos nas relações que estabelecem um com o outro.

Ao falar em imitação não nos referimos a uma imitação mecânica, automática, sem sentido, mas a uma imitação racional, baseada na compreensão da operação intelectual que se imita. Quer dizer, por uma parte restringimos o significado do termo, o referimos unicamente a esfera das operações mais ou menos diretamente relacionadas com a atividade racional da criança e, por outra, ampliamos o significado do termo, empregando a palavra 'imitação', aplicando a toda atividade que a criança não realiza por si só, mas em colaboração com um adulto ou outras crianças. Tudo quanto uma criança não é capaz de realizar por si mesma, mas pode aprender sob a direção ou a colaboração do adulto ou com a ajuda de perguntas orientadoras, é incluído por nós na área da imitação (VYGOTSKI, 1996, p.268).

Como forma de sintetizar os debates relacionados a essa unidade conceitual, e esboçar as relações entre os tipos de atividade criativa, a imitação e a formação do pensamento estético-artístico, apresentamos o seguinte esquema: 


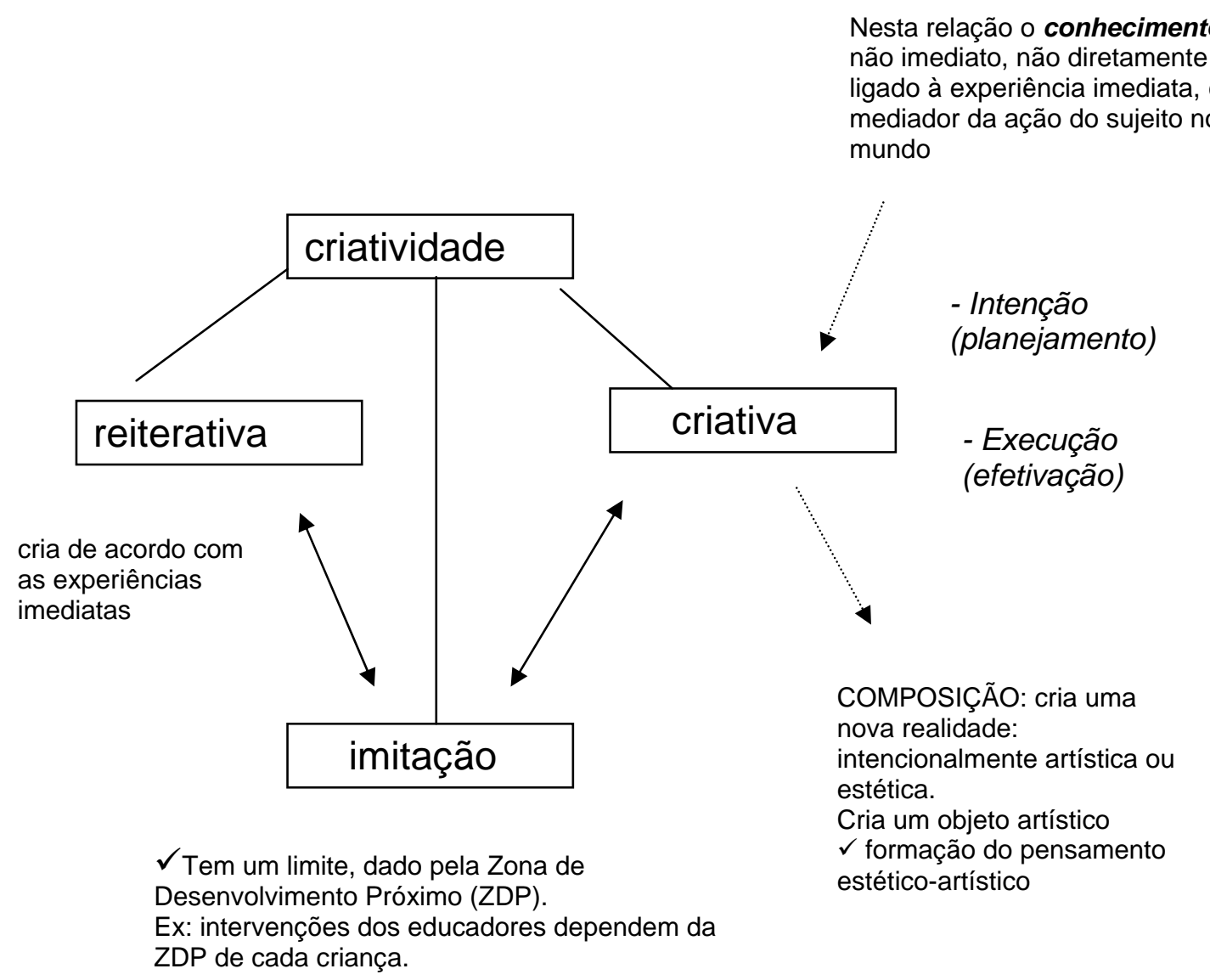

Figura 1: As relações da criatividade na atividade artística.

Por fim, serão válidos os estudos ou análises das cenas produzidas pelas crianças tão somente no seu movimento de produção, isto é, na articulação com o planejamento e os ensaios e nos processos de ações que se desenrolaram a partir das intervenções dos educadores. A boa cena pela boa cena, pode nos remeter a um beco sem saída: a questão do “talento”. Mais uma vez, interessa-nos analisar o movimento de apropriação do conhecimento artístico e da atividade artística (enquanto modo de ação do sujeito no mundo) por meio da atividade de estudo. Neste caso, há que se considerar diferentes pontos de partida para cada criança e vale analisar o processo ou percurso de cada estudante durante a atividade de ensino proposta.

\section{3) Formação de conceitos.}

Por meio da apropriação de determinados conceitos relacionados à criação das cenas circenses, objetivávamos que os estudantes adquirissem um modo geral de ação para a 
construção das cenas. A apropriação dos conceitos implica em uma possibilidade de mudança nas ações do sujeito.

Nesta unidade conceitual pretendemos analisar, justamente, esse movimento de apropriação conceitual por parte das crianças. Deste ponto de vista, serão válidas as análises das cenas produzidas pelas crianças tão somente no seu movimento de produção, isto é, na articulação com o planejamento e com os ensaios que realizaram e nos processos de ações que se desenrolaram a partir das intervenções dos educadores. A análise do movimento conceitual nos permitirá uma aproximação do processo de apropriação do conhecimento artístico e da atividade artística (enquanto modos de ação do sujeito no mundo) por meio da atividade de estudo.

A presente unidade conceitual, portanto, poderá também contribuir para o debate de uma outra questão: ainda que a criança estabeleça uma relação não espontânea com a atividade de criação e/ou análise das cenas, podemos pensar que pode se tratar de uma relação empírica e não verdadeiramente teórica com a realidade. Será necessário, então, analisarmos esse processo de conscientização, buscando identificar as suas articulações com a formação do pensamento teórico e, portanto, com a apropriação de conceitos.

Algumas questões podem ser propostas: a) Como caracterizar a relação da criança com a cena como sendo efetivamente mediada pelo conhecimento (e pelo conhecimento teórico)? b) Como caracterizar, no campo das atividades artísticas ou das objetivações genéricas artísticas, esse tipo especial de generalização (não espontâneo)? c) Será que pelo simples fato de estar inserido em uma atividade de ensino intencionalmente organizada, podemos supor que a criança tenha o conhecimento como mediador de sua atividade? d) Como identificar que tais conhecimentos e seus significados estejam, de fato, ocupando a consciência do estudante, sejam o objeto de sua consciência?

Essas questões servirão de referências para as análises dos episódios relacionados à formação dos conceitos. Destacaremos, aqui, para uma primeira consideração, a segunda questão elaborada por nós.

O fato de um sujeito ter suas ações voltadas para um objetivo (no caso a elaboração do espetáculo e/ou de uma cena), nos indica que o sujeito está em atividade. Contudo, não podemos afirmar diante disso, que ele esteja, de fato, em atividade de estudo, no sentido de que ele tenha como objeto de sua aprendizagem o conhecimento teórico. A questão parece ser, então, a de analisarmos se a relação que ele estabelece com a criação das cenas e do espetáculo é uma relação mediada pelos conhecimentos e conceitos que foram trabalhados, se há uma busca em aprender e uma valorização do conhecimento como orientadores de suas 
ações ou não. Isto é, se o conhecimento cumpre para o sujeito um papel central e mediador de suas ações e se ele está conscientemente voltado para a criação de um objeto artístico.

Portanto, um ponto importante de análise vai ser a consciência da criança com esse processo de elaboração das cenas e do espetáculo, se é isso que a move, se ela busca intencionalmente melhorar as cenas, se está explícito para ela a elaboração da cena: "para quem” e "para que” (finalidade do artista) e, nesta relação, o movimento dos conhecimentos empíricos e teóricos durante a atividade de ensino e aprendizagem.

\section{4) Motivo e motivação: ação, operação e objeto da consciência}

Participar de atividades corporais pode ser, para muitos (embora devemos dizer que não para todos), suficientemente motivante, ou em si mesmo motivador. Poder testar destrezas, mostrar o que sabe, aprender novas habilidades, para muitos sujeitos, é suficiente para os mobilizar a realizar as tarefas.

Em nosso experimento didático o que estava em jogo como centro do trabalho não era a execução dos movimentos em si, mas a apropriação do pensamento estético-artístico. Neste sentido, e em termos leontievanos, o movimento não deve ocupar o lugar de ação na atividade da criança (aquilo para que ela está voltada, ou o seu objetivo), mas de operação (aquilo que lhe permite concretizar seu objetivo: um instrumento). Esse processo de transformação do movimento de ação para operação consciente pôde ser investigado a partir de nossos dados e nos fornecer indícios sobre a organização do ensino da educação física e sobre o motivo dos sujeitos em atividade.

Estabelecemos uma distinção entre motivo e motivação. O motivo que pretendíamos criar ou a necessidade para engajar-se na atividade era o de conhecer as formas de organizar um espetáculo de circo, de compor uma cena circense, criando conscientemente um objeto artístico. Enquanto o motivo dirige-se ao objeto da própria atividade (em nosso experimento, criar cenas circenses), a motivação refere-se a um vínculo geralmente imediato e relativamente espontâneo (não consciente) da criança com a ação e/ou com a atividade em que está inserida.

Em nossa pesquisa o processo criativo estava em primeiro plano na organização do ensino. Mas não se tratava da criação em si mesma, ou da criação pela criação, mas de um processo, de uma ação e de uma atividade intencionalmente organizados, de uma atividade de criação orientada por um modo geral de ação. Esse modo geral de ação, como uma forma sintetizada da relação que o homem foi estabelecendo com o fenômeno de criação de cenas, 
representa a orientação para a resolução dos problemas concretos e práticos com os quais as crianças iriam se deparar: criar uma cena com o personagem escolhido.

Deste modo, o central não era o trabalho com a criatividade em si, mas com a idéia da composição (DAVIDOV, 1988) de cenas, que exprimissem a manifestação do pensamento teórico no campo da arte, via processos de análise e síntese dos elementos da realidade relacionados à criação das cenas.

O conceito de atividade está vinculado diretamente ao conceito de motivo. Isto significa que a atividade é o processo originado e dirigido por um motivo, dentro do qual a necessidade toma forma de objeto (LEONTIEV, 1983). O motivo real de um sujeito é o objeto da sua própria atividade. Entretanto, o motivo só nasce a partir de uma necessidade. A necessidade, por sua vez, só se concretiza ao se materializar em um objeto, ao encontrar um objeto que satisfaça essa necessidade. E é nesse movimento de satisfação da necessidade que surge o motivo.

Em nossos dados, podemos esboçar análises sobre a relação do sujeito com a atividade que ele realiza, seus motivos, ações e operações.

\subsubsection{Os episódios de ensino.}

Ainda que a função central das unidades conceituais de análise seja a de proporcionar um debate verdadeiramente conceitual dos elementos da realidade tomados em sua totalidade, existe, também, nas unidades conceituais de análise uma dimensão organizadora dos dados. Após elaborarmos as unidades, explicitando em cada uma delas os conceitos que deveríamos discutir e desenvolver, pudemos organizar os nossos dados (dispostos, então, em temas ou agrupamentos temáticos) a partir de núcleos conceituais relacionados às unidades elaboradas. Esse passo organizativo dos dados nos permitiu enxergá-los com o “olhar” das próprias unidades conceituais, isto é, os dados da pesquisa passaram a ser vistos e selecionados ou como ilustradores para o debate de determinadas questões conceituais ou como disparadores para esse mesmo debate.

Assim, a organização dos dados a partir das unidades conceituais nos fez elaborar uma série de “pré-análises” das cenas selecionadas; fez-nos apontar as possibilidades de debates conceituais a partir de cada cena. 
Faltava, então, um segundo momento organizativo dos dados dentro das unidades, que julgávamos importante para iniciarmos o processo de análise propriamente dito. As diversas cenas selecionadas, e ainda que muitas delas se referissem a um conjunto de cenas e não a uma cena isolada, deveriam ser compostas em “episódios de ensino” (MOURA, 1992; 2004).

Os episódios poderão ser frases escritas ou faladas, gestos e ações que constituem cenas que podem revelar interdependência entre os elementos de uma ação formadora. Assim, os episódios não são definidos a partir de um conjunto de ações lineares. Pode ser que uma afirmação de um participante de uma atividade não tenha impacto imediato sobre os outros sujeitos da coletividade. Esse impacto poderá estar revelado em um outro momento em que o sujeito foi solicitado a utilizar-se de algum conhecimento para participar de uma ação no coletivo (MOURA, 2004, p.276, grifos do autor).

Os episódios de ensino podem ser definidos, então, como um conjunto de cenas "em que fica evidente uma situação de conflito que pode levar à aprendizagem do novo conceito” (MOURA, 1992, p.77). Neles, existe a intenção de apreender o processo de desenvolvimento de uma situação de ensino e aprendizagem e o processo de desenvolvimento dos sujeitos que dela tomam parte. Os episódios, deste modo, apontam-nos já para uma necessidade teóricometodológica das pesquisas científicas: analisar o processo de desenvolvimento das situações/ fenômenos e não apenas um ou mesmo diversos elementos que compõem essa situação.

A organização das diversas cenas (já divididas em suas respectivas unidades conceituais de análise) em episódios nos pareceu ser uma forma de organizar o processo de exposição da pesquisa, isto é, de direcionar o leitor para o movimento de nossas análises. Os episódios, ao aglutinarem de forma lógica e subordinada a um determinado conceito teórico, situações em seu processo de desenvolvimento, permitem que os dados assumam a função de disparadores ou de ilustradores das reflexões teóricas que desejávamos realizar.

A seguir, apresentamos uma tabela síntese com as nossas unidades conceituais de análise, o debate teórico mais amplo que ela nos proporciona e os episódios analisados por nós em cada uma destas unidades. 


\begin{tabular}{|c|c|c|}
\hline $\begin{array}{l}\text { UNIDADE } \\
\text { CONCEITUAL DE } \\
\text { ANÁLISE }\end{array}$ & DEBATE TEÓRICO & EPISÓDIOS ANALISADOS \\
\hline $\begin{array}{l}\text { 1) Atividade } \\
\text { Orientadora de } \\
\text { Ensino }\end{array}$ & $\begin{array}{l}\text { Organização do ensino } \\
\text { para a formação do } \\
\text { pensamento estético- } \\
\text { artístico }\end{array}$ & $\begin{array}{l}\text { Episódio 1: Intervenções nas ações } \\
\text { práticas dos educandos; } \\
\text { Episódio 2: Intervenções nas ações } \\
\text { de estudo; } \\
\text { Episódio 3: Estrutura de } \\
\text { organização do ensino } \\
\text { Episódio 4: Intervenções dos } \\
\text { educadores no processo de criação } \\
\text { das cenas. }\end{array}$ \\
\hline $\begin{array}{l}\text { 2)Criação e } \\
\text { imaginação como } \\
\text { dimensão do } \\
\text { pensamento teórico. }\end{array}$ & $\begin{array}{l}\text { Aprendizagem e } \\
\text { desenvolvimento (FPS): } \\
\text { criatividade criativa como } \\
\text { dimensão do pensamento } \\
\text { teórico }\end{array}$ & $\begin{array}{l}\text { Episódio 5: Relação do sujeito com } \\
\text { o movimento humano: o } \\
\text { movimento como ação ou operação } \\
\text { da atividade; } \\
\text { Episódio 6: Relação do sujeito com } \\
\text { a atividade criadora: criação } \\
\text { reprodutiva e criação criativa. }\end{array}$ \\
\hline $\begin{array}{l}\text { 3) Formação de } \\
\text { conceitos }\end{array}$ & $\begin{array}{l}\text { Aprendizagem e } \\
\text { desenvolvimento (FPS): a } \\
\text { composição como } \\
\text { expressão do pensamento } \\
\text { teórico no campo das } \\
\text { atividades artísticas }\end{array}$ & $\begin{array}{l}\text { Episódio 7: Formação conceitual } \\
\text { da cena engraçada: o movimento } \\
\text { de reflexão do conceito pelas } \\
\text { crianças } \\
\text { Episódio 8: Movimento de } \\
\text { apropriação do ângulo de visão: o } \\
\text { movimento das ações das crianças } \\
\text { com o conceito } \\
\text { Episódio 9: Movimento de } \\
\text { formação do conceito de narrador: } \\
\text { o movimento da atividade do sujeito }\end{array}$ \\
\hline 4) Motivo e motivação & Finalidade do ensino. & $\begin{array}{l}\text { Episódio 10: Relação com a } \\
\text { finalidade da atividade: movimento } \\
\text { como operação ou como ação e } \\
\text { motivo da atividade }\end{array}$ \\
\hline
\end{tabular}

Quadro 5: Os episódios de ensino e de aprendizagem e as unidades conceituais de análise. 
Descrevemos de forma mais detalhada esse processo de construção ou elaboração das unidades conceituais de análise e de organização dos dados de nossa pesquisa, porque julgamos que esse movimento expressa o caminho metodológico que pensamos ser fundamental para as investigações científicas: a busca de elaborações explicativas da realidade investigada, aproximando-nos, através delas, da essência de tal realidade. Como diz Vygotski “para uma análise dinâmica, explicar um fenômeno significa esclarecer sua verdadeira origem, seus nexos dinâmico-causais e sua relação com outros processos que determinam seu desenvolvimento” (1995, p.112).

Assim, se tivéssemos parado nossa pesquisa neste momento organizativo, em que obtivemos provavelmente as máximas possibilidades de organização dos dados, teríamos parado a pesquisa justamente no ponto em que ela deveria começar. A organização dos dados, assim como a “obtenção” dos dados fazem parte de todo o processo de análise da pesquisa. Mas nem uma, nem outra, podem ser confundidas com a análise dos dados propriamente dita.

Com efeito, se o objeto fenotipicamente fora igual genotipicamente, quer dizer, se as manifestações externas do objeto tal como costuma ver-se todos os dias realmente expressassem as verdadeiras relações das coisas, a ciência estaria completamente de mais, já que a simples observação, a simples experiência cotidiana, a simples anotação dos fatos substituiria por completo a análise científica. Tudo quanto percebêssemos diretamente seria objeto de nosso conhecimento científico (VYGOTSKI, 1995, p.104).

No próximo tópico, realizamos a análise dos episódios de ensino e de aprendizagem. 
6. OS DADOS E AS ANÁLISES: AS ABSTRAÇÕES E AS SÍNTESES DA PESQUISA.

\subsection{O processo de organização da unidade de ensino do circo.}

\subsubsection{A unidade fundamental do objeto circo.}

Para atingirmos os objetivos de nossa pesquisa - investigar o processo de organização do ensino para a formação do pensamento estético-artístico - e considerando tanto a área de conhecimento geral a qual nos vinculamos (a educação física), quanto os conhecimentos e domínios que tínhamos das diversas manifestações da cultura corporal, elegemos como atividade de ensino e aprendizagem de nosso experimento didático o circo. Ao elegermos o circo como uma atividade de ensino pertencente à esfera artística, precisávamos definir ou explicitar quais os seus conteúdos fundamentais, quais os conceitos essenciais presentes no circo e necessários de serem apropriados pelos educandos para que pudessem desenvolver o pensamento estético-artístico. Precisávamos, como ponto de partida para a organização do ensino, definir a unidade fundamental do circo, isto é, o modo de ação historicamente presente e desenvolvido no circo e que o relaciona de forma mais explícita a uma atividade estética e artística; precisávamos definir a essência dessa atividade, necessária de ser apropriada pelos educandos.

A definição da unidade fundamental de um objeto de estudo é essencial para a organização do ensino, posto que ela se configura como o elemento orientador de todas as ações de aprendizagem e de ensino. Ela orienta a elaboração das abstrações conceituais que os estudantes deverão se apropriar, bem como as ações de aprendizagem dos estudantes e as de ensino dos educadores.

Embora diferentes áreas do conhecimento enxerguem aspectos distintos em um mesmo objeto, ou ressaltem determinados aspectos em detrimento de outros, o objeto em si mesmo, de acordo com suas propriedades e as relações objetivas que possui com a realidade (sua história de desenvolvimento), apresenta uma determinada unidade fundamental, que independe do olhar que lançamos a ele $^{38}$. Pensando em nosso objeto de ensino (o circo),

\footnotetext{
${ }^{38}$ O olhar de cada sujeito - ou a sua concepção de mundo - não interfere na objetividade do conhecimento presente em um dado fenômeno, isto é, não muda o que o fenômeno é em si. Mas o nosso olhar pode interferir,e invariavelmente interfere, no processo de explicitação do conhecimento objetivo sobre o fenômeno.
} 
podemos esboçar as diferentes relações que outras áreas de conhecimento (tais quais a física e a educação física presente nas academias de ginástica), estabelecem com ele.

Para a física, o circo configura-se como um campo de estudo, uma manifestação empírica de fenômenos relacionados ao estudo da mecânica, da gravidade, da aceleração dos corpos e do centro de equilíbrio. Para as academias de ginástica e acompanhando a lógica do mercado (do corpo), o circo configura-se como um meio de “queimar calorias” e enrijecer as musculaturas. Nestes casos, tanto o físico, quanto às academias, partem de um mesmo objeto concreto, ainda que produzam conhecimentos bastante distintos (da velocidade de movimento em um caso, dos benefícios aeróbios em outro) e ações também distintas com esse objeto. Entretanto, o que nos importa aqui, a partir desse exemplo, é discutirmos se a física e as academias de ginásticas, lidam, de fato, com a unidade fundamental do circo, embora cada um a seu modo. A resposta a essa questão é, para nós, um sonoro não.

A determinação da unidade fundamental de um objeto, como já afirmamos, não é arbitrária, a depender do interesse e do olhar de quem o caracteriza. Ela existe objetivamente na realidade, na forma de relações historicamente estabelecidas entre esse objeto e a realidade e, assim, não precisa e não pode ser recriada a cada instante e por cada pessoa, mas, antes, precisa ser revelada. O físico e as academias de ginástica não trabalham com a unidade fundamental do circo; não trabalham com o circo como uma atividade (artística), mas com um ou outro aspecto/elemento que fazem parte do circo.

Qual seria, então, a unidade fundamental do circo enquanto uma atividade artística? O que caracteriza o circo em sua essência? Para chegarmos a essa resposta foi necessário analisarmos, destrincharmos, as relações e os modos de ação presentes nessa atividade, separando aquilo que é apenas a aparência do objeto daquilo que se constitui na sua verdadeira essência.

Elencar todos os elementos que compõem o circo é, sem dúvida, uma tarefa importante, contudo, não é, em si, suficiente. A essência do circo (e de qualquer objeto) não está em um ou vários elementos juntos, mas em uma determinada relação entre esses elementos. Portanto, mais do que estabelecermos os elementos mais importantes presentes na atividade circense, precisamos olhar para esses elementos estabelecendo as relações fundamentais existentes entre eles, bem como com a atividade como um todo. É preciso descobrir a atividade em seu processo de desenvolvimento.

Os elementos que compõe uma atividade circense (movimentos corporais, personagens, público, ângulo de visão, coreografia, enredo, intencionalidade, figurino, música, maquiagem, cenários...), ajudam-nos a formar um quadro da atividade, embora, a 
princípio, seja um quadro um tanto quanto caótico (momento I, quadro 6). Caótico porque o conhecimento sobre o objeto como um todo e o conhecimento sobre cada um dos seus elementos, ainda se encontra no plano do concreto sensível. As abstrações ainda estão por serem feitas e são elas que nos remetem à possibilidade de compreensão do objeto como um objeto concreto pensado.

Mas é a partir desse primeiro movimento que podemos avançar na elaboração das abstrações conceituais do objeto, bem como estabelecer as relações objetivamente existentes entre os elementos elencados. Ainda assim, chegamos não a uma conceituação do objeto circo, mas a definições ou hierarquias entre os elementos, criando "unidades fundamentais aparentes” (momento II, quadro 6).

Através desse processo, as abstrações podem surgir (ou ser elaboradas) e, assim, as relações reais entre os elementos podem ser estabelecidas, dando origem à explicitação da unidade fundamental do circo (momento III, quadro 6).

Esse processo está resumido no quadro abaixo:

\begin{tabular}{|l|l|l|}
\hline \multicolumn{3}{|c|}{ ATIVIDADE ARTÍSTICA: CIRCO } \\
\hline \multicolumn{2}{|c|}{ Processo de elaboração da unidade fundamental) } \\
\hline $\begin{array}{l}\text { I) Determinação dos } \\
\text { Elementos. }\end{array}$ & $\begin{array}{l}\text { II) Objeto Aparente. } \\
\text { Hierarquização entre os } \\
\text { Partes que compõe o circo: } \\
\text { elementos: as } \\
\text { características mais } \\
\text { descriçãos do do “concreto } \\
\text { sensível” }\end{array}$ & $\begin{array}{l}\text { III) Objeto real/ unidade } \\
\text { fundamental. } \\
\text { Explicitação das relações } \\
\text { essenciais entre os } \\
\text { elementos e presentes no } \\
\text { como as características } \\
\text { definidoras do objeto }\end{array}$ \\
\hline $\begin{array}{l}\checkmark \text { Movimentos corporais, } \\
\text { personagens, ângulo de } \\
\text { visão, coreografia, enredo, } \\
\text { intencionalidade, figurino, } \\
\text { música, maquiagem, } \\
\text { cenários... }\end{array}$ & $\begin{array}{l}\checkmark \text { As ações corporais } \\
\text { (movimentos) }\end{array}$ & $\checkmark$ Composição de Cenas \\
\hline
\end{tabular}

Quadro 6: O processo de explicitação da unidade fundamental do circo.

Ratificando a importância da unidade fundamental de um objeto, tanto para a compreensão de sua essência, quanto para a organização de uma atividade de ensino e aprendizagem, elaboramos um quadro que sintetiza a atividade circense a partir da unidade fundamental que encontramos. Nesse quadro, apontamos o modo geral de ação presente no circo (a síntese conceitual geral, qual seja, organizar cenas em que o público possa se 
relacionar com determinados significados artísticos circenses); as suas abstrações conceituais fundamentais (os elementos de criação circense); o seu motivo, suas ações e operações.

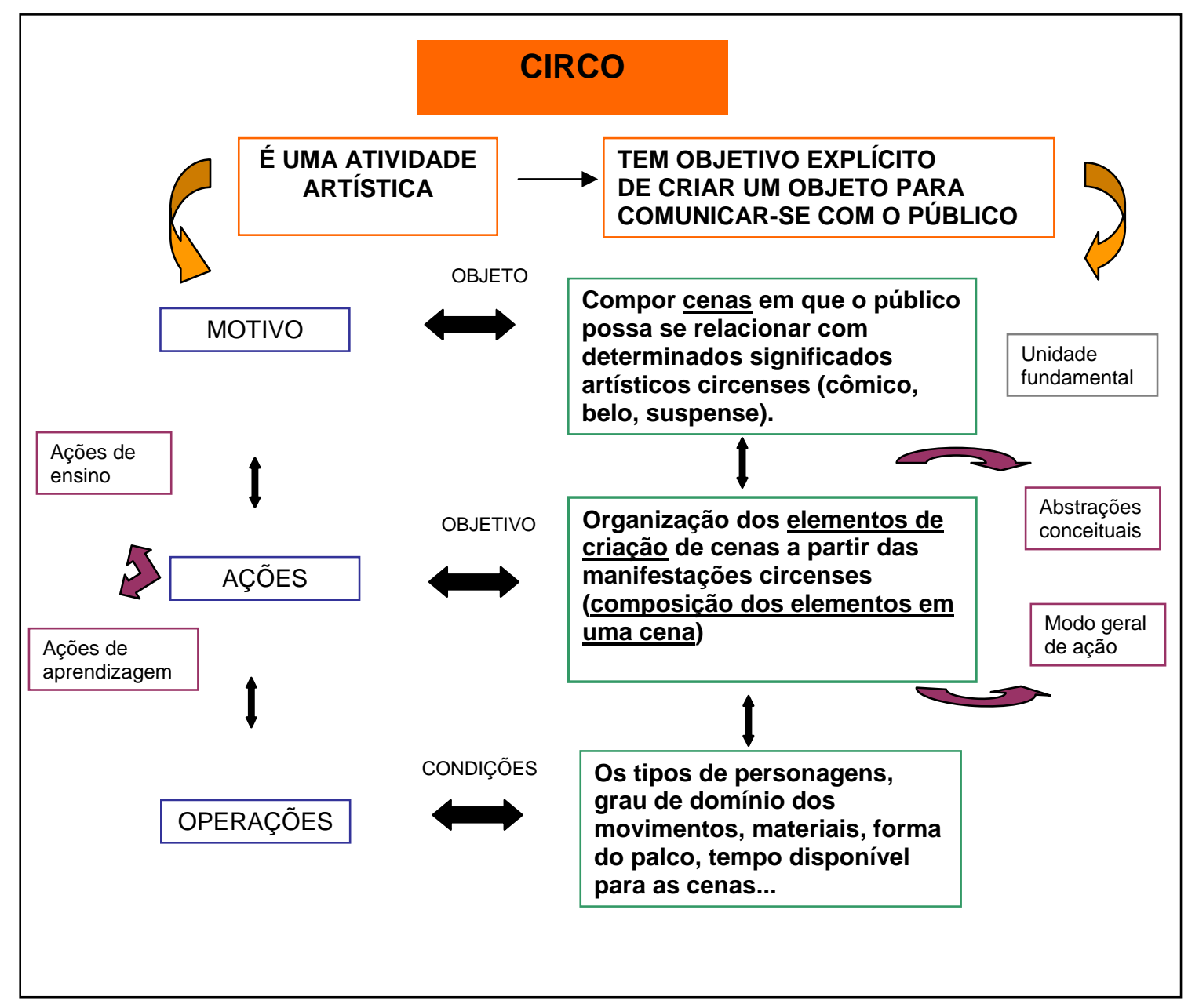

Figura 2: Síntese da atividade circense a partir da sua unidade fundamental.

Os movimentos habilidosos dos acrobatas e equilibristas, as roupas brilhantes e bem delineadas dos contorcionistas, a maquiagem perfeita do palhaço, as luzes e cenários, são aspectos que nos chamam mais a atenção num primeiro momento e, assim, acabam sendo tomados como as características mais importantes ou definidoras do circo. Certamente, tratase de elementos importantes, mas não essenciais em sentido estrito. Isto é, nenhum deles, por si, é capaz de caracterizar a atividade circense. Nenhum deles representa as características necessárias e suficientes para definir o objeto; a célula ou a unidade fundamental de análise do circo. Esta unidade, encontramos, justamente, no processo de composição das cenas. O objeto de ação dos artistas circenses (que posteriormente será transformado em objeto de ação dos educandos) e que representa a unidade fundamental do circo é a criação de cenas. 
O artista circense deve dominar todos aqueles elementos já descritos. Se se trata de um contorcionista, domina os movimentos, escolhe as roupas mais adequadas, prepara a maquiagem, pensa no espaço, na luz, na música que irá tocar etc. Mas a questão central é que nenhum desses elementos existe por si mesmos. Todos eles estão subordinados ao motivo do artista que é criar um objeto artístico. No caso do artista circense, esse objeto artístico, produto de seu trabalho e objeto de apreciação estética do público, são as cenas. Deste modo, cada um dos elementos ganha vida no circo apenas quando entra em movimento no processo de criação de cenas, isto é, quando se subordinam ao motivo central da atividade circense, transformando-se em orientações para as ações dos artistas.

Cada elemento presente no circo indica um modo de ação para a composição das cenas. Os movimentos, a coreografia, o ângulo de visão, os acessórios, a música, o enredo e a intencionalidade, assumem o papel (na atividade circense) de abstrações conceituais, de modos gerais de ação para a criação das cenas. Cada elemento (cada abstração) orienta as ações do artista, indicando o seu objeto de consciência e o seu objeto de ação.

Elegemos os elementos que julgamos centrais no processo de criação de cenas circenses e elaboramos um quadro (quadro 7) com as abstrações conceituais e os modos gerais de ação para cada elemento de criação da cena. Esse quadro nos serviu de referência durante o trabalho pedagógico, como uma síntese das abstrações necessárias de serem ensinadas e aprendidas.

\begin{tabular}{|c|c|c|}
\hline ELEMENTOS & $\begin{array}{l}\text { ABSTRAÇÕES } \\
\text { CONCEITUAIS }\end{array}$ & MODO DE AÇÃO \\
\hline \multirow[t]{2}{*}{ INTENCIONALIDADE } & $\begin{array}{l}\text { - CÔMICA: cenas que errem } \\
\text { propositalmente elementos que } \\
\text { compõem as cenas circenses e/ou que } \\
\text { exagerem características das pessoas } \\
\text { ou das situações. }\end{array}$ & $\begin{array}{l}\text { - criar cenas intencionalmente } \\
\text { erradas com relação aos elementos } \\
\text { que compõem as cenas circenses } \\
\text { (errar os movimentos, a ordem de } \\
\text { entrada no palco, a visão do público } \\
\text { na cena, as falas etc...) } \\
\text { - exagerar características e/ou ações } \\
\text { de personagens do circo ou de } \\
\text { pessoas e situações da vida. }\end{array}$ \\
\hline & $\begin{array}{l}\text { - SUSPENSE: cenas que criam } \\
\text { momentos de tensão, de dúvida e/ou } \\
\text { apreensão para o público }\end{array}$ & $\begin{array}{l}\text { - criar momentos na cena em que se } \\
\text { demonstre para o público uma } \\
\text { pseudo- insegurança do artista ou } \\
\text { uma dificuldade na execução da } \\
\text { cena, fazendo o público percebê-la } \\
\text { como real. }\end{array}$ \\
\hline
\end{tabular}




\begin{tabular}{|c|c|c|}
\hline & $\begin{array}{l}\text { - BELA: cenas que criam momentos } \\
\text { explícitos de apreciação estética para } \\
\text { o público }\end{array}$ & $\begin{array}{l}\text { - criar a impressão de perfeição na } \\
\text { cena, de absoluto domínio de todos } \\
\text { os seus elementos; } \\
\text { - compor os elementos da cena com o } \\
\text { máximo de harmonia. }\end{array}$ \\
\hline ENREDO & $\begin{array}{l}\text { - O desenvolvimento da idéia ou } \\
\text { história da cena. }\end{array}$ & $\begin{array}{l}\text { - elaboração da idéia geral da cena, } \\
\text { com o seu começo, o meio e o seu } \\
\text { fim. }\end{array}$ \\
\hline MOVIMENTO & $\begin{array}{l}\text { - A definição das ações motoras que } \\
\text { cada personagem irá realizar. }\end{array}$ & $\begin{array}{l}\text { - definir os tipos de movimentos a } \\
\text { serem realizados, de acordo com os } \\
\text { objetivos e as intenções da cena. }\end{array}$ \\
\hline COREOGRAFIA & $\begin{array}{l}\text { - A definição ou organização das } \\
\text { ações da cena no espaço e no tempo } \\
\text { (seqüência, duração, forma...). }\end{array}$ & $\begin{array}{l}\text { - estabelecer a sequiência e duração } \\
\text { de cada parte da cena } \\
\text { - estabelecer a disposição dos } \\
\text { personagens na cena }\end{array}$ \\
\hline ÂNGULO DE VISÃO & $\begin{array}{l}\text { A posição da cena no espaço de } \\
\text { modo a evidenciar o objeto que se } \\
\text { quer mostrar para o público. }\end{array}$ & $\begin{array}{l}\text { - estabelecer a posição das pessoas e } \\
\text { objetos da cena favorecendo a visão } \\
\text { do público para o objeto que se quer } \\
\text { mostrar e de acordo com a intenção } \\
\text { da cena. } \\
\text {-organização no espaço do palco (do } \\
\text { lado, atrás, na frente) } \\
\text { - organização com relação à frente do } \\
\text { palco (posicionar-se de frente, de } \\
\text { lado, de costas), a depender do } \\
\text { objetivo da cena. }\end{array}$ \\
\hline MÚSICA & $\begin{array}{l}\text {-os sons, ritmos e melodias que } \\
\text { contribuem para concretizar a } \\
\text { intencionalidade da cena. }\end{array}$ & $\begin{array}{l}\text { - criar uma sonoridade que contribua } \\
\text { para concretizar a intencionalidade } \\
\text { pretendida com a cena. }\end{array}$ \\
\hline ACESSÓRIOS & $\begin{array}{l}\text { - as roupas, cenários e maquiagens } \\
\text { que ajudam a materializar a intenção } \\
\text { da cena. }\end{array}$ & $\begin{array}{l}\text { - criar estímulos visuais para o } \\
\text { público (roupas, cenários } \\
\text { maquiagens) que contribuam para } \\
\text { que eles se relacionem com a } \\
\text { intencionalidade da cena. }\end{array}$ \\
\hline NARRADOR & $\begin{array}{l}\text { - criar momentos intencionais de } \\
\text { comunicação com o público }\end{array}$ & $\begin{array}{l}\text { - buscar instigar a relação do público } \\
\text { com a cena. } \\
\text { - criar momentos de comunicação } \\
\text { direta do personagem com o público } \\
\text { (descrever a cena, fazer perguntas...) } \\
\text { - criar momentos de comunicação } \\
\text { indireta (linguagem não verbal): ex } \\
\text { olhar para o público para arrancar } \\
\text { aplausos. }\end{array}$ \\
\hline
\end{tabular}

Quadro 7: As abstrações conceituais para o trabalho de ensino com a atividade circense.

Todas as discussões feitas até aqui, sobre a definição da unidade fundamental do objeto, as abstrações conceituais e o modo geral de ação historicamente elaborado nesse 
objeto, fazem parte do movimento de caracterização do circo enquanto uma atividade estético-artística. De certo modo, trata-se da primeira tarefa e das primeiras ações do docente quando ele inicia o processo de organização de uma atividade de estudo. Para organizar, efetivamente, essa atividade de estudo, é preciso transformar o objeto circo em um objeto de estudo. Ou seja, reconstituir a atividade original em forma de atividade de aprendizagem, evidenciando ainda mais o modo geral de ação presente no objeto, tornando-o o eixo central das tarefas de aprendizagem e de ensino, bem como elaborando as ações de aprendizagem dos estudantes e as ações de ensino dos docentes.

Assim, caracterizar um objeto em sua essência representa somente o ponto de partida das ações docentes no processo de organização de uma atividade de estudo. Iremos, agora, descrever e analisar o plano de ensino que elaboramos para o nosso experimento didático, bem como as ações docentes e discentes que se deram no decorrer das aulas.

\subsubsection{O plano de ensino}

O processo de elaboração do plano de ensino para o nosso experimento didático com o circo passou por duas etapas. Na primeira (planejamento I), elaboramos o planejamento sem ter em mãos as condições objetivas de ensino que teríamos (dentre elas, e como principal nesse caso, a quantidade de horas para as atividades). Na segunda (planejamento II), fizemos uma adaptação do Planejamento I à quantidade de aulas e de horas que teríamos para trabalhar com os estudantes.

Por essa razão, tanto o planejamento I, quanto o planejamento II, partiram de uma mesma estrutura de organização do ensino, estrutura essa exposta no quadro abaixo:

\section{ETAPAS PARA A ORGANIZAÇÃO DO ENSINO}

a) busca da unidade fundamental do objeto de estudo (a síntese e o modo geral de ação) e de seus elementos essenciais (as abstrações conceituais).

b) reconstituição da atividade e do objeto em forma de atividade de estudo/objeto de estudo: transformação das unidades e das 


\begin{tabular}{l}
\hline abstrações em ações de aprendizagem e ações de ensino. \\
\hline c) elaboração do percurso geral do estudante: os problemas de \\
aprendizagem, as situações desencadeadoras de ensino e as tarefas \\
de aprendizagem.
\end{tabular}

Quadro 8: Etapas para a organização do ensino pelo educador.

O modo geral de ação encontrado no circo - a composição dos elementos de criação em cenas e a partir da realidade circense - deveria constituir-se na síntese a ser alcançada pelos estudantes (que se apropriariam desse mesmo modo de ação) e na unidade fundamental do objeto de estudo.

Para os educadores, a composição dos elementos de criação em cenas constitui-se como a referência ou eixo de toda a organização do ensino e de suas ações junto aos estudantes. Para os educandos, a composição dos elementos em cenas constitui-se no ponto de chegada do ensino, ou seja, na criação de uma nova conduta no que se refere ao processo de criação/apreciação de um objeto artístico.

As abstrações conceituais, ao indicarem ou orientarem os modos de ação dos educandos no processo de solução das tarefas de aprendizagem, devem fazer parte desde o início do trabalho dos estudantes. Os estudantes se aproximam do objeto a partir do princípio geral do processo de apropriação de um conhecimento, caminhando do abstrato ao concreto (DAVYDOV, 1982; KOPNIN, 1978), ou seja, do estudo dos elementos de criação e seus conceitos para a criação efetiva de cenas com os personagens circenses.

Deste modo, e num primeiro momento, o processo de criação de cenas serviria como um modelo para o estudo dos elementos de criação (ações com as abstrações conceituais). Criar uma cena com os personagens circenses se constituiria, já, como um problema específico a ser resolvido pelo modo geral de ação estudado: composição da intencionalidade, ângulo de visão, coreografia etc, em uma cena circense.

Cada novo conceito, cada elemento de criação, indica ou orienta as ações dos educandos: explicita um objeto de ação e indica um modo de agir ${ }^{39}$. Portanto, a definição conceitual sintetiza esse modo geral de ação e apropriar-se do conceito significa não só apropriar-se dos significados e da sua definição, mas, sobretudo, daquele modo geral de ação sintetizado no conceito.

\footnotetext{
${ }^{39}$ Ver quadro 7 sobre as abstrações e modos de ação para cada elemento de criação circense.
} 
Apresentamos no quadro 9 o plano de ensino I. Esse planejamento geral cria um primeiro esboço de todo o percurso de ensino e de aprendizagem necessários para o estudo da atividade circense. Contudo, para a sua efetivação se faz necessário esmiuçar tanto as tarefas de aprendizagem, que no planejamento estão expostas apenas em seus aspectos gerais, como, e principalmente, as ações de ensino dos docentes (que colaborarão para a materialização da própria atividade de estudo) e das ações de aprendizagem dos educandos (que permitirão a apropriação do objeto de estudo por eles).

Deste modo, no quadro 9 (Planejamento I), podemos ter uma dimensão do percurso geral da atividade de estudo com o circo, bem como da estrutura de sua organização. No quadro 10 (Ações de ensino e aprendizagem), podemos analisar as ações concretas de ensino e de aprendizagem planejadas por nós ${ }^{40}$.

\begin{tabular}{|c|c|}
\hline & PLANEJAMENTO I \\
\hline ORGANIZAÇÃO PEI & AGÓGICA GERAL DO ESTUDO DO CIRCO \\
\hline TIPOS DE TRABALHOS & TAREFAS GERAIS DE APRENDIZAGEM \\
\hline $\begin{array}{l}\text { I) trabalho com os } \\
\text { elementos de criação de } \\
\text { cenas circenses: conceitos } \\
\text { e modos de ação. }\end{array}$ & $\begin{array}{l}\text { a) resolução de tarefas gerais de criação de cenas, que } \\
\text { coloquem como problema para o estudante (e objeto de } \\
\text { suas ações) um dos elementos de criação; } \\
\text { b) movimento de análise e síntese dos conceitos a partir } \\
\text { das definições conceituais e das cenas criadas } \\
\text { - síntese do modo geral de ação para a criação de } \\
\text { cenas (circenses). }\end{array}$ \\
\hline $\begin{array}{l}\text { II) trabalho com a } \\
\text { composição de cenas } \\
\text { circenses. }\end{array}$ & $\begin{array}{l}\text { a) estudo das características dos personagens (os } \\
\text { movimentos e a suas possíveis intencionalidades) } \\
\text { b) criação de cenas com os personagens a partir, ou tendo } \\
\text { por referência, o modo geral de ação (os conceitos dos } \\
\text { elementos de criação das cenas estudados); } \\
\text { c) criação de cenas com ajuda de uma ficha guia } \\
\text { (anexo I). }\end{array}$ \\
\hline $\begin{array}{l}\text { III) trabalho com a criação } \\
\text { de um espetáculo de circo. }\end{array}$ & $\begin{array}{l}\text { a) criação de cenas com os personagens circenses a partir } \\
\text { do modo geral de ação estudado; } \\
\text { b) composição das cenas criadas em um mesmo } \\
\text { espetáculo (relações entre as cenas). }\end{array}$ \\
\hline
\end{tabular}

Quadro 9: Planejamento geral da unidade didática do circo.

\footnotetext{
${ }^{40}$ A exposição dos planos de ensino (quadros 9 e 10) representa, já, um movimento de sistematização dos planos "originais", isto é, um movimento de análise e síntese do pesquisador no processo de exposição dos resultados da pesquisa.
} 
Deste planejamento geral, elaboramos as ações específicas de ensino e de aprendizagem para o trabalho pedagógico com a unidade didática do circo (quadro 10).

\begin{tabular}{|c|c|c|}
\hline \multicolumn{3}{|c|}{$\begin{array}{l}\text { TAREFAS DE APRENDIZAGEM, AÇÕES DO EDUCADOR } \\
\text { E DO EDUCANDO NA ATIVIDADE DE CIRCO }\end{array}$} \\
\hline \multirow{3}{*}{$\begin{array}{l}\text { Tarefas de } \\
\text { aprendizagem }\end{array}$} & Ações dos educandos & Ações do educador \\
\hline & & $\begin{array}{l}\text { A1- estudo da atividade circense, } \\
\text { buscando definir a sua unidade } \\
\text { fundamental e as suas abstrações } \\
\text { conceituais. }\end{array}$ \\
\hline & & $\begin{array}{l}\text { A2- criação do objeto de estudo } \\
\text { circo e organização das tarefas de } \\
\text { aprendizagem e das ações de } \\
\text { aprendizagem (esboço de todo o } \\
\text { percurso da aprendizagem para a } \\
\text { apropriação do objeto) }\end{array}$ \\
\hline $\begin{array}{l}\text { a) Análise de um } \\
\text { espetáculo circense } \\
\text { (vídeo), elencando os } \\
\text { elementos que são } \\
\text { importantes para a } \\
\text { construção de um } \\
\text { espetáculo e as } \\
\text { intenções de cada } \\
\text { personagem visto. }\end{array}$ & $\begin{array}{l}\text { A1- Análise inicial do objeto de } \\
\text { estudo: } \\
\quad \text { - explicitação dos elementos } \\
\text { circenses que já conhecem } \\
\text { (conhecimentos prévios dos } \\
\text { educandos); } \\
\quad \text { - análise dos elementos } \\
\text { presentes no espetáculo de } \\
\text { circo assistido (levantamento } \\
\text { espontâneo dos elementos; as } \\
\text { impressões dos estudantes a } \\
\text { partir do vídeo) } \\
\quad \text { - análise das sensações que } \\
\text { os personagens transmitiram } \\
\text { ou pretendiam transmitir para } \\
\text { o público }\end{array}$ & $\begin{array}{l}\text { A3- Desencadear a análise inicial } \\
\text { do objeto de estudo. } \\
\quad \text { - elaboração de perguntas guias } \\
\text { para a análise dos elementos de } \\
\text { criação e das intencionalidades dos } \\
\text { personagens. } \\
\text { - síntese inicial das idéias dos } \\
\text { educandos sobre os elementos de } \\
\text { criação das cenas e sobre as } \\
\text { intencionalidades dos personagens } \\
\text { (cômica, apreensiva, bela) }\end{array}$ \\
\hline $\begin{array}{l}\text { b) Resolução de } \\
\text { tarefas de } \\
\text { aprendizagem com } \\
\text { base no modo geral } \\
\text { de ação } \\
\text { disponibilizado pelo } \\
\text { educador: criação de } \\
\text { cenas “modelo” para } \\
\text { o estudo dos } \\
\text { elementos de criação } \\
\text { de cenas. }\end{array}$ & $\begin{array}{l}\text { A2- Criar algumas cenas com } \\
\text { caixas vazias (transportando } \\
\text { as caixas) de acordo com uma } \\
\text { intencionalidade definida } \\
\text { (cômica, bela, apreensiva) } \\
\text { e/ou de acordo com os demais } \\
\text { elementos de criação } \\
\text { (movimento, ângulo de visão, } \\
\text { coreografia). } \\
\text { A3- Analisar a partir das } \\
\text { cenas criadas os modos de } \\
\text { ação presentes em cada } \\
\text { elemento de criação e suas }\end{array}$ & $\begin{array}{l}\text { A4- Disponibilizar modelos de } \\
\text { cenas com os elementos de criação } \\
\text { e/ou coordenar o processo de sua } \\
\text { criação. } \\
\text { - Criar problema de } \\
\text { aprendizagem, ressaltando o modo } \\
\text { geral de ação (a orientação) para a } \\
\text { resolução das tarefas. Desencadear } \\
\text { situaçôes onde os educandos } \\
\text { operem com as abstrações } \\
\text { conceituais. } \\
\text { A5- sintetizar os elementos de } \\
\text { criação em um modelo (ficha } \\
\text { orientadora para a criação de }\end{array}$ \\
\hline
\end{tabular}




\begin{tabular}{|c|c|c|}
\hline & sínteses conceituais & cenas) \\
\hline $\begin{array}{l}\text { c) criação de cenas } \\
\text { com os personagens } \\
\text { circenses (estudo do } \\
\text { modo geral de ação } \\
\text { de criação de cenas } \\
\text { na atividade circense) }\end{array}$ & $\begin{array}{l}\text { A4- Estudo das características } \\
\text { de alguns personagens circenses } \\
\text { - análise dos movimentos } \\
\text { que o personagem executa e das } \\
\text { dicas para sua execução. } \\
\text { - vivência dos movimentos } \\
\text { - análise das possíveis } \\
\text { intencionalidades do } \\
\text { personagem numa cena (cômico, } \\
\text { belo, suspense) } \\
\text { A5- Criação de cenas com os } \\
\text { personagens, a partir do modo } \\
\text { geral de ação estudado } \\
\text { (composição dos elementos em } \\
\text { uma cena de circo). } \\
\text { A6- Análise das cenas criadas } \\
\text { pelos colegas, com base nos } \\
\text { elementos estuddados. }\end{array}$ & $\begin{array}{l}\text { A6- organização/sistematização } \\
\text { dos personagens a serem } \\
\text { estudados, explicitando as dicas } \\
\text { para a execução dos movimentos } \\
\text { (uso de modelos gráficos e verbais) } \\
\text { e as intenções dos personagens } \\
\text { (uso de modelos de cenas com um } \\
\text { mesmo personagem, criando cenas } \\
\text { com intenções distintas). } \\
\text { A7- Auxiliar o processo de } \\
\text { criação de cenas ainda como um } \\
\text { meio para estudar o modo de } \\
\text { geral ação de criação de uma } \\
\text { cena. } \\
\text { - indicação sobre o uso da } \\
\text { ficha orientadora para a criação } \\
\text { de cenas (anexo I). }\end{array}$ \\
\hline $\begin{array}{l}\text { d)criação do } \\
\text { espetáculo de circo }\end{array}$ & 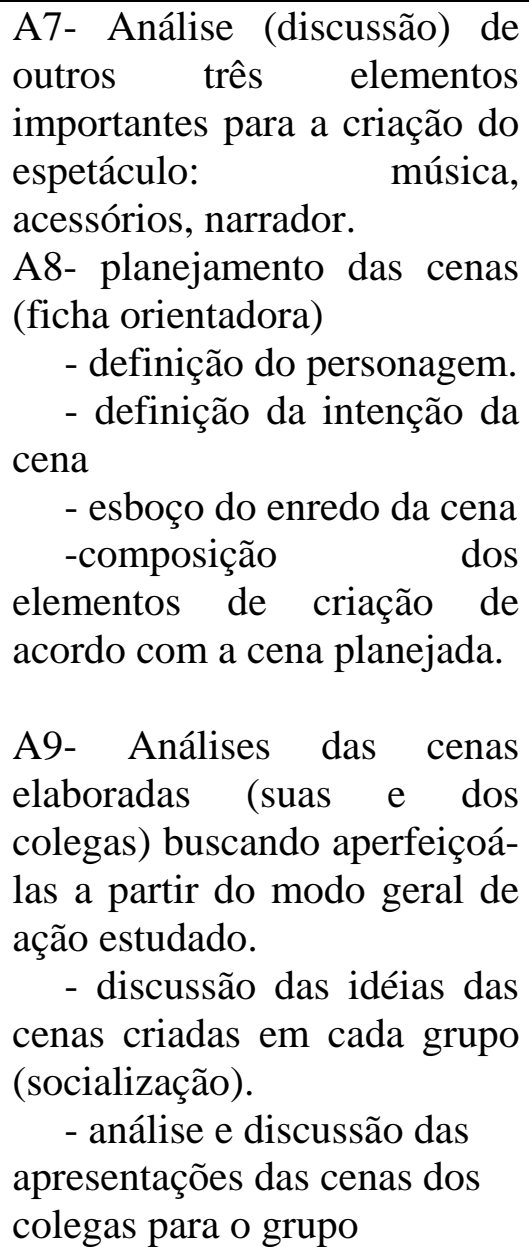 & $\begin{array}{l}\text { A8- Introduzir a discussão da } \\
\text { diferença entre a criação de } \\
\text { cenas de circo e do espetáculo } \\
\text { propriamente dito } \\
\text {-apresentação de outros três } \\
\text { elementos importantes para a } \\
\text { criação do espetáculo: música, } \\
\text { acessórios, narrador. } \\
\text { A9- Auxiliar as ações dos } \\
\text { educandos nos processos de } \\
\text { criação e análise das cenas } \\
\text { - tornar evidente os modos } \\
\text { gerais de ação necessários e/ou } \\
\text { utilizados por eles. }\end{array}$ \\
\hline
\end{tabular}

Quadro 10: Tarefas de aprendizagem, ações docentes e ações discentes na unidade didática do circo. 
Um plano de ensino caracteriza-se por representar uma orientação geral, porém suficiente, para as ações concretas de ensino e aprendizagem. Por mais esmiuçadas que estejam as tarefas de aprendizagem e as ações pedagógicas decorrentes delas, o planejamento de uma unidade de ensino aborda sempre os aspectos mais gerais para a efetivação do ensino para um determinado objeto de estudo. Porém, esses aspectos mais gerais, representam os aspectos essenciais daquela atividade de estudo, as características necessárias e suficientes para a organização efetiva do ensino. Deste modo, o plano de ensino, por mais especificado que esteja (e o deve estar) não nos aponta diretamente para os planos de aula. Estes são também esboçados, aula a aula, a partir do plano de ensino, mas são continuamente alterados, a depender das relações concretas e do percurso efetivo de ensino e de aprendizagem.

Em nosso experimento didático, o Planejamento I e as ações de ensino e aprendizagem decorrentes dele, serviram de base para a elaboração do Planejamento II. A diferença fundamental e mais relevante entre o planejamento I e o II está na quantidade e, possivelmente, a qualidade do trabalho, com o estudo das abstrações conceituais. Por uma questão de disponibilidade de tempo, o estudo previsto com os elementos circenses e os seus conceitos (ver tarefas “b” e “c” do quadro 10) foi bastante reduzido em nosso experimento didático. O que para nós deveria, em termos ideais, ocupar quase metade do curso, ocupou cerca de um quinto do mesmo. Esta condição objetiva para a organização do ensino não representou uma ruptura com os nossos objetivos de pesquisa nem com o percurso de aprendizagem dos estudantes. Podemos destacar dois fatores centrais para isso.

Em primeiro lugar, ao termos como referência para as análises as ações ideais de ensino e aprendizagem, pudemos identificar em nossos resultados (nas ações dos docentes e nas aprendizagens dos estudantes) não só aquilo que efetivamente foram em nosso experimento, mas, também, aquilo que poderiam ter sido. Neste sentido, trabalhamos com a dimensão do real efetivo e do real possível/desejável, o que pareceu nos aproximar ainda mais de nosso objeto de estudo (o processo de organização do ensino para a formação do pensamento estético-artístico).

Em segundo lugar, o modo geral de ação da atividade circense conseguiu se configurar, efetivamente, como o eixo do trabalho pedagógico. Ainda que o estudo das abstrações conceituais (os elementos de criação das cenas) tenha sido reduzido e, em certa medida, insuficiente pensando em termos ideais de ensino, o fato de termos conseguido mantê-los presentes e em evidência durante todas as tarefas de criação das cenas, fez com que o modo geral de ação da atividade circense estivesse presente como objeto de estudo dos educandos. 
Possivelmente, se tivéssemos conseguido efetivar o ensino com o estudo das abstrações conceituais conforme previsto no planejamento, obteríamos outras qualidades de ensino e de aprendizagem, ou mais bem, outras possibilidades de análises desses percursos. Contudo, consideramos que o ensino real que tivemos não nos afastou da análise do processo de organização do ensino para a formação do pensamento estético-artístico.

Não iremos, aqui, apresentar e analisar cada uma das aulas realizadas. Iremos seguir nossa análise do planejamento e das ações docentes, a partir de episódios de ensino e de aprendizagem selecionados e que problematizem aspectos específicos e fundamentais relacionados ao ensino e ocorridos em nosso experimento didático.

Sintetizando o processo de elaboração do plano de ensino

I) O processo de elaboração de uma atividade de ensino começa pelo processo de explicitação da unidade fundamental do objeto a ser ensinado, ou seja, pela explicitação das características necessárias e suficientes do objeto, que nos permite compreendê-lo em sua essência. A unidade fundamental de um objeto é importante tanto para a compreensão da essência deste objeto, quanto para a organização de uma atividade de ensino;

II) A determinação da unidade fundamental de um objeto não é arbitrária. A unidade fundamental existe objetivamente na realidade, na forma de relações historicamente estabelecidas entre esse objeto e a realidade e, assim, não precisa e não pode ser recriada a cada instante e por cada pessoa, mas, antes, precisa ser revelada;

III) Para a explicitação da unidade fundamental de um objeto é preciso separar nele aquilo que é a sua essência daquilo que é a sua aparência. É preciso elencar os elementos que compõe o objeto e, sobretudo, as relações fundamentais entre esses elementos;

IV) A unidade fundamental do objeto assume o papel de orientador da atividade de ensino. A determinação da essência do objeto, de seus conceitos fundamentais, torna-se uma referência para a organização das ações de ensino dos educadores e das ações de aprendizagem dos educandos. 


\subsection{Análise dos Episódios de Ensino e aprendizagem.}

Os episódios de ensino e aprendizagem foram estruturados conforme demonstra o quadro a seguir:

\begin{tabular}{|c|c|c|}
\hline \multicolumn{2}{|c|}{$\begin{array}{c}\text { ELEMENTOS COMPONENTES DOS } \\
\text { EPISÓDIOS }\end{array}$} & DESCRIÇÃO \\
\hline \multicolumn{2}{|c|}{ Título do episódio } & $\begin{array}{l}\text { Sintetiza o tema geral a ser discutido no } \\
\text { episódio. }\end{array}$ \\
\hline \multicolumn{2}{|l|}{ Cenas } & $\begin{array}{l}\text { Representam os momentos particulares } \\
\text { dentro do episódio; as situações ou conjunto } \\
\text { de situações que nos permitem visualizar o } \\
\text { fenômeno a ser analisado. }\end{array}$ \\
\hline \multicolumn{2}{|c|}{ Narração das cenas } & Descrição geral da cena. \\
\hline \multicolumn{2}{|l|}{ Cenários } & $\begin{array}{l}\text { Descrição do ambiente e/ou antecedentes de } \\
\text { uma dada situação presente na cena; }\end{array}$ \\
\hline \multirow[t]{3}{*}{$\begin{array}{l}\text { Sujeitos da } \\
\text { pesquisa }\end{array}$} & Professores & $\begin{array}{l}\text { São identificados por algarismo romanos: } \\
\text { Prof I, II, III, IV. }\end{array}$ \\
\hline & Estudantes & $\begin{array}{l}\text { São identificados por nomes. (Os nomes } \\
\text { reais das crianças foram substituídos por } \\
\text { outros, escolhidos por nós). }\end{array}$ \\
\hline & Narrador & $\begin{array}{l}\text { Trata-se de um parecer do pesquisador a } \\
\text { respeito de algum aspecto da cena. }\end{array}$ \\
\hline \multicolumn{2}{|c|}{ Transcrições } & $\begin{array}{l}\text { As transcrições literais das falas dos sujeitos } \\
\text { estão identificadas entre aspas. Quando } \\
\text { queremos evidenciar uma dessas falas, as } \\
\text { negritamos. }\end{array}$ \\
\hline
\end{tabular}

Quadro 11: Os elementos componentes dos episódios de ensino e aprendizagem

Muitas vezes as cenas que compõe um episódio aconteceram em momentos distintos de uma mesma aula e/ou em aulas diferentes. Para facilitar a leitura dos dados, optamos por não identificar o tempo em que se deu cada uma das cenas (referente ao tempo de gravação dos vídeos, dispostos em nove dvds), indicando apenas as aulas em que ocorreram. 


\subsubsection{Os Episódios de Ensino.}

Episódio 1: Intervenções nas ações práticas dos educandos

Episódio 2: Intervenções nas ações de estudo

Episódio 3: Estrutura da organização do ensino

Episódio 4: Intervenção dos educadores no processo de criação das cenas

\section{Episódio 1: Intervenções nas ações práticas dos educandos}

Unidade conceitual de análise: Atividade orientadora de ensino.

\section{CENA 1: quando as intervenções estão além da ZDP do estudante.}

narração da cena:

Durante os momentos de trabalho em que os estudantes apresentavam suas cenas para os colegas e para os educadores (aulas 6 e 8), muitas das falas dos professores são direcionadas diretamente para que ocorram mudanças nas ações práticas dos educandos. As mudanças almejadas estão sempre relacionadas a um ou outro elemento de criação das cenas, mas acabam não resultando numa mudança consciente nas ações dos educandos e nem colocam tais mudanças como objeto de reflexão dos estudantes.

\section{cenário um:}

Cena dos mágicos (aula 6): os mágicos começam o seu primeiro número de mágicas ("mágica das moedas"). O estudante Rodrigo está um pouco distante do público. Ele inicia a mágica e o público não consegue ver nem entender o que ele está fazendo.

Prof I: "Rodrigo, fala alto o que você está fazendo"

Prof II: "Fala pro público"

Rodrigo: "Como assim?”

Prof II: "o que você está fazendo...”

Narrador: O estudante não compreende a fala das professoras. Um outro estudante, também mágico, ajuda:

João: “ele está colocando as moedas...”"

\section{cenário dois:}

Cena do malabarista (aula 6): Luis começa a sua cena do malabarismo. Em um determinado momento de sua apresentação, ele fica de costas para o público, impedindo que este veja seus movimentos.

Prof II: “A frente do palco Luis..."

Narrador: Ele tenta ficar de frente, mas a cada nova seqüência de movimentos, posiciona-se novamente de costas para o público.

cenário três:

Cena dos diabolôs (aula 8): um dos estudantes que faz a cena permanece quase o 
tempo inteiro de costas para o público enquanto realiza seus movimentos com o diabolô. $\mathrm{O}$ público não consegue acompanhar a cena e algumas crianças reclamam. Os educadores também lembram o estudante sobre sua posição.

Prof IV: "Rui olha o público, Rui."

Prof II: "Está de costas..."

Narrador: O estudante não consegue corrigir a sua posição no palco.

\section{cenário quatro:}

Cena dos palhaços diabolôs (aula 6): os palhaços fazem sua cena, demarcando bem as intenções que tinham com ela. Em um determinado momento, começam a repetir as ações existentes na cena diversas vezes e não conseguem encaminhar o seu final.

Prof II: "Vamos pensar como é que encaminha o final da cena meninos? O que que vocês tinham pensado?"

Narrador: O professor repete essa fala mais três vezes, em cerca de três minutos, até que eles terminam a cena.

\section{CENA 2: intervenções como uma forma de lembrança de um conceito}

\section{narração da cena:}

Neste mesmo trabalho de apresentação das cenas e nestes mesmos tipos de intervenções dos educadores (falas pontuais durante as apresentações $e$ voltadas a mudanças diretas nas ações práticas dos estudantes), observamos um outro papel dessas falas: servem como um lembrete para a criança de um modo de ação já conhecido e relativamente dominado por ela.

\section{cenário um:}

Apresentação dos acrobatas com a pirâmide (aula 6). Os três estudantes que farão a cena entram. Bianca prepara a pirâmide de costas para o público.

Prof II: “oh, olha onde está o palco..."

Bianca (virando-se) “ah, é aqui!”

\section{cenário dois:}

Apresentação dos equilibristas com bastão (aula 6). Os meninos realizam a cena e ela começa a ficar repetitiva e demorada.

\section{Prof II: “Vamos pensar como é que vai ser esse final dessa cena, então? Pra} encaminhar....”

Narrador: Mesmo com a fala da educadora a cena não parece encaminhar-se para um final. A educadora chama o estudante Vinícius, que estava apresentando a cena, e pede que ele ajude os meninos a encaminhar o final da cena. Vinícius, imediatamente, cochicha no ouvido dos outros dois estudantes algo relativo à finalização da cena. No sinal estabelecido por Vinícius, os três caem no chão com os bastões e terminam a cena. 
As diferentes cenas selecionadas para esse episódio têm como característica comum o fato de representarem ações educativas que intervêm diretamente nas ações práticas dos estudantes. Embora os elementos de criação estejam sempre presentes nessas falas (o ângulo de visão em um caso, o desenvolvimento da cena em outro, a narração em um terceiro), eles não desempenham, aqui, o papel de objeto para os educandos. As intervenções dos docentes nas cenas do presente episódio, ainda que se refiram aos elementos de criação, não buscam indicar ações de reflexão (análise e síntese) sobre os próprios elementos, mas do contrário, buscam modificar diretamente uma ação prática dos estudantes. Neste sentido, e nesses casos, o conceito não é objeto dos educandos.

Esse tipo de intervenção apresenta dois desdobramentos pedagógicos. Por um lado, as ações docentes podem servir como uma forma de recordação para os estudantes de conceitos que eles já tenham algum domínio. Trata-se de uma maneira de lembrar um modo de ação que ainda não está automatizado pelo estudante, mas que, de alguma forma, ele já tenha algum domínio. A cena dois do episódio apresenta duas situações em que isso acontece. Em uma, ao ser lembrada da sua posição em relação ao público/palco, a estudante prontamente modifica suas ações, corrigindo o seu erro: “ah, é aqui!” (cena 2, cenário 1). Na segunda situação, ao ser lembrado pela professora da necessidade de caracterizar o final da cena, o estudante dirigise para os seus colegas e combina um sinal para que terminem a cena conforme o planejado durante os ensaios (cena 2, cenário 2).

Em ambos os casos, os estudantes demonstram que, de alguma forma, estão caminhando na apropriação dos referidos conceitos e dos modos de ação decorrentes deles, ainda que não os tenham internalizado completamente. Quando a estudante diz “Ah, é aqui!”, demonstra que conhece a situação que está sendo problematizada pela educadora e é capaz de corrigir suas próprias ações; ela demonstra possuir uma generalização de um determinado modo de ação naquela situação. Bastava uma recordação, bastava fazê-la "focar a atenção” no elemento, para que pudesse encaminhar adequadamente a solução da tarefa.

Do ponto de vista do educador, quando o professor diz "Rui, olha o público, Rui" (cena 1, cenário 3), ele não espera que o estudante pense, naquele momento, sobre o conceito, analisando o modo geral de ação presente nele, mas que o estudante "fique de frente para o público”, isto é, que modifique sua ação prática, recorde uma resposta que, em outro momento, já havia construído.

Por outro lado, esse tipo de intervenção docente que age diretamente nas ações práticas dos estudantes, pode resultar ou em uma intervenção absolutamente ineficaz ou em uma intervenção que produza efeitos negativos na aprendizagem dos educandos. Se um 
estudante não domina minimamente o conceito a que o professor está se referindo a intervenção docente será nula. Dominar o conceito, como já dissemos, não é apenas saber seu nome e declarar seu significado, mas poder usá-lo como um mediador de suas ações, isto é, como uma referência para a ação na solução de uma tarefa. Assim, a não mudança nas ações (cena 1, cenários 1, 3 e 4) ou a declaração de completo desconhecimento do que o professor está propondo (caso do estudante que diz: “Como assim?”, cena 1, cenário 1), denota que esse tipo de intervenção docente não consegue contribuir para o processo de aprendizagem destes estudantes; as intervenções estão muito além do momento em que se encontram em seus percursos de aprendizagem. Não ajudam a criança, não servem como uma forma de colaboração para que se apropriem dos conhecimentos e modos de ação que estão sendo ensinados. Justamente por isso, trata-se de uma intervenção ineficaz do ponto de vista do desenvolvimento do estudante.

Como já mencionamos, para os estudantes que ainda não dominam os conceitos que estão sendo estudados, esse tipo de intervenção direta em suas ações práticas (em suas respostas), além de ineficaz, pode ser prejudicial para a aprendizagem dos estudantes. Paradoxalmente, isso ocorre, justamente, quando as intervenções dos educadores resultam em mudanças nas ações práticas dos educandos. A intervenção docente buscando modificar as ações práticas dos estudantes só faz sentido quando estes dominem suas próprias ações e estejam passando por um processo de automatização das mesmas, isto é, transformando as ações em operações conscientes (LEONTIEV, 1983). Se os estudantes não dominam suas ações e passam a “dominá-las” sem antes terem plena consciência das mesmas, sem as dominar voluntariamente, acabam criando ações mecanizadas ou formando “operações não conscientes” (LEONTIEV, 1983). Ou seja, antes mesmo de dominar uma determinada ação, de ser consciente desse "modo geral de ação", o educando passa a executar "adequadamente" a tarefa.

É possível fazer com que um estudante realize uma ou outra ação correta sem, contudo, fazê-los efetivamente dominar essas ações, isto é, sem que sejam conscientes das mesmas, que as utilizem como um meio de abstração e análise no processo de elaboração das cenas. Podemos, por exemplo, posicionar um estudante de forma correta no palco, fazê-los falar mais alto, reproduzir uma seqüência de cena engraçada etc, mas isso não quer dizer que este estudante consiga, voluntariamente e em outras situações, posicionar-se da melhor maneira possível para o público, falar no tom adequado e criar uma outra seqüência de cena engraçada. Quando o educador solicita, repetidas vezes, que o estudante Luis fique de frente para o palco, ele consegue fazer com que o educando mude a sua postura (cena 1 / cenário 2), 
mas, por si só, o estudante não consegue posicionar-se da melhor maneira possível; essa necessidade ainda não se configura como uma necessidade para ele.

É neste sentido, que a intervenção docente pode ter um efeito negativo na aprendizagem dos estudantes: eles parecem dominar o conceito porque são capazes de atingir a resposta esperada, contudo eles não se apropriaram da generalização contida no conceito e não são capazes, portanto, de agirem adequadamente em outras situações nas quais não foram treinados.

Não queremos dizer com isso que uma única intervenção desse tipo possa resultar na formação de uma ação não consciente por parte do educando, mas sim pontuar a possibilidade de obtermos esses tipos de resultados com um ensino que esteja voltado, conscientemente ou não, mais para o domínio das operações, (para a resolução de tarefas práticas, cujos resultados específicos importam mais do que a apropriação do modo geral de ação), do que para o domínio consciente das ações por parte dos educandos.

Ainda que possamos isolar esse tipo de intervenção docente que age diretamente nas ações práticas dos educandos, analisando-as e tecendo considerações sobre seu papel e possíveis efeitos pedagógicos, não podemos tomar tais ações educativas como ações em si mesmas, isoladas do processo de ensino e aprendizagem. Intervenções pontuais, nas ações práticas dos educados, podem (e em alguns casos devem) fazer parte do processo educativo como um momento do trabalho sendo, inclusive, bastante benéficas (caso da cena 2, em que desempenham um papel de recordação para os estudantes). De todo modo, trata-se de um tipo de intervenção que acompanha (e deve acompanhar) outros tipos de intervenções docentes, que estejam voltadas para as ações de estudo dos educandos, caracterizadas por um processo explícito e intencional de apropriação dos conceitos.

\section{Episódio 2: Intervenções nas ações de estudo.}

Unidade conceitual de análise: Atividade orientadora de ensino.

\section{CENA 1: intervenções iniciais de problematização do conceito}

\section{narração da cena:}

Antes de iniciar um trabalho sistematizado com os conceitos, apresentando seus termos e definições, os educadores fizeram os estudantes pensarem sobre tais conceitos; trouxeram para o trabalho aqueles conhecimentos, análises e sínteses que os estudantes já tivessem formado em suas vidas cotidianas, mobilizando-os para 
novas reflexões.

cenário um:

Na aula 2, os educadores discutiam com as crianças sobre o papel ou a função do circo.

Prof II:“...Será que o circo sempre existiu....?

Crianças: "Não..."

Prof II: "Não? E por quê?"

Estudante 1: "Porque na idade da pedra não existia circo"

Estudante 2: "Se existisse circo sempre, os dinossauros iam ser palhaços!"

Prof II “...Há cinco mil anos atrás, as pessoas encontraram desenhos de pessoas fazendo acrobacias, fazendo malabarismos, pessoas fazendo movimentos ou cenas de palhaços... há bastante tempo atrás, não é? Mas nessa época, existia o circo... ou não? (...) Não existia o circo, mas já existiam esses movimentos. Por que será que os homens criaram esses movimentos se não tinha o circo?”

Crianças [vão sugerindo várias hipóteses]: "para ser dês-comum”;“para ser diferente dos outros"; "para impressionar”; "para ganhar dinheiro”; "para se divertir”; "para ficar feliz"; "para ficar famoso".

Narrador: Professora explica que esses movimentos estavam relacionados às atividades militares: os guerreiros precisavam ficar mais ágeis e fortes e muitos dos movimentos que hoje conhecemos no circo serviam como movimentos de treinamento para eles.

Prof II: “Aí só depois, que o homem conseguiu durante muito tempo desenvolver todos esses movimentos, é que daí ele criou o circo ou o espetáculo, que é o que a gente vai fazer aqui, não é?(...) por que os homens criaram o circo como espetáculo?”

Estudante 1: “...deixar as pessoas felizes”

Estudante 2: “... deixar as pessoas impressionadas”

Prof II: "Deixar as pessoas impressionadas... isso mesmo, Luis. Impressionadas, como? Com o quê?”

Estudantes: "Com a mágica”; "com as habilidades”, "com as contorções”

Prof II: “...Vamos fazer assim ó, vamos pensar nos personagens do circo e vamos pensar o que cada um transmitiu para vocês.”

Narrador: Começam uma discussão sobre alguns personagens do vídeo assistido em aula e o que eles as fizeram sentir. A professora, ao final, sintetiza a discussão das intencionalidades de criação:

Prof II: "Quando a gente for criar o nosso espetáculo e os artistas do circo que a gente viu na televisão, do circo que vocês viram na escola, a primeira coisa que vocês vão ter que pensar é o que que eles querem que o público perceba nessa apresentação. Será que o artista vai querer que o público dê risada, que ache engraçada? Se ele quiser isso ele vai ter que criar uma cena engraçada ou hilária."

Estudante: "ele vai ter que engolir espada!"

Prof I: “...esse caso que o Rodrigo está falando, de engolir espada, de colocar fogo, a gente vai achar engraçada ou a gente vai achar triste? Ou a gente vai ficar com medo, apreensivo de alguém se machucar?”

Rodrigo: "isso vai ser incrível, todo mundo vai gostar!"

Prof II: "Vai ser incrível Rodrigo, mas será que é a mesma coisa que o palhaço faz? É a mesma sensação?”

Narrador: Professora cita os outros dois tipos de cenas:

Prof: “...se a gente não quer fazer uma cena engraçada, a gente pode tentar criar uma cena que seja só bonita. E está faltando um terceiro tipo de cena para o nosso 
espetáculo, que não é nem bonita e nem engraçada...”

Estudante: "Incrível!"

Prof: "Uma cena incrível, muito bem João. (...)A gente vai querer com essa cena incrível que as pessoas sintam um certo receio (...) O objetivo do artista é que as pessoas fiquem um pouco apreensivas... deixar a pessoa com certo medo. Então a gente pode criar cenas de suspense.”

\section{cenário dois:}

Durante os trabalhos de criação de cenas com as caixas (aula 3), um dos estudantes prepara-se para mostrar a sua cena fingindo que a caixa estava pesada. Os estudantes estão sentados aleatoriamente no chão, cada um virado para um sentido. A educadora faz duas ações tendo em vista o elemento "ângulo de visão", ainda que não mencione esse termo diretamente para os educandos.

Prof II: "Rui, deixa eu dar uma idéia para você? Fica do lado da Bruna [educadora] para todo mundo te ver"

Narrador: Um pouco depois, outro grupo prepara-se para apresentar a sua cena. A educadora, antes de a cena começar, sugere que as crianças mudem de lugar, posicionando-as de frente para o grupo que irá apresentar a cena.

\section{CENA 2: organizando discussões sobre os elementos de criação (conceitos e modos de ação)}

\section{narração da cena:}

Em muitos momentos os educadores trabalham de forma mais explícita com os elementos de criação, fazendo com que estes (seus conceitos e modos de ação) sejam um objeto de reflexão dos estudantes. Estão presentes determinadas sínteses dos educadores e, sobretudo, perguntas destinadas à reflexão e sínteses dos conceitos pelos próprios educandos.

\section{cenário um:}

Após a apresentação de algumas cenas cômicas criadas "livremente" com as caixas (aula 3), uma educadora propõe uma das cenas como objeto de reflexão do grupo de estudantes. A cena criada consistia em colocar uma caixa em cima da cabeça e ficar se perguntando onde estava a caixa (fingindo que não sabia onde ela estava). Só quando a caixa caía da cabeça o estudante dizia “Ah, está aí!”. A educadora procura realizar com os estudantes um primeiro movimento de síntese sobre o que é e como é a criação de uma cena cômica:

Prof II: “tem graça isso para o público?”

Narrador: alguns estudantes dizem que sim, outros que não. Professor pergunta o porquê de cada opinião:

Vinícius [que achou a cena engraçada]: “porque ele ficou se fazendo de bobo...” Prof II: "O palhaço fica se fazendo de bobo para o público? Mas ele é bobo de verdade? Não... ele finge que é pros outros acharem graça”.

\section{cenário dois:}

Durante a apresentação dos conceitos de cada um dos elementos de criação das cenas 
(aula 4) uma das educadores traz um exemplo de uma cena para que as crianças analisassem o conceito de ângulo de visão, procurando relativizar a idéia de "ser de frente para o palco".

Prof II: "Posso dar um exemplo, também, para vocês pensarem? Vocês falaram da centopéia que a gente fez, não foi?... será que pro público ver [...] faz de conta que vocês são o público agora aí e a Bruna [professora] vai fazer uma centopéia. Será que é melhor a Bruna fazer a centopéia de frente para vocês ou de lado para vocês?

Luis: "De lado"

Algumas crianças: “de frente”

Prof II: "Por que de lado, Luis?"

Luis: "porque daí mostra mais coisa, mais as pessoas (...) vai mostrar quantas pessoas têm..."

Prof II: "Na centopéia é melhor ficar de lado pro público, geralmente, porque daí a gente consegue ver todo mundo, né? Consegue ver a centopéia direitinho. De frente a gente vai ver só uma pessoa andando (...) então depende da nossa intenção, o que que a gente quer mostrar pro público.”

\section{cenário três:}

Durante um dos trabalhos de avaliação das cenas criadas (aula 7) a educadora aproveita as discussões sobre as cenas engraçadas para problematizar o elemento intencionalidade na construção das cenas.

Narrador: O estudante Rui diz que todas as cenas realizadas foram engraçadas.

Prof II: “O contorcionista era uma cena engraçada também? $O$ que que o contorcionista tentou passar pra gente se não era de ser engraçado?

Luan: "Coisa elástica..."

Prof II: "Mas o que que elas queriam de intenção pro público? Que o público

ficasse admirado, que achasse bonito, que achasse engraçado...?

Luan: "Que achasse bonito."

Prof II "Que achasse bonito? Acha, Luan?"

Luan: "Colocar o pé na cabeça é muito difícil!”

Narrador: Thales fala que se as pessoas quebrassem a perna e tirassem os ossos para

fazer a cena ela não seria mais difícil e passaria a ser uma cena simples.

Prof I: "Mas isso não é uma cena bonita... é uma cena assustadora! Mas elas conseguiram passar? A intenção era fazer uma cena... elas estavam mostrando como elas conseguem isso que não é fácil pra todo mundo...”

Narrador: Uma das educadoras dá um exemplo do mesmo movimento (colocar o pé na cabeça) dentro de outra cena: colocar o pé na cabeça e ficar fazendo ou demonstrando esforço: fazer caretas e gritar de dor.

Prof II: "Elas fizeram de um jeito que parecia fácil”.

Narrador: O estudantes Luan tenta fazer o mesmo movimento e grita de "dor".

Prof II: "É, se a gente ficar gritando assim na hora vai parecer que é uma cena engraçada, né? [e não bonita]"

CENA 3: falas sínteses dos professores sobre os conceitos e modos de ação 
Algumas ações dos educadores eram explicitamente destinadas a realizar uma síntese dos conceitos que foram ou estavam sendo trabalhados. Geralmente as falas precediam discussões conjuntas com os educandos e partiam da análise de uma cena concreta elaborada por eles.

\section{cenário um:}

Durante um momento de trabalho em que se avaliavam as cenas produzidas pelos estudantes (aula 7), os professores realizam uma síntese sobre o conceito de "narração" em uma cena/espetáculo.

Prof I: “Teve alguma cena que não deu pra ver muito bem o movimento? Teve alguma hora que a gente não conseguiu ver muito bem o movimento?”

Rui : “...da mágica...”

João: "Fala sério..."

Rui: "É isso mesmo!"

Prof I: "Quais das mágicas, Rui?”

Rui: "A da moeda, que eu não entendi nada."

Narrador: Alguns estudantes começam a discutir que o problema foi porque a mágica foi mal feita e não porque não deu para ver.

Prof I: “...talvez seja possível a gente melhorar, fazer mais perfeita a mágica pra gente não perceber, ver o truque, mas explicar também é importante porque não dava pra gente ver e nem contar [as moedas] (...) o público não conseguia contar o que estava na mão dele. E como que ele podia explicar?”

Prof II: “...Mas então vamos pensar uma coisa aqui: a gente não tem um narrador? $O$ Luan, por enquanto. Muito bem. O mágico, ele vai ter que ser uma espécie de narrador... pra poder falar pro público o que que ele vai fazer, qual é aquela mágica [...] Então, todas as mágicas vocês vão ter que pensar como se fossem um narrador também. A mágica do óleo: se só colocar o óleo e o copo com o óleo, vai ficar sem graça, as pessoas não vão ver. Então vocês têm que criar um clima, que nem vocês colocaram lá no planejamento: de suspense... ' a gente vai fazer esse copo sumir dento dessa garrafa aqui’ [diz fazendo-se passar pelo mágico] João: "Não é suspense, é admiração"

Prof II: “Admiração, isso mesmo, é verdade... então vocês têm que pensar bem como que vão falar com o público. Certo?”

\section{cenário dois:}

Nessa mesma aula (aula 7), os educadores explicitam uma outra síntese, desta vez do elemento "ângulo de visão".

Prof I: "Então, além da gente pensar como a gente vai entrar, a gente tem que pensar onde a gente vai ficar no nosso palco [...] mas é importante a gente pensar mais ainda em como interagir com o público... olhar mais. Meninos do diabolô: fazer talvez de lado ou de um jeito que dê pro público ver que as varetas estão sem a linha. Ou quando for tropeçar, o que que tinha ali no meio, pro público ver bem a expressão de vocês.”

Prof II: (...) "Mas o, o que a Bruna [professora] está falando, lembra que a gente tinha que tentar planejar o nosso ângulo de visão? [...] tem que ver como é que a gente organiza a cena pro público ver direitinho aquilo que a gente quer passar. A centopéia: será que é legal ela ficar andando de lado... andar de frente pro público?”

Daniel: "de lado..." 
Prof II: “também acho que é melhor...”

Prof I: “O narrador... ele também tem que escolher um lado, uma frente pra se apresentar. Se agente fizer a pirâmide de lado, vai dar o mesmo efeito? Vai dar para perceber?"

Narrador: As crianças e os educadores iniciam uma discussão mostrando a relatividade da pergunta: depende da pirâmide. A pirâmide que o grupo dos acrobatas está fazendo é melhor ser feita de frente para o público.

Prof I: “... ver se a gente vai ficar de frente, de lado, se vai ficar na ponta do palco, se vai ficar lá na frente do palco e isso depende de quantas pessoas estão em cena, além do movimento [que vamos realiza]”

Este episódio aglutina cenas de intervenções docentes em que o foco das intervenções está, diretamente, nas ações de estudo dos educandos, isto é, nas suas ações com os conceitos propriamente ditos.

Dividimos este episódio em três momentos (cenas), que sintetizam diferentes formas de intervenções dos docentes no trabalho direcionado com os conceitos, criando ações de aprendizagem que busquem colocar os conceitos como o objeto de estudo dos educandos.

O primeiro momento (cena 1: intervenções iniciais de problematização do conceito), caracteriza-se, justamente, por ser um primeiro trabalho de aproximação das crianças com os conceitos que irão estudar. Neste momento do trabalho, os educadores não buscam, de forma explícita, sistematizar as definições conceituais (seus termos e modos de ação), mas iniciar com os educandos o processo de reflexão e o trabalho com o objeto de estudo.

Quando a educadora discute com as crianças o processo de constituição do circo como um espetáculo (cena 1/ cenário 1), ela explica a existência de três tipos de cenas no circo: cômica, bela e de suspense. O objetivo da educadora não é tanto o de sistematizar os conceitos das referidas intencionalidades, mas o de colocar as crianças em movimento para pensarem sobre estas intencionalidades das cenas: que existem diferentes intencionalidades no circo; que é possível associar os diferentes personagens existentes com os tipos de intenções da cena etc. Assim, o elemento intencionalidade da cena, embora seja trabalhado pela educadora a partir de seus termos (cena cômica, cena bela, cena apreensiva), não é trabalhado, neste momento, em sua dimensão conceitual. Os conceitos, propriamente ditos, os modos gerais de ação presentes em cada intencionalidade, não são objeto de ação nem dos educadores, nem dos educandos, embora os primeiros tenham estes conceitos como orientadores de suas ações desde o início de suas intervenções. 
Por um lado, poderíamos dizer que essa decisão atende a necessidade de se trabalhar com os conhecimentos prévios das crianças. Para iniciarmos o ensino de novos conceitos é, de fato, importante trabalharmos previamente com os conceitos que os educandos já trazem sobre o assunto, posto que é a partir destes que se formarão aqueles. Entretanto, os conceitos espontâneos ou empíricos constituem-se em ponto de partida do ensino somente para os educandos. Para o educador, os conceitos teóricos, as sínteses conceituais que os educandos deverão se apropriar ao final do ensino, devem ser o ponto de partida e a referência, do início ao fim do trabalho, para suas ações. Se assim não o for, o ensino pode ser organizado de tal modo que os conceitos empíricos sejam os objetos centrais de trabalho dos educandos em seus percursos de aprendizagem, o que nos coloca diante de um ensino pouco produtivo do ponto de vista do desenvolvimento do pensamento teórico nas crianças.

Neste sentido, ao analisarmos tarefas de aprendizagem em que os educandos trabalhem prioritariamente com os conceitos espontâneos, precisamos pontuar, em primeiro lugar, a relação dessa tarefa com as demais tarefas de aprendizagem (propostas no plano de ensino) e, em segundo lugar, a relação dos educadores com os conceitos teóricos.

O plano de ensino, a unidade didática do circo elaborada em nosso experimento didático, define que o trabalho com os elementos de criação das cenas constitui-se no eixo das ações de ensino e de aprendizagem (ver quadro 10). Tanto no cenário 1, quanto no cenário 2 deste episódio de ensino (ambos da cena 1), podemos identificar que os educadores tem em mente os conceitos teóricos, organizam suas ações a partir deles, ainda que não os verbalizem ou os transformem em objeto de ações para as crianças naquele momento. Quando a educadora sugere que os estudantes que vão apresentar uma cena mudem sua posição ou que as crianças que vão assistir fiquem em outro local (cena 1, cenário 2) ela tem clareza já que está organizando as crianças para o elemento “ângulo de visão”, mas não menciona nem o termo do conceito nem espera que aquele seja um momento para problematizá-lo; ela apenas sugere que as crianças se posicionem melhor, dizendo que, assim, poderão enxergar e/ou mostrar melhor a cena. Qual a razão dessa escolha? Por que não iniciar um trabalho mais sistemático naquele momento com o conceito ângulo de visão já que surgiram condições para tal?

Ocorre que no momento em que "surge” a necessidade de organizar o ângulo de visão para a apresentação de uma cena, os estudantes já estavam trabalhando (iniciando o trabalho) com um outro conceito: o de intencionalidade das cenas. Os educandos estavam em um processo de criação de cenas engraçadas, bonitas e de suspense, que eram apresentadas para os demais colegas e analisadas pelos educadores e educandos em seus objetivos ou intenções. 
O conceito de intencionalidade ocupava a atenção e a ação dos estudantes, tanto na criação das cenas quanto nas análises das mesmas. Introduzir outro conceito naquele momento poderia minimizar o trabalho tanto de um conceito, quanto do outro. Entretanto, e o que nos parece sumamente importante, é o fato da educadora demonstrar ter os conceitos teóricos como referência para suas ações. Ainda que ela não verbalize o conceito, ele está presente como um instrumento de seu trabalho. Ela organiza o ângulo de visão das crianças, sugere que mudem a posição em que estão "para verem melhor a cena”, mas ainda não coloca o conceito como objeto de ação/reflexão dos estudantes. E o faz de forma deliberada. Em outro momento do trabalho, o elemento ângulo de visão será proposto como o objeto de ação das crianças.

Assim, temos na cena 1 dois exemplos de trabalhos iniciais com os conceitos. A característica central deles é que embora os educadores tenham os conceitos teóricos presentes para si e organizem o ensino e suas ações tendo-os por base, eles não organizam, ainda, ações de aprendizagem explicitamente com os conceitos, isto é, os conceitos dos elementos de criação das cenas ainda não se configuram como objeto das ações dos educandos, embora já estejam presentes de forma indireta em suas tarefas.

O segundo momento do presente episódio (cena 2, “organizando discussões sobre os elementos de criação: conceitos e modos de ação"), aglutina situações cujas intervenções docentes buscam, justamente, colocar os conceitos como o objeto de ação dos educandos.

As intervenções docentes, tal qual na cena 1, procuram colocar os alunos em movimento no processo de reflexão/apropriação dos conceitos, mas desta vez de forma mais direta. As ações dos educadores, neste momento de trabalho, indicam ações com os conceitos para os educandos; propõem tarefas em que os educandos devam analisar o conceito (ou o modo geral de ação presente neste conceito) tornando-o, assim, seu objeto de estudo.

O elemento intencionalidade da cena (produzir cenas engraçadas, bonitas ou de suspense), foi o primeiro elemento conceitual trabalhado por nós. Organizamos uma aula (aula 3) onde os estudantes deveriam criar cenas com uma caixa (transportando-a e/ou manipulando-a) de acordo com um tema proposto pela professora ou um tema escolhido por eles. As criações eram sempre sugeridas e analisadas de acordo com uma das intencionalidades trabalhadas.

O início desse trabalho ocorreu de forma espontânea. Não orientamos as crianças, ainda, sobre os conceitos presentes em cada uma das intenções, isto é, os modos de ação indicados por cada intencionalidade. Essa sistematização dar-se-ia após algumas experimentações das crianças tentando criar cenas e após análises coletivas das cenas criadas. 
Ao final de uma seqüência de cenas engraçadas produzidas pelas crianças uma educadora retoma uma das cenas para que ela sirva como objeto de análise dos educandos (cena 2, cenário 1). A cena criada pelo estudante permite sintetizar um importante aspecto do conceito de cena engraçada, percebido e declarado pelo estudante Vinícius: “ele ficou se fazendo de bobo", e bastante explorado por nós ao longo das aulas. Neste momento, era sistematizado pela primeira vez o conceito de cena engraçada e o modo de ação para criá-la: é uma cena em que o personagem finge errar as coisas, finge-se de bobo ${ }^{41}$.

O fato de termos realizado essa síntese não significava que os educandos já tivessem se apropriado do conceito. Pelo contrário, continuavam num processo inicial de suas aprendizagens. Deste modo, a aula três marca o início desse processo de trabalho sistematizado com os conceitos, de sínteses e análises conceituais dos elementos de criação das cenas, que se mantiveram presentes (e deveriam manter-se mesmo) como eixo dos trabalhos em todas as aulas subseqüentes, principalmente durante os momentos de discussão e análise das cenas criadas.

No cenário 3 (cena 2), os educadores discutem com as crianças conceitos presentes numa cena cômica e numa cena bela. A cena das contorcionistas serve de material para a análise dos estudantes e os professores vão direcionando as discussões para que essa análise se dê a partir dos elementos de criação e de seus conceitos. Um mesmo movimento (colocar os pés na cabeça), que na cena das contorcionistas é feito de modo a transmitir para o público uma sensação de facilidade e desenvoltura na realização do movimento, criando uma cena bonita, é transformado por uma criança e por um educador em uma cena engraçada. A criança realiza o mesmo movimento e grita “de dor” durante a execução; o educador executa o movimento e faz caretas, demonstrando a dificuldade em sua realização. Nesses casos, o personagem demonstraria para o público não saber fazer o movimento; erraria ou exageraria nos gritos e caras de dor para criar uma cena engraçada. Mais uma vez, os modos de ação para a construção de uma cena engraçada são objeto de reflexão dos estudantes, assim como os modos de ação para a construção de uma cena bonita (demonstrar segurança e facilidade na execução dos movimentos).

Da mesma forma, quando a educadora propõe a reflexão sobre um movimento (a centopéia) para a análise do ângulo de visão (cena 2, cenário 2), vemos a organização de uma tarefa de reflexão e análise de uma cena, tendo como referência para essa análise um dos elementos de criação - o ângulo de visão - e os conceitos decorrentes dele. Essa tarefa

\footnotetext{
${ }^{41}$ Existe uma outra dimensão da cena engraçada, além do mencionado, que não aparece nessa primeira síntese e que foi pouco trabalhada ao longo das aulas: a caricaturização ou exacerbação de aspectos da realidade.
} 
concretiza uma idéia presente na unidade didática do circo, qual seja, a de propor tarefas de análise de cenas cujas soluções requeiram a utilização dos conceitos dos elementos de criação das cenas. Para analisarmos uma cena com relação ao ângulo de visão e para construirmos uma cena organizando conscientemente esse elemento, temos que ter em mente as seguintes sínteses conceituais: a) é preciso organizar a cena de modo a favorecer a visão do público naquilo que quero mostrar para ele; b) é possível organizar a cena de frente, de lado ou de costas para o público, a depender do objetivo que tenho com a cena.

Esses conceitos, como já dissemos em outros momentos, sintetizam um modo geral de ação na resolução da tarefa “organizar a visão do público para a cena” e, neste sentido, ao apropriar-se desse conceito, o educando amplia em quantidade e qualidade (já que passa a dominar a situação de forma mais consciente) as suas possibilidades de ação durante o processo de criação de uma cena.

Assim, as sínteses conceituais apresentadas pelos professores configuram-se como um instrumento para o trabalho dos educandos em seus processos de apropriação desses conceitos, isto é, de construção de suas próprias sínteses. Próprias, não no sentido de serem “da forma como cada estudante queira”, de serem produtos distintos para cada educando, mas no sentido de que os processos de apropriação do conceito (das sínteses) serão particulares para cada estudante. Cada um percorrerá um caminho próprio para chegar à apropriação do referido conceito. Os conceitos (significados) serão os mesmos, ainda que os sentidos sejam pessoais e distintos para cada um dos educandos.

Neste contexto, podemos situar a importância das falas em que os educadores sintetizam os conceitos de cada um dos elementos de criação das cenas (cena 3: "falas sínteses dos professores sobre os conceitos e modos de ação”). Ao definir um conceito, e inclusive ao repetir essa definição em diferentes momentos do trabalho, a ação do educador não procura fazer os estudantes assimilarem o conceito a partir de suas falas, o que é, de todo modo, impossível, já que o máximo que ele conseguiria é uma memorização do conceito por parte dos educandos. Ao definir um conceito e ao explicitar um modo de ação presente num conceito, o educador procura fornecer um material para as ações dos educandos com esse conceito. A definição constitui-se, muitas vezes, numa ajuda para as crianças em seus processos de análises e sínteses teóricas; um instrumento a mais para o seu pensamento.

A partir das discussões e análises das cenas criadas pelos estudantes, os professores buscam sistematizar as avaliações feitas, retomando o conceito de cada um dos elementos de criação. O elemento narração (cena 3, cenário 1), por exemplo, foi sintetizado pela educadora como uma forma explícita de interação com o público, fazendo com que este envolva-se mais 
com a cena. Neste sentido, a narração não precisava ficar restrita à "figura de um narrador", pelo contrário, poderia e até exigiria (caso dos mágicos) uma ação dos próprios personagens.

Do mesmo modo, o elemento ângulo de visão (cenário 2, cena 3), foi sintetizado pela educadora em seu modo de ação: “ver se a gente vai ficar de frente, de lado, se vai ficar na ponta do palco, se vai ficar lá na frente do palco e isso depende de quantas pessoas estão em cena, além do movimento [que vamos realizar]”.

Observamos, nessas situações, uma intenção explícita dos educadores em nomear os conceitos, seus termos e definições, deixando claro o elemento de criação que está sendo trabalhado. Procuram, assim, criar momentos de reflexões para as crianças em que o conceito é ao mesmo tempo um instrumento de análise de uma cena e um instrumento para a sua criação. Dominar o conceito implica tanto em poder analisar melhor as cenas quanto em criálas de modo mais consciente e de acordo com os objetivos estabelecidos. E para isso, o conceito não pode ser apenas “apresentado” ou mesmo mencionado diversas vezes para os estudantes. Os conceitos devem ser objetos de suas ações, referenciando tanto os processos de análises e sínteses teóricas, quanto os processos de construção das cenas propriamente ditas.

\section{Episódio 3: Estrutura da organização do ensino}

Unidade conceitual de análise: Atividade orientadora de ensino

\section{CENA 1: Criando momentos de análise das cenas produzidas.}

\section{narração da cena:}

A análise das cenas constituiu-se em um dos momentos de trabalho mais importantes para o processo de apropriação dos conceitos. Os educadores procuravam garantir que as análises fossem feitas tendo por referência os elementos de criação, o que fazia com que, nesse trabalho, educadores e educandos analisassem as cenas produzidas a partir do modo geral de ação indicado por cada conceito, bem como pela composição de todos esses conceitos na produção de um objeto artístico circense.

\section{cenário um:}

Os estudantes, após construírem caixas com cartolinas, começam a criar cenas de acordo com algumas indicações dos educadores e/ou livremente, apenas atendendo a uma das intencionalidades: ser engraçada, ser bonita etc (aula 3). Cada criança ou grupo de crianças que criava uma cena era solicitada pelos educadores para apresentála aos colegas. Um grupo de estudantes cria uma cena em que a caixa está muito pesada e acaba os derrubando, um por um.

Narrador: após a apresentação, a educadora pede para quem estava assistindo dizer o que pensou da cena e conduz as discussões instigando os estudantes a pensarem as razões que faziam a cena ser engraçada ou como ela poderia ser. 
Vinícius achou que a cena foi engraçada pelas expressões dos meninos (fazendo força) e caindo no chão com o peso da caixa. Outras crianças não acharam a cena engraçada. A educadora pergunta se eles teriam uma idéia de como transformá-la em uma cena engraçada.

\section{cenário dois:}

Após a apresentação de cada um dos grupos de personagens, os professores organizam uma roda de discussão para avaliações das cenas vistas (aula 7). Essa dinâmica repetiuse nas aulas seguintes (8 e 9 ).

Prof II: "Vocês lembram da cena de algum colega e da avaliação que vocês fizeram?"

Thales: "eu lembro da cena do Marcelo e do Rui e lembro da cena do Luis, fazendo malabarismo (faz gesto do malabarismo)"

Prof II: “E o que que você achou dessas cenas, você fez alguma avaliação delas?”

Thales: as duas foram ótimas"

Prof II: "Tinham duas cenas com diabolô, não era? A do Marcelo e a do Rui era o quê?”

Luis: "Era comédia..."

Prof II: "Era uma cena engraçada?”

Narrador: Crianças concordam.

Prof II: "E o do Leo e do Rui? Era engraçada também?"

cenário três:

Educadores e educandos, em roda, analisam aspectos da cena das contorcionistas (aula 7):

Prof II: “O contorcionista era uma cena engraçada também? O que que o contorcionista tentou passar pra gente se não era de ser engraçado?” Luan: "Coisa elástica..."

Prof II: "Mas o que que elas queriam de intenção pro público? Que o público

ficasse admirado, que achasse bonito, que achasse engraçado...?”

Luan: "Que achasse bonito."

Prof II: "Que achasse bonito? Acha, Luan?"

Luan: “Colocar o pé na cabeça é muito difícil!”

\section{cenário quatro}

Educadores e educandos, em roda, analisam o tempo de duração das cenas apresentadas na aula anterior (aula 7):

Prof I: "E o tempo da nossa apresentação do circo, hein? Nós tivemos cenas que vocês acharam que foram rápidas de mais ou..."

Luis: "Demorada!"

Prof II: "Que cena que foi demorada Luis?”

Luis: "A do Marcelo e do Rui”"

Prof II: "Vocês acharam também, que foi demorada?”

Narrador: Algumas crianças concordam.

Prof II: "Mas o que que acontece quando uma cena é muito demorada?”

Rui: "Todo mundo fica esperando assim... ai... fica com a cara" [faz cara de sono].

Prof II: "Sabe o que a gente pensou, também, dessa cena do Rui e do diabolô? O 
Thales falou pra gente que achou que foi bem legal, né? Que foi uma cena engraçada... também achei. Agora, também concordo com o Luis, acho que foi uma cena demorada e o que aconteceu foi que vocês ficaram repetindo muitas vezes o mesmo movimento, não foi?”

Rui: "EU?!"

Prof II: "Você e ... quem era, o Marcelo, né!?”

Luis: "É toda a hora vocês ficavam trocando baqueta, jogando um pro outro." Prof II: "Vocês fizeram a mesma coisa várias vezes... daí por isso que a cena ficou demorada. Então pode fazer um pouquinho menos, porque todo mundo já viu o que vocês iam fazer, já deu risada. Daí se a gente começa a repetir várias vezes a mesma coisa..."

Luis: "Fica sem graça"

Prof II: (concordando com a cabeça) “começa a ficar sem graça. Então só diminui um pouquinho a quantidade dos movimentos”.

\section{CENA 2: Organizando o processo de planejamento das cenas.}

\section{narração da cena:}

O processo de criação das cenas deveria ser precedido, necessariamente, por um processo de reflexão e planejamento das mesmas. A proposta era fazer os estudantes pensar em cada um dos elementos de criação das cenas de modo que os mesmos pudessem servir de orientação para as tarefas de criação.

\section{cenário um:}

Organizamos uma apresentação dos principais elementos de criação das cenas para os educandos e apresentamos os seus conceitos (aula 4, ver anexo V). Para cada elemento, os educadores procuravam trazer exemplos de cenas assistidas no vídeo e/ou já realizadas por eles ao longo das aulas anteriores.

Prof I:

- (intencionalidade) "O primeiro dos elementos de nossa cena é a intenção, vocês lembram quando a gente conversou sobre isso? Que tipo de cena a gente vai querer fazer? (...) quais eram as intenções, vocês lembram? (...) a gente tem uma cena engraçada (...) de suspense... que personagem pode fazer o público ficar com medo? Um exemplo é a pirâmide, aí começa a subir tanta gente e eles começam a balançar de um jeito que a gente acha que vai cair todo mundo... então é uma cena de suspense, porque a gente fica tão atento, com medo que eles caiam e aconteça alguma coisa errada que a gente fica apreensivo, prestando atenção.(...) Além da intenção da cena, da gente pensar o que que a gente quer que o público sinta, a gente vai ter que pensar nos movimentos (...)”

- (coreografia) “...depois de pensar o movimento, a gente vai ter que pensar a ordem dos movimentos, numa cena, normalmente tem mais de um movimento... então eles ensaiaram uma seqüência... essa é a coreografia da cena que a gente vai ter que pensar (...)"

- (ângulo de visão) “... esse elemento da cena, a gente ainda não conversou ainda bem. Vocês já foram num circo em que ele é todo redondo? E vocês já viram um circo que o palco é só de frente? Aquele que a gente assistiu era redondo mas a platéia ficava só de um lado (...) quando o chão do circo é redondo os personagens tem que apresentar para vários lados, pra toda a platéia poder assistir (...), as vezes eles dão a volta, começam 
apresentando de um lado, vira e apresenta pro outro... quando o palco é retangular, só tem uma frente, o público está só de um lado.”

- (acessórios) "Outra coisa que a gente vai pensar na nossa cena e que a gente já começou a fazer isso... quais objetos a gente vai usar na nossa cena (...) a gente tem que pensar na maquiagem, nas roupas... além das roupas, dos acessórios, dependo da nossa intenção da cena (...) que tipo de música a gente pode usar.”

- (narração) “(...) alguns circos não usam o narrador que a gente conhece, esse que apresenta, as vezes os próprios personagens, eles apresentam a cena. Eles podem apresentar contando, eles podem apresentar enquanto eles fazem a cena. Então a gente vai pensar se no nosso circo vai ter um narrador antes e que conte a cena ou se o próprio personagem vai apresentar para o público...”

\section{cenário dois:}

Como uma forma de colaborar no processo de criação das cenas, criamos uma ficha orientadora que trazia os principais elementos de criação e estavam dispostas seqüencialmente e com espaços para serem preenchidos (anexo I). Além de explicarmos o uso das fichas para os planejamentos (aula 4), colocamos nas paredes da sala cartazes que traziam esses mesmos elementos e os conceitos a que se referiam.

Prof II: "Cada grupo vai receber uma fichinha... e vai ter que pensar em tudo aquilo que a Bruna [educadora] estava falando com a gente... nessa fichinha só tem uma coisa diferente que a gente não viu hoje... o desenvolvimento da cena, o que que é isso? É como se fosse o enredo ou a história da cena... eu posso combinar com o meu grupo se eu vou criar uma historinha que a gente vai contar para o público ou não. Mas de qualquer forma eu tenho que pensar como é que a cena vai começar, como é que vai ser o meio da cena e como é que a cena vai terminar...”

\section{cenário três:}

Após elaborarem os planejamentos de suas cenas, os educandos deveriam socializar os planos elaborados (aula 5) de modo a realizarmos uma primeira análise coletiva das cenas. Entretanto, e ainda que os professores orientassem as crianças a contarem as cenas que criaram, os grupos liam seus planejamentos o que dificultou a realização de uma análise coletiva dos planos.

Prof I: "Não precisa ler tudo, fala quais as mágicas"

Narrador: os mágicos listam as mágicas (a partir dos objetos que serão utilizados: a da corda, a do lenço, a das cartas e a da água)

Prof I: "Não precisa ler [para os equilibristas] só conta para gente. Como vocês vão começar a cena?”

Narrador: Rui começa a leitura.

Prof I: "Não precisa ler, fala o que vocês organizaram"

Este episódio apresenta dois momentos de trabalho que julgávamos nucleares no processo de ensino e que contribuíram para a concretização do trabalho de apropriação dos conceitos em nosso experimento didático: os momentos de análises das cenas produzidas (cena 1) e os momentos de organização do planejamento das cenas (cena 2). 
Diferentemente dos episódios anteriormente analisados (episódios 1 e 2), em que consideramos de forma mais específica as ações docentes, no presente episódio focamos a análise da estrutura geral do ensino, ou mais bem, das tarefas de aprendizagem que foram propostas. A análise das tarefas de aprendizagem nos permite tecer considerações mais amplas sobre a estrutura de ensino, sobre os modos de efetivação das intenções pedagógicas enunciadas no planejamento, considerando as condições reais de ensino que tivemos.

As tarefas de análise das cenas criadas e as discussões coletivas sobre elas, constituíram-se como uma forma de avaliação tanto dos modos de composição dos elementos de criação dentro de uma cena (o modo de ação geral a ser apropriado com o ensino da atividade circense), quanto dos conceitos presentes em cada um dos elementos. As ações de análise das cenas nos pareciam ser um momento particularmente importante no processo de apropriação dos conceitos, posto que permitiam aos educadores trabalhar com os conceitos como instrumentos de análise dos educandos (e, assim, como o objeto direto de suas ações), bem como explicitar os modos gerais de ação existentes em cada um dos conceitos.

Desta forma, analisar uma cena configura-se como uma forma de analisar os próprios conceitos. Por vezes, os conceitos são diretamente discutidos nos momentos das análises, buscando identificá-los em cada uma das cenas (cena 1, cenários 2 e 3). Outras vezes, as análises problematizavam mais diretamente os modos de ação presentes e/ou possíveis em cada cena e de acordo com o elemento conceitual que estava sendo discutido, caso da sugestão da educadora para os educandos recriarem uma cena, tentando deixá-la engraçada (cenários 1 / cena 1) e da indicação da necessidade de escolher uma seqüência de movimentos para cena, executando-a apenas uma vez (cenário 4/ cena 1). Nestes casos, as ações de análise tinham um duplo papel: a) estudar o conceito e o modo geral de ação do conceito; b) aperfeiçoar a cena elaborada a partir dos conceitos estudados.

Em nosso planejamento, as tarefas de análise das cenas estavam previstas e ocupavam um espaço e um tempo de trabalho maior do que de fato puderam ocupar em nosso experimento didático. Havíamos planejado um trabalho com o estudo de cada um dos elementos de criação em que eles (em momentos separados) ocupariam o papel de objeto de ação dos educandos. Essa tarefa foi sintetizada no planejamento, como a segunda tarefa geral de aprendizagem: "Resolução de tarefas de aprendizagem com base no modo geral de ação disponibilizado pelo educador: criação de cenas modelos para o estudo dos elementos de criação”.

A proposta era que, num primeiro momento, os educandos criassem cenas buscando organizar um dos elementos de criação das cenas: o ângulo de visão, a coreografia, a 
intencionalidade, o movimento, a narração etc e que, com base nelas, pudéssemos discutir e sistematizar os conceitos e modos de ação presentes em cada elemento. Num segundo momento, os estudantes criariam cenas modelos com os personagens circenses, focando em um dos elementos de criação. Esses dois trabalhos representariam o momento de estudo das abstrações teóricas e serviriam de subsídio para os processos subseqüentes de criação das cenas circenses (composição dos elementos), além de constituir um permanente exercício de análise das cenas e de seus conceitos.

Em virtude de nossas condições reais de ensino, cuja limitação central foi a disponibilidade de tempo, tivemos que encurtar esse trabalho de estudo das abstrações. Para chegarmos ao processo final de ensino (elaboração de cenas circenses), tivemos que encurtar o processo inicial de estudo dos conceitos.

Ainda que o estudo conceitual não tenha sido tão profundo quanto o planejado, ele se manteve como um elemento presente, quer nas ações docentes, quer nas ações discentes. Nesse contexto, podemos situar a importância dos momentos de análise das cenas (que deram início na aula 3, antes mesmo de explicitarmos todos os elementos conceituais para os educandos), como um espaço e um momento de trazer os conceitos como objeto de análise e ações dos educandos, isto é, de colocar os estudantes em movimento no processo de apropriação dos conceitos.

O segundo momento deste episódio abarca as tarefas de aprendizagem relacionadas à organização do planejamento das cenas (cena 2). Para a elaboração de suas cenas os estudantes deveriam não apenas “ter uma idéia” sobre ela, mas conseguir desenvolvê-la em todos os aspectos possíveis, isto é, controlar e compor em suas cenas cada um dos elementos de criação estudados.

Para isso, avaliamos ser importante a materialização desse planejamento, feita com a ajuda da "ficha orientadora”,42, (cenário 2, cena 2). A ficha orientadora desempenhou papéis distintos nos diferentes grupos. Para um grupo, serviu, de fato, como uma ferramenta de criação, como um instrumento organizador do processo de elaboração e síntese da cena (ver ficha dos equilibristas, anexo II). Para outro grupo, ainda que tenha contribuído de alguma forma para a organização do processo de criação dos estudantes (por apontar os elementos que deveriam organizar), ela não conseguiu ajudá-los a compor uma síntese de seus processos de criação (ver ficha dos acrobatas, anexo III).

\footnotetext{
${ }^{42}$ Ver anexo I.
} 
Os planejamentos deveriam servir de referência tanto para as ações de criação e ensaios das cenas por parte dos estudantes, quanto para as intervenções dos educadores nos processos de criação dos grupos. Ainda que o planejamento da cena aponte apenas para uma idéia inicial desta, e que essa idéia pudesse mudar ao longo dos ensaios (como muitas vezes ocorreu), era importante que os educandos tivessem essa ferramenta de criação. Importante porque os "obrigava” a pensar em todos os elementos de criação durante a elaboração das cenas. Neste início de trabalho com os conceitos de criação das cenas não podíamos esperar que os estudantes utilizassem prontamente e voluntariamente, todos esses elementos. E nem se quer esperar que eles fossem, espontaneamente, conscientes dos conceitos. Assim, para todos os grupos a ficha contribuiu para o processo de "trazer para a consciência” os elementos de criação das cenas, na particularidade da cena que estava sendo elaborada por eles.

A partir dessa perspectiva, julgamos importante criar um momento de socialização dos planos elaborados (cena 2, cenário 3). Ainda que os planos não estivessem terminados e fossem, em alguns aspectos, provisórios, queríamos, a partir dos planejamentos, constituir um primeiro momento coletivo de avaliação das cenas. A proposta e a orientação dos educadores era para que cada grupo contasse a sua cena para os demais e, assim, fossemos avaliando o modo como o grupo compôs a cena tendo por base os elementos de criação. Contudo, e talvez pelo fato do plano ainda não constituir para os educandos uma síntese da cena elaborada, mas muito mais um recurso para o seu processo de criação, os estudantes, de maneira geral, tiveram dificuldades para "narrar” suas cenas, para contar a cena em sua totalidade, optando pela leitura dos diferentes elementos de criação que haviam planejado.

Podemos dizer, então, que a ficha orientadora, para a maioria dos estudantes, não serviu como uma forma de criar uma imagem total da cena, isto é, de sintetizar a cena em seus múltiplos aspectos. Essa função, na verdade, nem poderia ser esperada. Em primeiro lugar, porque os educandos estavam, ainda, nos primeiros passos de seus processos de apropriação dos conceitos/elementos de criação das cenas. Em segundo lugar, ter a idéia geral da cena em seus múltiplos aspectos, poder compor uma cena dominando todos os elementos de criação, constitui-se, justamente, no produto final do ensino proposto por nós: a apropriação de um modo geral de ação no processo de criação de uma cena, ou em outros termos, a formação do pensamento estético-artístico. E um produto que, mesmo ao final de nosso experimento didático, só poderíamos ver os esboços, posto que o fim das nossas intervenções não coincidiu com o fim dos percursos de aprendizagem dos estudantes no desenvolvimento do pensamento estético-artístico. 
Deixamos propositalmente para o final as discussões relativas a uma última cena presente neste episódio: a apresentação dos elementos de criação, conceitos e modos de ação, (cena 2, cenário 1). Embora esta cena constitua, cronologicamente, o início do trabalho conceitual com todos os elementos de criação, a primeira apresentação e sistematização dos conceitos que seriam estudados pelos educandos, trata-se de uma cena que nos permite analisar de muitas formas a questão do trabalho com os conceitos teóricos como finalidade do ensino e os modos de organização do ensino para esse fim.

Pudemos observar que do início ao fim do trabalho pedagógico, isto é, do planejamento à última aula, os educadores procuraram organizar o trabalho dos educandos de modo que os conceitos ocupassem o papel de instrumentos para suas ações, tanto de criação quanto de análise, das cenas circenses. Em nosso experimento didático, os conceitos teóricos (as abstrações relativas ao processo de criação de cenas circenses) e a organização do ensino com base em problemas de aprendizagem (mais do que problemas prático-concretos), foram referências para o planejamento e para as ações docentes. Isso, por si, orienta o ensino para uma determinada direção; configura o ensino de uma determinada forma.

Entretanto, precisamos reconhecer que ter esses elementos como referência para o ensino, não implica, direta e necessariamente, que o trabalho pedagógico tenha se concretizado desta maneira. Em outras palavras: ter a finalidade de desenvolver o pensamento teórico nos educandos e planejar o ensino tendo por base essa finalidade não é garantia absoluta de concretização do ensino de acordo com esses fins.

Embora possamos parecer negativistas ao tecermos essas considerações, queremos apenas pontuar com elas a não linearidade entre as intenções pedagógicas mais gerais e a organização do ensino propriamente dito. Dizer que não há linearidade, não significa dizer que há ruptura; significa dizer que entre um elemento e outro, entre as intenções pedagógicas e as práticas de ensino, precisamos de um elemento mediador: uma "teoria didática” ou um “modo geral de organização do ensino”.

Assim, para avançarmos no processo de construção de um modo geral de organização do ensino referenciado na teoria histórico-cultural (processo esse que não se inicia ou termina aqui) podemos, com base nos nossos dados, fazer as seguintes perguntas: qual a forma que o nosso ensino, orientado pela perspectiva de apropriação de conceitos teóricos no campo das atividades artísticas, se configurou? Em quais aspectos nos aproximamos e em quais nos afastamos de um ensino que efetivamente contribua para a formação do pensamento teórico nos educandos? E mais importante: quais generalizações a respeito do ensino que se propõe a desenvolver o pensamento teórico nos educandos podemos extrair de nossas análises? 
Não esgotaremos as respostas a essas perguntas neste momento, mas esboçaremos alguns caminhos para, nas sínteses de nosso trabalho, a elas voltarmos.

Como já mencionamos anteriormente, o tempo de ensino que tivemos disponível para o nosso experimento didático, embora não fosse pouco ${ }^{43}$, nos obrigou a fazer determinados ajustes no planejamento original.

O estudo das abstrações (elementos de criação das cenas), deveria ocupar uma parte especial do ensino, em que os educandos teriam como objeto de suas ações essas abstrações ou conceitos e que pudessem iniciar, de modo mais sistemático, a apropriação dos modos gerais de ação presentes em cada um dos elementos. Para isso, havíamos planejado uma tarefa de aprendizagem em que os educandos criariam cenas modelo, destinadas à análise e “utilização” dos elementos de criação das cenas.

As cenas seriam criadas de acordo com um objetivo previamente definido pelos educadores (criar uma cena engraçada; criar uma cena organizando a visão do público...) e a partir de uma orientação inicial do educador a respeito do elemento com o qual as crianças iriam agir. Realizada a cena, educadores e educandos passariam a avaliá-la e caberia ao educador realizar uma primeira síntese conceitual do elemento estudado, explicitando o modo de ação presente nele. Com esta organização, garantiríamos um momento de trabalho especificamente voltado para o estudo dos conceitos, em que os educandos agiriam tanto com as sínteses conceituais fornecidas pelos educadores, quanto com o processo de criação de cenas a partir daqueles conceitos.

De modo bastante sintético, esboçamos essa organização em nosso ensino, mas apenas para um elemento (a intencionalidade da cena), o que nos serviu como um "modelo" de como pode se realizar um ensino a partir daquela intenção.

Desde o início do trabalho pedagógico, sabíamos da impossibilidade de realizar um estudo dos conceitos de modo tão específico e prolongado como queríamos. Tínhamos, assim, que solidificar os demais mecanismos de ensino destinados à apropriação dos conceitos pelos educandos. Dois deles, como já analisamos, foram os trabalhos com as análises das cenas e com os seus processos de planejamento ou criação.

Contudo, tínhamos uma "lacuna" que precisava ser preenchido que se referia a explicitação, para os estudantes, das abstrações, dos conceitos de cada um dos elementos de criação. Precisávamos sistematizar para os educandos todos os elementos de criação, seus

\footnotetext{
${ }^{43}$ Tivemos 11 encontros com os estudantes, uma vez por semana, durante um período total de um semestre. Os nove primeiros encontros tiveram duração de $2 \mathrm{~h}$. O décimo encontro foi um último ensaio geral (com $1 \mathrm{~h}$ de duração) e o décimo primeiro encontro foi o dia da apresentação do espetáculo elaborado ao longo das aulas.
} 
conceitos, posto que essa sistematização se configuraria como ponto de partida para o processo de sua apropriação. Permitiria que educadores e educandos falassem a mesma linguagem e que utilizassem os elementos (os conceitos) como instrumentos de seus trabalhos. Foi pensando nessas questões que organizamos uma aula em que apresentamos para os estudantes todos os elementos de criação das cenas (cena 2, cenário 1).

Este trabalho desenvolvido com os educandos era uma forma de introduzi-los aos conceitos (objeto de estudo) e apresenta tanto uma positividade - ao definir os conceitos, estabelecendo uma linguagem comum e fornecendo sínteses para os alunos refletirem e construírem suas próprias sínteses conceituais - quanto uma negatividade - ao não conseguir trabalhar, de fato e plenamente, com os conceitos.

Não esperávamos e não poderíamos esperar, esgotar o trabalho com os conceitos naquele momento. Tratava-se de uma etapa inicial do percurso de estudo dos conceitos; a eles voltaríamos em outros momentos do ensino, em especial naqueles de análise e criação das cenas. Mas justamente por ser o momento inicial e, mais do que isso, o momento que tínhamos para trabalhar diretamente com os conceitos, precisava ser um trabalho que fornecesse de modo bastante correto as sínteses conceituais para os estudantes.

Em nosso experimento didático, esse momento inicial de trabalho com os conceitos acabou sendo deficitário em termos de precisão conceitual. A apresentação dos conceitos, conforme descrito no cenário 1 (cena 2) foi superficial. Os conceitos foram sistematizados pelos educadores mais em suas nomenclaturas e definições formais (através de exemplos empíricos que nos permitiam identificar o conceito em uma cena ou outra), do que em seus aspectos propriamente teóricos, isto é, na explicitação do modo geral de ação presente em cada conceito.

Poderíamos indicar duas razões iniciais para esse fato. Por um lado, os educadores poderiam ter um domínio relativamente fraco dos conceitos, o que, sem dúvida, dificultaria o seu ensino. Por outro lado, e o que julgamos mais provável, poderia haver uma quantidade excessiva de variáveis (conceitos inclusive) para serem trabalhados de uma só vez, em um tempo curto (trinta minutos, aproximadamente) e sem a realização de ações práticas com os conceitos pelos educandos.

Já afirmamos que o trabalho com as definições conceituais representa um dos elementos e uma das ações no processo de apropriação dos conceitos. E já afirmamos, também, que as sínteses fornecidas pelos educadores não se configuram, em si mesmas, nem como o ponto de chegada do processo de apropriação dos conceitos pelos educandos, nem como uma forma de minimizar as ações dos estudantes. Os conceitos sistematizados pelos 
educadores constituem-se, ou devem se constituir, como um meio, um instrumento para a resolução das tarefas de aprendizagem propostas para os estudantes. As sínteses conceituais fornecidas pelos educadores devem se configurar, no processo educativo, como materiais de estudo para as ações dos educandos.

Deste modo, a debilidade que apontamos no nosso trabalho de sistematização dos elementos conceituais, não pode se dar pelo fato do educador ter fornecido sínteses "prontas" aos educandos, posto que como já vimos tais sínteses não são, em si, negativas, embora possam o ser, a depender da forma como forem realizadas. É preciso saber quando o ensino, quando as ações dos docentes, trabalhando com as sínteses conceituais, constituem-se em uma ferramenta para o processo de aprendizagem dos educandos e quando se configuram como uma espécie de "verbalismo” do ensino. A síntese conceitual e as ações dos educandos com essas sínteses devem ser cuidadosamente planejadas pelos educadores para que o conceito não seja apenas uma abstração, mas torne-se uma referência para as ações dos educandos.

Algumas considerações podem ser feitas com relação a essa questão. Quando a fala do professor não indica explicitamente ações para os educandos, nem ações reflexivas, nem ações materiais, quando as sínteses conceituais não são capazes de contribuir para os processos de análise e síntese dos alunos sobre o objeto de estudo, quando os conceitos são apresentados em seus aspectos formais, acaba-se por ratificar a associação entre "transmissão de conceitos/postura passiva dos estudantes”. Nesta situação, a fala dos educadores acaba virando, efetivamente, um "falatório"; o ensino, uma verbalização e os educandos, meros ouvintes do processo.

Desta forma, temos um ensino pouco eficiente do ponto de vista da formação conceitual não quando os conceitos são fornecidos como material/instrumento para o trabalho dos educandos, mas quando o que são fornecidos para os educandos sejam "pseudoconceitos”; a superficialidade do conceito. Ou seja, a debilidade no ensino não está quando os professores sistematizam maximamente os conceitos (em seus múltiplos aspectos), mas quando o sistematizam apenas em suas relações superficiais.

Na síntese de nosso trabalho, voltaremos a algumas dessas discussões no sentido de esboçarmos um modo geral de ação docente. 
Episódio 4: Intervenção dos educadores no processo de criação das cenas.

Unidade conceitual de análise: Atividade orientadora de ensino

\section{CENA 1: As ações dos docentes nos processos de criação das cenas}

\section{narração da cena:}

Os ensaios das cenas eram sempre acompanhados de perto pelos educadores que se revezavam nos grupos garantindo, quase sempre, a presença de um educador em cada grupo. Deste modo, os grupos tinham um auxilio em seus processos de criação, não apenas com a indicação de "novas idéias", mas, sobretudo, com a orientação dos modos de ação para a composição dos elementos de criação em uma cena.

\section{cenário um:}

Durante os primeiros momentos de planejamento da cena dos acrobatas (aula 4), uma educadora auxilia todo o processo de criação dos estudantes. A professor procura ajudá-los a pensar estruturalmente a cena, posto que eles estavam tendo dificuldades nesse aspecto (tinham dificuldade para planejar apenas verbalmente as cenas, para ouvir as idéias dos outros e debatê-las).

Prof I: “Alem da pirâmide, a pirâmide vai ser a primeira cena que a gente vai fazer?” Narrador: Crianças concordam que sim. Daniel lembra-se da cena com a centopéia Prof I "Vamos tentar pensar e aí depois a gente faz a ordem?"

Narrador: Eles concordam, mas logo estão realizando os movimentos de novo. As duas educadoras que estavam com o grupo propõem organizar uma roda com as crianças acrobatas.

Prof III: [para o Vinícius, que ia sair de novo para ensaiar] "Vamos pensar primeiro...”

Prof I: "Gente, o que que está acontecendo: o Daniel teve uma idéia, nem todo mundo ouviu qual foi a idéia dele, vocês já estão tentando ensaiar e a gente não pensou a seqüência.”

Narrador: Os estudantes vão conseguindo caminhar no planejamento, sempre com o auxilio de pelo menos um educador. Sem ele, as crianças se dispersam e "treinam os movimentos" ao invés de realizar a cena.

\section{cenário dois:}

Uma educadora auxilia o processo de criação e ensaio da cena dos equilibristas com bastão (aula 8). O grupo já havia criado a idéia da cena e estava ensaiando. A professora problematiza alguns elementos de criação das cenas para que eles pensem e demonstrem como estão presentes na cena.

Prof II: "Vocês lembram da cena de vocês com o bastão quando vocês apresentaram?” Estudantes: "Sim"

Prof II: “Como é que foi?”

Narrador: Os educandos começam a falar juntos.

Vinícius: “... aí o Marcelo ficava assim (faz movimento) meio atrapalhado”

Prof II: "O Marcelo vai ser a parte engraçada?”

Narrador: Marcelo concorda com a cabeça.

Prof II: "Não ficou muito claro isso. Vai entrar um de cada vez, é isso? O Luis entra primeiro e vai ficar equilibrando? Pra ficar bonito, é isso? Aí depois entra o 


\section{Vinícius também pra ficar bonito?”}

Luis: "Mais ou menos..."

Narrador: Luis e Vinícius contam que eles também vão ter uma parte engraçada no final, em que deixam cair o bastão.

Prof II: "Mas se só cair o bastão... [Vinícius continua mostrando a cena] "É pro público achar graça (cena em que um deles deixa cair o bastão)?”

Marcelo: "Graça e desgraça...”

Prof II: “Como é que a gente vai saber que ele [Luis] é o professor de vocês?”

Narrador: Vinícius fala de terem roupas diferentes

Prof II: "Mas ele vai ter uma cena com vocês que vai tentar ensinar pra vocês?”

Narrador: Professora, então, sugere que ensaiem do começo ao fim a cena. Ela os acompanha no ensaio. Antes de começarem ela os indaga sobre o final da cena:

Prof II: “Como é que vai ser o final da cena?”

Vinícius: “Assim ó: todo mundo cai...” [e cai no chão, deixando o bastão fazer ruído]

Narrador: Vinícius vai até Luis e Marcelo, para combinarem o final da cena.

Professora sugere um novo ensaio do inicio ao fim para os equilibristas. No final

da cena, professora chama novamente os meninos para conversarem sobre sua cena.

Ela faz uma sugestão: do Luis e do Vinícius olharem com cara de deboche para o Marcelo quando ele estiver se apresentando, para caracterizar mais para o público que ele está fazendo tudo errado.

Prof II: "Pensei uma coisa: em vez de vocês ficarem cantando a música desse jeito enquanto o Marcelo está apresentando, porque que vocês não ficam olhando assim (faz cara de reprovação)?”.

Narrador: as crianças aprovam a sugestão e na apresentação que fazem naquele dia, para os colegas e demais educadores, incorporam a sugestão dada pela educadora.

\section{cenário três:}

Uma educadora auxilia no processo de criação dos narradores (aula 8). Os narradores em dupla foi uma idéia relativamente tardia no planejamento do espetáculo. A professora inicia e acompanha todo o planejamento e os primeiros ensaios da dupla. Ela vai sugerindo formas de fazer a cena e conteúdos da fala, além de pontuar alguns elementos de criação para eles.

Prof I: "Então, mas eu acho legal isso, vocês estão juntos daí cada um... sabe aquela brincadeira...”

Narrador: não é possível ouvir, mas as crianças fazem que conhecem a brincadeira e depois a esboçam na fala que tinham elaborado. Seria uma espécie de jogral:

Thales: "Irrespeitável...” (faz gesto para Luan continuar a frase).

Luan: “...público...”

Narrador: Os estudantes seguem pensando nos jeitos de fazerem as falas.

Thales: "Aí a gente fala ao mesmo tempo!"

Narrador: A educadora sugere que eles olhem para o público, abram bem o braço e anunciem o personagem. Thales a imita. Eles fariam isto depois de brincar com o público, anunciando o personagem um no ouvido do outro. Para explicar como seria essa parte da cena, a professora a faz com o Luan: professora cochicha a próxima atração no ouvido do Luan indicando que o Thales faria isso com ele"

Prof: “ 'Você ouviram' [para o público]? Vocês podem brincar assim. 'Vocês não ouviram?' Daí vocês falam junto: 'Mágica [abrindo os braços] !!’”.

Narrador: A educadora pede para eles retomarem o ensaio desde o começo.

Prof I: "Vai, vamos lá!” Ela fica de frente para os meninos, orientando as ações deles 


\begin{abstract}
"Primeira palavra..." (aponta para Thales).
Thales: "Irrespeitável..."

Luan: “... público...”

Narrador: Eles continuam a cena. Em um determinado momento o estudante Luan fica sem saber o que falar porque Thales mudou a fala que tinham ensaiado. A educadora orienta:

Prof I: "Dependendo de como ele começar, você tem que continuar"

Luan: “...Nós vamos...”

Thales: “...apresentar...”

Luan: “...os...”

Prof I: "Olha pra cá...”

Narrador: Ela procura orientá-los para a posição da platéia. Terminado o ensaio do primeiro personagem, A educadora sugere que pensem e ensaiem o próximo personagem que vão anunciar:

Prof I: “Agora outro [personagem]: os palhaços. Vocês vão intercalar, assim alternado? (...) Vocês podem gritar assim pro público 'quero ver se vocês descobrem a próxima atração: eles não usam nariz vermelho; não usam sapatos grandes; mas eles são uns....!'”.

Narrador: A educadora segue o ensaio com os narradores, auxiliando nas falas, expressões, jeitos de lidar com o público...Ela mais uma vez, pede para os meninos ensaiarem de novo, desde a cena dos mágicos até a dos palhaços. Após a cena ensaiada, a professora sugere o planejamento e ensaio de outro personagem.

Prof I: “Agora vamos pensar na dos contorcionistas? A deles é uma cena bonita, como é que a gente pode começar a cena com eles...?”

Narrador: Quando os meninos narradores vão apresentar a cena sozinhos (aula 8), sem o apoio da professora, que estava na platéia assistindo junto com os demais educadores e as demais crianças, eles demonstram ter incorporado muitos elementos ensaiados com a professora. Fazem todas as cenas com começo, meio e fim, aproveitando algumas piadas, falas e posturas sugeridas pela educadora e acrescentando outras. $\mathrm{O}$ principal é que tinham incorporado os procedimentos para a criação da cena.
\end{abstract}

O processo de criação de uma cena inicia-se no planejamento propriamente dito, passa pelos ensaios e termina nas avaliações após a apresentação das cenas, que dão novos elementos para repensar a cena e reelaborá-la. Em todo esse processo, a presença do educador se fez fundamental, orientando os estudantes tanto nas tarefas práticas (criar a cena), quanto e principalmente, nas tarefas de estudo, para que em seus processos de criação os estudantes reconhecessem e utilizassem os conceitos como instrumentos de suas ações.

No presente episódio, selecionamos três situações de ensino em que podemos analisar algumas ações docentes voltadas, de modo mais direto, para o processo de criação das cenas, isto é, para o modo geral de ação presente nas atividades artísticas: a composição dos diversos elementos de criação formando um objeto artístico.

De modo geral, as ações docentes presentes neste episódio procuram tornar o processo de criação (e não apenas um ou outro conceito) mais consciente para os educandos; buscam 
fazê-los ter mais domínio do planejamento que elaboraram e mais consciência dos objetivos que estabeleceram para a cena. As intervenções dos educadores não são trabalhadas apenas como “idéias novas” para a cena, mas, sobretudo, como uma orientação do próprio processo de criação, do modo geral de ação para a criação de um objeto artístico circense. Para as crianças, as ações propostas pelos educadores servem como uma forma de contribuir para seus ensaios.

Uma vez que as ações dos educadores enfatizam o modo de ação dos educandos durante os ensaios de suas cenas, enfatizam a idéia de "composição dos elementos de criação" - ou o domínio do próprio processo de criação de uma cena - podemos identificar algumas intervenções recorrentes: pedir para as crianças contarem o que planejaram, o que as faz explicitar o desenvolvimento da cena, como começa, como é o meio, como termina (cenário 2); fazê-las explicitar a intenção da cena, o objetivo geral da cena (cenários 2 e 3); pedir que façam a cena do começo ao fim (cenários, 2 e 3); pedir para que planejem a cena antes de ensaiá-la, enfatizando que realizar o movimento não é o mesmo que realizar a cena (cenário 1).

Via de regra, essas intervenções demonstram ser bastante organizadoras para os educandos, permitindo que eles, em outros momentos, caminhem sozinhos em seus processos de criação. O educador age, efetivamente, como um colaborador no processo de desenvolvimento dos educandos; age em suas zonas de desenvolvimento próximo, posto que visa contribuir para o processo de desenvolvimento de uma nova conduta nos estudantes: o pensamento estético-artístico, quer realizando perguntas orientadoras, quer resolvendo a tarefa junto com as crianças.

As perguntas orientadoras buscam, geralmente, explicitar ainda mais o problema para os educandos; colocam ou reformulam as questões para que eles possam ter mais consciência das mesmas e tentem buscar as respostas. Um exemplo está na seguinte fala de uma educadora para o grupo dos equilibristas:

"Como é que a gente vai saber que ele [Luis] é o professor de vocês? (cenário 2/cena 1).

A educadora coloca uma questão que provavelmente não estava clara para as crianças: como demonstrar para o público que aquele personagem ia ter um papel diferente na cena? Como posso caracterizá-lo para o público? Até então, os educandos tinham uma idéia geral (ter um professor que vai ensinar um personagem que não sabe equilibrar os bastões), mas não haviam pensado como explicitar isso, tanto que no primeiro ensaio da cena, não era possível, para o público, perceber a existência de um "professor”. A pergunta da educadora, 
não explica e nem indica a solução do problema, mas o reorganiza para que ele seja objeto de atenção dos estudantes.

Neste mesmo tipo de intervenção está a fala de uma educadora durante suas intervenções nas cenas dos narradores:

\section{"Agora vamos pensar na dos contorcionistas? A deles é uma cena bonita, como é que a gente pode começar a cena com eles...?” (cenário 3/cena 1).}

Nesta fala, a educadora não apenas procura explicitar melhor o problema para os estudantes, mas também indica um princípio para a sua solução: partir da intenção do personagem que eles vão narrar. Esta informação, se não responde ao problema de criar uma cena para as contorcionistas, indica uma forma de começar a pensar na resolução deste problema.

O segundo tipo de colaboração do educador no processo de desenvolvimento dos educandos (resolução da tarefa em conjunto), também pôde ser identificado no presente episódio. Após a apresentação da cena dos equilibristas com bastão, a educadora percebe que a caracterização dos personagens não ficou muito clara (não dava para perceber que um era o professor e o outro o aprendiz, conforme a intenção dos estudantes). Desta forma, ela intervém, propondo uma forma de resolução para o problema:

\footnotetext{
"Pensei uma coisa: em vez de vocês ficarem cantando a música desse jeito enquanto o Marcelo está apresentando, porque que vocês não ficam olhando assim (faz cara de reprovação)?”. (cenário 2/cena1)
}

A sugestão da educadora indica ou propõem uma forma de agir para resolver o problema da caracterização dos personagens. Não se trata da "resposta mais correta” para o problema, mas de uma resposta possível dentro das condições criadas pelos estudantes. Com essa ação, a educadora indica, também, uma forma de comunicação intencional com o público.

Este tipo de intervenção, resolvendo a tarefa junto com a criança (não a tarefa inteira, mas apontando uma forma para começar a sua resolução), está presente nas ações de uma educadora junto com os narradores (cenário 3/cena 1). Separamos o seguinte exemplo:

Narrador: a educadora sugere que eles olhem para o público, abram bem o braço e anunciem o personagem. Thales a imita. Eles fariam isto depois de brincar com o público, anunciando o personagem um no 
ouvido do outro. Para explicar como seria essa parte da cena, ela a faz com o Luan: professora cochicha a próxima atração no ouvido do Luan indicando que o Thales faria isso com ele.

Professora: “você ouviram' [para o público]? Vocês podem brincar assim. 'Vocês não ouviram?' [para o público] Daí vocês falam junto: 'Mágica!!’”, (abrindo os braços).

Durante essa cena a educadora procura construir com os estudantes um jeito de interação com o público durante as cenas de narração do espetáculo. Para isso, ela dá um exemplo de como poderiam realizar essa tarefa. A sugestão da educadora fica incorporada no personagem dos narradores, ainda que sofram muitas modificações. Podemos dizer que as falas dos narradores foram sempre alteradas (a cada ensaio), mas a organização geral e os “métodos” de interação com o público (ou talvez a forma de criação do objeto artístico) mantiveram-se: jogral, trocar palavras, pedir pro público adivinhar a próxima atração etc.

Sintetizando as análises dos episódios de ensino

I) As intervenções docentes que buscam interferir diretamente nas ações práticas dos educandos (ou em suas respostas práticas) podem caracterizar-se tanto como uma etapa no processo geral de ensino - em que o educador lança mão dessa intervenção como um recurso para que os estudantes lembrem-se de um determinado modo de ação que já tenham um certo domínio - quanto se configurar como um modo de organização do ensino em que a resolução de problemas práticos de aprendizagem, importem mais do que a apropriação do modo geral de ação contido em um determinado problema;

II) Os conceitos espontâneos ou empíricos constituem-se em ponto de partida do ensino somente para os educandos. Para o educador, os conceitos teóricos, as sínteses conceituais que os educandos deverão se apropriar ao final do ensino devem ser ponto de partida e referência, do início ao fim do trabalho, para suas ações;

III) Apropriar-se de um conceito significa não apenas ou principalmente dominar o seu termo e definição, mas, sobretudo, dominar o modo de ação presente neste conceito. Apropriar-se de um novo conceito implica numa ampliação em quantidade e qualidade das possibilidades de ações que temos em uma dada realidade. 
IV) As sínteses conceituais apresentadas pelos professores desempenham o papel não de conceitos prontos (a serem memorizados), mas de um instrumento para o trabalho dos educandos em seus processos de apropriação dos conceitos, isto é, de análises e sínteses teóricas de uma dada realidade;

\subsubsection{Os Episódios de Aprendizagem.}

Episódio 5: Relação do sujeito com o movimento humano: o movimento como ação ou operação da atividade;

Episódio 6: Relação do sujeito com a atividade criadora: criação reprodutiva e criação criativa;

Episódio 7: Formação conceitual da cena engraçada: o movimento de reflexão do conceito pelas crianças;

Episódio 8: Movimento de apropriação do ângulo de visão: o movimento das ações das crianças com o conceito;

Episódio 9: Movimento de formação do conceito de narrador: o movimento da atividade do sujeito;

Episódio 10: Relação com a finalidade da atividade: movimento como operação ou como ação e motivo da atividade.

Episódio 5: Relação do sujeito com o movimento humano: o movimento como ação ou operação da atividade.

Unidade conceitual de análise: Criação e imaginação.

CENA I: A aproximação de Luis com o movimento de malabarismo.

narração da cena:

Após as experimentações de alguns movimentos de personagens do circo (aula 3), que teve como objetivo fornecer algumas idéias de movimentos para as crianças, os educadores solicitam que a estudante Fabiana mostre os materiais de circo que 
trouxe naquela aula (chapéu de equilíbrio, fita/balangandã, pano e bolinhas para malabarismo) e os movimentos que sabia realizar com estes objetos. Após essa demonstração, as crianças envolvem-se na execução dos movimentos relacionados ao personagem equilibrista. Era um momento de experimentação dos movimentos.

Narrador: Fabiana brinca com duas bolinhas de malabares do seu kit. Luis vê Fabiana brincando com as bolinhas e aproxima-se:

Luis: “Oh Fabiana! Deixa eu fazer um pouquinho?” [Ela empresta o material]. "Você quer como, uma mão, duas mãos?"

Narrador: Luis fica brincando com as bolinhas (uma mão e duas mãos), mostrando uma certa habilidade e conhecimento sobre como fazer os movimentos de malabarismo.

CENA II: A definição de Luis como o personagem malabarista do circo.

narração da cena:

Os educadores começam a discutir e a elaborar com as crianças as divisões dos personagens para a construção do espetáculo (aula 4). Foram sugeridos dois personagens iniciais pelos educadores (os acrobatas e os equilibristas) além de outros dois que poderiam existir (mágicos e contorcionistas). A escolha dos personagens deu-se de acordo com os interesses de cada criança.

Narrador: Luis ratifica sua intenção em ser o malabarista no espetáculo, intenção essa que havia já surgido nas primeiras aulas, antes mesmo de realizar os movimentos de malabarismo.

Luis: "Eu sou o malabarista, não quero nem saber"

Narrador: Fica decidido que o malabarista passará a integrar o grupo dos equilibristas.

CENA III: A elaboração do planejamento da cena de malabarismo e os ensaios da cena.

narração da cena:

Após a divisão das crianças nos grupos de personagens, demos início (aula 4) à elaboração do planejamento das cenas. O planejamento foi precedido por uma discussão com as crianças em que os educadores apresentaram os conceitos de cada um dos elementos criadores das cenas de forma sistematizada (anexo V). Para elaborar o planejamento entregamos para cada grupo uma ficha orientadora onde eles teriam de escrever a cena que iriam fazer, orientados pelos elementos criadores trabalhados por nós (anexo I). Nesta aula, afixamos nas paredes os elementos $e$ seus conceitos correspondentes para que as crianças pudessem consultar durante a criação de suas cenas. A ficha de planejamento servia como orientador das intervenções dos educadores nas atividades das crianças e de referência para elas durante os seus ensaios.

\section{cenário um:}

Luis começa a ensaiar os movimentos de malabarismo com as bolinhas (aula 5). Uma educadora, que havia acompanhado o planejamento do grupo dos equilibristas e o planejamento do malabarista, intervém no ensaio de Luis, relembrando a idéia da cena que ele havia criado: começar engraçado, caindo uma bola na cabeça, depois 
fazer os movimentos para ficar bonito.

Planejamento (anexo II):

“eu começo jogando as bolas para o alto e sempre as bolinhas vão cair na minha cabeça e depois eu vou fazer certinho."

Narrador: Luis segue treinando os movimentos de malabarismo. Uma segunda educadora tenta auxiliá-lo no ensaio da cena engraçada (que ele havia planejado), dando idéias para ele. Ele ouve e discute as idéias, mas no momento do ensaio e estando sozinho, ele treina apenas os movimentos, não a cena propriamente dita.

\section{cenário dois:}

Nesta aula (aula 6), realizamos a primeira apresentação das cenas para os colegas e os educadores. No momento da cena do malabarista, Luis demonstra uma preocupação com a execução dos seus movimentos quando é chamado ao palco para apresentar a sua cena para todos.

Luis: “mas eu não treinei direito...” [já dentro do palco]

Prof II: "Do jeito que você treinou".

Narrador: Ele realiza a cena. A cena é basicamente a execução dos movimentos. Aquela cena planejada inicialmente ou mesmo elementos que permitissem identificar nitidamente um começo, um meio e um fim planejado da cena, estavam ausentes. No final da cena ele demonstra uma certa irritação por ter deixado cair as bolinhas muitas vezes.

CENA IV: A relação do Luis com os ensaios da cena de malabarismo: ensaio da cena ou treinamento dos movimentos?

\section{narração da cena:}

Durante a elaboração de um material para o cenário (aula 7), Luis insiste na sua necessidade e vontade de treinar os movimentos do malabarista.

Luis "Cadê as bolinhas [para professora]? Eu tenho que treinar, que eu não sei fazer direito"

Prof II: "Você está treinando em casa Luis?"

Luis "Eu parei, preciso treinar"

Prof II: "Volta a treinar em casa, porque só o treino aqui não vai dar, né?”

Luis: “Onde está as bolinhas?"

Prof II: “ Agora não é hora de treinar, daqui a pouco você treina, tá?”

Narrador: passados quase doze minutos, Luis volta a insistir:

Luis: "Que horas são?”

Alguém: "Dez e meia"

Luis: “Oh, nós não vamos treinar?!”

Narrador: passam cerca de 20 minutos de sua última fala e ele volta a insistir:

Luis [para professora]: “Cadê as bolinhas?!”

Narrador: A professora ainda diz que não está na hora do treino. Precisam fazer a tarefa do cenário. Passam-se quase 10 minutos e Luis volta-se novamente para a educadora:

Luis “Agora eu quero treinar, cadê as bolinhas?!" 
Narrador: Luis começa a treinar. Professora aproxima-se e procura orientá-lo em seu treino.

Prof II: “Quando você treinar em casa, você vai ver quantas vezes você consegue fazer, porque daí no dia da apresentação, ao invés de chegar deixar cair [as bolinhas] você para antes. Se você consegue fazer três, você faz três e para; faz mais três e para... depois faz com uma mão só”.

\section{CENA V: A desistência em fazer a cena do malabarismo.}

No penúltimo ensaio geral (aula 9) e antes de iniciarmos a apresentação das cenas para os colegas, Luis procura a professora para dizer da sua desistência em fazer a cena do malabarismo. Ele justifica que não consegue fazer os movimentos direito e, mesmo com a insistência da professora para que faça do jeito que sabe e consegue, ele se recusa a continuar a fazê-la. Luis passará a fazer a cena apenas dos equilibristas com bastão.

A unidade da atividade de ensino e da atividade de aprendizagem em nosso experimento didático foi a organização ou a elaboração de cenas circenses, criadas a partir de um determinado modo de ação. Esse modo de ação, ou orientação para a ação criadora, esteve vinculado aos conceitos dos elementos para a criação da cena: intencionalidade artística, ângulo de visão, coreografia, movimento, desenvolvimento da cena, comunicação com o público (narração), acessórios e música.

Este episódio aglutina cenas de uma mesma criança em torno do processo de construção de sua relação com o movimento ao longo da atividade de criação de uma cena para o espetáculo. Apesar das características particulares dessa cena e da própria criança em questão e talvez pelo fato de termos um caso bastante expressivo, o episódio nos permite discutir um aspecto que julgamos ser importante para a atividade de ensino e aprendizagem da educação física: a relação do sujeito com o movimento. Por um lado, o movimento pode desempenhar o papel de objetivo da atividade do sujeito (portanto, ser a ação da atividade) ou desempenhar o papel de um meio ou condição para a atividade (ser uma operação). Além disso, esse episódio nos proporcionará, também, a discussão a respeito de dois tipos de atividade criadora: a criação reprodutiva ou imitativa e a criação criativa, também discutida no episódio 10.

Ainda que no experimento didático não tenhamos colocado o movimento como objetivo do trabalho dos estudantes e em nossas intervenções tenhamos procurado colocar os educandos em ações de aprendizagem que as fizessem analisar os elementos das cenas e compor cenas a partir desses elementos, nem sempre a relação das crianças com a atividade criadora teve como foco (ou objeto) a criação da cena. Neste episódio, por exemplo, 
analisamos a relação do estudante Luis com o movimento, a partir de seu engajamento na cena do malabarismo, que revela a condição do movimento como ação em sua atividade criadora. A análise do presente episódio procurará evidenciar o processo de criação com o movimento como uma ação da atividade do estudante ou como uma operação desta atividade.

A relação do estudante Luis com o processo de criação da cena do malabarista demonstra, nesse episódio, a centralidade que tem para ele um dos elementos necessários para a composição de cenas: no caso, os movimentos. O movimento, especialmente no momento dos ensaios, é o elemento da cena que mais ocupa suas ações, tanto em termos quantitativos, quanto, e especialmente, em termos de “objeto da consciência” do estudante. Podemos observar uma relação diferente nos meninos que fazem a cena do palhaço com diabolô. Ainda que em uma aula eles realizem os movimentos de sua cena durante o tempo inteiro dos ensaios (quase uma hora), a finalidade deles é, de forma bastante explícita, construir a cena planejada, isto é, os movimentos estão presentes como um dos elementos da cena (ver episódio 10). O objeto de consciência deles, aquilo para o qual estão dirigidas as suas ações é, de fato, o desenvolvimento da própria cena, de acordo com a intencionalidade pretendida e com o desenvolvimento elaborado.

No planejamento escrito e motivado pela cena engraçada planejada pelos meninos que fizeram os palhaços com diabolô (integrantes do grupo dos equilibristas, do qual Luis faz parte, e cujo planejamento ele acompanhou), Luis conseguiu planejar uma cena propriamente dita, explicitando o seu desenvolvimento e as suas intenções com ela. Ele objetivava fazer uma cena primeiramente cômica (ao não conseguir fazer o malabarismo e deixar as bolas caírem na sua cabeça) e uma cena bonita ou “de estilo” (como eles chamavam), em que realizaria os movimentos de malabarismo corretamente (cena III/ cenário 1). Este planejamento geral da cena indica que as suas idéias estão realmente articuladas com a produção de um objeto artístico, isto é, com a produção de uma realidade artística, criada a partir dos elementos da realidade que ele dominava, mas compostos de um novo modo. Ainda que o planejamento escrito fosse bastante sucinto, a idéia da cena estava posta e poderia, em seu curso, desenvolver-se. Entretanto, no movimento de concretização da cena elaborada (ensaios e apresentações), a idéia da cena não se materializou nenhuma vez.

Por um lado, temos a elaboração de uma outra realidade, de uma realidade ou objeto que podemos chamar de objeto artístico, posto que compõe os elementos disponíveis de forma tal a construir ou esboçar uma nova realidade. O planejamento elaborado pelo estudante combinou de um modo “original” os elementos que estavam disponíveis na realidade e na experiência cotidiana do sujeito. Ainda que tal combinação tenha se dado de forma 
esquemática, podemos identificar a sua intenção na cena (criar uma cena engraçada e bonita) e o desenvolvimento da mesma (começar fazendo os movimentos errados, deixando as bolinhas caírem na cabeça e depois, fazer a cena bonita, não errando os movimentos).

Por outro lado, temos uma reprodução mais ou menos imediata da realidade cotidiana durante a execução da cena. Nos ensaios e apresentações da cena do malabarista (cenas III e IV), temos uma criação mais “de memória” do que propriamente criativa; uma criação que reproduz de forma mais ou menos igual o movimento ou a brincadeira de malabarismo que o aluno já conhecia e provavelmente praticava de modo bastante similar fora da atividade de criação de uma cena circense.

Diante deste fato podemos nos perguntar: por que isso ocorre? Por que o aluno consegue planejar uma cena, mas não consegue concretizá-la?

A questão da existência de uma atividade criadora criativa e de uma atividade criadora reprodutiva vincula-se à construção daquela resposta, mas nos parece mais importante, neste caso, discutirmos não tanto a existência desses dois tipos de atividade criativa, mas sim, o porquê dessa cisão entre o planejamento (em que se verificou a imaginação criadora) e a concretização desse planejamento (em que se verifica uma tendência maior à imaginação reprodutora).

À que atribuir, então, a existência de uma atividade criadora efetivamente criativa no planejamento da cena do malabarismo e de uma atividade criadora reprodutiva na concretização da cena do malabarismo? E como explicar o movimento desse sujeito, de nosso estudante, no processo de formação do pensamento estético-artístico?

Podemos considerar que a dificuldade na realização do próprio movimento e a necessidade de um domínio mais ou menos habilidoso do movimento de malabarismo, seja o fator central e explicativo dessa cisão entre o planejamento criativo e a concretização desse planejamento. De fato, esses elementos - o grau de dificuldade do movimento e a necessidade de um mínimo de domínio habilidoso do mesmo - devem ser considerados nessa análise. Contudo, ele não é o único e, pensamos, nem sequer o central nesse caso.

Pensando na relação que esse estudante estabelece com o movimento durante os ensaios e as apresentações, podemos dizer que o movimento ocupa, no momento da execução das cenas, o lugar de ação na atividade deste aluno e não de operação. A atividade do Luis durante os ensaios indica que seu objetivo é executar os movimentos e não "executar” a cena propriamente dita. Do mesmo modo, suas falas apontam mais para a necessidade de treinar os movimentos do que de ensaiar a cena (cena IV). Luis necessitava dos materiais para seus ensaios e mantinha uma relação mais de "treino do movimento" do que de "ensaio da cena". 
Ainda assim, precisamos explicar o porquê dessa relação estabelecida com o movimento pelo estudante. Poderíamos dar como explicação, para a questão do movimento ocupar o lugar de ação na atividade do Luis (e, portanto, de objeto de sua consciência) o fato dele se encontrar num estágio tal de execução dessa habilidade que necessitasse de todas as suas energias, atenção e esforço, voltadas para a realização do movimento. Considerando que o estudante apresentava, desde antes do planejamento da cena, um domínio relativamente grande dos movimentos de malabarismo (cena I), poderíamos refutar essa explicação. Devemos reconhecer que ele não tem um domínio absoluto da habilidade de malabarismo; não tem um movimento absolutamente autônomo. Mas devemos reconhecer, também, que ele apresenta um domínio relativamente grande desse movimento, sendo capaz de realizar seqüências de até 3 malabarismos. Neste caso, pensando na necessidade de atenção e direcionamento da consciência para a execução da habilidade, poderíamos dizer que o Luis poderia ter uma independência relativa desse foco de atenção; ele poderia utilizar a sua atenção e consciência para outros aspectos que não só, ou predominantemente, o movimento. Por exemplo, para a construção da cena propriamente dita.

Haveria, então, um segundo aspecto a ser analisado na relação do aluno com o movimento e com a cena: a questão da sua motivação e do seu motivo. Ao estabelecermos uma distinção entre motivação e motivo, procuramos tanto ressaltar a fundamentação teórica da categoria motivo, na psicologia Histórico-Cultural, em geral e na obra de Leontiev (1983; 1991), em particular, quanto ressaltar o caráter espontâneo e mais ou menos imediato/direto da motivação com relação à atividade do sujeito.

Em nossa pesquisa, o motivo que pretendíamos criar nos estudantes (a necessidade para que se engajassem na atividade) era a de conhecer e dominar as formas de organização de um espetáculo de circo, ou mais precisamente, da criação ou composição de uma cena artística circense. Pretendíamos criar nas crianças a necessidade de conhecer e elaborar conscientemente um objeto artístico.

Participar de atividades corporais pode ser, para muitos alunos (embora devemos dizer que não para todos), suficientemente motivante, ou em si mesmo motivador para a ação. Poder testar destrezas, mostrar o que sabe, aprender novas habilidades, para muitos sujeitos é suficiente para os mobilizar a realizar as tarefas propostas. Contudo, como já referido, em nosso experimento didático o que estava em jogo como centro do trabalho não era a execução dos movimentos em si mesmos. Não tínhamos como objetivo criar um “ambiente motivador” ou mesmo criar tarefas em que, de um modo ou de outro, propunham os movimentos como finalidade para o sujeito. Entendemos que a motivação refere-se a um vínculo geralmente 
imediato e relativamente espontâneo (não consciente) da criança com a ação ou com a atividade em que está inserida. E para nós, que buscávamos investigar a formação do pensamento estético-artístico, importava criar condições para que a relação da criança com a atividade e com os elementos fundamentais para a criação das cenas fossem cada vez mais conscientes para os estudantes e cada vez mais mediados pelos conceitos teóricos.

Talvez, então, possamos dizer que a relação do Luis com o movimento como uma ação e não como operação (o que lhe permitiria ter como objeto da consciência a construção da cena e não a execução dos movimentos, como o foi), deu-se menos pela dificuldade em realizar os movimentos ou mesmo pela ausência de um movimento plenamente autônomo e mais pelo caráter motivador que o próprio movimento exercia para ele. O movimento lhe propunha um desafio e um objetivo que se sobrepunham ao objetivo e aos desafios presentes na criação da cena e que pretendíamos que ele se apropriasse.

A despeito das orientações das educadoras, que no geral buscavam fazê-lo relacionarse com a cena em primeiro plano (contar quantas vezes conseguia fazer o malabarismo $e$ parar antes disso para as bolinhas não caírem no chão e poder prosseguir a cena; dar uma volta pelo palco e fazer os movimentos cada vez para um lado; fazer algumas vezes com uma mão só, já que ele tinha um bom domínio desse movimento; treinar em casa, para sentir-se mais seguro; terminar a cena de um jeito especial, abrindo os braços com as bolinhas nas mãos e agradecer; ensaiar a idéia da cena engraçada, deixando as bolinhas caírem na cabeça), o estudante não conseguiu ensaiar nenhuma vez a cena propriamente dita. Seus ensaios eram equivalentes ao treino dos movimentos.

O fato do Luis não ter treinado em casa (como indicam as suas falas na cena IV), pode nos apontar, mais uma vez, para a questão do objeto da consciência do estudante e da sua finalidade ou objetivo. $\mathrm{O}$ fato de um sujeito realizar diversas vezes um movimento não indica, por si mesmo, o modo como esse sujeito se relaciona com o movimento, isto é, se vê nele uma ação ou uma operação da sua atividade. O que nos permite pontuar essa relação é a análise da finalidade do sujeito. Vamos imaginar que um sujeito, querendo realizar uma cena de malabarismo e julgando que precise treinar mais o seu movimento, comece a exercitar essa habilidade repetidas vezes. Qual é a sua relação com o movimento neste caso? Posta assim a situação, ainda não podemos dizer a respeito de sua relação com o movimento. Por um lado, ele poderia dedicar-se a execução daquela habilidade porque sabe que é importante para o artista que faz uma cena de malabarismo dominar, muito bem, esses movimentos; por outro lado, ele pode dedicar-se à melhora dessa habilidade porque necessita de um certo domínio da mesma para levar a cabo as intenções da cena que pretende criar. 
Há, sem dúvida, uma linha bastante tênue entre uma situação e outra, na medida em que devemos encontrar na primeira situação algum grau de consciência da cena a ser criada, assim como devemos encontrar na segunda situação a idéia geral de que o artista malabarista deva dominar os movimentos. Mas a despeito da proximidade ou do diálogo entre as duas situações, há, também, algo que as diferencia de modo bastante evidente.

Na situação um, o sujeito apresenta um conceito do artista malabarista ainda inicial: “aquele que faz os movimentos bem ou com perfeição”. Diante disso, criar uma cena de malabarismo é o mesmo que executar perfeitamente os movimentos de malabarismo. E neste caso, o treino dos movimentos é o mesmo que o ensaio das cenas, o que faz com que o objetivo do sujeito esteja vinculado ao domínio e exercitação do movimento.

Na situação dois, o sujeito apresenta um outro conceito do artista malabarista: "aquele que cria uma cena com os movimentos de malabarismo”. Neste segundo caso, o treino dos movimentos é apenas uma parte do ensaio da cena. Assim como na situação um, o sujeito sabe que deve dominar de algum modo a habilidade em questão, mas sabe, também, que esse domínio pode ser relativo: ele pode dominar o movimento até certo ponto, porque haverá outros elementos que irão compor a cena e do qual ele deve igualmente se preocupar.

Na situação um de nosso exemplo, então, o sujeito vê o movimento como uma ação de sua atividade de criação da cena, de modo que criar a cena é o mesmo que executar o movimento. Na situação dois, o sujeito vê o movimento como um instrumento ou operação para a criação da cena, de modo que sua ação seja a própria criação da cena. No episódio que estamos analisando, o estudante parece se aproximar muito mais do sujeito da situação um do que do sujeito da situação dois. O estudante Luis tem muito clara a importância do treinamento do movimento para a realização da cena, mas essa importância é para ele absoluta e não relativa; o movimento não é encarado como um instrumento e, desta forma, o objeto de consciência não pode ser a cena e a sua construção, mas somente o próprio movimento. Ensaiar a cena é sinônimo de treinar o movimento e vice-versa.

Por fim, destacamos um último aspecto presente na relação do estudante com a cena que nos permite ratificar essa sua relação com o movimento como uma ação. Trata-se da desistência da apresentação da cena de malabarismo em nossa penúltima aula e penúltimo ensaio (cena V). Uma vez que criar uma cena de malabarismo estava muito próxima, para ele, de se “criar uma cena com perfeição dos movimentos de malabarismo”, isto é, uma vez que o elemento essencial na criação de uma cena era o movimento e os treinos que havia realizado não lhe permitiram atingir essa perfeição (ele tinha bastante consciência de que seus movimentos não estavam perfeitos, de que ele errava muitas vezes), a cena não lhe parecia 
mais possível e a comunicação da desistência (cena V) indica esse seu percurso e relação com o movimento e com o conceito de criação de uma cena.

Faremos dois comentários para finalizar a análise deste episódio.

Em primeiro lugar, ainda que não tenhamos observado uma mudança substancial na forma como este aluno se relacionou com a sua cena e com os movimentos e que não tenhamos conseguido modificar o motivo deste aluno em sua atividade de criação da cena do malabarista, não podemos e não estamos afirmando que seu processo de aprendizagem tenha sido nulo. O papel desempenhado pelo estudante em outros momentos da atividade de ensino e as suas falas relacionadas aos processos de análise e síntese dos elementos de composição das cenas (como no episódio 9, do ângulo de visão) indicam um movimento conceitual em direção ao pensamento teórico. Assim, a análise deste episódio restringe-se a um momento do processo de aprendizagem deste estudante em nosso experimento didático e visa discutirmos uma relação geral entre o sujeito e o movimento e não uma “condição” de aprendizagem deste estudante. Para tecermos considerações sobre o processo de aprendizagem em geral deste aluno, deveríamos analisar muito mais do que uma ou outra situação de aprendizagem vivenciada por ele. A investigação desse aspecto envolveria um outro procedimento de pesquisa.

Por fim, quando levantamos a possibilidade de um estudante relacionar-se com a cena do malabarista de forma a elaborar a generalização de que, em primeiro lugar, deve-se criar uma cena e que os movimentos serão um dos recursos de criação, devemos considerar esse tipo de generalização em processo. Isto é, talvez ele considere a criação da cena focando o elemento da coreografia, organizando a seqüência dos movimentos no tempo e no espaço, mas ainda não dê conta de articular todos os elementos entre si. O que queremos pontuar, então, é que os dois tipos de movimento conceituais mencionados por nós não são estanques, mas estão, eles mesmos, em um processo de desenvolvimento.

Episódio: 6: Relação do sujeito com a atividade criadora: criação reprodutiva e criação criativa.

Unidade conceitual de análise: Criação e imaginação

CENA I: A elaboração da cena dos diabolôs. 
Para criarem as suas cenas, organizamos as ações das crianças de modo que, após escolherem seus personagens, deveriam escrever com seus grupos a idéia que tinham para a cena. Esse planejamento seria feito a partir de uma ficha orientadora (anexo I) em que eles teriam de pensar e descrever cada um dos elementos trabalhados para a criação das cenas. As intervenções gerais dos educadores nos momentos de elaboração do planejamento referiam-se às questões da definição da intenção da cena e do seu desenvolvimento. Os personagens ficaram divididos da seguinte forma e de acordo com os interesses demonstrados pelos estudantes: grupo dos equilibristas e malabaristas; grupo dos acrobatas e contorcionistas; grupo dos mágicos.

Narrador: No início do planejamento do grupo dos equilibristas (aula 4) eles definiram três cenas: a dos palhaços diabolôs (que teria uma intenção engraçada); a do malabarismo (que teria uma intenção engraçada e bonita); a do "diabolô estilo" (que teria uma intenção de fazer os movimentos "perfeitos”). Neste momento, duas crianças iriam realizar a cena dos “diabolôs estilo": o Ricardo e o Rui. Durante o planejamento, os dois estudantes esboçaram a sua intenção (fazer a cena bonita, com os movimentos corretos) e esboçaram o desenvolvimento da cena, no que diz respeito aos movimentos que seriam elaborados.

Planejamento diabolô bonito/ estilo (anexo II):

Diabolô começa com elevador e termina jogando para o alto.

CENA II: A relação do público-criança com a cena dos diabolôs durante os ensaios.

\section{narração da cena:}

Estavam previstos, em nosso planejamento, momentos de apresentação das cenas elaboradas por cada grupo para todas as crianças e educadores. Na aula 6, demos início a essa dinâmica. Cada grupo apresentaria suas cenas para o restante dos grupos e para os educadores. A dinâmica da apresentação foi um elemento bastante importante na atividade de ensino. Neste momento e após ele, os educadores procuravam colocar os elementos de criação da cena (e os conceitos relacionados a eles) como objeto de reflexão dos estudantes. A apresentação das cenas configurou-se, assim, como um momento de análise direcionada à forma de criação das cenas e como um momento de sínteses conceituais por parte dos educadores e educandos.

Narrador:_Na apresentação dos “diabolôs estilo”, o público (crianças) comentam bastante e dão palpites durante a cena. Entretanto, suas intervenções vão quase exclusivamente em direção aos movimentos executados e não para os elementos da cena (desenvolvimento e ângulo de visão, por exemplo, elementos esses que ficaram bastante ausentes na apresentação).

Crianças: "esse movimento é legal...”

"ah, quem não sabe fazer esse movimento..."

"tenta fazer o movimento assim...”

CENA III: A relação dos estudantes-personagens com os ensaios da cena dos diabolôs.

narração da cena:

As brincadeiras com os diabolôs foram ficando cada vez mais freqüentes para algumas crianças. Mesmo não fazendo parte do grupo dos diabolôs, demonstravam interesse por 
esse movimento e, muitas vezes, traziam seus próprios diabolôs para brincarem nos momentos em que podiam durante as aulas.

\section{cenário um:}

Nesta aula (aula 8), Daniel e Otávio manifestam explicitamente os seus interesses em fazer parte da cena dos diabolôs estilo. Nas aulas anteriores, eles já haviam levado seus diabolôs e, mesmo não fazendo parte dessa cena, quando podiam, brincavam com o material.

Narrador: Durante os ensaios dessa aula, Daniel e Otávio treinam seus movimentos, cada um em um canto. Não há um movimento explícito e intencional por parte das crianças de elaboração de uma cena entre eles e entre o Ricardo e o Rui.

cenário dois:

Durante a aula 8, realizamos mais uma apresentação das cenas de um grupo para o outro. $\mathrm{O}$ grupo com a cena do diabolô estilo se apresenta.

Narrador: Rui fica o tempo inteiro de costas. Os educadores procuram chamar sua atenção para esse aspecto, mas ele raramente se posicionava adequadamente no palco (de modo que pudéssemos ver seus movimentos).

Rui e Ricardo parecem ter um desafio na cena que é jogar o diabolô um para o outro. No mais, cada um faz o seu movimento. Não há nada que nos indique, explicitamente, uma idéia geral da cena, uma seqüência planejada de ações e/ou o desenvolvimento da cena (início, meio e fim).

CENA IV: A reação do público durante a apresentação da cena dos diabolôs.

narração da cena:

Durante a apresentação, observamos a mesma relação das crianças-personagens com a cena: cada uma executando os seus movimentos, sem uma articulação muito explícita ou intencional entre si. Não é possível identificarmos de forma clara o desenvolvimento da cena (o começo, o meio e o fim da cena).

Esta cena, porém, exerce uma grande reação do público, que exclama e bate palmas quando as crianças fazem algum movimento mais difícil.

A atividade criativa ou criadora, forma de atividade que permite ao sujeito objetivar-se no mundo, tem um papel central em nosso experimento didático, na medida em que representa a atividade de criação do objeto artístico (das cenas circenses). Não estávamos preocupados em que as crianças criassem um produto artístico “excepcional”, mas sim que criassem um produto ou objeto artístico intencionalmente; que compusessem os elementos da realidade que conheciam de modo intencional e consciente. Da mesma forma, não estávamos interessados em analisar as cenas criadas pelos educandos em si mesmas, mas sim em analisar o processo de criação das cenas e o modo como os estudantes iam se relacionando com a atividade criadora, mediados ou não pelos elementos conceituais que trabalhamos com eles e 
que se constituíam, para nós, em uma referência ou modo de ação para a criação das cenas circenses.

O presente episódio aglutina as cenas referentes ao movimento de criação dos estudantes que fizeram parte do grupo dos equilibristas com diabolô. A proximidade lógica desses momentos de criação dá-se pelo caráter da atividade criativa: muito mais vinculada a uma imaginação reprodutora (a uma elaboração da cena de modo mais ou menos espontâneo, a um "criar de memória”) do que a uma imaginação criativa (a uma elaboração da cena orientada explicitamente por um ou mais elementos de criação das cenas).

A cena do diabolô "estilo", desde o início, foi uma cena elaborada quase que exclusivamente a partir da execução dos movimentos. Não houve uma intencionalidade explícita quanto à organização da cena: as formas de entrar e sair do palco, a posição no palco, a coreografia e, mesmo, a seqüência e os tipos dos movimentos que seriam realizados. A despeito de, no planejamento inicial, ter-se colocado uma seqüência de movimentos: começa “elevador”, termina jogando pro alto (cena I), os ensaios mostraram que tal seqüência não serviu de orientação para os estudantes: os movimentos realizados durante os ensaios e apresentações eram feitos, de certo modo, aleatoriamente e repetidos muitas vezes (cena III/ cenários 1 e 2).

De explícito, de intencionalidade declarada, há, apenas, a questão de se fazer os movimentos corretamente (ver cena I). Quando Daniel e Otávio passam a fazer parte do grupo (cena III) entram nesse mesmo movimento: têm como foco a realização de movimentos e não a cena como um todo. Seus ensaios mostram que eles ficam realizando os movimentos, sem muitas relações (seqüências pré-estabelecidas) ou organização entre os personagens.

As cenas ensaiadas e apresentadas pareciam ter um vínculo direto com as situações cotidianas, com o "brincar de diabolô", que as crianças já conheciam e dominavam e que muitas vezes faziam nos momentos de aula, fora dos ensaios. Tratava-se de uma reprodução mais ou menos direta de suas brincadeiras com esse material. De alguma forma, era "o movimento cru”, a habilidade em si, sem a composição de uma cena efetivamente; sem articular a esses movimentos os demais elementos artísticos que compõem uma cena e, assim, sem criar uma nova realidade, ao menos não de forma intencional, consciente e voluntária.

O que se verifica dos planejamentos e dos ensaios é que nenhum dos elementos (intencionalidade, ângulo de visão, movimento, coreografia, comunicação com o público) foram, de fato, pensados e elaborados pelos estudantes desse grupo. Em nenhum momento podemos identificar ações que nos indiquem uma intencionalidade explícita com um ou mais desses elementos. Não descartamos a possibilidade de, individualmente, cada criança ter 
pensado, de alguma forma, um plano ou seqüência de seus próprios movimentos, mas ainda assim, ainda que tenha havido esse planejamento individual dos movimentos, ele também não fica evidente nos ensaios e apresentações.

A cena dos diabolôs nos parece, assim, e dentro das cenas construídas pelas crianças, o exemplo mais emblemático desse tipo de criação a que Luria (2005) chamou de imaginação reprodutiva e Vigotsky (2004) de imaginação reprodutora. Trata-se de uma reprodução quase na íntegra dos movimentos e brincadeiras feitos com o diabolô em outras atividades, como nos horários de recreio. Trata-se de uma criação mais de memória, de reprodução da experiência vivida com esse brinquedo, do que uma criação efetivamente criadora, capaz de produzir uma realidade ou objeto artístico de forma intencional.

Dois fatos merecem destaque nesse processo, ambos relacionados ao público: de um lado o público das crianças (durante as apresentações/ensaios) e do outro o público dos adultos, durante a apresentação do espetáculo.

No primeiro dia de apresentação das cenas (aula 6), em que iniciamos a dinâmica de apresentação dos grupos uns para os outros e de análise das cenas elaboradas, as crianças (público) fazem comentários das cenas durante a própria apresentação. Os comentários relacionam-se, no geral, ao local de entrar ou sair do palco, às falas ou jeitos de terminar a cena e ao tempo da cena:

$\checkmark$ Fabiana: "Entra por ali ó” aponta o outro lado do palco, próximo à porta.

$\checkmark$ Vinícius sugere para o narrador: "Agora a apresentação..."

$\checkmark$ Crianças gritam, corrigindo a fala do narrador, que errou a ordem dos personagens: “ $e ́$ equilibrista...."

$\checkmark$ Algumas crianças começam a se queixar do tempo da cena: "demorô..." “ Ta demorando muito..."

$\checkmark$ Luis lembra o final da cena dos palhaços: "Não era de tropeçar?”

Via de regra, trata-se de comentários voltados para a própria apresentação, para a cena que está sendo desenvolvida e, de um modo ou de outro, nos remetem aos elementos de composição das cenas. Entretanto, no momento da cena dos diabolôs, as falas das crianças são todos direcionados aos próprios movimentos, não no sentido de orientar os colegas de jeitos melhores para a apresentação, mas de comentarem movimentos que sabiam ou não realizar. $O$ público, então, também tem uma relação espontânea com a apresentação, ou com o objeto artístico que está sendo apresentado, analisando-o de acordo com sua experiência imediata, vinculada à realidade não artística. Essa relação espontânea vai sendo problematizada pelos educadores cada vez que são organizados momentos intencionais de avaliação coletiva das 
cenas, fazendo as crianças analisarem as cenas a partir dos elementos e conceitos de criação das mesmas.

Esta relação espontânea do público com o objeto artístico (no caso, com a cena dos diabolôs), pôde ser observada, também, no dia da apresentação do espetáculo de circo para os pais e demais crianças do Clube, ainda que tal espontaneidade tenha se dado por outras bases.

A despeito de ter sido, como já dissemos, a cena mais espontânea do ponto de vista da elaboração consciente de um objeto artístico, foi uma das cenas que mais causou reações no público. A cada movimento “difícil” executado pelas crianças, ouvem-se exclamações de admiração e aplausos no meio da platéia. O que temos, então, é o seguinte: por um lado, os movimentos e o grau de dificuldade deles são capazes de, por si, encantar as pessoas. Isto é uma coisa. O público não sabia e não podia saber, que aqueles movimentos todos eram já de pleno domínio das crianças e que o que apresentavam ali era mais ou menos igual às brincadeiras com o diabolô durante o recreio. A execução do movimento, em si mesma, pode e causa, muitas vezes, uma relação estética do público com tal movimento. Esta dimensão é absolutamente legítima e pode, inclusive, permitir ao público um tipo de análise estética da realidade que ainda não havia tomado conhecimento: as relações estéticas presentes nas ações motoras.

Por outro lado, temos uma criação absolutamente espontânea, que ganha ares de criação não espontânea, de objeto artístico, pela relação produto/público. Do ponto de vista da formação do pensamento estético-artístico do sujeito que elabora a cena, (cena essa criada de modo não consciente e voluntário, mas cujo produto é reconhecido - pelo público - como um objeto artístico), a percepção da reação positiva do público pode levá-lo ao reconhecimento e conscientização do fim ou finalidade de uma apresentação artística. Ao ver o seu produto (a cena do diabolô) como um produto de apreciação do público (em especial, do público adulto), a finalidade da elaboração de uma apresentação (criar um objeto de apreciação para o público) pode ser conscientizada pela criança e passar a ser um elemento primário, organizador, para futuras relações e produções artísticas que realize. Nesta medida, o produto passa a ser antecipado em sua consciência, exercendo o papel de finalidade de sua atividade.

Os estudantes do grupo dos diabolôs não demonstraram durante o processo de planejamento e ensaio da cena, isto é, durante todo o processo de ensino e aprendizagem, uma relação verdadeiramente consciente com ela. Não demonstravam uma consciência e domínio dos elementos que contribuem para organizarmos uma cena, assim como da finalidade de se produzir um objeto artístico. Mas se durante o processo de ensino e aprendizagem - com a colaboração e intervenções dos educadores - essa relação consciente não pode ser 
estabelecida, pensamos que o momento da apresentação para o público - momento que revelou aos estudantes as suas ações como um produto de apreciação do público - pode ter sido, para alguns, um momento de tomada de consciência da criação de um objeto artístico. Assim, o ponto final de nosso experimento didático pode ter significado para esses estudantes (ou para alguns deles) o ponto inicial de sua atividade criadora intencional e de formação do seu pensamento estético-artístico.

Episódio 7: Formação conceitual da cena engraçada: o movimento de reflexão do conceito pelas crianças

Unidade conceitual de análise: formação de conceito

CENA I: O entendimento do palhaço como um personagem que realiza a cena intencionalmente e que necessita de muito ensaio.

narração da cena:

Durante as discussões iniciais que fizemos sobre a função e o papel do circo e sobre alguns de seus personagens (aula 2), dois meninos discutem a necessidade do treino para os personagens. Um deles reforça a idéia de que movimentos difíceis têm de ser muito bem treinados. $O$ outro estudante lembra que as cenas engraçadas também precisam de ensaio.

Rodrigo: “... o engolidor de fogo precisa treinarmuito...”

Luis: "e o palhaço, também não tem [que treinar]?”

CENA II: O entendimento do palhaço como aquele que erra as coisas de propósito.

\section{narração da cena:}

Pensando no trabalho diretamente com os conceitos de intencionalidade, elaboramos uma atividade em que as crianças, após construírem caixas com cartolinas, deveriam criar cenas engraçadas, bonitas e de suspense com as caixas (aula 3). Em um primeiro momento, os educadores sugeriam temas e situações para serem "teatralizadas". Num segundo momento, as crianças criavam livremente, apenas atendendo ao objetivo: criar uma cena engraçada/ criar uma cena bonita. Após algumas criações, uma educadora realiza um primeiro movimento de reflexão e análise com as crianças sobre o que é e como fazemos para criar uma cena engraçada.

\section{cenário um:}

Uma educadora mostra uma cena que o Rodrigo criou em um momento em que estavam em roda, conversando (ele colocava a caixa na cabeça, fingia que não a estava vendo e só percebia quando ela caia). A professora pergunta às crianças se julgam ser a cena engraçada ou não e Vinícius sintetiza sua compreensão do papel do palhaço:

Prof II: “Tem graça isso para o público?” 
Narrador: Alguns estudantes dizem que sim, outros que não. A professor pergunta o porque de cada opinião.

Vinícius [achou a cena engraçada]: "Porque ele ficou se fazendo de bobo"

Prof II: "Ele fica se fazendo de bobo para o público? Ele é bobo de verdade? Nos meninos, a caixa machucou de verdade a cabeça deles?”

\section{cenário dois:}

Durante uma das apresentações das cenas para o grupo (aula 8) os meninos do palhaço com diabolô apresentam a sua cena. Durante a cena, Marcelo faz gestos de palhaçada: andando diferente, balançando as pernas, deixando a língua para fora, desequilibrando para trás (quase caindo), dando saltinhos. Esses gestos buscavam caracterizar ainda mais a cena engraçada e passaram a fazer parte de todas as suas cenas.

Narrador: Marcelo começa a brincar com o diabolô com uma baqueta sem corda. Ele “joga” o diabolô para o alto (que permanece no chão) e fica olhando para cima, procurando o diabolô.

Marcelo: “Cadê?! Cadê?!”

Narrador: As crianças (publico) interagem com a cena: dão risada e exclamam:

“olha pro chão!”

CENA III: $O$ entendimento do palhaço como aquele que realiza a cena espontaneamente.

\section{narração da cena:}

Durante uma das avaliações coletivas das cenas apresentadas (aula 7), em que os educadores procuram colocar os elementos de criação como objeto de análise para a avaliação e sugestão das cenas apresentadas, um educador começa a conversar com as crianças sobre os jeitos de entrar no palco, explicitando a necessidade de ser um jeito planejado. Rui indica a sua compreensão do conceito de palhaço:

Prof II: "Eu tenho uma primeira sugestão, que não é só para a centopéia, porque teve outros grupos que esqueceram isso. A nossa entrada era ali, não era [aponta para a entrada do palco]? Aí eu vou entrar no palco de qualquer jeito, de costas, olhando pra baixo, como é que é? Posso entrar de qualquer jeito no palco?”

Rui: "o palhaço pode".

Prof II: "Se for a intenção pode..."

\section{CENA IV: O movimento de reflexão sobre a intencionalidade cômica.}

\section{narração da cena:}

Durante as apresentações dos colegas, muitas crianças se manifestavam durante as cenas, ressaltando erros ou acertos dos colegas. Os educadores insentivavam essas avaliações durante as cenas e, de modo mais sistematizado, ao final delas.

\section{cenário um:}

Durante a aula 6, o grupo dos acrobatas realizava a sua apresentação. No final da segunda pirâmide, a base da pirâmide sai do lugar e todos caem. As crianças todas riem da cena. Um estudante (público) faz um comentário em voz alta, possivelmente para ela mesma, que explicita seu movimento de reflexão sobre uma cena engraçada: 
Estudante: "Tem cena engraçada... eu acho...”

cenário dois:

Durante uma apresentação da cena dos narradores (aula 9), cena que era engraçada, João que fazia o papel de um dos narradores - começa a rir várias vezes durante a cena. Um estudante indica o erro de João e demonstra o seu processo de reflexão sobre a cena engraçada.

Estudante: “Oh João, você não pode rir!”

O conceito de "cena cômica" - conceito articulado ao conceito de intencionalidade da cena - foi trabalhado com os estudantes desde as primeiras aulas do curso. Antes de trabalharmos conceitualmente com essa expressão e começarmos o processo de ensino intencional do seu significado (o que se deu a partir da quarta aula), os educandos construíram cenas cuja temática ou intenção central girava em torno do objetivo de "fazer algo engraçado".

Este episódio aglutina diversas cenas que, embora não se articulem entre si de um ponto de vista do desenvolvimento dos sujeitos ou das próprias cenas, articulam-se por se referirem a um mesmo movimento conceitual: a formação ou apropriação do conceito de cena cômica. De certo modo, cada cena existente neste episódio revela um movimento particular de uma criança em direção a esse conceito. Entretanto, podemos analisar o episódio como um esboço do processo de reflexão conceitual da criança sobre o significado de "fazer uma cena engraçada”, a partir da atividade de ensino proposta e das intervenções dos educadores.

O trabalho com a intencionalidade das cenas foi bastante enfatizado durante as atividades de ensino. Nos planejamentos, esse elemento foi o alvo de maior intervenção dos educadores, juntamente com o esboço do desenvolvimento das cenas. Os educadores procuravam ajudar os educandos a definirem suas intenções (que tipo de cena queriam criar) e os modos para as concretizarem (como tornar a cena condizente com a intencionalidade pretendida).

Pensamos que o conceito de cena cômica vinculado à atividade circense, bem como os demais conceitos relacionados à intencionalidade da cena: bonita e de suspense/admiração, foi o conceito que apresentou a maior riqueza por parte das crianças em termos empíricos, comparativamente aos conceitos relacionados aos demais elementos que compõem a construção das cenas (ângulo de visão, narração, desenvolvimento, coreografia...). As crianças demonstraram em muitas de suas falas (desde as primeiras aulas) e em muitos de seus processos iniciais de construção de cenas (ainda desvinculados dos personagens) uma forte 
identificação entre circo/ser engraçado e circo/ser surpreendente. Quando discutimos, na segunda aula, os motivos que julgavam terem existido para que os homens criassem os movimentos do circo e, posteriormente, organizassem esses movimentos em forma de um espetáculo, duas questões apareceram quase como unânimes: os movimentos e o circo surgiram para "fazer as pessoas se divertirem" e para "fazer coisas descomuns, coisas que impressionassem os outros”.

As experiências que as crianças traziam sobre o circo, a maioria delas como público, revelava-se bastante rica, mas também, bastante empírica, com relação ao fenômeno e à atividade circense. As análises que faziam e os conceitos que traziam referiam-se, na sua maioria, a uma análise espontânea, de coisas que lhes chamavam a atenção, e não a uma análise que buscasse compreender aqueles fenômenos (no caso, a criação da apresentação de circo).

Não poderíamos, mesmo, esperar outra relação da maioria das crianças com esse objeto. Esperávamos, ao contrário, que justamente a organização do ensino proposta por nós, as atividades de aprendizagem propostas, que iriam permitir às crianças desenvolver uma relação intencional tanto da análise das cenas circenses, quanto da construção dessas cenas. É esperado encontrarmos relações espontâneas das crianças com relação a um determinado objeto/realidade que até então não havia desempenhado o papel de “objeto de estudo” para ela. Nossos estudantes que assistiram a alguns espetáculos de circo (conforme relatado por eles), fizeram-no sem a intenção ou o objetivo de analisar o processo de construção do espetáculo em geral e das cenas em particular. O espetáculo, podemos dizer, era percebido como um todo indiferenciado, em que aspectos mais ou menos evidentes lhes chamavam a atenção (movimentos difíceis, movimentos ou falas engraçadas, cores ou objetos das cenas etc.).

Para que pudessem estabelecer uma relação diferente com esse objeto, sua atividade deveria ser também diferente. Para que o objeto “circo" fosse tomado como um objeto de estudo, a atividade das crianças deveria ser organizada para esse fim, ou seja, elas deveriam realizar ações e tarefas que buscassem uma análise intencional deste objeto.

Neste movimento, e diante dessa finalidade da atividade de ensino, localizamos a importância das ações de análise das cenas produzidas. Após a apresentação das cenas, de um grupo para o outro, eram organizadas discussões avaliativas das mesmas, em que os educadores procuravam colocar os elementos de criação das cenas (e os conceitos relacionados a eles) como objeto de reflexão dos estudantes. Os elementos e os conceitos deveriam servir como instrumentos para a avaliação das próprias cenas e/ou das cenas dos 
colegas. Deste modo, a apresentação das cenas configurou-se como um momento de análise direcionada sobre a forma de criação das cenas e como um momento de sínteses conceituais por parte dos educadores e dos educandos.

Estabelecer uma relação intencional com determinado objeto/realidade que passará a ser o meu objeto de estudo, implica na necessidade de substituir a mediação dos conceitos espontâneos ou empíricos pela mediação dos conceitos científicos ou teóricos. Em outros termos, a relação da criança com o objeto não poderia mais ser mediada apenas pela atividade de percepções do objeto. Ao contrário, essa relação deveria ser mediada por conceitos que lhe permitisse realizar uma análise das relações e do processo de desenvolvimento do objeto em questão; que lhe permitisse realizar generalizações de generalizações, fazendo uma análise não só do objeto em si, mas, sobretudo, dos conceitos relacionados a este objeto, isto é, das múltiplas relações presentes em tal objeto.

Isso implica em um processo que passa pela apropriação dos conceitos teóricos (dos significados historicamente produzidos), pela “utilização” desses conceitos de forma mais ou menos intencional pela criança e, por fim, pela conscientização do conceito e seu uso verdadeiramente voluntário.

Com relação ao movimento geral descrito no parágrafo anterior, devemos fazer três considerações que irão perpassar a análise de todos os nossos dados referentes ao movimento conceitual de nossos estudantes.

A primeira consideração é a de que nossos dados, em sua grande maioria, não nos permitem analisar o movimento de formação conceitual de uma criança, isto é, acompanhar todo o processo de apropriação do conceito e as diversas relações entre os conceitos empíricos que trazem e os conceitos teóricos que vão formando. Entretanto, por termos diversos momentos, de diferentes crianças e por termos cada momento vinculado a um processo no movimento geral de apropriação do conceito, podemos apontar como as reflexões das crianças referentes a um conceito se articulam (ou podem se articular) com a atividade de ensino proposta.

A segunda consideração refere-se ao objetivo da análise do processo de formação de conceitos para o nosso trabalho. Por um lado, é importante analisarmos este processe de desenvolvimento para cada um dos conceitos trabalhados e que foram/são nucleares para o processo de construção das cenas circenses. Por outro lado, cada análise particular de um conceito nos proporcionará uma análise geral do processo de formação conceitual. E isto, nos parece importante. Ao analisarmos os movimentos das crianças em seus processos de apropriação de um determinado conceito relacionado à criação da cena circense, podemos ter 
uma idéia das ações de ensino necessárias para ajudar as crianças no seu percurso de aprendizagem, bem como analisarmos as relações entre os conceitos espontâneos, a atividade de ensino mediada por conceitos teóricos e o processo de desenvolvimento conceitual. Este movimento de análise nos ajudará a elaborar a conceituação do processo que estamos chamando de "formação do pensamento estético-artístico".

A terceira e última consideração refere-se ao tempo de ensino e ao tempo de aprendizagem para a formação do conceito. Pensando que a formação conceitual (verdadeiramente conceitual, o conceito teórico) não ocorre no momento em que a criança se apropria da palavra ou da definição do conceito (VIGOTSKI, 2009) e por se tratar de um processo que culmina na plena conscientização do conceito (e, portanto, no seu uso verdadeiramente voluntário, de pleno domínio da criança), podemos supor que em nosso experimento didático, os estudantes não puderam completar o processo de desenvolvimento dos conceitos teóricos, mas tão somente iniciar ou caminhar para esse processo. Não queremos dizer com isso que, para a maioria dos educandos, não tenha havido mudanças no conceito mais amplo de "criação de cena circense" e nos conceitos mais específicos relacionados a cada um dos elementos conceituais trabalhados. Pelo contrário e pelos dados de que dispomos, é possível avaliarmos muitos processos de mudanças. O que queremos dizer é que não podemos afirmar e esperar que eles tenham formado os conceitos teóricos em suas formas mais desenvolvidas, mas podemos afirmar que entraram nesse movimento de formação. A organização do ensino proposto, então, propiciou que eles trabalhassem com o objeto circo/criação de cenas de um modo não mais inteiramente espontâneo e que começassem a se apropriar dos conceitos teóricos relacionados a esse objeto. A aprendizagem proporcionada por esse ensino, embora tenha ocasionado mudanças durante o próprio processo de ensino, pode (e deverá) continuar produzindo “efeitos” nos estudantes que dela participaram (ASBAHR, 2005).

Para a análise do conceito ou do processo de formação conceitual da intencionalidade engraçada, agrupamos algumas cenas que nos remetem ou a avaliações verbais das crianças sobre esse conceito ou a momentos de criações e/ou produções de cenas envolvendo essa intencionalidade de forma explícita por parte do estudante.

Como mencionamos anteriormente, a aproximação da maioria das crianças com as cenas engraçadas deu-se desde as primeiras aulas de nosso curso. Na terceira aula, por exemplo, em que as crianças tinham como tarefa criar cenas com uma caixa, a maioria buscou, de algum modo, realizar uma cena engraçada. A única exceção foi a cena realizada pelas meninas, que não pareciam muito à vontade com esse processo de criação das cenas e 
lhes foi sugerido, por uma educadora, que criassem uma cena bonita com a caixa (realizando movimentos bonitos).

Nesta mesma aula, e por conta do andamento de uma conversa/discussão com as crianças avaliando as cenas criadas, realizamos uma primeira sistematização junto com elas a respeito do que fosse construir uma cena engraçada (cena II, cenário 1). Perguntado pela professora porque achou uma cena criada pelo colega engraçada, Vinícius conseguiu sintetizar o conceito dessa intencionalidade da seguinte forma: "porque ele [colega] ficou se fazendo de bobo".

A fala do Vinícius aponta, já, para uma compreensão e uma generalização bastante próxima do conceito, generalização essa que seria trabalhada com as crianças de forma mais sistemática a partir da aula seguinte, quando introduzimos e definimos, explicitamente, os elementos que compõem a criação da cena circense. Criar uma cena engraçada significa criar uma cena em que, intencionalmente, se erre ou exagere um ou mais elementos que compõem a criação da cena (um movimento, o jeito de entrar no palco, uma coreografia, uma fala, o ângulo de visão...). Quando o estudante Vinícius expressa a sua compreensão do conceito de palhaço ou de cena engraçada referindo-se ao fato da pessoa "fazer-se de boba", possivelmente ele tinha em mente a generalização de que o palhaço erra de propósito. Entretanto, achamos pouco provável que a compreensão desse “erro proposital” expressasse, também, a compreensão das relações entre os elementos que o palhaço poderia utilizar para errar. Em outros termos, a compreensão conceitual do aluno apresenta já uma grande generalização, mas não nos indica que se trate do conceito em sua forma final (como síntese de múltiplas relações).

Porque dizemos isso? Pensando no movimento conceitual anteriormente descrito (apropriação do conceito ou do seu significado/ ações com o conceito/ internalização do conceito) ainda que o estudante alcançasse a generalização: “cena engraçada é uma cena em que erramos intencionalmente”, provavelmente não estavam dados para ele (ao menos não de forma consciente) quais elementos poderiam ser utilizados pelo artista para errar e, assim, criar a sua cena. A voluntariedade e consciência do processo de criação da cena engraçada, passa pelo domínio desses elementos compositores da cena. E uma vez que o estudante estava iniciando o seu processo de ação consciente com a construção das cenas, nos parece pouco provável que sua fala expressasse o conceito em sua forma mais elaborada.

Um exemplo semelhante refere-se à fala do estudante Luis para o seu colega Rodrigo, argumentando que o palhaço, assim como o engolidor de fogo, precisa também treinar (cena I). 
O diálogo dos meninos começou com Rodrigo afirmando que os personagens que fazem movimentos difíceis (como o engolidor de fogo) precisam de muito treino. Luis, ao ouvir essa fala, lembra-se do personagem palhaço e questiona com certa indignação " $\mathrm{E} o$ palhaço, também não tem?!”. Esta pergunta de Luis soa mais como uma afirmação sua, do que uma pergunta propriamente dita e, neste caso, nos faz pensar que expressa sua compreensão sobre o conceito de palhaço ou, mais amplamente, de criação de uma cena engraçada.

A fala de Luis indica uma generalização ou compreensão relativamente próxima ao conceito, se não do conceito em suas múltiplas relações, de algumas dessas relações. Luis parece explicitar o entendimento de que a cena engraçada é uma cena absolutamente intencional. Ela precisa ser treinada tanto quanto as demais cenas, porque o que o palhaço faz não é apenas uma improvisação, ou melhor dizendo, aquilo que parece ser uma improvisação é fruto, na verdade, de um longo processo de trabalho. Assim, se a fala do Vinícius nos apontava para a questão da intencionalidade do erro (errar de propósito, ou fazer-se de bobo) a fala do Luis ratifica essa compreensão e nos aponta para uma segunda compreensão mais geral: o palhaço busca concretizar uma cena previamente pensada, daí da necessidade de treinar a cena.

Pensamos que neste mesmo movimento conceitual, esboçado por Luis e por Vinícius, encontra-se a compreensão de que o palhaço faz a cena engraçada para os outros. A situação que o palhaço “vive” na cena é, na maioria das vezes, não engraçada para ele (personagem) e, portanto, ele mesmo não pode rir. Esta compreensão foi externalizada por uma criança no momento da apresentação de uma das cenas dos narradores. O estudante João, durante a apresentação da cena, começou a rir por diversas vezes. Uma criança interveio: “O João, você não pode rir!” (cena IV, cenário 2). Não poder rir durante uma cena engraçada, implica em colocar em primeiro plano o personagem que está fazendo e a finalidade ou função dele na cena. A criança (o palhaço) só poderia rir numa cena, se sua risada fizesse parte dessa cena. Se a sua risada é a risada não do personagem, mas da própria criança, que estava se divertindo com a cena, ela não é legítima na apresentação. Daí da fala da criança que estava como público.

Podemos encontrar em uma outra cena deste episódio (cena III), um movimento conceitual que, de certa forma, é oposto ao movimento descrito nas cenas anteriores.

Quando a professora discutia com as crianças a necessidade de se pensar um jeito intencional de entrar e sair do palco, problematizando a necessidade de não deixar esses 
momentos descuidados, sem a nossa intenção ou planejamento, Rui expressa a sua compreensão sobre o palhaço ou a cena do palhaço.

Professora: “Aí eu vou entrar no palco de qualquer jeito, de costas, olhando pra baixo, como é que é? Posso entrar de qualquer jeito no palco?”

Rui: "o palhaço pode”.

A generalização expressa na fala do estudante pode nos indicar dois movimentos conceituais. Por um lado, ela pode expressar a compreensão de que o palhaço tem maior liberdade de realizar as suas ações. Como a preocupação dele não gira em torno de fazer uma cena bonita ou com movimentos perfeitos, ele poderia fazer qualquer tipo de movimento, poderia, no caso discutido, entrar de qualquer jeito. Supondo que a frase do Rui esteja dentro deste movimento, ainda assim, ela não está explicitamente vinculada à compreensão da intencionalidade, isto é, da não arbitrariedade da cena realizada pelos palhaços.

Por outro lado, a fala pode estar vinculada a uma compreensão conceitual explicitamente espontânea da criação do palhaço. O palhaço poderia entrar de qualquer jeito na cena, porque ele pode fazer tudo e porque ele não precisa planejar o que vai fazer. O palhaço estaria num movimento mais de improvisação do que de planejamento.

De alguma forma, podemos discutir a questão do movimento conceitual expresso por essa frase do Rui da seguinte forma: “o palhaço é o personagem que faz tudo errado” ou “o palhaço é o personagem que faz tudo de qualquer jeito”.

Difícil nos posicionarmos, apenas com essa cena, sobre qual movimento conceitual o estudante se encontraria. Importa-nos mais, agora, poder reconhecer esses dois movimentos. O primeiro indica uma consciência da intenção do personagem: ele erra de propósito. O segundo indica para uma não consciência da voluntariedade das ações do personagem: ele apenas improvisa, faz aquilo que pensa em fazer na hora.

Para finalizarmos a análise da formação do conceito da cena engraçada, analisaremos mais dois momentos ocorridos durante o nosso experimento didático, momentos esses que ilustram, em forma de ações, as discussões realizadas até aqui sobre o movimento de apropriação ou formação deste conceito.

Durante uma das apresentações realizadas entre os grupos (cena IV, cenário 1), uma criança ao deparar-se com uma cena em que ocorre um erro no movimento (a pirâmide se desmonta e todos caem), avalia a existência ou não de uma cena engraçada. Uma questão que nos parece sumamente importante nesta cena é o processo de pensamento da criança.

Quando a pirâmide se desmonta e todos caem o público em geral e esta criança em particular, riem da cena. Logo após, ela pronuncia “Tem cena engraçada.... eu acho...”. A sua 
fala parece nos indicar que ela passou a avaliar, analisar a cena, a partir de outra referência, que não só o fato dela mesma e/ou dos outros "acharem graça”, darem risada. A cena, como mostra a sua reação primária, causou-lhe graça; ela riu da cena. Entretanto, para julgar se uma cena é engraçada ou não, a criança parece ter “lembrado” que não basta apenas a sua sensação ou a avaliação da sua sensação (achei engraçado), mas a avaliação da intenção da própria cena (a razão dela ter sido engraçada). Pensamos que é neste movimento que podemos compreender o questionamento que ela mesma se colocou após a sua afirmação de que a cena era engraçada. O “eu acho” indica-nos que ela, de algum modo, se questionou sobre o porquê da cena ser engraçada. A pirâmide caiu: e isso foi engraçado na cena. Mas foi engraçado porque caíram de propósito? Ou erraram sem querer e, ainda que de forma não intencional, produziram algo engraçado? Difícil fazermos quaisquer outros tipos de inferência da fala do estudante nessa cena. Mas pensamos que um elemento importante seja o fato do educando ter se disposto a questionar as suas próprias sensações diante de uma cena, ou a buscar elementos que dessem suporte a essa sensação.

O movimento de apropriação do conceito de criação de cena engraçada passa, como dissemos, por um processo de ação externa com o conceito, antes de ele ser verdadeiramente internalizado (consciente e voluntário). Algumas cenas criadas pelas crianças indicam, em parte, esse processo de ação com o conceito e de "início” de sua conscientização. Novamente, não podemos esperar (pela forma e tempo da atividade de ensino levada a cabo em nosso experimento didático) que as crianças chegassem a uma plena formação e internalização do conceito em questão. Mas algumas cenas nos indicam que esse processo de ação mais ou menos intencional com o conceito (ou com partes do conceito) ocorreu.

Exemplos desse processo podem ser vistos nas cenas dos palhaços com diabolô (cena II, cenário 2), em que o aluno Marcelo comete erros propositais (explicitamente propositais) durante suas cenas. O planejamento da cena como um todo já trazia, em si, dois erros intencionais bastante explícitos e que se tornaram o eixo da apresentação de suas cenas: fingir jogar o diabolô para cima (o personagem achava que tinha jogado, mas o material continuava no chão) e fingir tropeçar em algo no chão e cair. Este último elemento apresenta-se, nos estudantes que fizeram o palhaço com diabolô (Marcelo e Rui), um grau tão elevado de intencionalidade que, na aula 5, elas passaram mais de dez minutos ensaiando “jeitos de cair” ou tropeçar. Em um momento do ensaio, uma educadora interveio ajudando-os a tornarem a cena mais "real” e eles se empenharam buscando cair de propósito do jeito que parecesse o menos proposital possível. 
Deste modo, podemos situar as ações e as falas das crianças em um ou outro momento do processo de formação conceitual da cena engraçada. Podemos assinalar se esse processo está mais próximo ou mais distante do conceito, isto é, se sua generalização encontra-se mais articulada aos conceitos e vivências empíricas relacionadas ao objeto ou se caminham com ajuda das generalizações teóricas. Podemos, também, assinalar se a criança age de acordo com o conceito, se o conceito serve de algum modo como mediador de suas ações, ou se ela age de modo espontâneo. Mas essas nossas indicações não nos permitem avaliar sobre o grau de consciência do conceito em si mesmo, ainda que ele seja "utilizado" apropriadamente pela criança. Isto é, talvez algumas delas operem com os conceitos, mas ainda não os tenham de forma verdadeiramente consciente ou voluntária.

Episódio 8: Movimento de apropriação do ângulo de visão: o movimento das ações das crianças com o conceito

Unidade conceitual de análise: Formação de conceito

\section{CENA I: A apresentação do conceito para os estudantes e a explicitação de uma} síntese conceitual.

\section{narração da cena:}

A primeira aproximação sistemática das crianças com os elementos de criação das cenas ocorreu em forma de apresentação e discussão dos conceitos de tais elementos (aula 4). Os educadores haviam preparado um material com as sínteses conceituais de cada elemento (anexo V) que foi apresentado para as crianças, buscando fazê-las refletir sobre tais conceitos. Durante a apresentação do conceito de ângulo de visão, uma educadora propõem uma reflexão sobre um movimento específico (o da centopéia) já realizado pelas crianças em uma aula anterior:

Prof II: "Posso dar um exemplo, também, para vocês pensarem? Vocês falaram da centopéia que a gente fez, não foi?... será que é melhor a Bruna [professora, que estava de frente para as crianças] fazer a centopéia de frente para vocês ou de lado para vocês?”

Luis: "De lado"

Alguma criança: "De frente"

Prof II: "Por que de lado Luis?"

Luis: "Porque daí mostra mais coisa, mais as pessoas (...) vai mostrar quantas pessoas têm..."

CENA II: Uma primeira síntese conceitual: “ângulo de visão é fazer a cena de frente para o palco". 


\begin{abstract}
narração da cena:
Em algumas aulas notamos falas e ações das crianças referentes ao cuidado com o ângulo de visão. Esse elemento era sempre alvo de reflexões e intervenções dos educadores no momento das apresentações para os colegas e das avaliações coletivas sobre as cenas apresentadas.
\end{abstract}

\title{
cenário um:
}

Fabiana e Bianca ensaiam a cena do contorcionismo (aula 5). Em um determinado momento, discutem a posição mais adequada para ficarem durante um dos movimentos.

Fabiana: "Não, você fica do mesmo jeito [que eu]... porque eu pensei assim, se eu ficar de costas, vou ficar de costas pro público".

Narrador: A Fabiana ficaria, então, de frente para o público, mas de costas para a Bianca. Esta ficaria atrás da Fabiana, mas também virada para o público. Antes elas estavam organizadas uma de frente para a outra, porém uma delas ficando de costas para o público. A organização do ensaio da cena e as falas das meninas indicam que elas têm em mente, como referência para organizar a apresentação, o lugar do público e a necessidade de mostrar da melhor forma possível a cena que estão realizando.

\section{cenário dois:}

Os meninos da centopéia começam a sua apresentação para a sala (aula 6). Vinícius é o primeiro e mais três crianças sentam-se atrás dele, preparando o movimento da centopéia. Quando Vinícius começa a fazer o movimento, Otávio percebe que montaram a centopéia em uma direção “errada” com relação à visão do público.

Otávio: “É pro outro lado. Tem que fazer para aquele lado, assim, ó.” [Levanta-se e vai sentar-se de costas pro público].

Narrador: Vinícius (com Luan nas costas) concorda, mas continua a cena, apenas virando o corpo. Otávio estava disposto a começar a cena novamente.

Essa nova organização da posição da centopéia fez com que a mesma não mais ficasse de costas para o público, mas de frente para ele.

\section{cenário três:}

Durante a apresentação da cena dos diabolôs (aula 6) e em um momento em que o estudante Rui fica de costas para o público, a estudante Fabiana intervém:

Fabiana: "Não dá para ver".

Narrador: Esse tipo de intervenção, lembrando os estudantes para não ficarem de costas para o público, era comum durante as apresentações, tanto por parte dos educadores quanto por parte de algumas crianças.

\section{cenário quatro:}

Vinícius, Bianca e Fabiana entram no palco para fazerem a cena da pirâmide (aula 9).

Narrador: Fabiana corrige a posição inicial do Vinícius para que a pirâmide fique de frente pro público.

CENA III: Uma segunda síntese conceitual: “ângulo de visão depende do movimento e do objetivo da nossa cena, portanto podemos ficar de frente, de lado ou de costas 


\section{para o público”. \\ narração da cena:}

Bianca e Fabiana, as meninas do contorcionismo, apresentam uma relação bastante autônoma na elaboração das cenas. Ensaiam sozinhas e constantemente chamam um educador para que vejam sua cena. A relação das meninas com o ângulo de visão esteve presente, desde o início de seus trabalhos, tanto pelas intervenções mais diretas dos educadores (sugerindo posições e formas de ficar no palco), quanto pelo caráter da cena (intencionalidade e movimentos) que criavam. Na aula 9, as ações das meninas na organização da sua posição no palco, indica uma compreensão mais elaborada do conceito de ângulo de visão.

Narrador: No começo da cena, alguma criança lembra as meninas:

Crianças: "É virado pra gente"

Bianca: “ah, é verdade!”

Narrador: as meninas retomam a cena mudando a posição. A princípio ficam de frente pro público, depois Fabiana muda a posição de Bianca e a sua própria para que fiquem de lado para o público. Esta mudança, intencional por parte da estudante Fabiana, implica em uma nova possibilidade de visão da cena por parte do público.

O conceito de ângulo de visão foi um dos elementos que, juntamente com os conceitos de intencionalidade e de desenvolvimento das cenas, recebeu uma maior quantidade e qualidade de intervenções por parte dos educadores. De certa forma, esses elementos acabaram sendo os mais importantes para a organização primária da cena, isto é, para que ela explicitasse um trabalho intencional por parte das crianças.

No início da atividade de ensino e no planejamento geral, esperávamos trabalhar com todos os elementos de criação da cena (intencionalidade, desenvolvimento, ângulo de visão, movimento, narração, coreografia, música e acessórios), mas ao longo do trabalho fomos nos centrando nos três primeiros elementos, seja por vermos neles maiores possibilidades de relação consciente das crianças com a construção da cena como um todo, seja por termos pouco tempo para aprofundarmos o trabalho com todos os elementos.

As cenas que compõem este episódio, em grande parte, encerram-se em si mesmas, isto é, poderiam ser analisadas como um episódio à parte. Entretanto, foram reunidas porque pensamos que há nelas um ponto em comum: elas indicam um mesmo movimento de formação conceitual com relação ao conceito de ângulo de visão, porém em momentos distintos dessa formação e em sujeitos e situações também distintas.

Nossos dados não nos permitem analisar o processo de apropriação desse conceito em cada uma das crianças e nem se quer para uma delas. Não temos dados que acompanhem ou mesmo esbocem esse desenvolvimento conceitual percorrido por um único estudante, mas 
temos de alguns estudantes, em momentos distintos da formação desse conceito, que podem nos ajudar a compreender a relação do estudante com a apropriação do conceito de ângulo de visão durante as suas tarefas de aprendizagem. Esse movimento nos fornecerá, também, elementos para pensarmos sobre a organização do ensino para a formação do pensamento estético-artístico.

O conceito de ângulo de visão foi apresentado pelos educadores como sendo a forma de organizar a cena (particularmente as ações ou movimentos) de modo que aquilo que quiséssemos mostrar para o público estivesse em evidência. A definição conceitual trabalhada (ou exposta) para os alunos foi a seguinte: “Ângulo de visão: colocar em evidência o objeto que se quer mostrar para o público. Permitir que o público tenha a melhor visão possível da cena que se construiu” (anexo V).

Quando apresentamos este conceito (cena I), assim como os conceitos dos demais elementos que compõem a criação das cenas, uma educadora trabalhou com as crianças um exemplo para refletirem sobre esse conceito: o movimento da centopéia. As crianças foram questionadas sobre a melhor posição para o público ver a centopéia: se feita de frente ou de lado para o público. A intensão era iniciar o movimento de análise do ângulo de visão a partir do objeto e do objetivo da cena.

Para a maioria das crianças a necessidade de saber qual era à frente do palco é bastante clara, ainda que, algumas vezes, em suas apresentações "se esquecessem” de se posicionar adequadamente no palco. Mas saber ou ter consciência da frente do palco, apenas, pode nos indicar um movimento conceitual de ângulo de visão que (se expressássemos em palavras) poderia ser o seguinte: “ângulo de visão em uma cena é fazer a cena de frente para o público”.

Muitas das falas das crianças (duas das quais transcritas aqui) demonstram esse tipo de generalização durante as cenas dos colegas: “Não dá para ver” (cena II, cenário 3), ou “é virado pra gente” (cena III). Esse tipo de generalização, ou esse movimento de apropriação do conceito pela criança, já indica um certo grau de análise da situação, ao reconhecer a importância e a necessidade de se saber a frente do palco e a posição do público, organizando a cena a partir deles. Por outro lado, ele indica, também, um certo grau de estereotipação desse conceito, sobretudo quanto à organização da própria cena. Uma vez que o ângulo de visão diz respeito a ficar corporalmente de frente para o palco, todas as minhas cenas devem ser assim direcionadas, independentemente do movimento que estou executando e das minhas intenções com a cena. A criança, neste caso, analisa o lugar em que o público fica, mas o faz 
em termos absolutos, sem relacioná-lo com o objeto a ser mostrado para o público, com a cena a ser apresentada, propriamente dita.

O exemplo exposto na cena II/ cenário 2, nos parece emblemático com relação a esse tipo de movimento conceitual. A preocupação do estudante Otávio com relação à visão do público fica explícita em sua fala e em sua ação (recomeçar a cena). Entretanto, sua análise sobre a posição das crianças para realizar a cena da centopéia, de modo a favorecer a visão do público, reside na relação ficar de frente/ficar de costas para o público. Podemos dizer que o conceito de ângulo de visão para este estudante, e neste momento, ficou fixado à "ficar de frente para o público".

Na cena I deste episódio, quando o professor propõe o exemplo da centopéia para refletirem sobre o conceito de ângulo de visão, o estudante Luis (que não fazia parte do grupo da centopéia), demonstrou em sua fala apresentar um outro movimento ou processo de apropriação deste conceito. Ele explica o porque de ser melhor fazer a centopéia de lado para o público, comparativamente a fazê-la de frente. Ele demonstra analisar não apenas a relação frente do palco/frente do corpo, mas também e, principalmente, a cena ou o movimento que se quer mostrar para o público. Nesta etapa de análise, podemos dizer que o conceito passou para um outro nível, estabelecendo relações mais complexas entre os elementos que dele fazem parte e, neste ponto, o objeto a ser apresentado para o público - e não só a frente do próprio corpo - é que passa a ser o central para a organização do ângulo de visão em uma cena. Se expressássemos essa etapa do desenvolvimento do conceito em palavras, poderíamos dizer o seguinte: "para organizar o ângulo de visão em uma cena, podemos ficar de frente, de costas ou de lado para o público, a depender do objetivo e do movimento que estamos realizando”.

Assim, o movimento e objetivo devem ser analisados conjuntamente para o processo de organização do ângulo de visão. O movimento da centopéia, para ficarmos no mesmo exemplo, não é melhor ser feito de lado em termos absolutos. Podemos organizar a cena de frente se essa organização estiver vinculada com o nosso objetivo. Do mesmo modo, posso fazer uma cena com malabarismo o tempo inteiro de costas para o público, porque quero criar uma cena engraçada. É neste sentido que precisamos analisar, conjuntamente, o movimento que vamos fazer e o nosso objetivo para organizarmos o ângulo de visão em uma cena.

A mesma relação com o conceito pode ser observada durante as cenas das contorcionistas (cena II, cenário 1). Neste momento, a estudante Fabiana muda a organização da cena para que ela não fique de costas para o público. Entretanto, essa mudança faz com que os movimentos da Bianca sejam, em parte, encobertos pelos da Fabiana, já que esta está na frente daquela. 
Em um momento posterior (cena III), durante uma das apresentações e a despeito da fala do público para que as meninas se posicionassem de frente para eles, Fabiana organiza a posição da cena de outro modo: elas passam a ficar de lado para o público. As meninas em nenhum momento verbalizam as razões de suas ações, mas fica claro que a mudança buscava um melhor ângulo de visão para o público. Ficar de lado, não as deixava de costas para o público (um problema que elas mesmas já haviam expressado, ver cena II/ cenário 1) e, ao mesmo tempo, resolvia o problema de uma encobrir o movimento da outra, o que ocorria quando ambas ficavam de frente para o público.

Ainda que nessa cena não haja uma verbalização sobre essa decisão de ficarem de lado o fato da construção da cena do contorcionismo ter apresentado diversos momentos em que as estudantes preocupam-se e discutem a posição delas no palco para a apresentação da cena, podemos afirmar que tal ação esteve vinculada ao processo intencional das contorcionistas de busca do melhor ângulo de visão para a cena, isto é, de posicionarem-se de modo a favorecer a visão do público para os movimentos que queriam mostrar.

Assim, para algumas crianças, o movimento conceitual de ângulo de visão ainda precisava alcançar o primeiro nível (a consciência da frente do palco). Para outras, o conceito de ângulo de visão, em suas múltiplas relações, entra em processo durante a atividade de estudo.

Episódio 9: movimento de formação do conceito de narrador: o movimento da atividade do sujeito

Unidade conceitual de análise: Formação conceitual

\section{CENA I: Definindo a existência de um narrador no espetáculo.}

\section{narração da cena:}

O início do planejamento das cenas foi precedido por um trabalho de discussão e apresentação pelos educadores dos conceitos de cada um dos elementos criadores das cenas (anexo V) e pela definição dos personagens que teríamos e dos estudantes que fariam parte de cada um dos personagens. Durante o planejamento do grupo dos acrobatas (aula 4), os estudantes decidiram que em suas cenas haveria um narrador, representado pelo estudante Luan. Assim, o elemento "narração" presente na ficha orientadora (anexo I) seria desempenhado por um personagem narrador.

\section{cenário um:}

Durante a aula 6, no momento em que os educadores organizam as crianças para a realização da primeira apresentação das cenas entre os grupos, uma educadora sugere ao 
Luan que ele seja o narrador das cenas dos outros grupos, isto é, que seja o narrador do espetáculo.

Prof II: "Luan, você que é o narrador do acrobata não quer narrar também a cena [ruídos]” Voltando-se para as demais crianças "Ele é o narrador do acrobata, vai ter narrador o equilibrista?"

Narrador: A maioria das crianças diz que não. No decorrer da organização desta primeira apresentação, Luan acaba aceitando o papel de narrador em todas as cenas, assim como as demais crianças concordam em ter um narrador do espetáculo. Neste momento, Luan ainda não havia preparado as suas falas.

CENA II: Os primeiros ensaios do narrador: ser narrador é chamar a próxima atração .

\section{narração da cena:}

Durante o primeiro ensaio nos grupos (aula 5), começa-se a pensar sobre a cena do narrador, sobre como ele poderia falar. Uma educadora sugere a fala: "agora como vocês, a pirâmide!". Além dessa intervenção e da aproximação do estudante Luan na busca de ajuda para pensar sua cena, não houve durante essa aula, outros ensaios da cena de narração.

\section{cenário um:}

Durante a organização da primeira apresentação das cenas dos grupos uns para os outros (Aula 6), Luan manifesta preocupação com a sua cena:

Prof II: "Cada um dos grupos vai vir aqui no palco, fazer a sua apresentação e o resto, todos nós, vamos ficar assistindo a apresentação desse grupo.”

Luan: "Mas eu não sei o que eu falo, eu sou o narrador..."

Prof II: "É isso que nesses quinze minutos você vai ter que pensar com o grupo o que você vai falar. Depois a gente melhora.”

\section{cenário dois:}

Começam as apresentações. Luan apresenta a sua cena que se configura, na verdade, como um primeiro ensaio da cena. Até então, ele não havia planejado o que falar e a cena como um todo.

Narrador: Luan está no palco para apresentar o primeiro personagem (os equilibristas). Ele fica na parte de trás do palco e diz muito timidamente "os equilibristas". Uma criança sentada no lugar do público sugere uma fala para ele

Vinícius: “Agora a apresentação...”

Narrador: Luan aceita a sugestão, mas acaba se confundindo qual era o personagem.

Luan “Tá bom... Agora a apresentação... dos acrobatas!”

Narrador: Imediatamente as crianças (público) exclamam de seus lugares: “É equilibrista!”

Luan: "Agora a apresentação dos equilibristas” e sai do palco.

Fabiana "É por lá que entra! Fica lá..."

Narrador: Luan, um pouco "irritado", da a volta pelo palco para entrar pelo local combinado e anuncia novamente os personagens. 
Luan fica, agora, atrás do palco, esperando sua vez de entrar como narrador. Em determinados momentos estuda as cenas (ordem) que estão anotadas na lousa.

Narrador: Luan entra no palco para narrar a segunda cena. Aproxima-se da frente do palco: “Agora...” Ele esqueceu o personagem que iria entrar e volta-se para perguntar para as meninas quem era. De costas para o público e dirigindo-se para fora do palco ele diz "Pirâmide e... (ruído)". As meninas lembram Luan qual será a próxima cena: centopéia. Ele, quase fora do palco, e meio de costas para o público chama:

Luan: “Agora, lá vem a centopéia”.

\section{CENA III: Ser narrador é organizar o espetáculo!}

\section{narração da cena:}

Ainda durante as suas primeiras apresentações, Luan começa a perceber uma outra função de seu papel: organizar o espetáculo. Neste momento Luan parece começar a assumir ou compreender o papel de narrador.

\section{cenário um:}

Após o término da cena da centopéia (aula 6), algumas crianças entram no palco e Luan pede para que elas se retirem.

Luan: “Agora é minha vez”.

Narrador: Novamente de costas e longe do público, Luan anuncia o próximo personagem. Luan: "Agora a pirâmide"

Narrador: As crianças e o professor o corrigem: agora era a vez do contorcionista e não da pirâmide. Imediatamente ele narra a próxima cena, da mesma forma que anteriormente: de costas e na parte de tras do palco. Vinícius mais uma vez tenta ajudá-lo e o empurra, levando-o mais para dentro do palco. Luan entra no palco para narrar a última cena do dia

Luan: “Agora, finalmente...”

Narrador: Neste momento, Rodrigo (um dos mágicos) entra no palco.

Luan: "Sai do meio!" "Finalmente os mágicos" (ele falta alto).

Narrador: O público estava fazendo um pouco de bagunça e uma educadora solicita para o Luan que narrasse novamente a cena. Os mágicos já estavam dentro do palco e Luan, mais uma vez, chama a atenção deles:

Luan: "Da licença do palco, que eu ainda nem chamei”.

\section{cenário dois:}

Durante a aula 7, enquanto as crianças preparavam materiais para o cenário do espetáculo, começa uma discussão entre alguns meninos sobre a importância ou não de vendermos ingressos para a apresentação. Luan ouve a discussão e pronuncia-se fazendo uma avaliação da função do narrador no espetáculo

Luan: "EU! Eu, eu sou o narrador, eu que devo vender o ingresso!”

\section{cenário três:}

Durante a aula 8, após ouvir de uma educadora que os ensaios terminaram e que iria começar a apresentação, Luan dirige-se para todas as crianças, ao que parece já exercendo a sua "nova" função de narrador:

Luan: “Acabou! Agora vai ser a apresentação!” 


\section{CENA IV: Ser narrador é criar uma cena para apresentar as outras cenas!}

\section{narração da cena:}

Durante os ensaios, antes da apresentação de um grupo para o outro, decide-se que o estudante Thales também fará parte da cena dos narradores (aula 8). Uma educadora acompanha o ensaio dos meninos e desempenha um papel determinante para essa cena. A educadora sugere e organiza ações que vão caracterizando a cena dos narradores como uma cena de fato (com intencionalidade, começo, meio e fim...). As sugestões da educadora ficam incorporadas nos personagens dos narradores, ainda que sofram muitas modificações pelos estudantes. Podemos dizer que as falas dos narradores foram sempre alteradas (a cada ensaio), mas a organização geral e os "métodos" de interação com o público (ou talvez a forma de criação do objeto artístico) mantiveram-se: jogral entre os palhaços; trocas de palavras (falar palavras erradas de propósito); um palhaço engraçado (geralmente alheio à necessidade de apresentar a próxima atração), outro mais sério (tentando narrar o espetáculo); interações explícitas com o público.

\section{cenário um:}

Durante um dos ensaios dos narradores com a presença da educadora.

Narrador: Luan entra no palco para iniciar uma das cenas dos narradores.

Luan: "Irrespeitável...” (entrando e olhando para o público e depois para o Thales que está chegando)

Thales: “Público!” (pulando e caindo no chão. Ele finge que machucou o joelho)

Luan: "Apresentamos"

Thales (pulando e abrindo os braços): “é... os mágicos!”

Luan faz- se de irritado: "Os...?”

Thales: "Vocês vão ter que...” (olha para Luan)

Luan: “...Adivinhar!”

Thales: "Eles não tem nariz..."

Luan: “... não tem peruca...”

Thales: “... e também não tem (afasta a perna e aponta com os dedos para os pés): sapatos grandes (fala com voz mais grossa) É o...?” (voltando-se para Luan)

Luan: "Palácio?” (baixinho)

Prof I: "pa o que?”

Luan: "Palácio" (gritando)

Thales: "É um?” (fazendo-se de irritado)

Luan: [não da para ouvir]

Thales: “é um?” (vindo pra cima do Luan)

Luan: "Idiota?"

Thales se faz de irritado: "é um?!"

Luan: "chato?"

Crianças do público brincam: “[é um ] Thales!”

Thales: "é um?!!... mas, mas...é um?!

Luan: "Palhaço" (dando risada)

Thales: [sai cantando e dançando]: "Finalmente, finalmente, finalmente, finalmente, finalmente!!”

\section{cenário dois:}

Durante a apresentação do espetáculo para os pais e demais crianças. 
Narrador: Luan entra para apresentar a cena dos mágicos e começa dirigindo-se para o público.

Luan: "Quer apostar que eu faço uma mágica?”

Narrador: Ele brinca de "fazer sumir" atrás de seu corpo uma fita crepe que estava

em sua mão. Após algumas falas e brincadeiras dele com o Thales, Luan anuncia a próxima cena.

Luan: "Apresentamos .... os mágicos (faz uma voz de mistério). Ta vendo a gente é melhor do que o que vem, muito mais!”

O conceito de narrador não foi alvo de uma intervenção intencional no ponto de partida da organização da atividade de ensino. Trabalhamos com os estudantes o elemento e o conceito de narração como sendo aquele relacionado a uma comunicação mais explícita e intencional do personagem com o público. Entretanto, ao longo da atividade de ensino, o surgimento da cena de narradores e as intervenções dos educadores na construção dessa cena nos possibilitaram analisar o movimento de um estudante na apropriação ou elaboração do conceito de narrador.

O presente episódio refere-se ao único movimento, dentro da unidade conceitual de análise de formação conceitual, que aglutina cenas de um mesmo estudante e em torno de um mesmo processo de formação conceitual: o conceito de narrador ou, mais amplamente, o papel e a função do narrador num espetáculo de circo.

As cenas que compõem este episódio nos parecem apontar para três momentos ou etapas no processo de formação do conceito neste educando, isto é, podemos identificar, de modo mais ou menos explícito, três tipos de generalizações pelo qual esse estudante passou: narrador como aquele que apresenta a próxima cena; narrador como aquele que organiza o espetáculo como um todo; narrador como aquele que elabora uma cena para apresentar as demais cenas.

Destacamos neste episódio a possibilidade de analisar o movimento de transformação conceitual da criança juntamente com o movimento de transformação da atividade na qual ela está inserida, tendo um papel muito forte aí, a colaboração de outras crianças e a colaboração dos educadores no processo de apropriação e formação conceitual do estudante.

Na quarta aula de nosso experimento didático, os estudantes se dividiram nos grupos, de acordo com os personagens que iriam representar e começaram a elaborar os seus planejamentos. Neste momento (cena I), ficou decidido que no grupo dos acrobatas o estudante Luan faria o papel de narrador. Durante os ensaios, e no momento inicial de 
planejamento, o estudante e o grupo não conseguiram pensar as falas do narrador, ainda que, em um breve momento da quinta aula, uma educadora tenha tentado ajudá-lo a pensar nas falas.

Na sexta aula (cena II, cenário 1), no momento em que a professora organizava a atividade para a primeira apresentação dos grupos entre si, Luan expressa bastante aflição: “Mas eu não sei o que eu falo, eu sou o narrador...”. A fala do estudante nos parece bastante expressiva sobre a consciência que ele tem de que o papel do narrador necessita de falas programadas. Ele quer ser o narrador, está ciente de que este é o seu papel no espetáculo, mas até aquele momento não havia conseguido planejar e ensaiar minimamente a sua cena. A apresentação, portanto, seria o seu primeiro planejamento e ensaio.

Talvez por conta da especificidade da condição da criação do Luan (o momento da apresentação ter se constituído como o momento de elaboração e ensaio da cena de narração) as intervenções dos colegas e dos professores, que buscavam ajudá-lo no seu papel, foi mais explícita ou resultou em mudanças mais evidentes nas ações de Luan. Isso nos fez notar um primeiro movimento conceitual do estudante, durante essa aula. Mas antes de descrevermos este movimento, voltemos ao primeiro tipo de generalização que o aluno demonstra ter do conceito de narrador.

Já mencionamos que o estudante era ciente do seu papel. Mas se colocássemos em palavras a generalização que ele apresentava nesse momento (e provavelmente representava o seu conhecimento inicial ou espontâneo de narrador), talvez tivéssemos algo muito próximo do seguinte conceito: “Narrador é aquele que anuncia a próxima cena”. A função do narrador num espetáculo de circo e, portanto, o papel do Luan no espetáculo que estava sendo construído, deveria ser o de anunciar as cenas que seriam apresentadas pelos colegas. Mas ainda que soubesse disso, que tivesse consciência desse papel, ele não sabia como concretizálo. Ele não havia pensado, planejado, o modo como anunciaria os personagens. Como manifestou no começo da atividade de apresentação (cena II, cenário 1) “... não sei o que eu falo”.

Esse primeiro problema ganhou uma solução geral de seus colegas (cena II, cenário 2). Luan entra no palco, demonstrando bastante timidez e anuncia simplesmente: "os equilibristas”. Antes mesmo que saísse do palco uma criança dá uma sugestão de outra fala para ele: “Agora a apresentação....”

Luan aceita a sugestão do colega para o anúncio da primeira cena e a incorpora como fala inicial de suas subseqüentes apresentações dos personagens naquela aula. Suas frases vão sempre começar com o “E agora...”. 
A apresentação segue e podemos observar Luan buscando aperfeiçoar ou concretizar o seu papel de narrador. Enquanto as demais crianças apresentavam as suas cenas Luan ficava, muitas vezes, estudando a ordem dos personagens que estava escrita na lousa. Essa sua ação, parece ratificar o conceito que tem do personagem narrador: importava mais saber a ordem das apresentações, para que ele as chamasse corretamente, do que elaborar outras falas. Melhor dizendo, a fala do narrador, neste momento, parece se confundir com o simples anúncio do nome do personagem que irá fazer a cena.

Na segunda metade da apresentação, durante a mesma aula (cena III), podemos notar que ele começa a generalizar um outro aspecto do papel do narrador. Novamente, expressando em palavras esse seu outro movimento conceitual, poderíamos dizer o seguinte: "Narrador é aquele que anuncia a próxima cena e que organiza todo o espetáculo”.

Repetimos a primeira definição conceitual, apenas acrescida da preposição $e$, pelo fato de pensarmos que neste momento o estudante teve um movimento conceitual apenas de acréscimo de mais um elemento. O conceito anterior que ele trazia, não só se manteve, como parece ter se mantido sem muitas modificações. O que houve, então, neste outro processo, foi a incorporação de um segundo elemento ou generalização: o narrador tem o papel de organização do espetáculo como um todo.

Esse processo parece estar materializado em algumas frases, em que o estudante expressa o seu papel orientador do momento de entrada no palco dos demais personagens: “ $d a$ licença do palco, que eu ainda nem chamei” (cena III/ cenário 1); em que ele expressa o seu papel organizador do espetáculo: “Acabou [o ensaio]! Agora vai ser a apresentação” (cena III/ cenário 2); e em que ele amplia o seu papel de organizador do espetáculo: “EU! Eu, eu sou o narrador, eu que devo vender o ingresso” (cena III/ cenário 3).

Mas além dessa simples ampliação do conceito de narrador Luan parece passar, na oitava aula, por um processo de mudança da sua compreensão a respeito do personagem narrador (cena IV). Dois fatos são decisivos para isso e mudam, de forma bastante evidente, a atividade de narrador do espetáculo. O primeiro fato é a entrada de um segundo estudante para fazer a cena de narração com o Luan. O segundo fato é o acompanhamento sistemático de uma educadora durante o re-planejamento e ensaio da cena dos narradores. Assim, a narração em dupla proporcionou outras possibilidades de ações para o Luan, da mesma forma que a colaboração do educador ampliou e criou novas possibilidades de ações para a cena dos narradores.

A intervenção da professora, realizando o ensaio junto com as crianças e proporcionando que elas fizessem análises e generalizações sobre idéias para as cenas, 
permitiu que identificássemos uma certa “metodologia” da cena dos narradores, a despeito de encontrarmos muitas modificações de “conteúdo" em cada um dos ensaios e apresentações. Fazer a apresentação como um “jogral”; falar palavras intencionalmente erradas; ter momentos de interação explícitos com o público; ter um palhaço "mais escrachado”, que foge da tarefa de apresentar o espetáculo e outro "mais certinho", que procura apresentar corretamente a próxima cena, são exemplos de aspectos invariáveis, que surgiram a primeira vez no ensaio junto com a professora (cena IV/ cenário 1).

Este movimento todo na atividade do Luan como narrador e por conta da análise que fazemos de sua própria atividade, das cenas que apresenta e de seus ensaios, a partir da aula 8, nos permite afirmar que ele passou para um terceiro tipo de generalização sobre o papel do narrador, que expressaríamos da seguinte forma: "Narrador é aquele que faz uma cena para anunciar a próxima cena”. A mudança, agora, parece bastante significativa.

Esse novo movimento conceitual não nega, os movimentos anteriores. Mas, também, não os incorpora apenas como uma soma. Desta vez, as generalizações que ele havia construído anteriormente são incorporadas, por superação, no novo conceito. A terceira generalização é uma síntese das duas anteriores, formando uma nova qualidade conceitual.

Assim, observamos um duplo movimento: a mudança na atividade de narração proporcionada, em especial, pela intervenção e colaboração da educadora, mas também pela intervenção e colaboração do estudante Thales, permitiram uma nova síntese conceitual sobre o papel de narrador para o Luan. Por outro lado, essa nova generalização permitiu uma mudança na relação e nas ações do Luan com a atividade de criar a cena dos narradores. Permitiu que ele começasse a se relacionar de forma mais consciente com os diversos elementos para a criação das cenas (ângulo de visão, comunicação com o público, desenvolvimento...), já que, agora, o seu objeto de consciência, a sua ação, deixa de ser o simples anúncio dos personagens (a ordenação deles) e passa a ser a construção de uma cena propriamente dita (cena IV/ cenário 2). 
Episódio 10: Relação com a finalidade da atividade: movimento como operação ou como ação e motivo da atividade.

Unidade conceitual de análise: motivo e motivação

CENA I: A elaboração da cena dos palhaços diabolôs: consciência da finalidade da cena e das ações para as concretizar.

narração da cena:

Durante o planejamento das cenas, realizado a partir das fichas orientadoras (anexo II), o grupo dos equilibristas dividiu seu planejamento em três cenas: a cena dos palhaços com diabolô; a cena dos diabolôs "estilo" e a cena do malabarista.

\section{cenário um:}

Após as aulas destinadas para os planejamentos das cenas, o grupo dos palhaços produziu o seguinte Planejamento:

"Nós vamos entrar com a baqueta sem corda por dentro do casaco em um bolso interno $e$ a outra baqueta com corda levando o diabolô; dar uma volta no diabolô e fingir que vai jogar, e depois nós ficamos olhando para o céu e olhamos para o chão e o diabolô está lá, aí nós aprendemos a jogar. Aí a gente joga e quando pega, tropeça e cai”.

\section{cenário dois:}

Os palhaços com diabolô (Rui e Marcelo), após terem elaborado seus planejamentos, começam os ensaios da cena (aula 4 e 5). Os meninos não haviam levado os materiais para o ensaio, mas faziam a cena fingindo que tinham os materiais (mímicas). Em determinado momento, começaram a ensaiar a parte final da cena (o jeito como ela iria terminar): ambos caindo no chão, fingindo que tinham tropeçado.

Narrador: Rui ensaia a sua "queda” com um tropeço de mentirinha. Marcelo passa a treinar a queda também.

Narrador: Professora intervém no treino dos meninos, sugerindo algumas idéias para a queda parecer "mais real".

Prof II: "Mas vocês têm que ficar olhando para cima..."

Narrador: Marcelo finge que está jogando o diabolô para o alto e que vai pegá-lo (fica olhando para cima) daí tropeça e cai.

\section{CENA II: A criação de uma nova ação para a cena dos palhaços.}

\section{narração da cena:}

A educadora se fasta e os meninos passam a se envolver em outro aspecto da cena: o que aconteceria após a queda deles, acrescentando mais um elemento na finalização da cena, que não havia no planejamento inicial (aula 5). Este novo elemento articulava-se com a intenção central deles de fazer uma cena engraçada.

Narrador: Marcelo "tropeça” e cai no chão com as pernas levantadas. Rui aproxima-se e começam a nova ação da cena: ele abaixa as pernas de Marcelo que, ao mesmo tempo, levanta os braços. Rui, então, vai para trás de Marcelo e abaixa os seus braços. Ao mesmo 
tempo, Marcelo levanta a perna. A cena repete-se assim...

CENA III: Brincando com as ações criadas pelos palhaços diabolôs.

\section{narração da cena:}

Durante o ensaio desse novo movimento para a cena dos palhaços (aula 5), os meninos da cena da centopéia (que até então estavam brincando de correr e perseguir uns aos outros) vêem a cena dos palhaços diabolôs e imediatamente começam a brincar com os movimentos feitos pelos palhaços (de abaixar as pernas e os braços de alguém deitado no chão). Eles brincam um pouco com este movimento e depois continuam a brincar com outros: perseguir um ao outro e realizar o movimento da centopéia.

Para analisarmos o motivo do sujeito em uma atividade precisamos analisar aquilo para que estão direcionadas as suas ações. A unidade da atividade de ensino e da atividade de aprendizagem em nosso experimento didático foi a organização ou a elaboração de cenas circenses, criadas a partir dos modos de ação vinculados aos elementos de criação das cenas: a intencionalidade artística; o ângulo de visão; a coreografia; o movimento; o desenvolvimento da cena; a comunicação com o público (narrador); os acessórios; a música.

Este episódio parece ser bastante significativo para analisarmos a diferença de objetivos (ou finalidade) dos sujeitos durante a atividade de criação das cenas circenses. Discutiremos o papel de motivo para o sujeito, bem como o papel que o movimento (a ação motora) desempenha em sua atividade: movimento como operação ou como ação (discutido, também, no episódio 5), buscando relacioná-los com o fim ou a finalidade consciente do sujeito.

Os estudantes Rui e Marcelo fizeram a brincadeira de abaixar as pernas/levantar os braços e abaixar os braços/levantar as pernas (cena II), pensando em uma forma de continuar a cena que estavam elaborando e ensaiando. Depois que o Marcelo caísse no chão, ao tentar pegar o diabolô jogado para o alto, ele ficaria com a perna para cima. Rui tentaria abaixar a perna dele, mas, nesse momento, Marcelo levantaria os braços e assim sucessivamente. A brincadeira, portanto, fazia parte da "história da cena" e da intencionalidade da mesma (ser engraçada), conforme planejado pelos meninos (cena I).

Quando Thales, Daniel e Otávio vêem a brincadeira dos meninos palhaços passam a fazê-la entre si. Nada indica, entretanto, que essa brincadeira se articule minimamente com a cena da centopéia (no ensaio da centopéia a brincadeira com o movimento se sobrepôs à construção da própria cena). Assim, os meninos acrobatas repetem algumas vezes a ação criada pelos palhaços e logo depois, começam a se envolver em outras brincadeiras (lutinhas, 
perseguir um ao outro, fazer o movimento da centopéia). A intenção dos meninos que fazem a cena da centopéia ao reproduzir aqueles movimentos feitos por Rui e Marcelo está muito mais próxima da intenção de "brincar com os movimentos” do que de treinar ou criar a sua própria cena com aquele novo movimento.

Ainda que Rui e Marcelo tenham abandonado esta idéia nos próximos ensaios, ela estava, efetivamente, articulada (direcionada) com a finalidade da cena: produzir uma cena engraçada e um jeito de finalizá-la. O novo movimento é incorporado durante todos os ensaios dos meninos, como parte integrante da cena, naquele dia.

Como explicar essa diferença na relação dos estudantes com esse mesmo movimento ou seqüência de movimentos? Ou como explicar diferentes relações do sujeito com o movimento?

Já mencionamos, na análise do episódio 5, que o movimento pode exercer para muitos sujeitos um papel motivador, fazendo-os realizá-los pelo prazer de testar novas habilidades e/ou mostrar as que já domina. Mencionamos, também, que em nosso experimento didático o que estava em jogo como centro do trabalho, como objeto de ensino e de aprendizagem, não era a execução dos movimentos em si mesmos, mas a apropriação do pensamento estéticoartístico, a criação de um objeto artístico (a cena de circo).

A finalidade proposta nas atividades de ensino e necessária de ser conscientizada pelos educandos, era a de criar uma cena de circo, o que implicava num domínio de diversos elementos e conceitos vinculados a esta criação: a intencionalidade (que tipo de cena eu quero fazer e que tipo de relação quero que o público estabeleça com a minha cena); o ângulo de visão (jeitos de me posicionar no palco para que minha cena fique o mais favorável possível para a visão do público); a coreografia (jeitos de me organizar no palco, no tempo e no espaço); os movimentos (os tipos e seqüências) e o desenvolvimento da cena (um começo, um meio e um fim). Assim, para criar uma cena e o espetáculo como um todo, não bastava realizar (ainda que se realizasse muito bem) os movimentos executados pelos personagens do circo. Era preciso ter como finalidade a criação da própria cena, ter como foco do trabalho ou objeto da consciência a criação da cena, o trabalho intencional com os elementos que compõem a cena. A consciência da finalidade serviria, então, de guia ou referência durante todo o processo de criação.

Deste modo, o que podemos observar de distinto entre os dois grupos de estudantes (o dos palhaços e o da centopéia) no que se refere a suas relações com o movimento, é justamente a finalidade de cada um, ou o objetivo (motivo) para engajarem-se na atividade. Os palhaços demonstram, nas suas relações com os movimentos e com o processo de criação 
da cena como um todo, que a finalidade almejada é a de criar uma cena previamente planejada por eles. Há, para eles, um objetivo explícito e consciente de criação da cena.

Os estudantes que realizam a cena da centopéia demonstram, nas suas relações com os movimentos e com o processo de criação da cena, que a finalidade almejada é a de realizar os movimentos do personagem. E realizá-los não com o mesmo fim observado no estudante Luis (episódio 5), isto é, não com o fim de aperfeiçoar o movimento para a apresentação, mas com a finalidade de brincar com o movimento. Nos planejamentos e ensaios da cena da centopéia, não há quase elementos que nos indiquem uma organização e uma intencionalidade explícita na elaboração da cena; não há como identificar uma utilização verdadeiramente consciente e voluntária dos elementos anteriormente mencionados e necessários para a criação das cenas.

Uma vez que o que temos são finalidades diferentes quanto à atividade de criação da cena, uma vez que para o grupo de estudantes dos palhaços o fim ou o objetivo da atividade é a própria criação das cenas e para o grupo de estudantes da centopéia o fim ou o objetivo da atividade é a realização dos movimentos para se "divertirem", podemos esperar que o movimento (a ação motora) desempenhe papéis distintos nas duas atividades.

Utilizando-nos dos termos leontievanos, podemos dizer o seguinte: para o grupo dos palhaços, o movimento ocupa o lugar de operação em sua atividade, isto é, serve como um instrumento para a concretização de seu fim (construir a cena dos palhaços com diabolô). Neste caso, ainda que os estudantes precisem e devam focar suas atenções na realização dos movimentos, o objeto de sua consciência, aquilo para que está voltada a sua atividade, não é o movimento em si, mas a cena como um todo. Sua ação é a elaboração da cena.

Para o grupo da centopéia, o movimento também ocupa o lugar de operação da atividade, mas neste caso a ação é outra: brincar. Brincar constitui-se no objetivo para o qual a atividade das crianças se dirige. Ainda que os estudantes tenham uma idéia da necessidade de criar uma cena da centopéia, o objeto de suas consciências não é a cena propriamente dita (e os elementos que dela fazem parte), e nem o movimento (melhorá-lo e, portanto, conscientizar-se dele), mas a realização ou execução dos movimentos como brincadeira. As ações deles não se dirigem para os elementos e para a criação da cena, mas sim para a execução de brincadeiras. Deste modo, para um grupo o motivo da atividade é a criação da cena; para o outro, é a realização de brincadeiras com os movimentos.

Em virtude dessas diferentes relações dos sujeitos com a atividade (dos diferentes motivos ou finalidades) e, conseqüentemente, das diferentes relações que estabelecem com o movimento, a brincadeira de "abaixar as pernas e os braços do colega”, possui uma relação tão distinta na atividade do grupo dos palhaços e na atividade do grupo da centopéia. Para um 
trata-se de um elemento da criação da cena; para o outro, um elemento para a realização de brincadeiras, estas sem vinculação direta com a cena.

Ao estabelecermos essas duas formas de relação do sujeito com o movimento (relação essa estabelecida pelo objetivo ao qual o movimento se vincula) e pensando que é necessário organizar, no interior do trabalho escolar, esse processo de transformação do movimento como ação para o movimento como operação consciente, algumas questões sobre a organização do ensino poderão ser tecidas com base em nossos dados e na análise deles. Tais considerações estão relacionadas à finalidade da disciplina da educação física na escola, que está muito mais no trabalho com o movimento como operação (e na sua constituição como operação consciente) do que como ação, isto é, está mais em permitir que os estudantes trabalhem com as atividades que envolvam determinados movimentos, que pensem sobre as próprias atividades, que tenham como objeto da consciência tais atividades, do que com o trabalho diretamente com os movimentos. No caso de nosso experimento didático, a possibilidade de relacionar-se com a atividade circense em primeiro plano, ainda que o domínio consciente do movimento também tenha estado presente, implicou na possibilidade de cada estudante apropriar-se e dominar os conceitos relacionados à criação de um objeto artístico circense. E esta apropriação, nos parece fundamental para a formação do pensamento teórico no campo das atividades artísticas, para a formação do pensamento estético-artístico.

\section{Sintetizando as análises dos episódios de aprendizagem}

I) A relação do sujeito com o movimento, com a ação motora, pode desempenhar o papel tanto de um objetivo da atividade do sujeito (portanto, ser a ação da atividade, aquilo para o qual está voltada a sua atividade), quanto desempenhar o papel de um meio ou condição para a atividade (ser uma operação da atividade, um instrumento para a realização de uma determinada ação). No primeiro caso, o objeto de ação do sujeito, e objeto de sua consciência é o movimento ou a brincadeira em si; no segundo caso, passa a ser uma outra atividade (a criação de uma cena, por exemplo).

II) O desenvolvimento da criatividade criativa ocorre no movimento do sujeito de apropriação e domínio dos elementos que lhe permite criar um novo objeto, uma nova realidade. Em nosso caso, o domínio dos elementos de criação das cenas (conceitos e modos de ação) permitia aos sujeitos uma maior liberdade e consciência no processo de composição de um objeto artístico circense. 
III) É esperado encontrarmos relações espontâneas das crianças com relação a um determinado objeto ou realidade que até então não havia desempenhado o papel de “objeto de estudo” para ela. A organização do ensino em forma de atividade de estudo é o que permite às crianças desenvolverem uma relação intencional de análise de um objeto, bem como uma relação explícita com os conceitos teóricos relacionados ao objeto em questão. No trabalho escolar, a mediação conceitual na relação da criança com o objeto deve passar da mediação empírica para a mediação teórica.

IV) É possível identificar um movimento de apropriação dos conceitos teóricos por parte das crianças, que vai das generalizações da realidade pautadas na evidência ou consciência de um dos elementos presentes no conceito, (o conceito é identificado apenas com um de seus elementos, formando conceitos esteriotipados ou mais bem pseudo-conceitos) à uma generalização em que o conceito é compreendido já no movimento ou relação entre seus elementos (síntese dos elementos). 


\section{AS SÍNTESES DA PESQUISA: O PROCESSO DE ORGANIZAÇÃO DO ENSINO PARA A FORMAÇÃO DO PENSAMENTO TEÓRICO.}

O processo de organização do ensino para a formação do pensamento teórico nos educandos constituiu-se no objeto central de nossas investigações e sobre ele nos debruçaremos nesse momento de síntese de nosso trabalho. Para concretizarmos esse objetivo, lidamos durante a pesquisa com uma forma específica ou uma expressão particular do pensamento teórico: o pensamento estético-artístico. Este recurso deu-se tanto pelo interesse em investigar as particularidades do pensamento teórico que se formam ou podem se formar por meio da apropriação das atividades humano-genéricas relacionadas à arte - interesse esse vinculado a nossa área de conhecimento específica, a educação física - quanto pelo entendimento da necessidade de se estabelecer um objeto concreto para investigar o pensamento teórico em geral. Embora o pensamento teórico seja uma função psíquica genérica, ele se forma sempre como expressão de um determinado objeto, de uma determinada atividade humana.

Procuramos demonstrar que os conceitos teóricos e o próprio pensamento teórico representam o máximo de aproximação da realidade por parte dos sujeitos, a despeito de sua aparência de distanciamento da mesma. Como vimos, por um lado, os conceitos nos afastam empiricamente da realidade, nos afastam da riqueza empírica, ou mais bem, perceptiva da realidade. Por outro lado, e isto é o mais importante, os conceitos nos aproximam da compreensão da essência de uma dada realidade ou fenômeno, permitindo a compreensão das múltiplas relações existentes nela e que não nos são acessíveis diretamente, via percepção do objeto.

Por nos permitir um conhecimento para além da aparência, para além da relação direta ou imediata com o objeto e por, assim, permitir uma nova qualidade na relação do sujeito com o objeto (uma nova qualidade nas possibilidades de suas ações), defendemos ao longo desta pesquisa a centralidade dos conceitos teóricos e da formação do pensamento teórico no trabalho pedagógico que se dá na escola.

Para investigarmos, justamente, esse processo de organização do ensino para a formação do pensamento teórico, isto é, os modos de ação docente possíveis e/ou necessários para esse fim, organizamos um experimento didático em que pudéssemos acompanhar esse processo. Não estava em questão comparar formas diferentes de organização do ensino (o que exigiria um outro desenho do experimento). O objetivo estava em acompanhar o processo 
didático de elaboração e efetivação de uma proposta de ensino explicitamente ou conscientemente voltada para a formação do pensamento teórico nos educandos. Deste modo, procuramos analisar a singularidade de uma proposta pedagógica em seus aspectos genéricos e relacionados a sua organização para a formação do pensamento teórico nos escolares.

Os resultados de nossas análises, tanto a partir do plano de ensino, quanto dos episódios de ensino e de aprendizagem, nos apontaram para a existência de um modo geral de ação docente referenciado na teoria histórico cultural ou para o esboço de uma base teóricometodológica para a organização do ensino. A base teórica reside, sobretudo, nos princípios didáticos presentes na teoria histórico-cultural. A base metodológica reside nas ações de ensino pautadas a partir daqueles princípios didáticos. Como afirmamos ao longo de nosso estudo, o modo de ação geral para o trabalho docente esboçado aqui, ou esse modo geral de organização do ensino para a formação do pensamento teórico, não se inicia nem muito menos termina neste trabalho. Situamos nossa pesquisa, simultaneamente, como uma aproximação inicial aos princípios educativos e didáticos presentes na teoria histórico-cultural e como uma continuidade no diálogo que vem sendo estabelecido com essa teoria, particularmente por meio do conceito de atividade orientadora de ensino, desenvolvido pelo GEPAPe.

Autores como Rubtsvov, Galperin, Talizena e Davidov, de certo modo, se debruçaram mais concretamente sobre o processo de organização do ensino e precisam ser estudados e sistematizados em suas elaborações teórico-metodológicas. Do mesmo modo, os autores da teoria histórico-cultural com quem mais de perto dialogamos ao longo deste trabalho, notadamente Vigotski e Leontiev, precisam também ser estudados em suas elaborações teóricas, sobretudo no que tange à totalidade de suas teorias. Quaisquer conceitos elaborados por esses autores precisam ser compreendidos em suas múltiplas relações, isto é, como componentes da totalidade da obra do autor, o que nos permitirá compreender de modo mais efetivo as potencialidades teórico-metodológicas para a organização e investigação do ensino.

Procuramos analisar o papel das sínteses conceituais fornecidas pelos educadores no processo de apropriação de um conceito pelo estudante. Como procuramos demonstrar a partir dos estudos de Vigotski (2009) e a partir de nossos próprios dados, a apropriação de um conceito não termina quando da apresentação de seu termo e de sua definição; pelo contrário, aí apenas inicia-se. Deste modo, as sínteses conceituais são elementos fundamentais do processo de ensino, constituindo-se como instrumentos fornecido e organizado pelo educador para as ações dos estudantes com o referido conceito. 
Procuramos analisar, também, que a despeito de seu caráter altamente abstrato, os conceitos possuem uma dimensão concreta na vida dos sujeitos, posto que implicam (ou devem implicar) numa mudança de suas ações. Apropriar-se de um conceito significa, necessariamente, apropriar-se de um modo geral de ação. Um novo conceito significa uma nova forma de ver o objeto (penetrando em suas relações fundamentais, ou essenciais) e, simultaneamente, uma nova forma ou possibilidade de agir com ele. O conceito que não foi capaz de transformar o sujeito, ainda não foi um conceito efetivamente internalizado.

Como vimos, a arte aproxima-se do pensamento teórico na medida em que busca analisar um objeto ou fenômeno artístico revelando sua essência (os elementos que são essenciais em uma dada realidade) e buscando com eles elaborar uma nova síntese (a produção do objeto artístico). No caso da arte, os processos de análise e síntese da realidade estão ligados a uma intencionalidade geral de produzir o belo (o belo-belo; o belo-engraçado; o belo-suspense etc) via composição intencional por parte do artista dos elementos da realidade que lhe permitem materializar sua intenção.

O processo de criação artística percorre um movimento que vai da relação espontânea com a criação a uma relação consciente ou intencional, isto é, do reconhecimento e/ou reprodução mais ou menos direta de ações belas, que causam graça ou beleza (por exemplo) para a produção intencional e consciente dessas mesmas ações. Neste processo, o sujeito pode desenvolver a capacidade de separação dos elementos que compõe um determinado fenômeno artístico (abstrai do todo determinados elementos) e a capacidade de utilizar essas abstrações para a criação de um novo objeto ou objeto artístico (síntese).

Em nosso experimento didático, procuramos organizar o processo de apropriação dos conceitos relacionados à atividade circense de modo que os mesmos contribuíssem para que os estudantes formassem o pensamento estético-artístico; desenvolvessem o pensamento teórico (análise e síntese da realidade), na esfera das atividades artísticas.

Os elementos de criação das cenas (as abstrações) e a síntese desses elementos nos processos de criação e/ou avaliação das cenas circenses constituíram-se em ações que nos permitiram evidenciar o processo de ensino e de aprendizagem dos conceitos teóricos no campo das atividades artísticas.

Para tal, tínhamos como pressuposto tanto a necessidade de sistematizar maximamente os conceitos para os educandos, quanto a necessidade de organizar o ensino para sua apropriação. Os elementos essenciais de uma dada realidade ou objeto não podem ser descobertos “por acaso” pelos estudantes; não pode ser um processo espontâneo. Consideramos que os conceitos e a unidade fundamental de um objeto de ensino, dadas as 
suas importâncias para a apropriação do próprio objeto em questão, devam ser alvos diretos e intencionais das ações dos estudantes; devam ser conscientemente organizados pelo educador em forma de ações de aprendizagem discente. Neste sentido, os estudantes devem se aproximar do objeto de estudo a partir do princípio geral do processo de apropriação do conhecimento: caminhando do abstrato ao concreto (KOPNIN, 1978). No caso de nosso experimento didático: do estudo dos elementos de criação das cenas e seus conceitos (das abstrações conceituais) para a criação efetiva de cenas com os personagens circenses (para os modos de ação do artista circense). Ou nos termos de Rubtsov (1996), dos problemas de aprendizagem para os problemas prático-concretos.

No início do processo educativo, os estudantes realizavam, em sua maioria, uma análise espontânea do "objeto circo", uma análise sobre "as coisas que lhes chamavam a atenção” e não uma análise que buscasse compreender aquele fenômeno (no caso, a criação da apresentação de circo). Era esperado encontrarmos relações espontâneas das crianças com um fenômeno que, até então, não havia desempenhado o papel de “objeto de estudo” para elas. As atividades de aprendizagem propostas é que permitiriam aos estudantes desenvolver uma relação intencional de análise das cenas circenses, bem como uma relação intencional com a construção dessas cenas. Isto é, o processo de apropriação dos conceitos referentes à atividade artística circense é que lhes permitiria modificar seus modos de ação, tanto como público (análise das cenas), quanto como artistas (composição das cenas).

O ensino organizado a partir dos conceitos teóricos permite, assim, que as relações essenciais do objeto sejam evidenciadas para os estudantes e se constituam no próprio objeto de suas ações. Em outras palavras, a relação do sujeito com o objeto passa a ser mediada pelos conceitos teóricos de tal objeto. O estudante passa para uma nova qualidade de generalização do real.

Esse processo de aprendizagem pressupõe que o educador tenha os conceitos teóricos presentes como ponto de partida de suas ações docentes. Para o educador, o estudo não é uma Atividade no sentido atribuído por Leontiev. O estudo constitui-se, para o docente, em uma ação de sua atividade de trabalho (atividade de ensino), mas uma ação fundamental para a realização de sua atividade, posto que é através dessa ação que o professor pode se apropriar teoricamente dos objetos de ensino que deverão ser trabalhados com os educandos.

A apropriação da atividade artística permite tanto a formação do pensamento teórico em geral (pelos processos de análise e síntese teóricas da realidade), quanto uma maior aproximação da própria arte, penetrando em sua essência e dominando conscientemente os seus processos de criação. Entretanto, a vinculação da arte com a formação do pensamento 
teórico, assim como a relação da ciência com o pensamento teórico, não é direta e espontânea. Não basta ao sujeito “observar” ou mesmo “agir” (utilizar técnicas) com os objetos artísticos para formar o pensamento teórico. É preciso observar e agir de um modo especial; conseguir nessa observação abstrair aqueles elementos que são verdadeiramente essenciais no objeto e, posteriormente, conseguir compô-los de modo a formar uma nova qualidade com aqueles mesmos elementos. Esse processo, que é educativo, precisa ser intencionalmente organizado.

Ao dar forma ao que antes não tinha forma, ao procurar dar ao objeto a forma desejada, o artista depara-se com duas necessidades primárias: conhecer ou dominar as leis do objeto que vai trabalhar, bem como os modos de ação possíveis no processo de criação e estabelecer um plano de ação para a criação do objeto, plano esse que irá conter o conhecimento inicial do sujeito sobre o objeto e os modos de ação que já possui, criados em outras situações. Nesse movimento, presente dos primeiros artistas da humanidade aos grandes artistas de nosso tempo, foi-se acumulando diversos conhecimentos sobre o processo de criação de objetos artísticos e que devem ser socializados não apenas como um conjunto de técnicas ou instrumentos, mas, fundamentalmente, como um conjunto de modos de ação especificamente humanos (condutas e capacidades humanas) e que, portanto, devem ser de domínio de todos nós.

Formar o pensamento teórico no campo da arte não é o mesmo e na verdade é bem distinto, que estudar a teoria da arte ou a história biográfica de uma manifestação artística em específico. Defender a formação do pensamento teórico no campo da arte refere-se à defesa de estudo do próprio processo de criação do artista, dos modos de ação para a criação ou apreciação das atividades artísticas que foram sendo criadas ao longo da história da humanidade. Trata-se de estudar e apropriar-se, portanto, dos modos de ação na esfera das atividades artísticas que nos permitem abstrair os elementos da realidade (quais são eles e quais suas propriedades) e sintetizá-los em uma nova realidade (a realidade artística). E essa tarefa é uma tarefa que deve estar presente no trabalho pedagógico da escola.

Em nosso experimento didático, pudemos analisar o movimento de apropriação de determinados conceitos relacionados à criação de cenas circenses por parte dos estudantes que, mesmo não tendo internalizado os conceitos em seus múltiplos aspectos, demonstraram iniciar o movimento de análise e síntese teórica do objeto de estudo. Demonstraram uma mudança de qualidade na forma de “enxergar” a atividade de criação das cenas circenses e no modo de agir nesse processo, tornando-o cada vez mais consciente e voluntário, isto é, subordinado aos fins estabelecidos. Observamos uma mudança de qualidade na relação de 
muitos estudantes com o objeto de estudo, no sentido de terem suas ações com o objeto cada vez menos espontâneas e cada vez mais mediadas pelos conceitos teóricos trabalhados.

Retomados esses pontos da pesquisa, que já nos indicam importantes considerações para pensarmos o objeto de nosso trabalho - o processo de organização do ensino para a formação do pensamento teórico - gostaríamos de aprofundar, neste momento, o que consideramos ser um dos resultados centrais alcançados com a pesquisa: a elaboração da unidade fundamental do objeto de ensino como referência para a elaboração da atividade de ensino.

O experimento didático e as análises decorrentes dele deram-se a partir de uma atividade específica: o circo. Entretanto, o processo de organização da unidade de ensino do circo nos parece permitir analisar um modelo ou modo geral de ação para organizarmos unidades de ensino pautadas no desenvolvimento do pensamento teórico para outras manifestações da cultura corporal e para outras áreas de conhecimento. Determinar a unidade fundamental de um objeto que se queira ensinar (determinar aquilo que o caracteriza de fato ou em essência), explicitar as abstrações conceituais presentes naquele objeto e necessárias de serem aprendidas pelos estudantes e esboçar as ações do educador e as ações dos estudantes no percurso de apropriação do objeto de estudo em questão (de seus conceitos), são comuns a quaisquer objetos de ensino.

Não estamos nos referindo a uma transferência direta entre a unidade didática elaborada para o ensino do circo e outras unidades didáticas. O que estamos considerando é que, a partir desta pesquisa, conseguimos expor (ainda que como esboço) um percurso de ação docente para a organização do ensino que objetive formar o pensamento teórico nos educandos. Percurso esse que explicita um caminho de formação teórica para o próprio educador, que deve dominar conceitualmente o objeto de ensino antes mesmo de iniciar o trabalho pedagógico com os estudantes.

Um objeto de ensino deve ser tomado, em primeiro lugar, como um objeto histórico, que precisa ser compreendido em sua essência e em seu processo histórico de desenvolvimento. Neste sentido é preciso esmiuçar o objeto em questão, analisá-lo em busca de seus elementos constituintes e das relações essenciais entre esses elementos. Tal processo nos leva à explicitação da unidade fundamental do objeto (em nosso caso a composição de cenas circenses). Neste movimento, começamos a elaborar, também, os conceitos ou as abstrações essenciais que nos permitem analisar e/ou materializar o objeto em questão (em nosso caso, os elementos de criação das cenas). A unidade fundamental do objeto, por revelar aquelas características necessárias e suficientes para compreendermos a sua essência, serve 
como um norteador para as ações pedagógicas para o processo de elaboração do ensino. Ter a unidade fundamental de um objeto significa, ao mesmo tempo, ter a síntese conceitual que constitui aquele objeto. É nesta medida que a unidade nos fornece a referência para a elaboração das ações de ensino e das ações de aprendizagem.

A elaboração das ações de ensino nos permite esboçar o percurso real de trabalho docente e discente no processo de apropriação do objeto de estudo, de suas abstrações conceituais e da síntese final. Explicitar essas ações implica em organizar as intervenções dos educadores para que os estudantes estejam em atividade de estudo. A unidade passa a ser o "norte”, o objeto final da aprendizagem, o ponto de chegada do trabalho pedagógico para os estudantes e, por isso, a referência do educador em suas ações.

Como síntese dessas discussões, consideramos que a elaboração e/ou sistematização das unidades fundamentais para cada objeto de ensino, bem como de seus conceitos, podem nos indicar um modo para a elaboração de propostas curriculares, para as diferentes áreas de conhecimento e que busquem organizar o ensino do pensamento teórico. Ressaltamos, aqui, a importância dessa sistematização para a área ou disciplina de educação física, que ainda não possui um conjunto de conhecimentos (empíricos e teóricos) de fato sistematizados e disponíveis em materiais e/ou currículos para sua socialização. Entretanto, entendemos essa necessidade também presente para as demais disciplinas, posto que muitas delas possuem os conceitos empíricos e não os teóricos, como as principais referências e sistematizações do conhecimento escolar (DAVIDOV, 1982).

Imaginamos que essa defesa pela construção de um currículo “universal” e, sobretudo, construído a partir dessas referências - que especificam maximamente os conceitos de ensino e aprendizagem - possa ser recebida com críticas, sob a alegação de ser um modelo curricular “ultrapassado” e que limitaria as ações dos docentes e dos discentes. Pois consideramos justamente o oposto.

Da mesma forma que defendemos, ao longo desta pesquisa, a necessidade de sistematizarmos os conceitos para os estudantes, de modo a fornecermos instrumentos para suas ações com o objeto de estudo, isto é, da mesma forma que defendemos a necessidade de formação teórica dos alunos, defendemos essa mesma necessidade para os educadores. Fornecer sínteses conceituais aos educadores, seja sobre a organização do ensino, seja sobre os conteúdos a serem ensinados (os conceitos essenciais de cada objeto), não constitui uma forma de limitar as ações dos professores, pelo contrário as ampliam. As sínteses conceituais contidas em um currículo devem servir como um instrumento para as ações dos educadores, tanto para a elaboração de suas unidades de ensino, quanto para suas unidades de aula. As 
sínteses conceituais devem contribuir para que os educadores se apropriem da sua atividade principal (a atividade docente) e que organizem a atividade principal dos estudantes (a atividade de estudo) de modo cada vez mais consciente e intencional.

Acreditamos que pudemos demonstrar ao longo deste trabalho, especialmente no processo de ensino e aprendizagem desenvolvido em nosso experimento didático, o que significa trabalhar com a formação do pensamento teórico na educação física. O processo de organização do ensino e as tarefas de aprendizagem com a unidade didática do circo nos parecem possibilitar que professores e pesquisadores generalizem determinados aspectos dessa prática para outras manifestações da cultura corporal: determinar o que é essencial em cada uma das manifestações corporais (encontrar a unidade fundamental em cada uma delas); explicitar os conhecimentos (ou conceitos) necessários de serem ensinados e aprendidos; organizar as tarefas de aprendizagem e as ações que professores e estudantes devem percorrer para se aproximarem do objeto de estudo.

Como vimos ao longo do trabalho, nossos estudantes, a despeito dos muitos momentos de reflexões e discussões coletivas, não deixaram de "praticar" o circo (neste sentido geralmente atribuído à palavra prática e à própria educação física). Entretanto, a prática mesma estava subordinada, por assim dizer, ao movimento geral de apropriação da atividade artística presente no circo, isto é, na apropriação do modo de ação do artista circense, em que o ato de realizar movimentos constitui-se em apenas um momento ou elemento de sua ação.

A Atividade teórica na disciplina de educação física - assim como nas demais disciplinas escolares - constitui-se em uma forma de organizar o processo de apropriação de aspectos da realidade que, via de regra, não são aparentes e, portanto, diretamente acessíveis à maioria dos educandos. A Atividade teórica, portanto, não significa a negação das ações práticas, mas a vinculação destas a um modo específico de ação do pensamento.

Podemos dizer, ao final deste trabalho, que o objeto de ensino e de aprendizagem da educação física seja a atividade que se está estudando, com toda a sua estrutura: motivo, objetivo, ações (mentais e motoras), operações. Para sustentar essa afirmação precisamos desenvolver os seus argumentos.

Em primeiro lugar, ao nos referirmos ao termo "atividade" como objeto de ensino e aprendizagem da disciplina de educação física, estamos nos aproximando do conceito de atividade desenvolvido por Leontiev (1978; 1983) e incorporado nesta pesquisa. Assim, nem todas as manifestações da cultura corporal podem ser tomadas como uma atividade nos termos propostos anteriormente (como uma estrutura) e, portanto, constituírem, em si, em uma "unidade de ensino". O xaxado, a congada, o frevo, a umbigada e o samba, por exemplo, 
não são, em si, atividades. Todas essas manifestações, com suas muitas particularidades, fazem parte da atividade de ensino "Dança”. Ou seja, a "Dança” possui uma unidade fundamental e conceitos essenciais, comuns aos diversos tipos de danças. A Dança representa uma síntese de um modo específico de relação do homem com o mundo na esfera das atividades artísticas; representa a generalização das diversas manifestações particulares da dança. Isto não quer dizer, que ela possa abarcar ou esgotar todas as manifestações corporais de dança (em suas especificidades), mas, sim, que o estudante possa sair desse processo de ensino (realizado com algumas danças específicas), com uma compreensão teórica sobre a atividade de dança, isto é, que possa formar o seu pensamento estético-artístico na dança.

Poderíamos estabelecer a mesma relação para a atividade "Luta” e para a atividade “Jogos” (com as diversas manifestações particulares que as constituem). Ter uma atividade como objeto de ensino significa que essa atividade possua uma unidade fundamental - uma relação essencial - a ser ensinada e aprendida, bem como conceitos mediadores para essa apropriação. Significa que a atividade mesma possa representar uma síntese do processo de desenvolvimento humano em uma determinada esfera da vida.

Em segundo lugar, aos nos referirmos ao termo "atividade” como objeto de ensino e aprendizagem da educação física queremos explicitar, a partir de sua estrutura, que a ação motora constitui-se em um de seus elementos. De certo modo, e historicamente, as ações motoras são aquelas mais evidentes quando se pensa no ensino da educação física e que, para muitos, lhe confere a legitimidade de uma disciplina específica. Entretanto, e utilizando-nos do mesmo método para a compreensão de um fenômeno que buscamos concretizar nessa pesquisa, podemos dizer que os movimentos ou ações motoras não constituem a essência ou “as características necessárias e suficientes” para a compreensão do objeto de ensino da educação física, mas constituem apenas um de seus elementos. Isso tampouco quer dizer que se trate de um elemento sem importância ou mesmo secundário no ensino da educação física, mas somente que não se trata do seu elemento essencial e, assim, no carro-chefe para o processo de organização curricular.

Ao afirmarmos que cabe à educação física o ensino de uma atividade humana (historicamente vinculada à cultura corporal) em toda a sua estrutura, queremos dizer que se trata de ensinar e aprender os diversos modos com que os homens foram criando a atividade em questão e criando-se a si mesmos a partir dessas atividades. Reconhecer o processo de desenvolvimento de uma atividade (sobretudo de um ponto de vista filogenético), significa reconhecer um processo concomitante de desenvolvimento do próprio homem (novas formas de conduta, novas funções psíquicas, novas ações mentais, novas ações motoras). E todo esse 
conjunto de elementos que enriqueceu o homem de características especificamente humanas deve ser apropriado pelas novas gerações. Deve, assim, ser ensinado no trabalho pedagógico escolar.

Comecemos com o exemplo do circo, que foi utilizado nesta pesquisa. Ensinar e aprender sobre o circo nas escolas, nas aulas de educação física, significa ensinar e aprender sobre a atividade circense historicamente criada pelos homens. Isso, como procuramos explicitar e organizar em nosso experimento didático, não significa uma formalização do ensino, isto é, um ensino biográfico do circo, sobre a história do circo. Essa dimensão, de certo, pode estar presente e, inclusive, esteve em alguns momentos de nossas aulas, mas não constituem a essência mesma da atividade circense. Para aprender a atividade em sua estrutura não basta aos estudantes ouvirem, lerem e discutirem sobre a história biográfica de uma manifestação.

Agir como um artista circense não é, portanto, apenas realizar os movimentos motores presentes no circo e/ou declarar a história de sua formação. É realizar ações mentais (análise, síntese, planejamento) relacionadas à criação de uma cena circense. Como um dos elementos dessas ações, estarão as ações motoras com os movimentos específicos do circo. Mas a questão é que o ensino do circo (ou de qualquer outra manifestação) deve permitir que os educandos saiam do processo educativo com muito mais do que um conjunto de "novos movimentos" ou de "novas informações sobre o circo". Deve permitir que eles saiam com novos modos de ação e, finalmente, com uma nova forma de pensar aquela realidade ou a partir daquela realidade estudada.

Da mesma forma, agir como um jogador de esportes ou um lutador não resulta em sair do processo de ensino com um conjunto bem dominado de movimentos e de regras dos esportes/lutas trabalhados, mas sair com um novo modo de pensar: pensar como um jogador/lutador, adquirir as ações mentais (ou algumas delas) que são inerentes aos jogos coletivos e as lutas. Nesse processo, estaria a formação do pensamento lúdico-estratégico, uma manifestação do pensamento teórico no campo dos jogos e atividades lúdicas.

Diante das reflexões que apresentamos e que buscaram sintetizar o movimento conceitual de nossa pesquisa, indicamos três desdobramentos ou tarefas futuras: a) uma sistematização dos princípios didáticos existentes na teoria histórico-cultural, de modo a abarcar os principais conceitos desenvolvidos por seus autores e de modo a nos ajudar a pensar sobre a educação em geral e o ensino escolar em particular; b) elaborar um modo de ação docente que especifique os percursos do educador e dos educandos no trabalho pedagógico, ressaltando para ambos (e dentro de suas especificidades) a relação com o 
conhecimento teórico; c) sistematizar os conceitos teóricos fundamentais presentes no ensino da educação física, esboçando as ações docentes e discentes com esses conhecimentos (elaborar uma proposta curricular para essa disciplina).

Por fim, e como sujeitos do processo de realização da pesquisa, passaremos a uma breve análise sobre o nosso percurso de formação ao longo deste trabalho.

No decorrer de nossas análises tecemos algumas criticas sobre o ensino efetivamente realizado por nós em virtude de seu distanciamento do ensino elaborado ou considerado ideal para a formação do pensamento estético-artístico dos educandos. Por um lado, trata-se das condições objetivas da pesquisa e que perpassam as salas de aulas no cotidiano de nossas escolas: tempo disponível para trabalhar com as crianças; caráter inicial do movimento de apropriação do pensamento teórico pelas mesmas; existência de inesperados durante a prática de ensino. Por outro lado, trata-se, também, da existência de uma dimensão “idealista” em nossas ações como professora e que, certamente, manifestam-se em nossas ações como pesquisadora; trata-se de um “desejo inconsciente” de querermos obter resultados na realidade, com nossas ações reais, que sejam “iguais” aos resultados planejados idealmente. É certo, como diz Gramsci, que a "possibilidade não é a realidade, mas é também ela uma realidade”, mas conseguir perceber a realidade possível em um dado momento e em dadas condições ainda é, para nós, uma tarefa a ser melhor aprendida. É preciso, certamente, querer que a possibilidade se transforme em realidade efetiva, mas é preciso saber, também, que às vezes e em dado momento, essa transformação não pode se dar, ao menos não de forma completa. Assim, devemos reconhecer que nosso experimento didático e a despeito de nossas críticas, efetivamente conseguiu esboçar um ensino organizado para a formação do pensamento teórico.

Avaliamos, também, que nós mesmos passamos por um movimento de apropriação conceitual ao longo dessa pesquisa. A compreensão de alguns conceitos deu-se de modo muito mais amplo na medida em que tivemos que agir com tais conceitos, tanto nas ações de planejamento da unidade didática, quanto e principalmente, nas ações de análise dos dados. Vemos, então, que alguns conceitos da psicologia histórico-cultural ampliaram e modificaram qualitativamente nossas ações, o que indica que foram, ou estão sendo, de fato, internalizados. O modo geral de ação docente proposto foi ele mesmo vivenciado por nós como professores (organizadores da unidade didática e atuantes com as crianças) e pesquisadores (analisando o processo de elaboração do plano e as ações docentes e discentes realizadas). Assim, conceitos como: modo geral de ação, pensamento teórico, conceito, essência e aparência, internalização, zona de desenvolvimento próximo e atividade de estudo, puderam ser 
vivificados pela pesquisa e, assim, compreendidos não só como uma abstração (seu significado conceitual ou definição), mas em sua concreticidade (como um modo geral de ação do docente e do pesquisador). Do mesmo modo que buscamos formar ações generalizadas nos educandos, como produto de sua apropriação dos conhecimentos escolares, devemos formar ao final de uma pesquisa ações generalizadas sobre a própria atividade de pesquisa. Devemos sair desse processo, que é educativo por essência, nós mesmos modificados. 


\section{REFERÊNCIAS BIBLIOGRÁFICAS}

ASBAHR, F. da. S. F. Sentido pessoal e projeto político pedagógico: análise da atividade pedagógica a partir da Psicologia Histórico-Cultural. 2005. 199f. Dissertação (Mestrado em Psicologia)- Instituto de Psicologia, Universidade de São Paulo, São Paulo, 2005.

BERNARDES, M. As ações na atividade educativa. 2000. Dissertação (Mestrado em Educação)-Faculdade de Educação, Universidade de São Paulo, São Paulo, 2000.

CEDRO, W. O espaço de aprendizagem e a atividade ensino: O Clube de Matemática. 2004. Dissertação (Mestrado em Educação)- Faculdade de Educação, Universidade de São Paulo, São Paulo, 2004 .

O motivo e a atividade de aprendizagem do professor de Matemática: uma perspectiva histórico-cultural. 2008. f. Tese (Doutorado em Educação)- Faculdade de Educação, Universidade de São Paulo, São Paulo, 2008.

COLETIVO DE AUTORES. Metodologia do ensino da educação física. São Paulo: Cortez. 1992

DAVIDOV, V. Análises de los principios didáticos de la escuela tradicional y posibles principios de enseñanza en el futuro proximo. In: DAVIDOV, V.; SHUARE, M. La psicología evolutiva y pedagógica en la URSS: antología. Moscou: Editorial Progreso, 1987.

La ensenanza escolar y el desarrollo psiquico: investigación psicológica teórica y experimental. Moscou: Editorial progresso, 1988.

DAVIDOV. V.; MÁRKOVA, A. La concepción de la actividad de estudio de los escolares. In: DAVIDOV, V.; SHUARE, M. La psicología evolutiva y pedagógica en la URSS: antología. Moscou: Editorial Progreso, 1987. 
DAVYDOV, V. V. Tipos de generalización en la enseñanza. Havana: Pueblo y Educación, 1982.

DIAS, M. S. Formação da imagem conceitual da reta real: um estudo do desenvolvimento do conceito na perspectiva lógico - histórica. 2007. f Tese (Doutorado em Educação)- Faculdade de Educação, Universidade de São Paulo, São Paulo, 2007.

DUARTE, N. A individualidade para-si: contribuição a uma teoria histórico-social da formação do indivíduo. Campinas: Autores Associados, 1993.

A escola de Vigotski e a educação escolar: algumas hipóteses para uma leitura pedagógica da psicologia histórico-cultural. Revista Psicologia USP, São Paulo, v.7, n.1/2, p.17-50, 1996.

ELKONIN, D.B. Psicologia do Jogo. São Paulo: Martins Fontes, 1998.

FISCHER, E. A necessidade da Arte. Rio de Janeiro: Zahar, 1976.

FRIGOTTO, G. A produtividade da escola improdutiva: um (re) exame das relações entre a educação e a estrutura econômico social capitalista. São Paulo: Cortez, 2001.

GALPERIN, P. Sobre la investigación del desarrollo intelectual del niño. In: DAVIDOV, V.; SHUARE, M. La psicología evolutiva y pedagógica en la URSS: antología. Moscou: Editorial Progreso, 1987.

GALPERIN, P; ZAPORÓZHETS, A; ELKONIN, D. Los problemas de la formación de conocimientos y capacidades en los escolares y los nuevos métodos de enseñanza en la escuela. In: DAVIDOV, V.; SHUARE, M. La psicología evolutiva y pedagógica en la URSS: antología. Moscou: Editorial Progreso, 1987.

GASPARIN, J. L. Uma didática para a pedagogia histórico-crítica. Campinas, SP: Autores Associados, 2002. 
HELLER, A. Sociologia de la vida cotidiana. Barcelona: Península, 1991. . O Cotidiano e a História. 6 $6^{\text {a }}$ ed. Rio de Janeiro: Paz e Terra, 2000.

KOPNIN, P. V. A dialética como lógica e teoria do conhecimento. Rio de Janeiro: Civilização Brasileira, 1978.

KOSIK, K. Dialética do Concreto. 7ª edição. Rio de Janeiro: Paz e Terra, 2002.

LEONTIEV, A. N. O desenvolvimento do Psiquismo. Lisboa: Livros Horizontes, 1978. . Actividad, conciencia y personalidad. Havana: Pueblo y educacion, 1983 - Uma contribuição à teoria do desenvolvimento da psique infantil. In: VIGOTSKII, L. S; LURIA, A. R; LEONTIEV, A. N. Linguagem, desenvolvimento e aprendizagem. São Paulo: ICONE, 1991.

LURIA, A. R. Desenvolvimento cognitivo: seus fundamentos culturais e sociais. São Paulo: Ícone, 2005.

MARX, K; ENGELS, F. Sobre literatura e arte. São Paulo: Global, 1980.

MARX, K. Manuscritos econômico-filosóficos. São Paulo: Boitempo, 2004. A Ideologia Alemã. São Paulo: Hucitec. 1996.

MAUSS, M. Sociologia e antropologia. São Paulo: EDUSP, 1974.

MÉSZÁROS, I. A educação para além do capital. São Paulo: Boitempo, 2005 
MORETTI, V. D. Professores de matemática em atividade de ensino. Uma perspectiva histórico-cultural para a formação docente. 2007. 202 f. Tese (Doutorado em Educação)Faculdade de Educação, Universidade de São Paulo, São Paulo, 2007.

MOURA, M. O. Construção do signo numérico em situação de ensino. 1992. Tese (Doutorado em Educação)-Faculdade de Educação, Universidade de São Paulo, 1992.

. A atividade de ensino como unidade formadora. Bolema, São Paulo, ano II, n.12, p.29-43, 1996.

. A atividade de ensino como ação formadora. In: CASTRO, A.; CARVALHO,

A. (org.). Ensinar a ensinar: didática para a escola. São Paulo: Editora Pioneira, 2001.

Pesquisa colaborativa: um foco na ação formadora. In: Barbosa, Raquel Lazzari Leite (org). Trajetórias e perspectivas da formação de educadores. São Paulo: Editora Unesp, 2004. p. 257-284

MOURA, M. O. et al. Atividade orientadora de ensino: unidade entre ensino e aprendizagem. Diálogo educacional, Curitiba, n. 29, p 205-229, 2010.

NASCIMENTO, C. P. A psicologia histórico-cultural e o desenvolvimento infantil: reflexões a partir da e para a prática da educação física infantil. Monografia - Escola de Educação Física e Esporte - Universidade de São Paulo, 2004.

. O desenvolvimento histórico-cultural da criança nas aulas de educação física: possibilidades de trabalho a partir da atividade principal e dos temas. Revista Brasileira de Ciências do Esporte, Campinas, v.31, n.1, p.147-161, setembro de 2009

NUNEZ, I. B. Vygotsky, Leontiev, Galperin: formação de conceitos e princípios didáticos. Brasília: Líber livro, 2009.

OLIVEIRA, B. A dialética do singular-particular-universal. In ABRANTES, A, et al.(org.) Método Histórico Social na Psicologia Social. Petrópolis: Vozes, 2005. 
PANOSSIAN, M. L Manifestações do pensamento e da linguagem algébrica de estudantes: indicadores para a organização do ensino. 2008. Dissertação (Mestrado em Educação)- Faculdade de Educação, Universidade de São Paulo, São Paulo, 2008 .

PLEKHANOV, G. Cartas sem endereço. São Paulo: brasiliense, 1965.

RUBTSOV, V. A atividade de aprendizado e os problemas referentes à formação do pensamento teórico dos escolares. In: GARNIER, C. et al. (org.). Após Vygotsky e Piaget: perspectiva social e construtivista. Escola russa e ocidental. Tradução Eunice Gruman. Porto Alegre: Artes Médicas, 1996.

SAVIANI, D. Pedagogia histórico-crítica primeiras aproximações. Campinas: Autores Associados, 1995.

. Escola e democracia. Campinas: Autores associados, 1997.

SFORNI, M. S. F. Aprendizagem conceitual e organização do ensino: contribuições da teoria da atividade. 2003. Tese (Doutorado em Educação)- Faculdade de Educação, Universidade de São Paulo, São Paulo, 2003.

SHUARE, M. La Psicologia Soviética tal como yo la veo. Moscou: Progresso, 1990.

TALÍZENA, N. Psicologia de la enseñanza. Moscou: Editorial Progresso, 1988.

VAZQUEZ, A. S. As idéias estéticas de Marx. Rio de Janeiro: Paz e Terra, 1968.

VIGOTSKI, L. S. Psicologia da arte. São Paulo: Martins Fontes, 2001. A construção do pensamento e da linguagem. São Pualo: Martins Fontes, 2009. 
VIGOTSKII, L. S. Aprendizagem e desenvolvimento intelectual na idade escolar. In: VIGOTSKII, L. S; LURIA, A. R; LEONTIEV, A. N. Linguagem, desenvolvimento e aprendizagem. São Paulo: ICONE, 1991.

VIGOTSKY, L. S. Imaginación y creación em la edad infantil. Havana: Pueblo y Educacion, 2004.

VYGOTSKI, L. S. Obras Escogidas, tomo III. Madri: Visor, 1995. . Obras Escogidas, tomo IV. Madri: Visor, 1996. Obras Escogidas, tomo V. Madri: Visor, 1997.

VYGOTSKY, L. S; LURIA, A. R. Estudo sobre a história do comportamento: o macaco, o primitivo e a criança. Porto Alegre: Artes medicas, 1996.

WACHOWICS, L. A. O método dialético na didática. Campinas: Papirus, 1991.

ZAPOROZHETS, A.V. Estudio Psicologico del desarrollo de la motricidad en el niño preescolar. In: DAVIDOV, V.; SHUARE, M. La psicología evolutiva y pedagógica en la URSS: antología. Moscou: Editorial Progreso, 1987. 
ANEXOS 
ANEXO I: FICHA ORIENTADORA PARA ELABORAÇÃO DA APRESENTAÇÃO

PERSONAGEM:

\begin{tabular}{|l|l|l|}
\hline ELEMENTOS & SIMBOLO & DESCRIÇÃO \\
\hline INTENÇÃO DA & & \\
APRESENTAÇÃO & & \\
\hline MOVIMENTOS & & \\
\hline COREOGRAFIA & & \\
\hline ÂNGULO DE & & \\
VISÃO & & \\
\hline
\end{tabular}

DESENVOLVIMENTO DA CENA (início, meio e fim): 
ANEXO II:

FICHA ORIENTADORA - PERSONAGEM: EQUILIBRISTA

\section{FICHA ORIENTADORA PARA ELABORAÇÃO DA APRESENTAÇÃO}

PERSONAGEM: EQU IL:BR:S A

DESENVOLVIMENTO DA CENA (início, meio e fim):

1 Ricardo IDIABOLO com FACAM ELFUADORE IRQMINA ḊOGANAQPAR

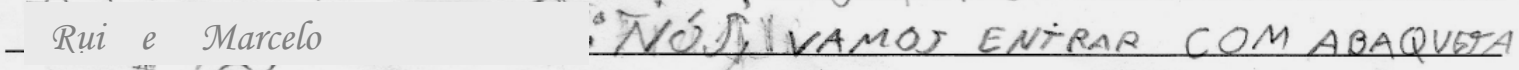
SEMLORAA POR DENTRO DO CASACO EM UM BOLSO INTERNO EA OURRA BAQUETA COMORDA LEVANDO ODABOLO PAR UMA VOLAA NODIABOLO EFINGIA QUE VAT JOGAR; EDEPOIS NÓS FIMOS OLHAMOS PARAC OPCÉU E OLHAMOS PARA O CHĂQ E O DIABOLO ESTA LA' Ai NÓ APRENDEMOS A JOGAR AI AGENTE JOGA EQUANOO PEGA TROPEGA E CAI. Luiz Eu comeno jogando ar bolar pora ol a

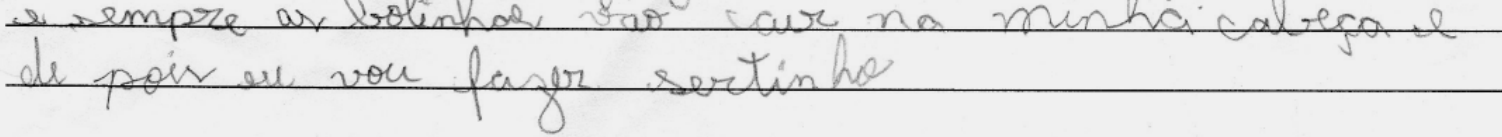

\begin{tabular}{|c|c|}
\hline ELEMENTOS & DESCRIÇÃO \\
\hline MOVIMENTOS & $M A L A B A R: S T A$ \\
\hline COREOGRAFIA & 1) Ricardo, 2) Rui e Marcelo, 3) Luiz \\
\hline NARRADOR & Rui \\
\hline ACESSÓRIOS & DiABOLOX3 CORDE hGUECRERRA \\
\hline MÚSICA & BON:TAFENGAASSAOA \\
\hline ÂNGULO DE VISÃO & $R F ?$ \\
\hline
\end{tabular}


ANEXO III:

FICHA ORIENTADORA - PERSONAGEM: ACROBATA + CONTORCIONISTA

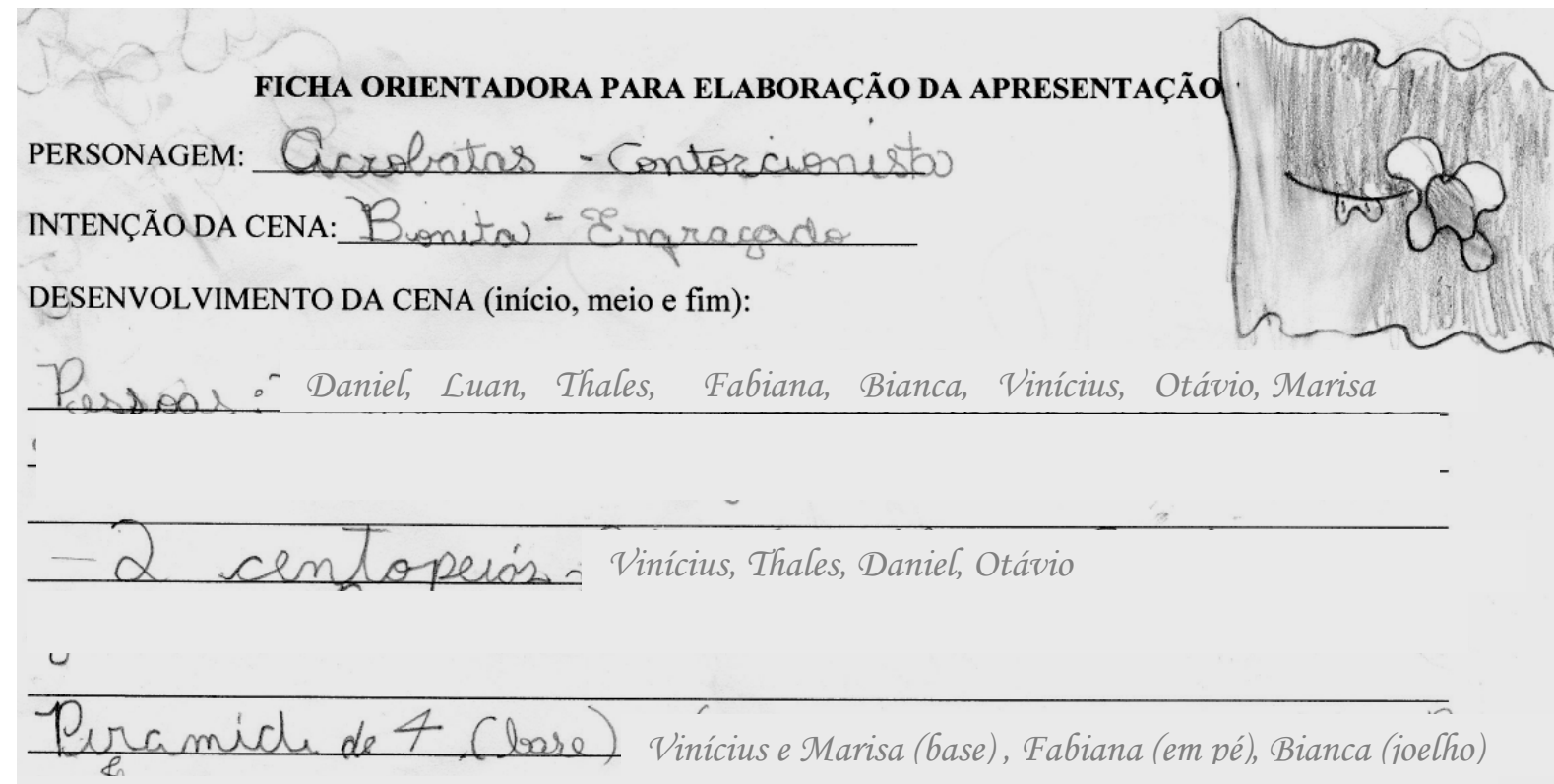

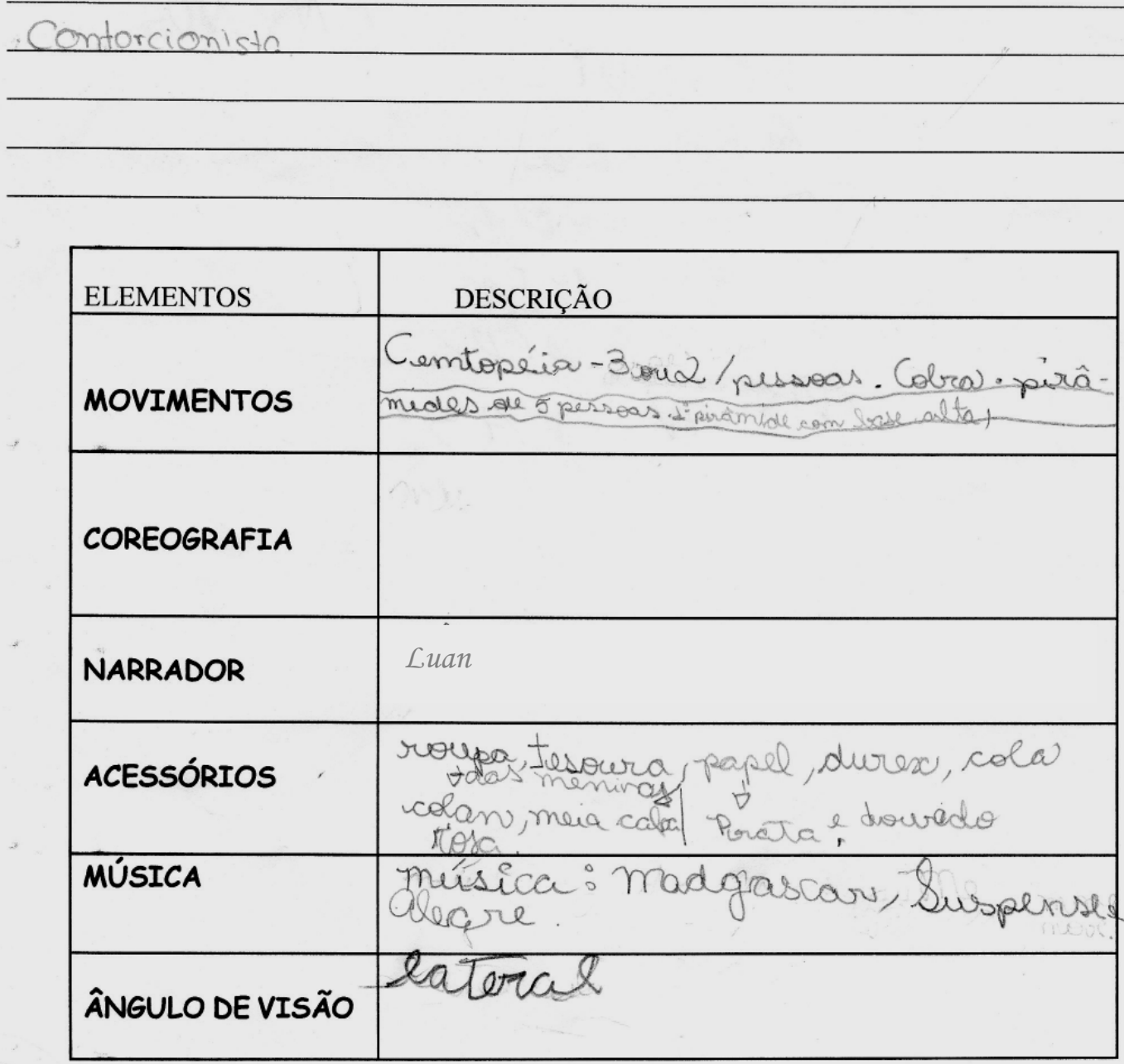


ANEXO IV

FICHA ORIENTADORA - PERSONAGEM: MÁGICO

\section{FICHA ORIENTADORA PARA ELABORAÇÃO DA APRESENTAÇÃO}

PERSONAGEM: Magice

INTENÇÃO DA CENA:Colimiracã̃o

DESENVOLVIMENTO DA CENA (início, meio e fim):

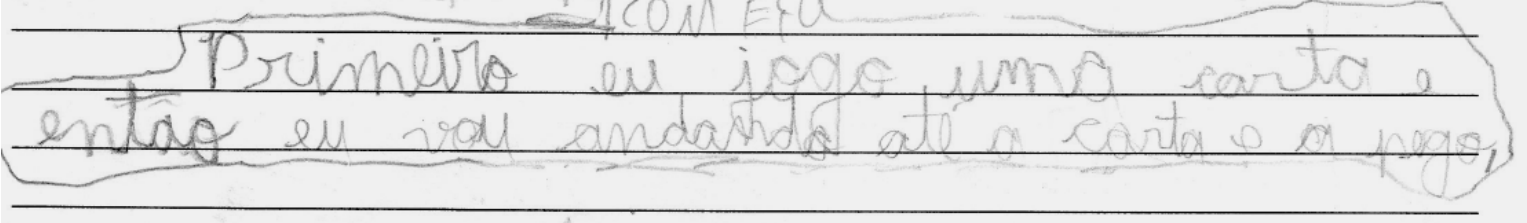

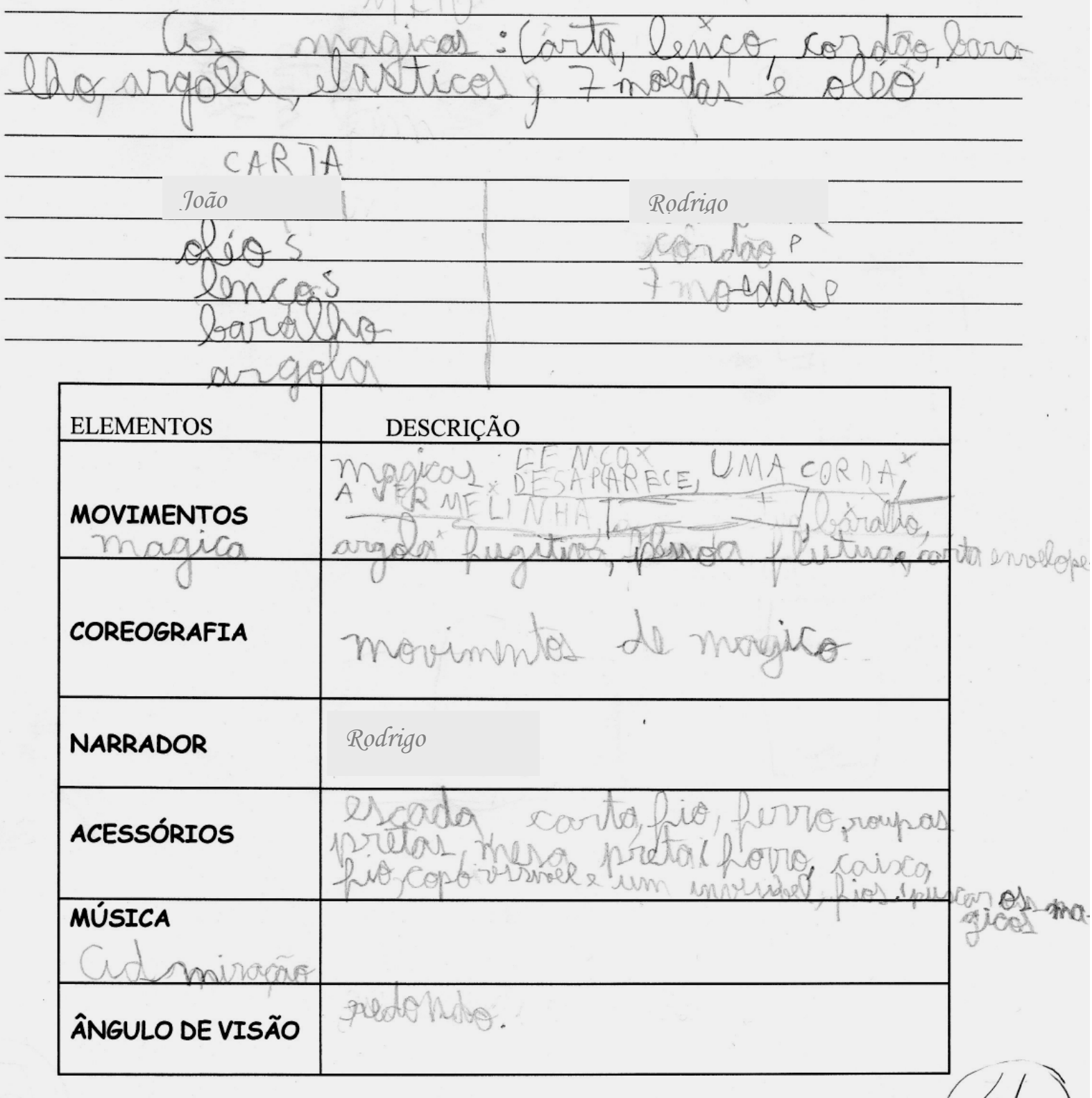


ANEXO V: elementos conceituais apresentados às crianças

ELEMENTOS PARA

A ORGANIZAÇÃO

DAS CENAS E SEUS

CONCEITOS

\section{INTENÇÃO: \\ SUSPENSE}

Criar momentos de tensão para o público (demonstrar uma falsa insegurança ou apreensão, quando na verdade 0 personagem domina a situação).

\section{MOVIMENTOS :}

Os movimentos que serão realizados.

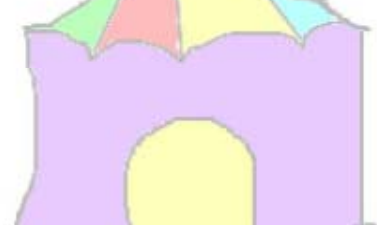

INTENÇÃO:

\section{ENGRAÇADA}

Criar cenas intencionalmente erradas (errar os elementos que compõem as cenas circenses); fazer papel de bobo;

\section{INTENÇÃO: \\ BELA}

Dar a impressão de perfeição na cena (harmonia, ritmo).

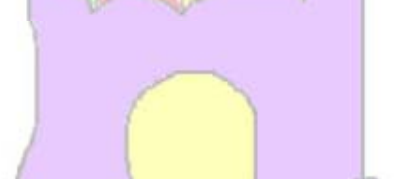

\section{COREOGRAFIA:}

Modo de organização das ações dos personagens (a seqüência dos movimentos, a duração de cada cena, a organização no espaço). 


\section{ÂNGULO DE VISÃO:}

Colocar em evidência o objeto que se quer mostrar para o público. Permitir que o publico tenha a melhor visão possível da cena que se construiu.

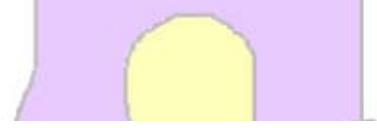

\section{COREOGRAFIA:}

Modo de organização das ações dos personagens (a seqüência dos movimentos, a duração de cada cena, a organização no espaço).

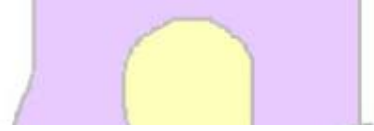

\section{NARRADOR:}

Busca instigar a relação do público com a cena. Pode se dar através da figura de um narrador ou pelos próprios personagens.

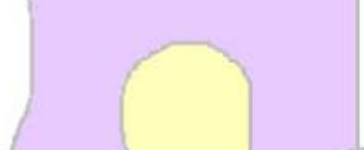

\section{ACESSÓRIOS:}

Roupas, cenários, maquiagens que buscam confirma a intenção pretendida com a cena.

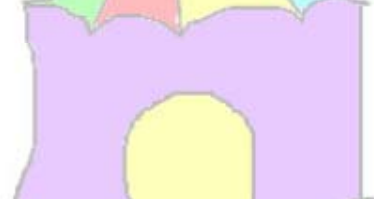

MÚSICA:

Trilha sonora que contribui para o ritmo e o desenvolvimento das intenções pretendidas com a cena.

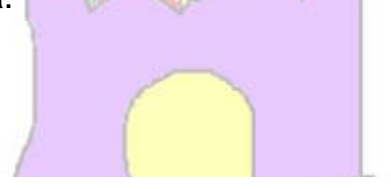

